\title{
Um Só Currículo: Actividades para uma Educação Integrada em Sexualidade, Género, HIV e Direitos Humanos
}

International Sexuality and HIV Curriculum Working Group

Nicole Haberland

Population Council

Deborah Rogow

Follow this and additional works at: https://knowledgecommons.popcouncil.org/departments_sbsr-pgy

Part of the Demography, Population, and Ecology Commons, Family, Life Course, and Society Commons, Gender and Sexuality Commons, International Public Health Commons, and the Medicine and Health Commons How does access to this work benefit you? Let us know!

\section{Recommended Citation}

International Sexuality and HIV Curriculum Working Group. 2015. "Um Só Currículo: Actividades para uma Educação Integrada em Sexualidade, Género, HIV e Direitos Humanos," edited by Nicole Haberland and Deborah Rogow. New York: Population Council. 


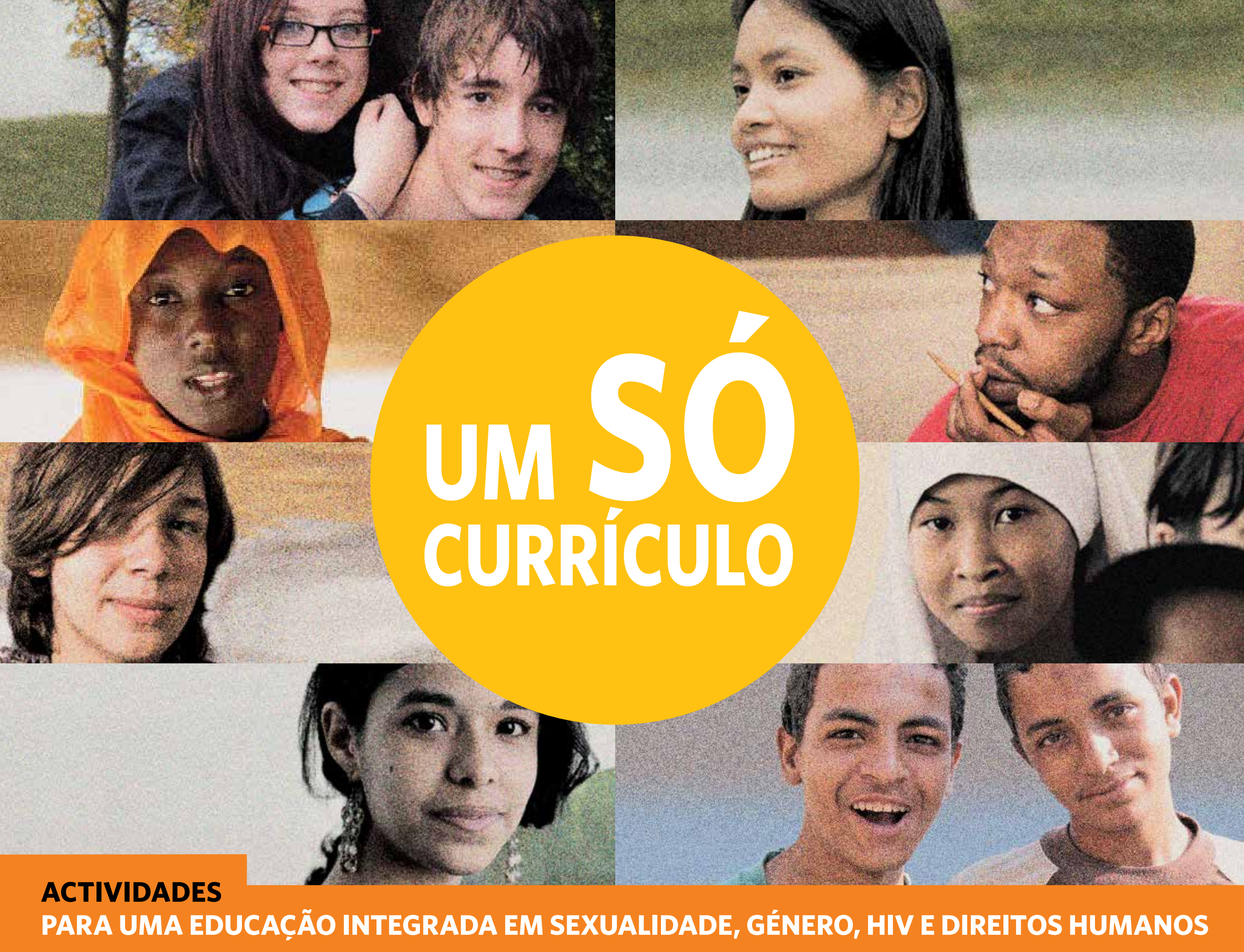




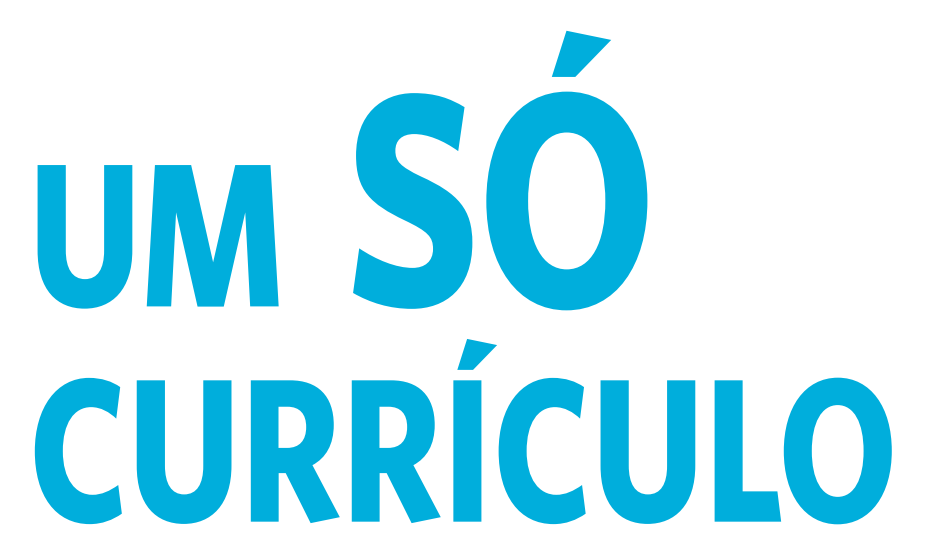

ACTIVIDADES PARA UMA EDUCAÇÃO INTEGRADA EM SEXUALIDADE, GÉNERO, HIV E DIREITOS HUMANOS 


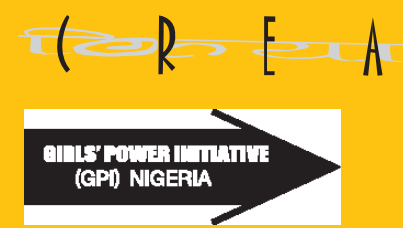

\section{GIPPF $=$}

\section{GIPPF}

Wertem Henisphere Region

INTERNATIONAL WOMEN'S
HEALTH COALITION

\section{Mexfam \\ Salud para tu familia}

1 Population Council
Um Só Currículo: Directrizes e Actividades para uma Educação Integrada emSexualidade, Género, HIV e Direitos Humanos é um documento que foi elaborado por um grupo de trabalho internacional constituído por representantes das seguintes organizações (por ordem alfabética):

CREA (India): Caroline Earle, Sunita Kujur, Geeta Misra

Girls Power Initiative (Nigéria): Bene Madunagu, Grace Osakue

International Planned Parenthood Federation (IPPF): Doortje Braeken

IPPF/Western Hemisphere Region: Jessie Clyde, Denise Kohn

International Women's Health Coalition (IWHC): Kelly Castagnaro, Corinne Whitaker

Mexfam (México): Ofelia Aguilar

Population Council: Nicole Haberland, Deborah Rogow

O grupo de trabalho trouxe um leque de perspectivas e conhecimentos técnicos relevantes para a educação em sexualidade na adolescência / HIV, incluindo em áreas de direitos e género, gestão de programas, pesquisa e advocacia. Andrea Irvin também ajudou a elaborar uma série de secções. A traducão para o português foi realizada em coordenacão com o UNFPA/Moçambique. A produção deste volume (ACTIVIDADES) foi realizada em coordenação com o IPPF/Região Africana e IPPF/WHR.

\section{Escrito pelo International Sexuality and HIV Curriculum Working Group Editado por Nicole Haberland e Deborah Rogow}

\section{Tradução: Judite Baloi}

Coordenadores do Projecto: Michelle Skaer, Jonah Stuart Brundage, e Amy Handler Design: Emanuela Frigerio, Hyun Auh, C\&G Partners, New York City

Produção: Christina Tse, Edgar Peralta

Créditos das fotos das imagens de capa (no sentido dos ponteiros do relógio, do canto superior esquerdo): Maura Carroll: Ronn Aldaman; Eugene Martin; Manoocher Ceghati, cortesia de IRIN; Melissa May; Gabe Cooney, cortesia do IPPF/WHR; Michael Newman; Neil Thomas, cortesia de IRIN. Créditos das fotos das extensões da capa: Effective Teaching Methods, Mark Tuschman, cortesia do FNUAP Guatemala; Activities, Andrea Lynch, cortesia de EMpower e CASA Mexico; Recursos Adicionais, Amy Joyce. Todos os demais créditos da foto são identificados ao lado da imagem.

Publicado pelo Population Council, New York.

Disponível para download gratuito em: www.itsallone.org

Copyright (c) 2019 The Population Council, Inc. Primeira edição revista (inglês), imprimido em 2011.

Qualquer parte deste volume pode ser fotocopiada sem a permissão dos autores ou do editor, desde que seja apontada a autoria da publicação e exemplares sejam distribuídos gratuitamente. Qualquer reprodução comercial requer permissão prévia por escrito do Population Council. Favor anotar também quaisquer fontes originais registadas para actividades seleccionadas.

ISBN: Directrizes: 978-0-87834-117-7; Actividades: 978-0-87834-118-4; Pacote: 978-0-87834-119-1 


\section{índice}

MÉTODOS DE ENSINO EFICAZES

ACTIVIDADES

A SAÚDE SEXUAL E O BEM-ESTAR EXIGEM DIREITOS HUMANOS

actividades 1-4

GÉNERO

actividades 5-16

SEXUALIDADE

actividades $17-26$

RELAC̣ÕES INTERPESSOAIS

actividades $27-33$

HABILIDADES DE COMUNICAC̣ÃO E DE TOMADA DE DECISÕES

actividades 34-39

O CORPO, A PUBERDADE E A REPRODUÇÃO

actividades 40-45

SAÚDE SEXUAL E REPRODUTIVA

actividades $46-52$

ADVOCACIA DA SAÚDE E DIREITOS SEXUAIS E DA IGUALDADE DE GÉNERO

actividades 53-54

RECURSOS ADICIONAIS
1

179

Um Só Currículo consiste em dois volumes. O primeiro volume (DIRECTRIZES) contém uma introdução, 8 unidades de conteúdo e 22 fichas técnicas. Este livro, ACTIVIDADES, é o volume de actividades. 


\section{MÉTODOS}

DE ENSINC

EFICAZES 


\section{uma nota para os educadores e responsáveis pelo desenvolvimento de programas}

É tão importante que informação é ensinada quanto como a ensinamos. Os métodos mais eficazes de ensino da sexualidade, HIV, género e direitos humanos são os métodos educacionais participativos centrados no aluno. ${ }^{\star}$ Com efeito, tais métodos ajudam a preparar os jovens para a vida - e a promover a sua saúde e felicidade — num mundo complexo e em mudança.

Para poderem aplicar métodos de ensino participativos com facilidade e mestria, os educadores necessitam de preparação e de apoio. Esta secção apresenta uma visão geral dos princípios básicos do ensino interactivo centrado no aluno. Também oferece dicas concretas para a aplicação destes métodos especificamente aos currículos sobre a sexualidade e o HIV. Por último, inclui orientações importantes sobre como pôr em prática estes programas no contexto escolar e comunitário. ${ }^{1}$

Um Só Currículo é um conjunto constituído por dois livros. Este livro (ACTIVIDADES) inclui um banco de 54 exemplos de actividades envolventes na sala de aula. O primer livro (DIRECTRIZES) ofrece uma base teórica para os educadores, e algumas também apoia a utilização de métodos de ensino participativos e centrados no aluno. Por exemplo, as unidades de conteúdo contidas nas DIRECTRIZES incluem "Pontos de Reflexão" ocasionais que incentivam o pensamento crítico sobre tópicos seleccionados e a Unidade 8 envolve os alunos em experiências práticas de ensino. 


\section{fundamentação dos métodos de ensino interactivos e centrados no aluno}

A educação não é um processo de absorção passiva. Antes pelo contrário, as pessoas reúnem informação continuamente e reinterpretam o que aprendem com base no seu próprio conhecimento e experiência. Para fazer com que este processo resulte tanto quanto possível, os educadores envolvem os alunos na sua própria aprendizagem.*

Com efeito, muitos pesquisadores concluem que os métodos de ensino interactivos e centrados no aluno produzem melhores resultados que outros métodos educacionais. ${ }^{2}$ Tais métodos apelam aos alunos e promovem o pensamento crítico. ${ }^{3}$ Particularmente no caso dos tópicos que afectam directamente a vida dos alunos, estas abordagens ajudam-nos a personalizar a informação e a praticar novas habilidades. ${ }^{4}$

Ao longo dos anos, as abordagens do ensino participativo tornaram-se o pilar de muitos programas de educação sobre a sexualidade e o HIV. Um número cada vez maior de educadores están aplicando estes métodos dinâmicos e a acrescentar projectos "práticos" numa variedade de áreas temáticas — incluindo estudos sociais, educação cívica, ciências e literatura. Eles constataram que a participação e a livre expressão na sala de aula também incentivam atitudes democráticas. Com efeito, de acordo com um inquérito efectuado em vários países, os alunos que aprendem em ambientes de sala de aula abertos desta natureza revelam um maior apoio à igualdade de género. ${ }^{5}$ Por último, os educadores indicam que, eles próprios, estão a aprender muito ensinando desta maneira.

\section{O QUE É O ENSINO INTERACTIVO CENTRADO NO ALUNO?}

$O$ ensino interactivo centrado no aluno implica uma série de princípios e boas práticas que estão interligados e que envolvem activamente os alunos no seu próprio processo de aprendizagem.

Estes princípios e práticas, descritos nas próximas páginas, destacam: 0 ambiente de aprendizagem; métodos de ensino; habilidades de pensamento crítico; e ajudam os alunos a estabelecer uma ligação entre o que aprendem e as suas vidas.

Vários nomes são utilizados para o ensino interactivo e centrado no aluno. É muitas vezes chamado (ou considerado semelhante à) o ensino participativo, experimental ou prático
* Porque a educação sobre a sexualidade e o HIV é oferecida nas escolas, por grupos comunitários e noutros contextos, os termos "estudante," "aluno" e "participante" são usados de forma indistinta neste livro. 


\section{NOTAS ESPECIAIS PARA O ENSINO SOBRE DIREITOS, GÉNERO, SEXUALIDADE, HIV E SAÚDE SEXUAL:}

Os alunos podem sentir-se pouco à vontade devido à natureza sensível do tópico, ou por causa da sua história ou situação familiar. Planifique como evitar um desconforto desnecessário.

Os alunos podem falar-lhe sobre a gravidez não planejada, experiências de violência, ou outros problemas pessoais ou familiares. Pense em como apoiá-los, mantendo os limites adequados. Infórme-se y difunda entre los participantes, informação sobre programas / serviços locais (por exemplo, um local seguro para jovens sem abrigo ou serviços destinados a mulheres que tenham sido vítimas de abuso). Nos casos de abuso ou de situacões de perigo, esteja ciente dos requisitos necessários para notificar as autoridades.

Pense no seu próprio nível de conforto com o material e, se for necessário, procure obter apoio e conselhos.

Um Só Currículo apoia os valores de igualdade, respeito e direitos humanos. Pense sobre os seus próprios valores pessoais ou religiosos para se certificar de que se sente à vontade para honrar os valores do programa quando se aplicam ao género e à sexualidade.

\section{princípios do ensino interactivo centrado no aluno}

\section{Crie um ambiente de aprendizagem com base na igualdade, respeito e direitos humanos.}

- Crie um ambiente de aprendizagem favorável. Todos os alunos devem sentir-se envolvidos, ouvidos, à vontade e certos de que não serão ridicularizados, em especial quando assumem riscos com novas ideias. Incentive a participação, particularmente nos que se sentem sós ou intimidados. (Várias condições e situações podem desencadear tais sentimentos. Por exemplo, as diferenças de poder social associadas ao género, classe social, ou idade podem ser um factor. Os alunos com fluência limitada na língua falada na escola podem evitar participar nas discussões. Os alunos que são portadores de deficiência física e os que têm outras necessidades especiais podem sentir-se acanhados). Pode incentivar o envolvimento da turma usando actividades que promovam o respeito e o trabalho de equipa e divulgando oportunidades de liderança. Claro que é também importante garantir a segurança e a privacidade do espaço físico.

- Durante a primeira sessão, peça aos alunos que trabalhem em conjunto para desenvolver uma lista de directrizes para a cooperação , para assegurar a harmonia na sua sala de aula. ${ }^{6}$

- Peça aos alunos que respeitem a privacidade das outras pessoas e lembre-lhes que não devem revelar informação a outros que achem que deve ser mantida em sigilo. Considere como alguns alunos podem intimidar ou até abusar os outros depois de saírem de uma aula em que tenham sido discutidos tópicos sensíveis. ${ }^{7}$ Garanta aos seus alunos que você, na qualidade de seu professor, manterá todas as discussões em sigilo. Desta forma, você serve de modelo de respeito da privacidade dos outros. ${ }^{8}$

- Procure certificar-se de que os alunos entendem que têm o direito de não participar ou partilhar, se tal os deixa pouco à vontade.

- Incentive todos os alunos a partilhar os seus pensamentos. Não julgue as suas ideias. 
2 Incentive um processo em que se recorra às experiências dos alunos, integrando nova informação e ideias naquilo que eles já saibam e pensem sobre um tópico.

- Lembre-se que todos os participantes têm conhecimentos e experiência. Oiça e faça perguntas para sacar esses conhecimentos e experiência.

- Oiça as preocupações dos alunos e coloque problemas hipotéticos que reflictam as suas vidas reais. Envolva-os na resolução destes problemas para que façam as suas próprias escolhas e desenvolvam as suas ideias nesse percurso.

- Incentive os alunos a explorar o significado de uma determinada questão nas suas próprias vidas.

- Pense no seu papel como facilitador da discussão das ideias dos alunos, e não como um palestrante ou de alguém que se limita a transmitir informação. Por vezes poderá ter que corrigir erros factuais dos alunos, ou ajudá-los a reconhecer quando um comentário é desrespeitoso.

- Ocasionalmente, poderá apresentar um exemplo da sua própria experiência que seja relevante para a aula. No entanto, seja extremamente cauteloso para manter limites apropriados com os seus alunos

\section{Utilize um leque variado de estratégias para envolver os alunos.}

- Desenvolva uma variedade de métodos e abordagens que possa adaptar às necessidades de aprendizagem dos seus alunos. $^{9}$ [Ver as páginas 8-9 sobre Métodos de Ensino Interactivo.]

- Se estiver a utilizar um plano de aula ou de actividades que seja novo para si, faça primeiro uma revisão cuidadosa da actividade e o conteúdo relacionado, bem como dos objectivos que pretende abordar. Reúna todos os materiais com antecedência!

- Tenha um plano alternativo para responder de maneira flexível a circunstâncias imprevistas (exemplo, em termos de calendário, clima ou reacções dos alunos).

- Consulte a secção sobre Recursos Adicionais no fim deste livro, que contém uma bibliografia sobre métodos de ensino e aulas experimentais.

- Se for possível, escolha actividades que tornem a aprendizagem divertida!

\section{NOTAS ESPECIAIS PARA}

O ENSINO DE DIREITOS, GÉNERO, SEXUALIDADE, HIV E SAÚDE SEXUAL:

Se você estiver num contexto de educação mista, tente separar rapazes das raparigas para a realização de algumas actividades ou discussões de modo a permitir uma sensação de compreensão mútua e abertura antes de voltar a reunir os grupos para mais discussões. Se for necessário, utilize áreas separadas da mesma sala. 


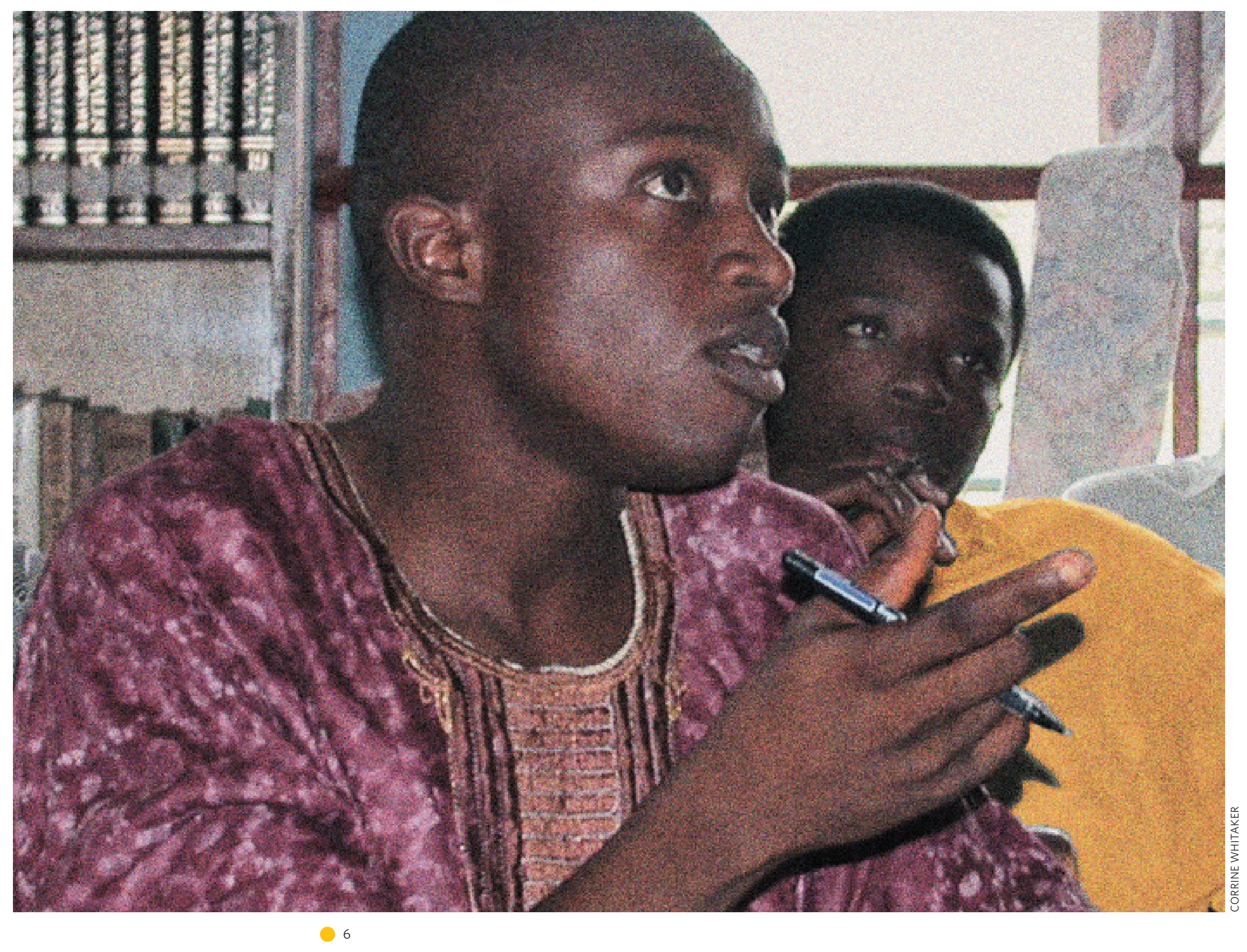




\section{NOTAS ESPECIAIS PARA \\ O ENSINO DE DIREITOS, \\ GÉNERO, SEXUALIDADE, HIV E SAÚDE SEXUAL:}

\section{Aproveite o poder dos alunos para reflectir, estudar, pensar de forma crítica sobre as suas} próprias vidas e sobre o mundo que os rodeia e para resolver problemas.

- Incentive os alunos a questionar a sabedoria convencional. Peça-lhes para pensarem nas suas convicções e nos padrões e normas da sua comunidade. Convide-os a explorar opiniões diferentes das suas de uma forma respeitosa.

- Inicie conversas com perguntas abertas. Use o método Socrático perguntando "porquê" como forma de ajudar os alunos a explorar contradições e a procurar verdades mais profundas. As Unidades 1 a 7 no livro de DIRECTRIZES incluem "Pontos de Reflexão" especiais. Estes apresentam perguntas que incentivam uma análise crítica e discussão.

- Incentive a criatividade.

- Encoraje os alunos a assumirem riscos no seu pensamento e a não terem medo de cometer erros. Esteja pronto para demonstrar esse comportamento.

- Organize pequenos grupos para explorarem questões e envolverem-se em actividades colectivas.

- Incentive várias perspectivas de análise de problemas e de possíveis soluções.

\section{Incentive a capacidade dos alunos de aplicar o que aprendem às suas vidas e} comunidades, ou seja, ajude-os a tornarem-se cidadãos activos e forças de uma mudança positiva.

- Seleccione o conteúdo que é relevante e métodos de ensino que convidem ao pensamento crítico. Peça aos alunos que relacionem o conteúdo às suas próprias vidas e ao mundo. Incentive-os a considerar o material à luz dos princípios de equidade e justiça social.

- Reúna oportunidades de aprendizagem que impliquem pesquisa e acção baseada em serviços ou na comunidade. Tenha em atenção a cultura em que trabalha para que possa evitar colocar os alunos em perigo.

- Considere se e como terá de defender na sua instituição (e na comunidade) a capacidade e o direito dos jovens de falar e agir sobre as suas próprias ideias.

- Lembre-se que os jovens muitas vezes inspiram-se nos seus professores e líderes comunitários.
Esteja ciente de que os alunos podem estar a repensar algumas premissas básicas que sempre tomaram como certas. Ajude-os a equilibrar os seus ideais e ambições enquanto aprendem como proteger a sua estabilidade e segurança nas suas casas e comunidades.

Poderá enfrentar resistência ao ensino destes tópicos básicos.

Saiba quem são os seus principais aliados dentro da sua organização e na comunidade. Também esteja ciente dos que poderão opor-se aos seus esforços. Procure apoio e orientação. 


\section{MÉTODOS DE ENSINO INTERACTIVOS PARA ENRIQUECER UM CURRICULO}

A utilização de uma diversidade de métodos permite-lhe abarcar uma maior variedade de alunos e ajuda a mantê-los envolvidos. Os alunos conseguem, assim, estabelecer ligações criativas entre as matérias. A seguir são apresentados os métodos mais comuns destinados a promover o interesse dos alunos, em conjunto com uma orientação básica sobre o seu uso.

Estimulantes - Estas são breves actividades de grupo destinadas a promover sentimentos positivos sobre o grupo. Elas concentram a energia do grupo e podem ser usadas para trazer novas ideias. Estas actividades apoiam o pensamento criativo. São particularmente úteis no início de uma sessão, ou para mudar o rumo da conversa. Alguns exemplos: sessões de familiarização, jogos de nomes, canções e exercícios físicos.

Estimuladores de discussão - Estas actividades levantam questões e moldam as perguntas para que os alunos possam explorar ainda mais. Normalmente são mais eficazes no início de uma aula. Alguns exemplos: chuva de ideias, estudos de caso, perguntas ou afirmações usadas para induzir respostas escritas, exercícios do tipo concordo/discordo, colocação de problemas, bem como curtas-metragens e leituras.

Jogos criativos - As actividades criativas mantêm os estudantes motivados. Elas estimulam novos processos de pensamento e ideias. Além disso, permitem aos estudantes, que aprendem e comunicam melhor nestes modos, participar de uma forma significativa. Alguns exemplos: projectos de arte, dramatização e teatro, poesia e escrita criativa. 
Discussões de grupo - Os alunos devem ter a oportunidade de se expressar, de ser ouvidos e de ouvir os outros. Isto ajuda-os a desenvolver as suas habilidades verbais e de escuta. Também podem aperfeiçoar as suas habilidades de pensamento e alargar as suas ideias e aumentar o conhecimento. Além disso, estas actividades podem ser usadas para dar a todos a oportunidade de participar e incentivar valores e cultura democráticos. Alguns exemplos: diálogos informais, discussões em painel e debates.

Refilexão e análise participativas - Divida a sua turma para que trabalhe em grupos com vista a resolver problemas e a incentivar a unidade de grupo e o pensamento crítico. Alguns exemplos: mapeamento comunitário, "árvores de problemas," projectos de investigação e análise de mensagens dos órgãos de informação.

Refilexão pessoal - Estas actividades ajudam os alunos a obter uma visão das suas próprias experiências. Elas incentivam a maturidade e a capacidade de discernimento. Podem abrir as portas para novas atitudes e comportamentos. Alguns exemplos: manter um diário, memórias guiadas, clarificação de valores e projectos de arte criativos.

Outras ferramentas participativas para a sala de aula - Outras actividades envolventes são a definição de objectivos de grupo e individuais; a atribuição de papéis de participação com vista a ajudar a gerir a sala de aula (repórter do dia, leitor de citações, controlador do tempo, chefe do dia); a revisão da aula e do que foi aprendido. 


\section{considerações especiais no desenvolvimento e implementação de um programa}

Um Só Programa é adequado para uma audiência global. Tem como base princípios universais; daí que se possa recorrer a ele para desenvolver um programa eficaz ou uma unidade de estudo para a sua população ou contexto local. Para tal, é necessário que preste atenção a uma gama de factores educacionais e programáticos que incluem as habilidades dos alunos, as competências dos professores, a preparação dos pais, os valores comunitários e a quantidade de tempo na sala de aula que tem disponível para um determinado tópico. As questões apresentadas a seguir pretendem orientálo ao considerar estes tópicos no desenvolvimento de um programa. Algumas destas questões podem ser da responsabilidade de outras pessoas - por exemplo, o pessoal da organização encarregue da implementação ou defensores comunitários. No entanto, estas questões são aqui incluídas porque a sua abordagem pode ser a chave para desenvolver um currículo de sucesso em sexualidade ou prevenção da transmissão do HIV. (Para referências e links de materiais que oferecem uma orientação mais detalhada sobre estas matérias, ver a secção Recursos Adicionais.)

\section{Considerações de políticas}

Quais são as políticas e recursos nacionais e locais que podem afectar o seu grau de sucesso no desenvolvimento de um currículo? Por exemplo, quais são as leis ou políticas que regem a educação sobre a sexualidade e/ou a prevenção do HIV nas escolas? Que iniciativas existem destinadas a garantir que a educação sexual abranja jovens portadores de deficiência? Os gestores de programas estão cientes da pesquisa que mostra as ligações existentes entre a gravidez na adolescência, as taxas de ITS, a igualdade de género e os direitos humanos? O programa foi desenhado de modo a ter em conta estas ligações? Existem fontes de financiamento diversificadas a que o seu programa ou escola possa recorrer? Deve dirigir os seus esforços de advocacia aos principais órgãos decisores na comunidade, pessoal da sua organização, ou outras pessoas? Quem são os seus principais aliados? 


\section{Considerações de planificação}

O currículo integra-se nos objectivos educacionais mais gerais da comunidade? Quais são as principais questões de planificação? Será que elas irão afectar o grau de sucesso da implementação do programa? Que trabalho de base prévio foi (ou deve ser) realizado? Por exemplo, qual a melhor forma de garantir que os principais membros do quadro do pessoal e parceiros estejam claros quanto à ênfase do programa e empenhados em vê-lo bemsucedido? De que maneira os organizadores de programas podem incentivar o apoio dos pais e membros da comunidade? Que tipos de recursos estão disponíveis que permitam aos pais comunicar eficazmente com os seus filhos sobre as questões de saúde sexual? Como é que os organizadores de programas podem aprender da experiência e de esforços semelhantes? Como podem identificar e treinar professores e outro pessoal? Quais são as melhores formas para estabelecerem contactos com os serviços de saúde, de aconselhamento e outros de referência existentes? Quem poderia estar interessado em juntar-se a um comité de gestão ou grupo de trabalho para dar o seu contributo ao desenvolvimento do programa? Por exemplo, os membros da comunidade, os jovens, pais, representantes dos professores e líderes das escolas e de ONG podem contribuir com ideias importantes. Este processo ajudá-lo-á a identificar e a obter os recursos disponíveis. Tornará o programa mais forte e mais adequado ao contexto local e dará aos principais membros da comunidade um sentido de apropriação do programa. Que oportunidades existem para comunicar e educar os membros da comunidade acerca do programa? Qual a melhor forma de reunir várias ideias na fase inicial do desenvolvimento de programas? A título de exemplo, poderá pensar em reuniões individuais com líderes comunitários, grupos focais ou inquéritos aos pais e professores. Qual a melhor maneira de se preparar para atender às preocupações que a comunidade poderá ter em relação ao currículo?

\section{Desenvolvimento de um currículo para ser usado com sérias limitações de recursos}

Que recursos tem à sua disposição num determinado contexto? De que forma o conteúdo do currículo pode ser adaptado de modo a abordar a maneira como a pobreza interage com o género, os direitos, a sexualidade e a saúde sexual? Como pode adaptar o programa em locais com poucos recursos? Por exemplo, pode contar com estratégias de ensino verbal ou com espaço ao ar livre para as aulas? As organizações não-governamentais ou os membros da comunidade podem dar ajuda em espécie?

\section{FACTO}

É importante prestar atenção a questões de políticas e educacionais para a criação de programas de educação em matéria de sexualidade e HIV. 


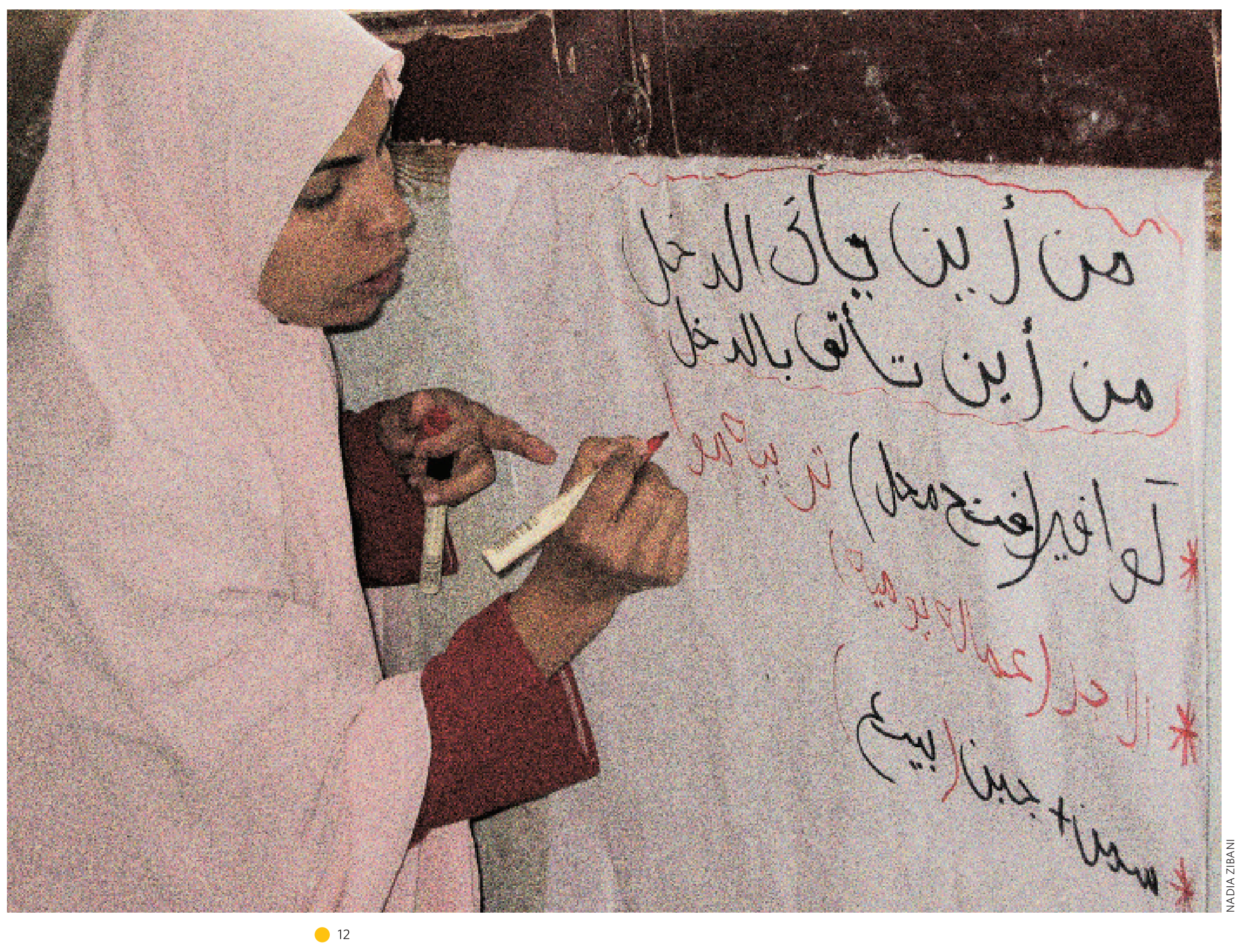




\section{Como ligar o seu currículo aos padrões de aprendizagem académica}

Cada uma das actividades contidas no presente livro inclui um objectivo relacionado com aptidões académicas gerais (por exemplo, escrita expositiva, escrita narrativa, resolução e análise de problemas, planificação e implementação de um projecto de investigação simples ou como falar em público). Isto facilita a inclusão da educação sexual e sobre o HIV nas aulas que não sejam de saúde e biologia, e especifica como estas actividades podem ajudar os professores e as escolas a realizarem os objectivos da educação. Ao desenhar um programa para o contexto escolar, tome em consideração as seguintes questões: Que padrões de aprendizagem ou marcadores de avaliação já existentes devem ser atingidos para uma determinada área temática? Que unidades ou conteúdo no livro de DIRECTRIZES estão melhor ligados a esses padrões? Olhando para os objectivos académicos das seguintes actividades, quais são os que melhor apoiam o progresso rumo ao cumprimento desses padrões? Que oportunidades de colaboração existem entre as áreas temáticas para uma abordagem interdisciplinar de prevenção do HIV ou de promoção da igualdade de género? Ao invés de competir com o programa geral, como é que uma abordagem criativa em relação à educação sexual /do HIV pode melhorar a qualidade do ensino em geral?

\section{Adaptação relevante para populações específicas}

De que forma os professores podem garantir que o conteúdo e as actividades sejam relevantes às necessidades de populações específicas? Por exemplo, como pode modificar as actividades sugeridas para grupos de baixo nível de alfabetização? Pode garantir que o conteúdo reflicta as preocupações de grupos como trabalhadores migrantes jovens, raparigas adolescentes casadas, soldados ou órfãos? Como pode atender aos desafios de aprendizagem enfrentados por tais populações? Pode disponibilizar um espaço seguro? Pode adaptar as aulas de modo a que se enquadrem num calendário mais curto? Como pode abarcar os alunos com poucas ligações com as instituições comunitárias? De que recursos da comunidade e referências irão mais provavelmente necessitar? 


\section{Preparação dos professores}

Os professores estão preparados para assumir uma abordagem interactiva e centrada no aluno? Terão a oportunidade de desenvolver tais habilidades? Qual é a melhor forma de equiparar o currículo a estas habilidades? Que tipo de formação permitirá aos professores examinar as suas próprias convicções pessoais e religiosas acerca da sexualidade e género para que estejam melhor preparados para ensinar estes tópicos de uma maneira que corresponda aos princípios internacionais dos direitos humanos? O que permitirá aos professores trabalhar de uma forma mais eficaz em contextos altamente conservadores?

\section{Pensar na avaliação}

Muitos educadores pretenderão avaliar os efeitos dos seus programas sobre a sexualidade e o HIV. Que resultados ou marcadores melhor mostrariam o progresso rumo à realização dos objectivos do programa? Por exemplo, os conhecimentos, atitudes e comportamentos específicos dos alunos mudarão? O programa reduzirá a coacção e a violência no relacionamento íntimo? Será que vai manter os alunos na escola ou num programa de aprendizagem? Irá aumentar a participação cívica? Os novos programas de educação terão uma fase piloto que possa permitir aulas e ajustamento prévios?

\section{Procure ajuda e mantenha-se estimulado}

Você irá trabalhar com o objectivo de criar e desenvolver um novo currículo sobre a sexualidade, género e direitos humanos. Em muitos contextos, este trabalho pode confrontar-se com atitudes de cepticismo e oposição. Para ajudar a ultrapassar tais respostas, construa pontes com antecedência com os membros e instituições da comunidade. Procure envolver os principais membros da comunidade - incluindo os pais - de uma forma significativa antes de iniciar o trabalho. Mantenha um contacto aberto e honesto com estas pessoas. É crucial manter o seu próprio moral e o dos parceiros do programa. Dedique um tempo para reflectir sobre o programa. Como é que está a avançar? Está a atingir os seus objectivos? São necessárias correcções do rumo?

Celebre as suas realizações e não desista nos seus esforços! 


\section{NOTAS FINAIS}

1 Note-se que este material contém uma breve introdução ao ensino interactivo e centrado no aluno; não inclui, nem substitui um workshop de formação ou manual nesta área. A secção relativa aos Recursos Adicionais, no fim deste volume, apresenta uma bibliografia de leituras e materiais seleccionados nesta área.

2 Em todo o mundo, o ensino interactivo e centrado no aluno tem um fundamento importante na teoria de Paulo Freire de "pedagogia crítica." Para factos relacionados com os resultados, nomeadamente realização académica, atitudes dos estudantes, retenção dos alunos e auto-estima, ver: Gross Davis, Barbara. 1993. Tools for Teaching. San Francisco: JosseyBass Publishers; Manswell Butty, Jo-anne. 2001. "Teacher instruction, student attitudes, and mathematics performance among 10th and 12th grade Black and Hispanic students," Journal of Negro Education 70(1/2): 19-37; Prince, Michael. 2004. "Does active learning work? A review of the research," Journal of Engineering Education 93(3): 223-231; Slavin, Robert. 1980. "Cooperative learning," Review of Educational Research 50(2):

315-342.

3 Em alguns contextos, os educadores também se referem a habilidades de pensamento crítico como metacognição. Para uma discussão sobre as habilidades metacognitivas e como incentivar tais habilidades na sala de aula, ver Martinez, Michael. 2006. "What is metacognition?" Phi Delta Kappan 87(9):696-699.

4 Kirby, Doug. 2007. “Emerging Answers 2007: Research Findings on Programs to Reduce Teen Pregnancy and Sexually Transmitted Diseases." Washington, DC: Campanha Nacional de Prevenção da Gravidez na Adolescência e Não Planificada.

Pettersson, T. 2003. "Basic Values and Civic Education: A Comparative Analysis of Adolescent Orientations towards Gender Equality and Good Citizenship." World Values Survey. <www.worldvaluessurvey.org/

library/>. Consultado a 13 de Maio de 2009.
6É importante que haja um simples contacto de abertura, em que os participantes produzem as regras e as directivas para a aula e para as discussões. Alguns professores chamam a isto "uma declaração de direitos da turma" ou dão-lhe outros títulos semelhantes. Ver, por exemplo, actividades sobre como "Criar regras orientadoras" (Making guiding rules) no Capítulo 1 de qualquer das três séries de HIV/AIDS Alliance's Our Future (programa de educação sobre a sexualidade e habilidades para a vida na Zâmbia): < https://www.aidsalliance.org/ resources/351-our-future-sexuality-and-lifeskills-education-for-youngpeople. Consultado a 27 de Abril de 2018. >. Consultado a 13 de Maio de 2009

7 Ver, por exemplo, o Capítulo 1 de qualquer das três séries de HIV/AIDS Alliance's Our Future (programa de educação sobre a sexualidade habilidades para a vida na Zâmbia): <https://www.aidsalliance.org/ resources/351-our-future-sexuality-and-lifeskills-education-for-youngpeople>. Estas incluem actividades sobre "Confiança e guardar segredos" "Trabalhar juntos com respeito."

${ }^{8}$ Conforme indicado nas Dicas de Ensino referentes à Unidade 3 no volume DIRECTRIZES, deve prestar atenção ao facto de que poderá estar legalmente vinculado a requisitos obrigatórios de notificação, por exemplo, se um aluno revelar casos de abuso sexual. Conheça quais são esses requisitos no local onde se encontra.

9 Estudiosos documentaram a grande variação registada nas forças, estilos e necessidades de aprendizagem das pessoas. Por exemplo, a ideia de múltiplas inteligências desafiou o conceito de uma única forma de inteligência (Gardner, Howard. 2006. Multiple Intelligences: New Horizons. 2a edição revista. New York: Basic Books. < https:// www.amazon.com/Multiple-Intelligences-Horizons-Theory-Practice/ $\mathrm{dp} / 0465047688>$ ). 


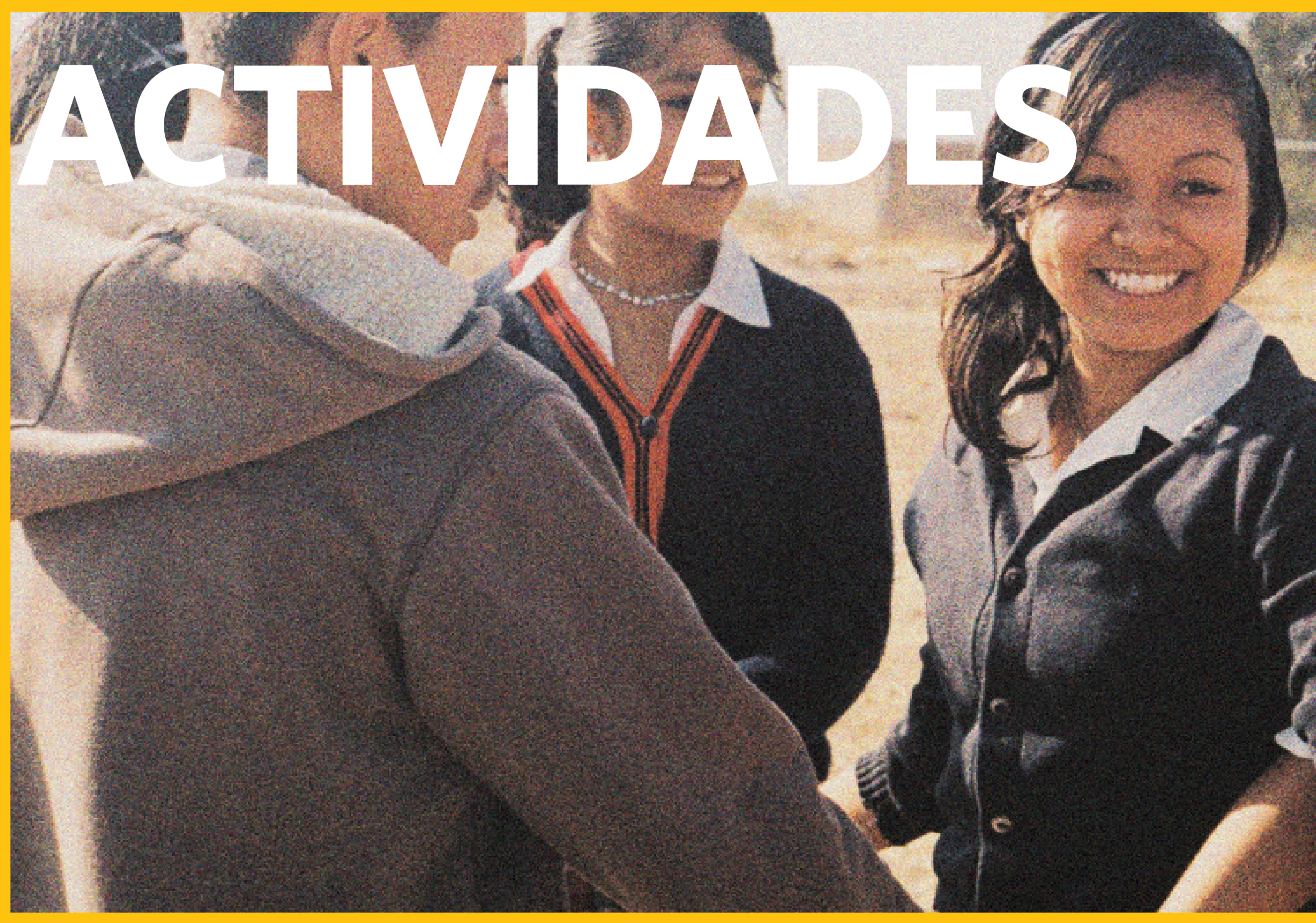




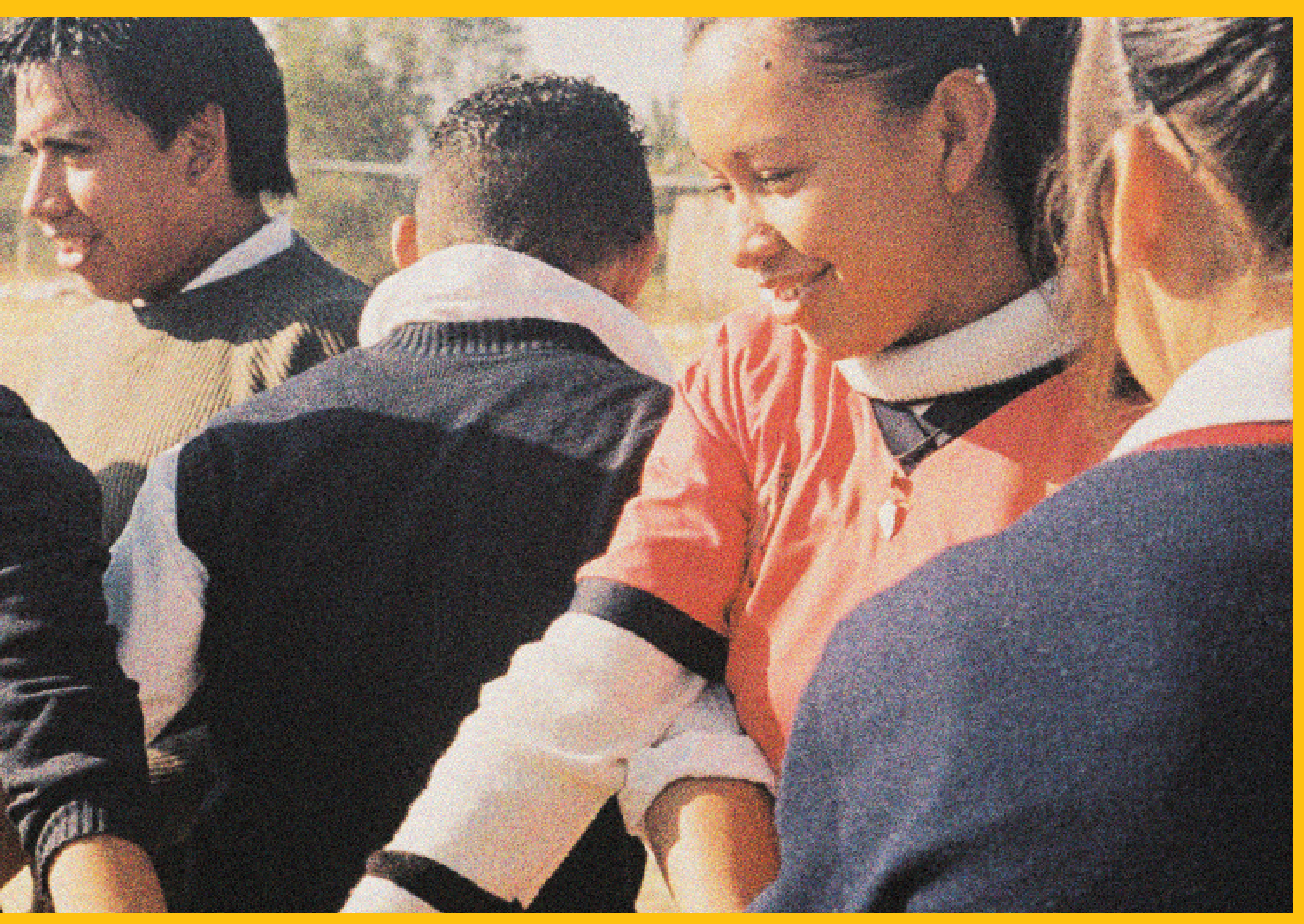


PARA ALUNOS MENORES DE 15 ANOS

Embora este livro tenha sido desenvolvido essencialmente tendo em mente adolescentes mais velhos, muitas das actividades são apropriadas ou adaptáveis a crianças até de dez anos, dependendo do seu contexto.

Para estes alunos mais novos, as 21 actividades que podem ser mais úteis para si são:

unidade 1 actividade $\mathbf{1}$

unidade 2 actividades 5-6, 8-11, 15

unidade 3 actividades 18, 20

unidade 4 actividades 27, 29, 32

unidade 5 actividade 36

unidade 6 actividades 40-43

unidade 7 actividades $\mathbf{4 9 - 5 0}$

unidade 8 actividade 53

\section{bem-vindos às actividades de aprendizagem no Um Só Currículo!}

\author{
Estas actividades foram desenvolvidas para serem práticas e eficazes.
}

Cada actividade foi concebida tendo em mente a aprendizagem em geral; afinal, a educação sexual e HIV podem e devem reforçar o sucesso académico geral.

Para apoiar este objectivo, estas actividades são criadas em torno de dois tipos de objectivos de aprendizagem: (1) aprendizagem relacionada com o tema em discussão e (2) fortalecimento de competências académicas específicas, tais como o pensamento de ordem superior ou crítico, a escrita, a investigação, falar em público e a planificação em colaboração e a resolução de problemas. Além disso, porque estas actividades são significativas e muitas vezes divertidas, elas podem incentivar o envolvimento de estudantes e a ligação com a escola.

\section{Cada actividade está ligada a um conteúdo específico no livro de DIRECTRIZES.}

Com efeito, algumas das actividades implicam a utilização de fichas técnicas do livro de DIRECTRIZES, a que se pode ter acesso em $<$ www.itsallone.org $>$.

Embora todo este conjunto de actividades seja apropriado para jovens de quinze anos ou mais, muitas das actividades individuais podem ser usadas com crianças mais novas.

Ver a lista na margem esquerda referente às actividades que são também adequadas a jovens dos 10 anos 14 anos.

As actividades são acompanhadas de fichas para distribuir aos participantes (Fichas do Aluno, Fichas Técnicas, Chaves de Respostas para os Professores e Informação para os Professores).

Com estas ferramentas úteis, as actividades estão prontas para serem usadas. Para ajudá-lo a garantir que satisfaça as necessidades precisas dos seus alunos, favor rever as notas da página a seguir. 
PARA AS ESCOLAS: Como forma de maximizar o seu aspecto prático para uso na escola, a maior parte das actividades foi concebida para ser concluída numa única sessão (ou ocasionalmente em duas ou três sessões) de 40 minutos. Conforme referido na página anterior, estas actividades incluem objectivos académicos. Porque se trata de actividades significativas e agradáveis do ponto de vista pessoal, elas também podem promover a ligação dos alunos com a escola.

\section{PARA PROGRAMAS BASEADOS NA COMUNIDADE:}

As seguintes actividades referem-se a "alunos", e não a "participantes." Escolhemos esta terminologia por uma questão de simplicidade, mas o termo não se refere apenas aos que aprendem na sala de aula. Todos nós somos estudantes, quer estejamos na escola, quer não!

\section{PARA OS NOSSOS ALUNOS COM UM ÍNDICE BAIXO}

DE ALFABETIZAC̣ÃO: Embora muitas das actividades envolvam a escrita, a maioria pode ser adaptada rapidamente como actividades orais para serem usadas em contextos em que os alunos tenham habilidades de alfabetização limitadas ou não tenham nenhumas. Por exemplo, muitas destas actividades podem ser adaptadas criando cartões com imagens que retratem os tópicos de discussão.

\section{PARA FACILITAR A SUA PLANIFICAC̣̃̃: Cada}

actividade inclui uma breve visão geral, os objectivos da aprendizagem, o tempo necessário para a realização da actividade (duração), uma lista de materiais de que necessitará e quaisquer passos necessários para a preparação. Também estão incluídas instruções detalhadas para ler para os alunos; estas podem ser adaptadas da maneira que considerar apropriada e com que se sinta à vontade.
Leia a actividade duas vezes antes de apresentá-la para ajudá-lo a prever como quererá apresentar a aula. Poderá fazer um teste com alguns colegas ou amigos para se familiarizar com o processo e abordagem da actividade. Claro que como parte da planificação de qualquer aula, terá que se familiarizar com o respectivo conteúdo no livro de DIRECTRIZES (ou no seu próprio currículo).

PARA DIFERENTES CONTEXTOS CULTURAIS: As actividades podem ser usadas numa grande variedade de contextos. Todavia, poderá achar que algumas actividades são mais apropriadas do que outras para o seu contexto. As instruções referentes a várias actividades também sugerem que pode alterar os nomes ou situações contidos nos exemplos para que sejam mais reconhecíveis e confortáveis para os seus alunos.

UMA NOTA SOBRE A SELECC̣̃̃O DE ACTIVIDADES:

Estas actividades não constituem um currículo fixo. Pelo contrário, são uma amostra de actividades para usar ou adaptar ao moldar o seu próprio programa ou planos de aula. Seleccione as actividades que melhor complementem qualquer palestra, material escrito, filme, ou outras componentes que fazem parte do que ensina. A bibliografia de recursos adicionais no fim deste volume inclui links para mais currículos.

UMA NOTA SOBRE O MATERIAL: Muitas das actividades indicam que necessitará de um quadro e giz. Claro que poderá usar papel de jornal e marcadores, quadro branco ou qualquer superfície que seja suficientemente larga para os alunos conseguirem ler.

UMA NOTA SOBRE A PROGRAMAÇÃO: A duração destas actividades é flexível, dependendo da dimensão e das características do seu grupo e do tempo que dedica à discussão. É importante deixar tempo de discussão para o fim, caso seja indicado nas instruções. 


\section{porque a justiça é importante}

\section{DURAC̣ÃO:}

Etapas 1-2: 15 minutos (pode ser dado previamente, por exemplo, como trabalho de casa no dia anterior)

Etapas 3-7: 40 minutos

\section{MATERIAL:}

Quadro + giz

\section{PREPARAC̄̃̃O:}

Fazer a revisão das citações. Se tiver acesso a uma fotocopiadora, tirar cópias de todas as citações para cada aluno. Se não tiver, escrever todas as citações no quadro antes do iníció da aula. Decidir se pretende dar as Etapas 1-2 como trabalho de casa antes de passar para a Etapa 3.
VISÃO GERAL: Os alunos pensam na questão de equidade respondendo às citações de pessoas proeminentes.

OBJECTIVOS: Ajudar os alunos a entender a importância da equidade e a ligação entre esta e os direitos humanos; fortalecer as habilidades analíticas e de escrita.

\section{INSTRUC̣ÕES}

1 Explicar que estas citações são de pessoas proeminentes de todo o mundo. Peça aos alunos que leiam as citações em voz alta, uma de cada vez. Não discutam as citações neste momento.

A equidade é o que a justiça realmente é.

As mulheres não estão a morrer por causa de doenças que não conseguimos tratar, elas estão a morrer porque as sociedades ainda têm que tomar a decisão de que vale a pena salvar as suas vidas.

O futuro será moldado pela nossa justiça em relação aos filhos das outras pessoas.

Sejam simpáticos porque todas as pessoas que encontram na vida estão a travar uma grande batalha.

Sejam justos com os outros, mas depois fiquem atentos até que eles sejam justos convosco.

A justiça coloca o brilho nas estrelas

Vivam de modo a que quando as outras pessoas pensarem em justiça e respeito pensem em vós.

Nos nossos corações e nas nossas leis devemos tratar todas as pessoas com justiça e dignidade, independentemente da sua raça, género, idade, convicções políticas ou religião.
2 Leia as seguintes instruções para os seus alunos:

- Escolham uma citação que vos inspire.

- Escrevam pelo menos uma página do que pensam que significa e porque "vos diz alguma coisa" ou vos inspira.

- Incluam um exemplo da vossa própria vida ou de algo que tenha acontecido na vossa comunidade ou noutro local em que esta mensagem teria sido útil. Pode ser um exemplo de um momento em que tenham sido maltratados, ou em que não tenham tratado uma outra pessoa com justiça, ou tenham testemunhado uma interacção entre outras pessoas.

- Como é que a mensagem desta situação poderia ter sido útil?

- Mais tarde, terão a oportunidade de ler o vosso trabalho ao resto do grupo, mas não são obrigados a fazê-lo.

- Alguém tem alguma pergunta sobre o trabalho? 
3 Peça a voluntários que partilhem a sua resposta escrita à citação escolhida. (Se já tiver recolhido e lido qualquer destas respostas, poderá seleccionar um ou dois alunos para iniciar o processo de partilha). Em seguida, agradeça a cada aluno por ter partilhado a sua resposta.

4 Se os primeiros dois ou três alunos tiverem escrito sobre uma situação em que eles tenham sido tratados injustamente, pergunte se alguém tem um exemplo em que uma outra pessoa tenha sido tratada injustamente, ou um exemplo de alguém que tenha tratado injustamente uma outra pessoa.

5 Agradeça aos leitores voluntários e em seguida pergunte ao grupo:

- É sempre fácil ser justo?

- Olhem para a última citação ("Nos nossos corações...")

- Nos nossos corações nós tratamos todas as pessoas com justiça e dignidade, independentemente destes tipos de diferenças? Alguém pode dar um exemplo? [Se possivel, incentivar os alunos para que pensem em exemplos da sua própria sociedade e também exemplos do que tenham ouvido sobre acontecimentos num outro pais.]
6 Diga aos alunos:

- As pessoas nem sempre concordam em relação ao significado de se comportar com justiça e dignidade uns para com os outros, ou em relação à maneira como as pessoas têm o direito de ser tratadas.

Contudo, durante mais de 50 anos, a comunidade global concordou que todas as pessoas merecem ser tratadas com respeito e dignidade.

- Por uma questão de equidade, todas as pessoas merecem certas protecções e direitos básicos. Estes direitos são chamados "direitos humanos". Referem-se à forma como tratamos as outras pessoas e como membros de uma sociedade apenas porque somos seres humanos.

7 Pergunte e dê espaço para discussão:

- Podem pensar num direito básico que todas as pessoas deveriam ter? [Sondar direitos como: alimentação, habitação, educação e segurança.]

- Será que todos, de facto, gozam destes direitos básicos?

- Voltem para a citação original sobre a qual escreveram. Essa situação de equidade/justiça aplica-se à ideia geral de direitos humanos?

\section{INFORMACÃO AOS} PROFESSORES

As citações desta actividade são atribuídas às seguintes individualidades (seguindo a ordem em que aparecem na Etapa 1): Justice Potter Stewart; líder médico egípcio Mahmoud Fathalla; defensora dos direitos Marian Wright Edelman; antigo filósofo grego Philo; actor

Alan Alda; anónimo; escritor $\mathrm{H}$. Jackson Brown, Jr.; antigo Presidente dos Estados Unidos Bill Clinton. 


\section{introdução aos direitos humanos}

\section{DURAC̣ÃO:}

Etapas 1-2: 40 minutos

\section{Etapas 3-5: 45 minutos}

\section{MATERIAL:}

Quadro + giz; pelo menos uma cópia da folha com a Informação para os Professores: "Declaração Universal dos Direitos Humanos."

\section{PREPARAC̣ÃO:}

Esta actividade deve ser realizada depois de os alunos terem explorado os valores reflectidos nos direitos humanos, tais como a igualdade e a não discriminação. Rever a Declaração Universal dos Direitos Humanos e certificar-se de que entende o significado de cada direito.
VISÃO GERAL: Os alunos elaboram uma lista de direitos que gostariam de ter para um novo país imaginário e comparam a sua lista com a Declaração Universal dos Direitos Humanos. Também entrevistam adultos sobre como entendem o termo "direitos humanos."

OBJECTIVOS: Habilitar que os alunos descrevam o conceito de direitos humanos e consigam indicar vários direitos humanos básicos; fortalecer as habilidades de pensamento abstracto.

\section{INSTRUC̣ÕES}

1 Divida os alunos em grupos de quatro ou cinco pessoas. Diga aos alunos:

- Vocês vão fixar-se numa ilha nova que tem tudo o que é necessário para sustentar a vida humana. Ninguém já alguma vez lá viveu, pelo que não existem leis, nem história.

- Devem elaborar uma lista de dez direitos humanos que se aplicarão automaticamente a todas as pessoas nesta ilha.

- Nenhum de vós sabe qual será a sua posição, género, etnicidade/raça, classe ou orientação sexual. Têm dez minutos para elaborar a vossa lista.

2 Peça a cada grupo que apresente a sua lista. Compile uma "lista do grupo" unificada que inclua todos os direitos mencionados.

3 Apresente a Declaração Universal dos Direitos Humanos (DUDH). Explique que se trata de uma lista de direitos para todas as pessoas do mundo. Peça a cada pessoa que leia um "Artigo" em voz alta. Depois de ler os artigos, pergunte se alguém tem alguma pergunta a fazer sobre qualquer deles.
4 Peça aos alunos que regressem aos pequenos grupos por 10 minutos para analisar os seguintes aspectos:

- Quais são algumas semelhanças existentes na nossa lista e na lista da Declaração Universal?

- Que direitos da DUDH não incluímos?

- Queremos acrescentar mais alguns direitos à nossa lista?

- Alguns direitos contidos na lista dos grupos não estão incluídos na Declaração Universal?

5 Volte a reunir os grupos e analise as suas respostas às perguntas da Etapa 4. Pergunte qual a importância de ter uma lista de direitos humanos aprovada universalmente que se aplica a todas as pessoas.

Trabalho de Casa: Entrevistar dois adultos, perguntando-lhes "O que significa para si o termo 'direitos humanos'? Pode dar-me um exemplo de uma questão relacionada com os direitos humanos que tenha ouvido falar?" Escrever sobre que assunto a pessoa lhe falou, o que você ficou a saber e algo que ache que poderia ser feito para abordar o assunto. 


\section{declaração universal dos direitos humanos numa linguagem simples}

A lista a seguir explica cada direito humano numa linguagem simples.

Para o texto oficial em português, ver <http://www.ohchr.org/EN/UDHR/Pages/Language.aspx?LangID=por $>$.

ARTIGO 1: Desde o nacimento, todas as pessoas são livres. Cada pessoa deve ser tratada da mesma maneira. Cada pessoa tem razão e consciência. Todos devemos agir com as outras de maneira amigável.

ARTIGO 2: Toda a pessoa pode reivindicar os seguintes direitos, independentemente do seu:

- género;

- cor da pele;

- língua;

- convicções políticas;

- religião;

- riqueza ou pobreza;

- grupo social;

- país de nascimento;

- estatuto de independente ou não do país.

ARTIGO 3: Toda a pessoa tem direito à vida, à liberdade e à segurança pessoal.

ARTIGO4: Ninguém será mantido em escravatura ou em servidão.

ARTIGO 5: Ninguém tem o direito de o torturar.

ARTIGO 6: Toda a pessoa tem direito de ser protegida pela lei, em qualquer sítio ou situação.

ARTIGO 7: A lei é igual para todos; deve ser aplicada da mesma maneira para todos.

ARTIGO 8: Toda a pessoa deve poder pedir assistência jurídica quando os direitos que o seu país lhe confere não são respeitados.

ARTIGO 9: Ninguém tem o direito de o colocar na prisão, de o manter preso ou de o deportar do seu país injustamente ou sem uma boa razão.

ARTIGO 10: Se tiver que ir a julgamento, esse julgamento deve ser realizado em público. As pessoas que o julgam não devem deixar-se influenciar por outros. 


\section{declaração universal dos direitos humanos numa linguagem simples}

ARTIGO 11: Toda a pessoa deve ser considerada inocente até se provar que é culpada. Se for acusada de um crime, tem o direito de se defender. Ninguém tem o direito de o condenar ou de o punir por algo que não fez.

ARTIGO 12: Tem o direito de pedir protecção se alguém tentar prejudicar o seu bom nome, invadir a sua casa, violar o seu correio, ou importuná-lo a si ou à sua família sem um bom motivo.

ARTIGO 13: Toda a pessoa tem o direito de circular livremente dentro do seu país. Tem o direito de abandonar o seu país para ir para outro; e tem o direito de regressar ao seu país, se assim o desejar.

ARTIGO 14: Se alguém o perseguir, tem o direito de procurar asilo (refúgio seguro) noutros países. Poderá perder este direito se tiver cometido uma grave violação dos direitos humanos.

ARTIGO 15: Toda a pessoa tem direito a uma nacionalidade e ninguém o pode impedir, sem um bom motivo, de pertencer a um outro país, se assim o desejar.

ARTIGO 16: Assim que uma pessoa estiver legalmente autorizada a fazê-lo, tem o direito de se casar e ter uma família. Nem a cor da sua pele, nem o país de origem, nem a sua religião devem impedi-lo de o fazer. Homens e mulheres têm os mesmos direitos quando estão casados e também quando estão separados. Ninguém deve forçar uma pessoa a casar. O governo do seu país deve proteger a sua família e os seus membros.

ARTIGO 17: Toda a pessoa tem o direito de possuir coisas e ninguém tem o direito de tomá-las sem uma boa razão.

ARTIGO 18: Toda a pessoa tem o direito de professar a sua religião livremente, mudar e praticar por conta própria ou com outras pessoas.

ARTIGO 19: A pessoa tem o direito de pensar o que quiser e de dizer o que quiser e ninguém deve proibi-lo de o fazer. A pessoa tem o direito de partilhar as suas ideias com qualquer um — incluindo pessoas de qualquer outro país.

ARTIGO 20: Toda a pessoa tem o direito de organizar reuniões pacíficas ou de participar em reuniões de uma forma pacífica. Ninguém tem o direito de forçá-lo a pertencer a um grupo.

ARTIGO 21: Você tem o mesmo direito que qualquer outra pessoa de tomar parte nos assuntos políticos do seu país fazendo parte do governo, ou escolhendo políticos que tenham as mesmas ideias que as suas. Os governos devem ser eleitos regularmente e a votação deve ser secreta. A pessoa deve ser permitida a votar, e todos os votos devem ser contados de forma igual. 


\section{declaração universal dos direitos humanos numa linguagem simples}

ARTIGO 22: A sociedade em que você viva deve ajudá-la a desenvolver e a tirar o máximo partido de todas as vantagens (cultura, trabalho, bem-estar social) que lhe são oferecidas e a todas as pessoas do seu país.

ARTIGO 23: Toda a pessoa tem o direito de trabalhar, de ser livre para escolher o seu trabalho e de receber um salário que lhe permita viver e sustentar a sua família. Se um homem e uma mulher fizerem o mesmo trabalho, devem receber a mesma remuneração. Todas as pessoas que trabalham têm o direito de se unir para protegerem e defenderem os seus interesses.

ARTIGO 24: Os dias de trabalho não devem ser muito longos porque todos têm direito a repouso e devem poder gozar férias remuneradas periódicas.

ARTIGO 25: Você tem o direito de ter tudo o que precisa para que ela e a sua família não fiquem doentes; não passem fome; tenham roupa e casa; de receber ajuda se não estiver a trabalhar, se estiver doente, se for idosa, se o seu cônjuge tiver falecido, ou se deixar de ter fonte de subsistência por qualquer outra razão que não puder evitar. Tanto uma mãe que vai ter um bebé como o seu bebé devem obter ajuda especial. Toda a criança tem os mesmos direitos que qualquer outra criança, quer a sua mãe seja, ou não, casada.

ARTIGO 26: Você tem o direito de ir à escola; todos devem poder ir à escola. O ensino primário deve ser gratuito. Você deve ser capaz de aprender uma profissão ou habilidade ou continuar os seus estudos até onde quiser. Na escola, você deve poder desenvolver todos os seus talentos. Você deve ser ensinada a conviver com os outros, independentemente da sua raça, religião ou origem. Os seus pais têm o direito de escolher como e o que lhe é ensinado na escola.

ARTIGO 27: Toda a pessoa tem o direito de partilhar as artes e ciências da sua comunidade e qualquer bem que façam. As suas obras como artista, escritor, ou cientista devem ser protegidas e deve poder se beneficiar delas.

ARTIGO 28: Para garantir que os seus direitos sejam respeitados, deve ser estabelecida uma "ordem" que possa protegê-los. Esta “ordem” deve ser local e mundial.

ARTIGO 29: Toda a pessoa tem deveres para com a sua comunidade. A lei deve garantir os seus direitos humanos. Ela deve permitir que todos respeitem os outros e que sejam respeitados.

ARTIGO 30: Nenhuma sociedade e nenhum ser humano, em qualquer parte do mundo, deve agir de tal forma que destrua os direitos que estão aqui enumerados.

Esta actividade é adaptada de $A B C$ : Teaching Human Rights- Practical activities for primary and secondary schools (Alto Comissariado para os Direitos Humanos. 2004. Nova lorque e Genebra: Nações Unidas. pp. 43-44 e 102-109.) A presente lista (adaptada em parte de World Association for the School as an Instrument of Peace, da Universidade de Genebra) explica cada direito humano em linguagem simples. Para o texto oficial em português, consultar <http://www.ohchr. org/EN/UDHR/Pages/Language. aspx? Lang $\mid \mathrm{D}=$ por $>$. 


\section{poder, privilégio e igualdade}

\section{DURACÃO:}

45 minutos

\section{MATERIAL:}

Quadro + giz

\section{PREPARAC̄ÃO:}

Acrescentar qualquer grupo à lista que se encontra a seguir que possa ser relevante para a sua comunidade em particular. Concluir a etapa 1 antes do início da sessão.
VISÃO GERAL: Os alunos identificam e reflectem sobre a relação existente entre o poder social e a experiência de privilégio ou discriminação.

OBJECTIVOS: Permitir que os alunos discutam os mecanismos do poder na sociedade, identifiquem como deter o poder está relacionado com a experiência de privilégio, discriminação e opressão e relacionar estas questões às suas próprias vidas; fortalecer as habilidades analíticas e de resolução de problemas.

\section{INSTRUÇÕES}

1 Desenhe um gráfico ou mapa com duas colunas no quadro. A primeira coluna deve chamar-se "maior poder/privilégio" e a segunda coluna "menor poder/ privilégio." Explique que os alunos irão discutir conceitos de poder, privilégio e igualdade nas suas próprias vidas e na sociedade.

2 Da lista com o título "Grupos que tendem a ter poder desigual na sociedade," leia o primeiro exemplo (pessoas ricas e pessoas pobres).

3 Pergunte: Que grupo deve ir para a coluna "maior poder"? Na coluna "menor poder"? Lembre aos alunos que estas caracterizações não são uniformemente verdadeiras ou absolutas.

4 Registe a resposta dos alunos na coluna apropriada. Analise o resto da lista, lançando as suas respostas em cada coluna. (No caso dos grupos étnicos, raciais e religiosos, poderá mencionar o nome de grupos específicos na sua zona.)
Grupos que tendem a ter poder desigual na sociedade:

Pessoas ricas / Pessoas pobres

Homens / Mulheres

Heterossexual / Homossexual

Chefe / Trabalhador

Político / Membro da comunidade

Cidadão / Refugiado

Pessoas sem deficiência / Pessoas com deficiência

Grupos étnicos maioritários / Grupos étnicos minoritários

Grupos religiosos maioritários / Grupos religiosos minoritários

Pessoas consideradas atraentes / Pessoas consideradas não atraentes 


\section{Pergunte:}

- Olhem a lista de grupos que tendem a ser mais privilegiados na sociedade. Conseguem encontrar um grupo nesta lista com que se identifiquem pessoalmente? Acham que este grupo normalmente goza de mais poder na sociedade? Escrevam umas frases que descrevam uma experiência que tiveram ou ouviram que ilustre esta diferença de poder. [Dar 3-5 minutos para os alunos escreverem.]

- Olhem para a lista de grupos que muitas vezes gozam de menos privilégios. Vejam se também se identificam pessoalmente com qualquer destes grupos. Concordam que o grupo que escolheram costuma ter menos privilégios? Escrevam um parágrafo que descreva uma experiência que tiveram ou ouviram que ilustre esta diferença de poder. [Dar 3-5 minutos para os alunos escreverem.]

- Levantem a mão se acharem que se identificaram com pelo menos um grupo de cada lista. A maior parte de nós sabe o que é usufruir de mais privilégios E ter menos privilégios?

6 Peça a alguns voluntários para lerem os seus episódios relacionados com estar num grupo com menos poder/ privilégio. (Não pressione ninguém para ler).

7 Discussão (1-2 respostas por pergunta):

- O que notam em relação ao tratamento que as pessoas dos grupos menos privilegiados recebem? [Sondar o seguinte: as que não têm poder são muitas vezes discriminadas ou oprimidas.]

- A que emoções este pode levar entre pessoas com menos poder? [Escrever estas emoções no quadro. Devem ser palavras de emoção, não descrições do que aconteceu.]
- O que notam em relação aos sentimentos ou emoções enumerados?

8 Volte às duas listas e pergunte:

- Pensem no conceito de igualdade. Peguem, por exemplo, no primeiro par (pessoas ricas e pobres). Como iriam completar a frase: "A igualdade entre as pessoas ricas e pobres ." O que vos vem à mente? [Não existe uma só resposta correcta.]

- Quem pode completar a mesma frase sobre igualdade para outro par de grupos? Tentem usar diferentes palavras ou até desenvolver uma outra ideia. [Repetir em relação a vários pares dentro do tempo permitir disponível.]

- Quem se lembra do primeiro artigo da Declaração Universal dos Direitos Humanos? [Nota: É o direito à igualdade. Escrever o primeiro artigo no quadro: "Desde o nacimento, todas as pessoas são livres.Cada pessoa deve ser tratada da mesma maneira. Cada pessoa tem razão e consciência. Todos devemos agir com as outras de maneira amigável."].

9 Encerre com uma discussão da seguinte pergunta (ou simplesmente incentive os alunos a ponderar sobre a pergunta ao saírem da sala): O que deve acontecer para que todos usufruam da igualdade e do direito à dignidade?

Trabalho de Casa: Responder por escrito à seguinte pergunta: $\mathrm{O}$ que poderiam fazer na vossa vida diária para promover uma maior igualdade e para reconhecer a dignidade de cada pessoa?
Adaptado de Helping Teens Stop Violence: A Practical Guide for Counselors, Educators, and Parents Allan Creighton and Paul Kivel. 1990, 1992. Alameda, CA: Hunter House Inc.). Para encomendar, visitar < http:// paulkivel.com/books/helping-teensstop-violence-build-community-andstand-for-justice/ > 


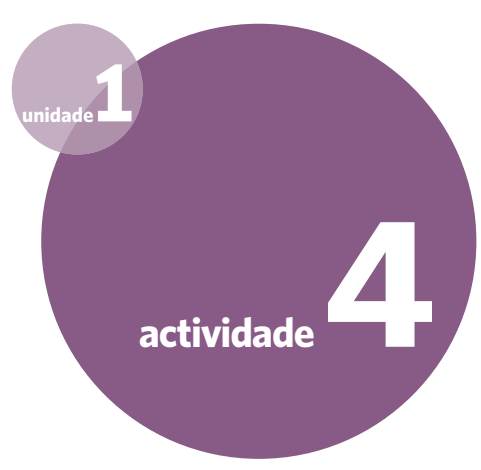

\section{DURAC̣ÃO:}

40-60 minutos, dependendo do número de casos analisados.

\section{MATERIAL:}

Quadro + giz; uma cópia de cada estudo de caso que vai ser usado. Poderá colocar a Parte 1 num lado da folha e a Parte 2 no outro lado, já que cada parte tem suas próprias questões para analisar.

\section{PREPARAC̣ÃO:}

Esta actividade deve ser realizada depois de ter sido apresentada aos alunos a ideia de direitos sexuais e reprodutivos. Seleccionar três estudos de caso da página seguinte ou recorrer a casos do seu país. Escrever perguntas da Etapa 2 no quadro com antecedência.

\section{estudos de caso relativos aos direitos sexuais e reprodutivos}

VISÃO GERAL: Os alunos analisam e discutem histórias verídicas que envolvam violações dos direitos sexuais ou reprodutivos.

OBJECTIVOS: Permitir que os alunos descrevam como o relacionamento íntimo e a sexualidade são afectados pela nossa capacidade de exercer os nossos direitos humanos; fortalecer as habilidades de pensamento crítico.

\section{INSTRUÇÕES}

1 Hoje vamos discutir histórias verídicas sobre os direitos sexuais e reprodutivos. Peça a um voluntário que leia em voz alta a $1^{\text {a }}$ Parte da história de Alicja. Ler apenas a $1^{\text {a }}$ Parte da história.

2 Depois da leitura da 1a Parte, peça aos alunos que escrevam respostas às seguintes perguntas nos seus cadernos. Ler as perguntas no quadro em voz alta:

- Como é que se sentem com este caso?

- Que direitos sexuais ou reprodutivos se relacionam com este caso?

- Acham que isto representa uma violação dos direitos humanos? Porquê?

- Quem é responsável? Enumerem todos que têm a mesma responsabilidade pelo que aconteceu.

3 Para cada pergunta, peça a um ou dois voluntários que leiam as suas respostas e em seguida peça que teçam alguns comentários.
4 Peça ao leitor inicial que leia a 2a Parte ("O que Aconteceu?"). Em seguida discutir:

- Como se sentem em relação ao resultado?

- Como é que o caso podia ter sido diferente se a vítima fosse rica (ou do sexo masculino ou heterossexual)?

- Que atitudes devem ser mudadas para proteger este direito sexual?

5 Repita estas etapas para cada estudo de caso na sua aula. (Dar dez minutos por caso.)

6 Depois de concluir todos os estudos de caso, terminar a aula perguntando:

- Conhecem casos semelhantes que tenham acontecido aqui? Que direitos foram violados?

- Ouviram falar de qualquer outro tipo de violações dos direitos sexuais no país ou noutros locais?

- O que deve ser feito para pôr fim a tais violações?

- A que conclusão se pode chegar sobre a relação existente entre os direitos humanos e a nossa vida íntima, romântica e sexual? [Pedir ideias e escrevêlas no quadro.] 


\section{estudo de caso sobre direitos sexuais e reprodutivos}

\section{ALICJA}

1a Parte: História de Alicja: Quando Alicja, uma polaca com problemas de visão desde a infância, engravidou, foi informada por muitos médicos que a sua gravidez e parto representavam um risco de danos irreversíveis à sua vista. Por lei, a Polónia permite que as mulheres façam o aborto quando a sua saúde está em perigo. Contudo, os médicos recusaram-se a passar uma certidão a Alicja autorizando a realização do aborto, pelo que ela não teve escolha e levou a gravidez a termo.

2a Parte: O que aconteceu com Alicja? O parto resultou numa maior deterioração da vista de Alicja. Ela deixou de poder trabalhar, ficou dependente de ajuda para realizar as actividades do dia-a-dia e para cuidar da criança, tornando-a totalmente dependente da assistência pública. O caso de Alicja foi levado ao Tribunal Europeu dos Direitos Humanos, que constatou que os governos têm o dever de estabelecer mecanismos eficazes com vista a garantir que as mulheres tenham acesso ao aborto onde é legal. O tribunal indemnizou-a por danos financeiros em reconhecimento da sua "angústia e sofrimento."

\begin{abstract}
AMINA
1a Parte: História de Amina: Amina era uma nigeriana divorciada e mãe de três filhos. Depois de namorar com Mohammed durante 11 meses, ele pediu-lhe para ter relações sexuais com ele, prometendo-lhe casamento. Ela concordou e engravidou. Contudo, Mohammed não se casou com ela e ela deu à luz uma menina fora do casamento. Foi acusada de adultério ao abrigo da lei religiosa. Mohammed jurou que não era o pai e foi deixado em liberdade, mas Amina foi acusada de adultério e condenada à morte por apedrejamento. Ela recorreu, mas o veredicto foi mantido. A sua execução foi diferida por dois anos para que pudesse amamentar o seu bebé.
\end{abstract}

2a Parte: O que aconteceu com Amina? Depois de um outro recurso, Amina foi absolvida e a sentença de morte por apedrejamento foi revogada. Os juízes concordaram que ela não tinha tido oportunidade suficiente de defender o seu caso. O governo nega que ela tivesse sido condenada à morte por apedrejamento. Ela voltou a casar-se. 


\section{estudo de caso sobre direitos sexuais e reprodutivos}

\section{FÁTIMA}

1ạ Parte: História de Fatima: Fatima, uma rapariga de 11 anos da África Ocidental, ouviu os pais a discutir a sua circuncisão. Ela ficou assustada porque se lembrou de como a sua irmã mais velha tinha regressado da cerimónia - cheia de dores e a sentir-se infeliz. Também pensou nas suas melhores amigas que tinham ido várias vezes à clínica local com graves infecções provocadas pela circuncisão. Ela não queria passar por tudo isso e rogou aos pais que não a obrigassem a fazer a circuncisão. Eles mostraram-se relutantes em atender ao pedido da filha porque acreditavam que ela não conseguiria casar-se se não estivesse circuncidada e eram de opinião que a escolha não devia ser feita por alguém tão jovem e inexperiente. Contudo, a irmã de Fatima tinha ouvido falar de uma organização na cidade que trabalhava na educação das famílias locais sobre os perigos e os riscos à saúde decorrentes da mutilação genital feminina (MGF). Ela pediu a um elemento da organização que fosse à palhota da família para falar com os pais sobre a situação de Fatima.

\section{2a Parte: O que aconteceu com Fatima: O} trabalhador da organização convenceu os pais de Fatima de que a circuncisão era perigosa para a saúde da sua jovem filha e que havia outras formas de assinalar o rito importante da sua passagem para a feminilidade. Hoje, Fatima é feliz no seu casamento e grata aos pais por terem mostrado uma mente aberta. Ela trabalha para a mesma organização que a ajudou a evitar a MGF, educando as raparigas na escola sobre como conversar com os pais acerca da circuncisão.

\section{MATTHEW}

1a Parte: História de Matthew: Matthew era um estudante universitário homossexual nos Estados Unidos. Uma noite, dois homens jovens fingiram que eram gays e ofereceram-lhe boleia de casa até um bar. Matthew foi com eles, mas foi levado para uma zona remota, assaltaram-no, amarraram-no a uma vedação, espancaram-no brutalmente com um revólver e torturaram-no. Deixaram-no ali para morrer. Matthew foi encontrado 18 horas depois, ainda amarrado à vedação, por um ciclista que primeiro pensou que se tratasse de um espantalho. Matthew ainda estava vivo, mas em coma.

\section{2a Parte: O que aconteceu com Matthew? O} crânio de Matthew estava fracturado e o cérebro gravemente afectado. Os seus ferimentos eram tão graves que os médicos nada podiam fazer. Não voltou a recuperar a consciência e morreu cinco dias depois. Os assassinos foram presos e cada um recebeu duas penas consecutivas de prisão perpétua. A história de Matthew suscitou atenção nacional aos crimes de ódio. Foi publicada uma lei em nome de Matthew que alarga a legislação sobre crimes de ódio de modo a incluir crimes de ódio contra gays e lésbicas, mulheres e pessoas portadoras de deficiência. A mãe de Matthew criou a Fundação Matthew Shepard, que procura "substituir o ódio pela compreensão, compaixão e aceitação" através da educação, divulgação e advocacia. 


\section{estudo de caso sobre direitos sexuais e reprodutivos}

\section{LAKSHMI}

1a Parte: História de Lakshmi: Lakshmi, uma jovem rapariga do Nepal, foi forçada a casar-se com 12 anos e foi explorada em casa do marido. Por já não conseguir suportar a sua situação, fugiu e regressou à casa dos pais, mas estes obrigaram-na a regressar ao lar conjugal. "Pelo caminho consegui escapar e uma senhora bondosa ajudou-me," afirmou Lakshmi. "Ela disse que a irmã estava a trabalhar numa fábrica numa outra zona do Nepal e que eu podia juntarme a ela; tudo o que era necessário fazer era vender a roupa da fábrica". Mas no caminho, Lakshmi foi drogada e levada para a Índia. Lakshmi disse "Foi aí que me apercebi que tinha sido vendida por 15.000 rupias indianas. Fui espancada quando me recusei a ser trabalhadora do sexo. Durante um ano, fiquei trancada num bordel. Mais tarde, a polícia invadiu o bordel e eu fui resgatada e enviada de volta ao Nepal. Nessa altura eu tinha 14 anos de idade.”

2a Parte: O que aconteceu com Lakshmi? Quando Lakshmi regressou, os pais recusaram-se a aceitála. Mais tarde, ela casou-se, mas constatou que era seropositiva. Não está claro se ela contraiu o vírus quando foi forçada a ser trabalhadora do sexo ou depois de se casar. 


\section{teias de palavras sobre masculinidade $e$ femininidade}

DURACÃO:

45 minutos

\section{MATERIAL:}

Quadro + giz

\section{PREPARAC̄̃̃:}

Decidir se pretende acrescentar quaisquer características que sejam particularmente adequadas à sua comunidade.
VISÃO GERAL: Os alunos trabalham em grupos para criar teias de palavras relacionadas com o que a sociedade diz sobre o que significa ser um "homem" ou uma "mulher" e discutir a proveniência destas ideias. É-lhes apresentado o conceito de género.

OBJECTIVOS:Permitir que os alunos definam "género" e que distingam entre as características atribuídas aos indivíduos do sexo masculino e feminino que são biológicas e quais as que são determinadas socialmente; fortalecer o pensamento crítico e habilidades de escrita criativa.

\section{INSTRUCCÕES}

1 Divida os alunos em grupos de quatro ou cinco (de um único sexo, ou não).

2 Explique:

- Hoje vamos discutir o tema género (o que a sociedade diz que significa ser um homem ou uma mulher). Cada grupo deve criar teias de palavras que são muitas vezes associadas ao facto de ser um homem ou uma mulher.

Para esclarecer o conceito de "teia de palavras," poderá dar um exemplo no quadro de uma teia de palavras sobre um outro assunto. Ver o exemplo da palavra "cão", a seguir.

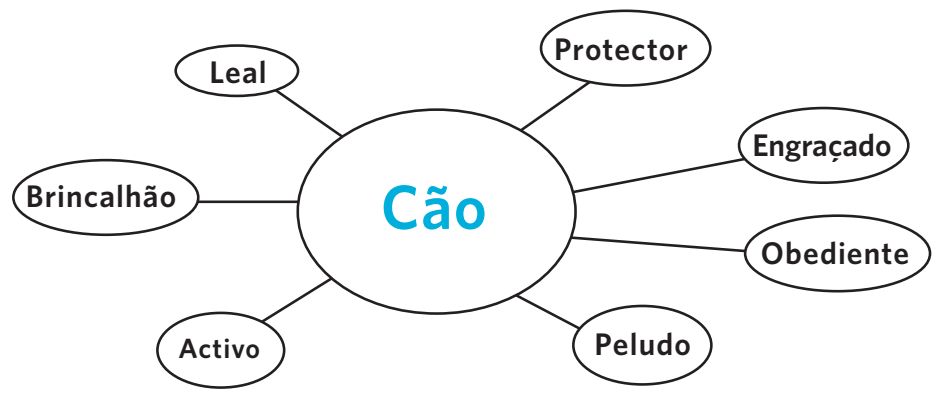

3 Dê a cada grupo de alunos dois a três minutos para criarem uma teia de palavras relacionadas com "homem" e outros dois a três minutos para "mulher."

4 Escreva "Mulher" e "Homem" no quadro e faça duas colunas debaixo de cada palavra, uma com o título "biológico" e a outra com o título "social." Começando por um grupo de alunos, pergunte:

- Qual a característica da vossa teia de palavras associada ao facto de ser homem?

- Essa característica é determinada biologicamente ("Biológica") ou é determinada socialmente ("Social”)?

- Se os estudantes atribuírem uma característica "social" à categoria "biológica", corrija-os perguntando: Se um rapaz ou homem não possuir essa característica, continua a ser do sexo masculino? 
5 Acrescente uma nova característica à lista de cada grupo de alunos até obter todas as respostas referentes a ser homem. Certifique-se de que os alunos têm muitas das seguintes palavras nas suas teias. (Poderá ter que fazer perguntas de sondagem para gerar respostas específicas). Alguns exemplos comuns do que as pessoas associam a "ser homem" incluem:

- Fisicamente forte

- Emocionalmente não expressivo

- Um predador sexual

- Heterossexual

- Financeiramente bem-sucedido

- Responsável por uma família

- Calmo, controlado

- Ser pai

- Orgulhoso

- Poderoso

- Atlético

- Bravo

- Sem medo de violência ou de usar a violência

- Com sentido de humor

- Leal aos amigos

6 Repita este processo para as características associadas com "ser uma mulher." Alguns exemplos comuns:

- Ponderada

- Tranquila

- Submissa

- Conversadora

- Uma boa comunicadora

- Bem preparada

- Emocionalmente forte

- Bem organizada / boa na realização de várias tarefas ao mesmo tempo

- Prática
- Não violenta

- Modesta

- Com curvas

- Fisicamente mais fraca do que o homem

- Atenciosa

- Mãe

7 Reserve dez minutos em discussão de todo o grupo:

- Algumas características de indivíduos do sexo masculino e feminino são biológicas. Por exemplo, apenas os homens podem ser pais; apenas as mulheres podem dar à luz ou amamentar.

- Mas a maior parte das características associadas com o sexo masculino ou feminino são determinadas socialmente - não com base na biologia.

- Os papéis masculinos e femininos que são determinados socialmente são chamados papéis de género. Quem já tinha ouvido falar deste termo?

- Que sentimentos têm em relação aos papéis de género na nossa sociedade? Concordam com todos os aspectos de como se espera que os indivíduos do sexo feminino actuem e vivam? Como é que os do sexo masculino devem agir?

- O que pensam que igualdade de género significa?

- Em qualquer comunidade e sociedade, algumas pessoas mantêm atitudes em relação ao género e igualdade que não são convencionais.

- Uma vez que a sociedade muda com o tempo ou de região para região, também mudam as atitudes em relação aos papéis de género.

Traballho de Casa: Conclua e expanda a seguinte afirmação, na forma de lista, carta ou poema: "Não é fácil ser uma rapariga / um rapaz porque..."
Adaptado de What's the Real Deal About Masculinity? (2008. Scenarios USA.) 


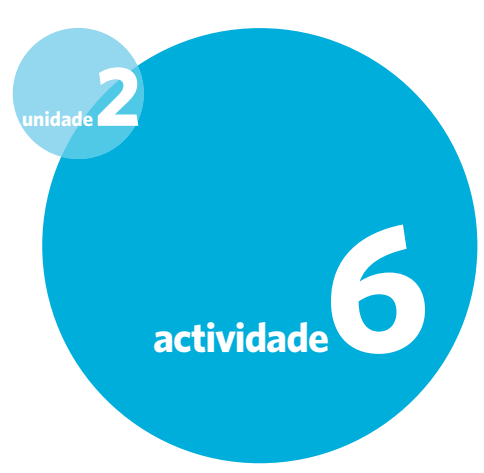

DURAC̣ÃO:

45 minutos (A Etapa 5 pode ser dada como trabalho de casa.)

\section{MATERIAL:}

Quadro + giz

\section{PREPARAC̄̃O:}

Percorra você mesmo esta viagem de memórias antes de realizar a actividade. As actividades de memórias podem desencadear sentimentos difíceis para alguns alunos. Pense em como melhor responder - e a quem poderá recorrer- caso qualquer aluno necessite de mais apoio.

\section{viagem de memórias: aprender sobre o género enquanto crianças}

VISÃO GERAL: Os alunos partilham uma memória de um tempo em que tenham sido tratados de uma certa maneira por causa do seu sexo; recordam os seus sentimentos sobre estas experiências.

OBJECTIVOS: Permitir que os alunos analicen e dêem exemplos de como as crianças absorvem as mensagens sobre os papéis de género; considerar estas mensagens sob uma perspectiva pessoal e de direitos humanos; fortalecer as suas habilidades de pensamento crítico.

\section{INSTRUCÕ̃ES}

1 Divida a turma em grupos de um único sexo constituídos por quatro a cinco elementos por grupo. Peça que tragam papel e caneta.

2 Explique:

- Hoje vamos explorar o que significa crescer como rapaz ou como rapariga. Primeiro, vamos fazer uma pequena viagem pelas nossas memórias, pelo que instalem-se confortavelmente, pousem as vossas canetas e relaxem.

- Pensem numa altura em que se aperceberam que estavam a ser tratados de uma certa maneira por causa do vosso sexo. À medida que se forem lembrando de alguma coisa, vão escrevendo.

- Que sentimentos surgem ao se lembrarem dessa experiência? Anotem essas emoções. Terão a opção de partilhar a memória (ou não) no vosso pequeno grupo.

3 Passados alguns minutos, pergunte:

- Dentro do vosso grupo, partilhem durante alguns minutos o que quiserem sobre as vossas experiências ou sentimentos. Não têm que partilhar se não quiserem.
4 Depois de passarem mais 5-10 minutos, pergunte:

- O que estas experiências vos dizem acerca das atitudes e normas sociais referentes ao valor e aos papéis das raparigas e das mulheres? E dos rapazes e dos homens?

- Pensando de novo no que aprendemos acerca dos direitos humanos, estas atitudes e normas parecem-vos justas? Porquê ou porque não?

- Quais são algumas mudanças que teriam que ser feitas para se conseguir a igualdade entre indivíduos do sexo masculino e feminino?

5 [Nota: Se não houver tempo, esta etapa pode ser dada como trabalho de casa.] Lembre aos alunos que qualquer situação pode ter vários resultados. Dê-lhes uma oportunidade para mudarem o fim de uma história, explicando:

- Voltem para uma memória de uma situação que acham que foi injusta - aquela sobre a qual escreveram ou outra que tenham ouvido no vosso grupo.

- Escrevam um novo fim para a história, que vos pareça mais justo. 


\section{imagens de paternidade}

VISÃO GERAL: Os alunos escrevem sobre os seus pais ou sobre um cuidador do sexo masculino. Discutem como os papéis de género limitam os homens como cuidadores. Escrevem sobre o tipo de pai que esperam vir a ser ou ter para os seus próprios filhos (ou para crianças que conheçam).

OBJECTIVOS: Permitir que os alunos avaliem experiências e valores sobre os cuidados prestados pelos homens; fortalecer a reflexão pessoal e habilidades de escrita.

\section{INSTRUÇÕES}

1 Introduza o tópico explicando o seguinte:

- Hoje vamos discutir a paternidade e modelos masculinos.

- Gostaria que todos começassem por escrever uma pequena carta ao vosso pai, ou encarregado de educação, ou qualquer outra figura de pai significativa na vossa vida. Não terão que divulgar o conteúdo da vossa carta. Comecem a vossa carta com uma das seguintes frases:

Querido Pai, deve pensar que me esqueci, mas lembro-me que...

Querido Pai, eu preciso de...

2 Passados cerca de cinco minutos, pergunte:

- Que tipo de pessoa é o seu pai, ou essa figura paterna, na sua vida? Escreva pelo menos dez adjectivos que o descrevem. Mais uma vez, o que escreverem é um assunto particular, pelo que não tem que ser divulgado.

- Agora enumerem dez adjectivos que gostariam de ver incluídos no papel de pai que achem que fazem parte de ser um pai maravilhoso.
- Olhem para a vossa segunda lista de adjectivos. Assinalem os adjectivos que descrevem a maior parte dos pais. Desenhem um círculo à volta dos adjectivos que são pouco comuns ou que descrevem poucos pais.

- Os homens acham que os papéis masculinos tradicionais dificultam ou facilitam a maneira como os seus filhos queriam que eles se comportassem?

- Podem dar um exemplo de um pai ou figura de pai que aja de uma maneira que desafia os papéis de género tradicionais?

3 Para concluir, pergunte: Como gostariam que a paternidade mudasse no futuro?

Trabalho de Casa: Entrevistar um homem adulto que conheçam. Pedir-lhe para falar sobre o que considera boas qualidades num pai.

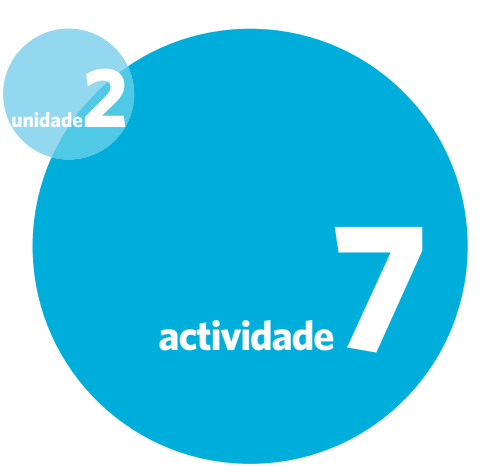

DURAC̣ÃO:

45 minutos

\section{MATERIAL:}

Quadro + giz

\section{PREPARACÃO:}

Escrever as perguntas e as frases referentes à Etapa 1 no quadro, ou colocá-las em formato de ficha. Pensar no impacto emocional que esta actividade pode ter em alguns alunos (especialmente nos que têm sentimentos ambivalentes ou negativos em relação aos seus pais, ou que não têm pai em casa). Não realizar esta actividade, a menos que haja condições para oferecer aos alunos apoio adequado, caso seja necessário. 


\section{projecto de pesquisa: género no ambiente escolar}

DURACÃO:

Etapas 1-5: 40 minutos

\section{Etapa 6: 4 a 5 horas}

Etapas 7-8: 90 a 120 minutos

\section{MATERIAL:}

Quadro + giz; cópias das fichas

do aluno; fita-cola.

\section{PREPARAC̄̃̃O:}

Obter autorização da direcção

da escola para os alunos

realizarem esta pesquisa.

Escrever cada tópico da Etapa 2 num pedaço de papel diferente. (Se for necessário, modificar a lista de tópicos para que sejam relevantes e viáveis no contexto da sua escola). Decidir como irá atribuir os tópicos da Etapa 3 aos alunos. Se for possível, fazer cópias da ficha para cada aluno.
VISÃO GERAL: Os alunos fazem uma pesquisa sobre o papel do género na escola e apresentam os seus resultados. Este projecto requer pesquisa fora da aula e tempo na sala de aula.

OBJECTIVOS: Permitir que os alunos analisam em grupo como o ambiente escolar pode reforçar ou desafiar as normas de género tradicionais; fortalecer as habilidades de pesquisa.

\section{INSTRUÇÕES}

1 Colar cada folha (com os tópicos da pesquisa) num canto ou local diferente da sala.

2 Explique:

- Vão fazer alguma pesquisa ao longo da próxima semana. A questão a que a pesquisa deve procurar responder é "Como é que as escolas reforçam ou desafiam os papéis de género tradicionais?"

- Cada uma das quatro equipas de pesquisa deve olhar para um dos seguintes temas: comportamento na sala de aula, actividades escolares extracurriculares, programa e livros, $e$ estatísticas escolares e da educação.

- Tentem identificar dois tópicos que sejam do vosso interesse.

3 Para constituir as equipas de pesquisa, peça aos alunos que assinem a folha com o tópico do seu interesse. (Ou afecte-os a equipas).

4 Circule e analise as Instruções de Pesquisa. Certifiquese de que todos entendem como proceder.

5 Entregue a cada equipa a sua respectiva ficha. Peça aos grupos que discutam como irão realizar a sua pesquisa. Circule pela sala e dê orientações adicionais, caso seja necessário.
6 Explique aos alunos que têm duas semanas para completar a pesquisa. Continue a dar o apoio que for necessário durante as duas semanas.

7 No fim da fase de pesquisa, peça aos alunos que apresentem os seus trabalhos e constatações. Dê 15 minutos para cada apresentação. Depois de cada apresentação, pergunte aos outros alunos:

- Têm alguma pergunta a fazer a esta equipa?

- O que mais vos interessou ou surpreendeu?

- Concordam com as suas conclusões? Se não, porquê?

- Que outras recomendações gostariam de apresentar?

8 Assim que todas as equipas tiverem apresentado, pergunte à turma:

- De que forma o ambiente escolar reforça as normas de género tradicionais?

- De que forma as desafia?

- Quais são as cinco mudanças que tornariam a escola mais justa em termos de género e mais acolhedora, respeitosa e segura para todos?

- O que podem fazer para que isto se torne uma realidade? 


\section{instruções para todos os grupos de pesquisa}

O tópico para o projecto de pesquisa da turma é o seguinte: "O papel do género no ambiente escolar." Cada equipa deve realizar uma pesquisa sobre um aspecto diferente deste tópico. Estas são as etapas a seguir:

1 Rever com atenção as perguntas com a sua equipa.

2 Discutir a melhor forma de encontrar respostas para as perguntas. Se necessário, pedir ajuda ao professor.

3 Decidir se cada membro da equipa se responsabilizará por perguntas diferentes, ou se os membros devem colaborar na pesquisa de certas perguntas.

4 Recolher a informação necessária para responderem às vossas perguntas. Pedir ajuda, se for necessário.

5 Assim que os vossos dados tiverem sido recolhidos, elaborar um relatório com as seguintes secções:

a $\mathrm{A}(\mathrm{s})$ pergunta(s) a que tentaram responder

b Métodos de pesquisa (como a pesquisa foi realizada)

c Resultados (o que aprenderam)

d Conclusão (o que acham dos resultados, que conclusões tiraram)

e Recomendações (mudanças que poderiam tornar o ambiente escolar mais justo em termos de género e um local mais acolhedor e seguro, tanto para as raparigas como para os rapazes)

A sua equipa também deve fazer uma apresentação de 15 minutos com base no seu relatório. Planificar a apresentação. Garantir que todos os membros da equipa estejam envolvidos na apresentação. 


\section{FICHA DA EQUIPA 1:}

Acham que os nossos livros reflectem uma tendência a favor de um sexo? Ou promovem a igualdade de género?

\section{Exemplos de perguntas:}

- Como é que as raparigas e os rapazes e os homens e as mulheres são retratados nos nossos livros?

- Quantas mulheres e quantos homens se mostram nas figuras?

- As realizações históricas, intelectuais, científicas, literárias e artísticas das mulheres são totalmente representadas?

- Em histórias e na literatura quem age? Quem é subordinado?

- De quem é o ponto de vista que o livro reflecte? O autor do livro é do sexo masculino ou feminino?

- De que outras maneiras os estereótipos de género estão reflectidos e são reforçados ou desafiados?

- Que outros grupos estão estereotipados no livro?

\section{Métodos de pesquisa:}

Usar pelo menos dois livros, por exemplo, de ciências sociais, história ou literatura, utilizados no ensino primário ou secundário. Analisar o conteúdo e as imagens para responder às perguntas acima exemplificadas.

\section{FICHA DA EQUIPA 2:}

De que maneira o ambiente na sala de aula reforça ou desafia os papéis de género convencionais?

\section{Exemplos de perguntas:}

- Quem fala mais na sala, os rapazes ou as raparigas? Quem fala mais tempo? Quem interrompe mais frequentemente? Se houver dirigentes dos alunos na sala, são do sexo masculino ou feminino?

- De que maneira os professores desafiam-ou reforçam - padrões de comportamento de género?

- Alguns alunos são favorecidos ou desfavorecidos em resultado de outros estereótipos, por exemplo, sobre a sua etnicidade ou identidade sexual?

\section{Métodos de pesquisa:}

Observar várias aulas, de preferência com professores diferentes. Antes de observar, discutir com a sua equipa como devem "medir" e documentar o que vêem. Poderão desenvolver um formulário simples que poderão preencher enquanto observam. Se tiverem acesso a um relógio, poderão cronometrar durante quanto tempo os diferentes alunos do sexo masculino ou feminino falam. 


\section{FICHA DA EQUIPA 3:}

De que forma as normas de género afectam a utilização de programas extracurriculares e das instalações existentes na escola?

\section{Exemplos de perguntas:}

- Os rapazes e as raparigas participam de igual forma em todas as actividades extracurriculares? Se tendem a participar em actividades diferentes, quais as que envolvem mais rapazes? Quais as que envolvem mais raparigas?

- No geral, mesmo que participem em actividades diferentes, a probabilidade de os rapazes e as raparigas participarem em programas extracurriculares é igual?

- A escola aloca acesso igual a instalações (tais como casas de banho, ginásios, campos de jogo, etc.), equipamento, uniformes e artigos para as actividades que envolvem raparigas e para as que envolvem rapazes?

- No caso das actividades que envolvem tanto rapazes como raparigas, quem normalmente assume o papel de liderança?

\section{Métodos de pesquisa:}

Elaborar uma lista de todas as actividades extracurriculares dos estudantes na escola, tais como o desporto, a administração dos alunos, clubes escolares, etc. Observar a actividade, entrevistar alunos do sexo masculino e feminino que estejam envolvidos e entrevistar um professor - conselheiro do grupo.

\section{FICHA DA EQUIPA 4:}

Qual é o equilíbrio de género geral da escola? $\mathrm{O}$ que os dados estatísticos nos dizem sobre esta situação?

\section{Exemplos de perguntas:}

- Os professores são, na sua maioria, do sexo masculino ou feminino? E o director /reitor da escola? Que professores (do sexo masculino ou feminino) têm uma melhor hipótese de promoção a director /reitor?

- A probabilidade de homens e mulheres ensinarem matemática é a mesma? E literatura? Arte?

- Quem ensina as primeiras classes? E as classes mais avançadas?

- E os alunos? As raparigas e os rapazes estão matriculados em níveis iguais? Se não, porquê?

- As raparigas e os rapazes apresentam a mesma probabilidade de ingressarem em todas as turmas? Sentir-se-iam acolhidas da mesma maneira em todas as turmas?

\section{Métodos de pesquisa:}

É possível que o director /reitor da sua escola possa fornecer grande parte da informação específica ao género de que necessitem. Caso não, falem com o maior número possível de professores sobre as suas turmas e sobre a faculdade no departamento em que leccionam. Se for possível, recolham dados nacionais sobre como as normas de género afectam o aproveitamento escolar, incluindo as classes concluídas. 


\section{venda de estereótipos: uma análise da publicidade}

\section{DURAÇÃO:}

40 minutos

\section{MATERIAL:}

Quadro + giz; revistas ou jornais com anúncios publicitários; tesouras, papel grande, cola ou fita-cola.

\section{PREPARAC̄̃̃:}

Juntar revistas e jornais suficientes com anúncios publicitários para todo o grupo ou pedir aos alunos que tragam revistas que possam recortar.
VISÃO GERAL: Os alunos fazem uma colagem de imagens de pessoas do sexo feminino e masculino retiradas de anúncios publicitários, analisam as mensagens desses anúncios referentes ao género e criam anúncios que quebram os estereótipos.

OBJECTIVOS: Que os alunos reconheçam e descrevam o papel que da imprensa escrita na criação e perpetuação de estereótipos de género; fortalecer as habilidades de pensamento crítico.

\section{INSTRUÇÕES}

1 Distribua as revistas e explique:

- Vamos fazer colagens - arte feito de figuras que vão recortar de revistas e colar numa folha de papel.

- Cada um deve criar duas colagens. Uma deve mostrar imagens de mulheres/raparigas e a outra colagem imagens de homens/rapazes.

2 Dê 10-15 minutos para terminarem as colagens e em seguida descreverem o resto do projecto:

- Começando pela colagem de imagens de homens, façam uma lista no vosso caderno das características dos homens que vêem nos anúncios publicitários.

- Façam o mesmo com a colagem de mulheres.

3 No quadro, desenhe dois círculos sobrepostos e um deve ser intitulado "masculino," o outro "feminino" e a secção sobreposta com "ambos". Perguntar:

- Que características aparecem só nos anúncios dos homens? [Enumerá-las no círculo "masculino".]

- Que características estão apenas nos anúncios das mulheres? [Enumerá-las no círculo "feminino".]

- Algumas características foram apresentadas tanto nos anúncios femininos como nos masculinos? [Enumerá-las na parte sobreposta dos círculos.]
- Que notam em relação a este diagrama? Que ideia os anúncios promovem em relação à maneira como as mulheres se devem comportar ou sobre a sua aparência? E em relação aos homens?

- De que maneira estas imagens criam ou reforçam os estereótipos de género? Que valores vendem às mulheres? E aos homens?

- Como estas imagens se comparam a realidade?

- Em que ponto é que as imagens dos órgãos de informação se tornam estereótipos? Os órgãos de informação criam novos estereótipos ou simplesmente repetem ou reforçam os estereótipos que já são comuns na sociedade? Porquê?

- De que forma os jovens são influenciados pelas imagens nos órgãos de informação? Já alguma vez se sentiram mal convosco próprios depois de olharem para uma revista ou anuncio na televisão? $\mathrm{O}$ que as pessoas podem fazer se acharem que os anúncios publicitários são ofensivos ou caso se oponham às imagens estereotipadas que retratam?

Trabalho de Casa: Criar um anúncio alternativo que rompa com os estereótipos sobre o género. [Pedir que pendurem o trabalho na parede ou o apresentem aos colegas.] 


\section{espaço de acordo com o género}

VISÃO GERAL: Os alunos desenham mapas das suas comunidades, mostrando que espaços são seguros e acessíveis às pessoas de cada sexo. Devem analisar como a participação na vida cívica é afectada pelos papéis de género. (Nota: o instrutor deve decidir se esta actividade é, ou não, relevante para a sua comunidade.)

OBJECTIVOS: Permitir que os alunos analisem de que maneira o género afecta a mobilidade, a segurança e o acesso aos espaços da comunidade; indicar pelo menos três formas em que as normas de género podem afectar a participação das raparigas e das mulheres na vida cívica; fortalecer as habilidades de pensamento abstracto e de representação geográfica de dados.

\section{INSTRUC̣ÕES}

1 Explique aos alunos que vão fazer "mapas de género" da comunidade que mostrem que lugares ou espaços fora de casa se destinam essencialmente aos homens e rapazes (onde realizam os seus encontros, brincam/jogam ou se envolvem noutras actividades em segurança); que lugares se destinam essencialmente às mulheres e raparigas; e quais são os lugares para ambos.

2 Divida os alunos em pequenos grupos (de um único sexo ou não) e dê a cada grupo uma cópia do mapa geral da sua comunidade. (Para os grupos avançados, poderá dar mais algum tempo e pedirlhes que elaborem o seu próprio mapa.)

3 Dê aos alunos um conjunto de três lápis de cor (ou marcadores) e uma lista dos seguintes lugares da sua comunidade. (Para os grupos avançados, poderá pedir-lhes que produzam a sua própria lista de lugares.)

\section{LISTA DE LUGARES}

Mercado de produtos alimentares

Locais de culto

Escola

Centro comunitário

Biblioteca

Sala de jogos

Cinema

Ruas da cidade / vila à noite

Cafés

Recintos desportivos / campos de basquetebol Bares

Estação de comboio / paragem de autocarros / aeroporto

Conselho municipal / edifícios municipais

Local de lavagem de roupa (lavandaria / rio)

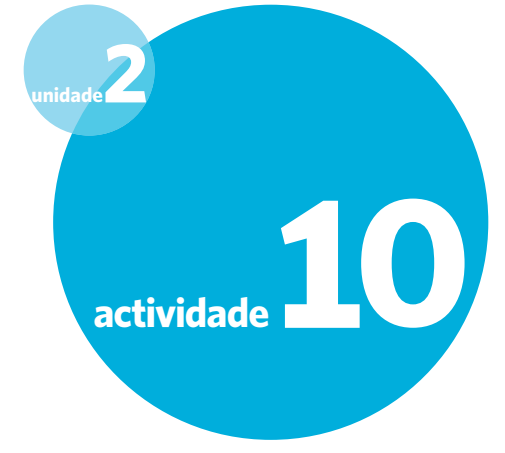

\section{DURACÃO:}

Etapas 1-5: 45 minutos (mais tempo, caso se pretenda que os grupos façam os seus próprios mapas e produzam a sua própria lista de lugares)

\section{Etapas 6-7: 45 minutos}

\section{MATERIAL:}

Quadro + giz; fita-cola; cinco ou seis cópias de mapas simples da sua comunidade que seja possível obter com antecedência (ou folhas de papel grandes para os alunos de nível avançado utilizarem na elaboração dos seus próprios mapas); lápis de cor ou canetas coloridas.

\section{PREPARAC̄̃O:}

Rever a lista dos lugares e modificá-la de modo a reflectir a sua comunidade. 
4 Descreva o projecto:

- Discutam de forma resumida no vosso grupo se cada lugar é visitado essencialmente por homens e rapazes, por mulheres e raparigas, ou por ambos da mesma forma. Considerar se os lugares são acolhedores e seguros.

- Escolham um lápis ou marcador de uma cor para os locais mais acolhedores para os homens, outra cor para os locais mais acolhedores para as mulheres e uma terceira cor para pessoas do sexo masculino e feminino. Identifique cada local no mapa, usando a cor que indica a natureza de "género" desse lugar.

- Depois de terminarem, discutam o que o vosso mapa indica sobre a mobilidade, a segurança e o acesso a espaços públicos da comunidade.

5 Circule pelos grupos enquanto preenchem os mapas e dinamize as suas discussões.

6 Peça aos estudantes que pendurem os seus mapas na parede. Cada grupo apresenta o seu mapa, ou então todos circulam e olham para cada mapa.

7 Pergunte a todo o grupo (e coloque as suas respostas no quadro):

- Quais foram algumas das vossas observações? As raparigas têm a mesma mobilidade que os rapazes? Como se pode comparar as raparigas e os rapazes em termos de acesso aos espaços públicos?
- A segurança em público é a mesma para rapazes e raparigas?

- Estas condições mudam quando os rapazes são mais crescidos? E quando as raparigas são mais crescidas?

- Quais são algumas razões comuns apresentadas para a existência destas diferenças?

- Como se sentem em relação à natureza de género do espaço público?

- Para participarem activamente na vida cívica, de que acesso aos espaços públicos as pessoas necessitam?

- De que forma o acesso limitado das raparigas e das mulheres afecta a sua capacidade de serem cidadãos plenos? [Perguntar aos estudantes: Quantas mulheres conhecem que ocuparam cargos decisórios? Quantas mulheres têm poder público comparativamente aos homens? O governo local está a cargo de homens ou de mulheres?]

- Os rapazes e os homens são afectados da mesma maneira? Porquê ou porque não?

Trabalho de Casa: Escolher um lugar onde as mulheres e as raparigas não se sintam seguras nem bem-vindas. Descrever o que deveria ser feito para mudar essa situação. Como é que uma tal mudança poderia acontecer? 


\section{mulheres de acção: projecto "faça um livro"}

VISÃO GERAL: Os alunos criam livros infantis sobre uma líder do sexo feminino. (Esta actividade requer acesso a uma biblioteca ou à Internet, pelo que se deve planificar em conformidade.)

OBJECTIVOS: Que os alunos conheçam líderes do sexo feminino e conseguir relacionar a coragem e as realizações das mulheres com as suas próprias vidas; fortalecer as habilidades de pesquisa.

\section{INSTRUÇÕES}

1 Distribua a ficha (ou copie no quadro).

2 Divida a turma em grupos de três ou quatro estudantes e explique:

- Hoje vamos começar um projecto que envolve a aprendizagem sobre as mulheres que foram ou são líderes da causa de justiça social.

- Cada grupo deve pesquisar a vida e o trabalho de uma heroína diferente.

- Em seguida, cada grupo deve escrever uma história infantil sobre essa heroína e encaderná-la num livro infantil. [Mencionar quaisquer arranjos que tenha feito para que os alunos emprestem ou leiam os livros às crianças numa escola primária situada nas proximidades.]

3 Reveja a lista de Mulheres de Acção (ver a ficha). [Explicar como devem escolher ou como se thes deve ser atribuída a sua "Mulher de Acção" para evitar situações de duplicação.] Perguntar:

4 Reveja as Perguntas Orientadoras (consultar a ficha ou pedir que os alunos copiem as perguntas do quadro).

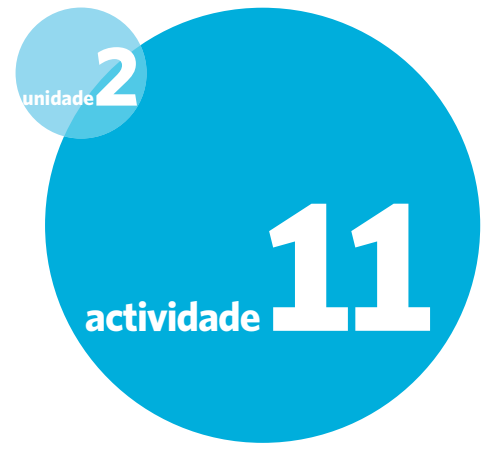

DURAC̄̃O:

Etapas 1-7: 45 minutos

Implementação: 2-3 horas, na sala de aula ou como trabalho de casa

Paso 8: 45 minutos

na aula ou em casa; 2) quantos dias têm para concluí-lo e entregá-lo e 3) onde podem obter informação sobre a sua Mulher de Acção.

6 Explique que quando a pesquisa tiver terminado, cada elemento do grupo será responsável por pelo menos um aspecto do processo de produção do livro: escrever a história; editar e rever; criar ilustrações, conceber e fazer as capas; encadernar o livro (coser, colar, agrafar, etc.).

7 Use o tempo restante para cada grupo seleccionar a sua "Mulher de Acção" e para delegar tarefas de produção do livro dentro do grupo (ver ficha). Circule para dar apoio durante o processo.

8 Apresentação dos livros completos: Peça a cada grupo que leia o seu livro em voz alta aos colegas e, se possível, a crianças mais novas. Em seguida, pergunte:

- Que mulher admiraram de maneira particular?

- Acham que poderiam fazer alguma coisa semelhante ao que qualquer uma destas heroínas fez?

- O que é que isso implicaria?

\section{MATERIAL:}

Papel; marcadores; agulha / linha, fita-cola, agrafador, outros materiais para fazer um livro; ficha "Instruções do Projecto Fazer um Livro".

\section{PREPARAC̄̃O:}

Rever a lista Mulheres de Acção correcto ensinar sobre todas as mulheres da lista no vosso contexto. Preparar uma lista suficientemente longa para que cada grupo pequeno uma mulher diferente sobre a qual aprender. Se for possível, fotocopiar a ficha para distribuir pelos alunos. Considerar a possibilidade de contactar uma escola primária para perguntar se os alunos poderiam visitá-la e ler os livros que tiverem concluído às crianças mais novas. na ficha do aluno para que seja de três ou quatro elementos tenha 


\section{mulheres de acção: instruções do projecto "fazer um livro"}

\section{MULHERES DE ACC̣ÃO}

\section{Graça Machel}

Política e activista moçambicana dos direitos humanos

\section{Rosa Parks}

Líder americana dos direitos civis

\section{Mukhtaran Bibi}

Líder paquistanesa contra a

violência sexual

\section{Leymah Gbowee}

Líder do movimento de paz em

Liberia

\section{Wangari Maathai}

Líder dos assuntos ambientais do Quénia

\section{Michelle Bachelet}

Líder política do Chile

\section{Arundhati Roy}

Escritora indiana

\section{Sophie Scholl or Martha}

Wertheimer

Resistentes contra o nazismo

\section{Hillary Clinton}

Líder política dos Estados Unidos

Vera Ngassa or Beatrice Ntuba Juízas camaronesas

\section{Nadia Murad}

Activista yazidi-iraquiana dos

direitos humanos
Perguntas orientadoras de pesquisa para o vosso livro sobre um líder do sexo feminino:

1 Qual é nome da mulher?

2 Qual é um factor chave sobre seus primeiros anos de vida?

3 Que problema social ela observou? Como é que chegou a reparar nele?

4 Como é que sabem que ela se preocupava com este problema?

5 O que ela fez para resolver o problema?

6 Alguém a ajudou?

7 Contem uma história sobre uma altura em que ela teve que recorrer a uma qualidade pessoal que admiram. Esta qualidade pode ser coragem, firmeza, integridade, paciência, criatividade, inteligência, capacidade de se relacionar bem com as outras pessoas, visão do futuro ou uma outra qualidade.

8 Descrevam como o mundo é diferente por causa das suas acções.

9 Incluam uma citação dela, se for possível.

10 Dêem um título ao vosso livro que seja mais do que apenas o seu nome, um título que também se refira à questão que mais a preocupava ou algo interessante sobre as suas qualidades pessoais que tenham aprendido.

Preencham o nome da pessoa no vosso grupo que deve...

Ajudar a escrever a história (pode ser mais do que uma pessoa):

Editar a história:

Rever o texto:

Ilustrar a história:

Conceber e criar as capas do livro:

Compilar e encadernar o livro: 


\section{alterar o corpo}

VISÃO GERAL: Os alunos identificam a aparência idealizada para homens e para mulheres na sua cultura e analisam as práticas em que as pessoas se envolvem para adaptar a sua aparência a este ideal. Aprendem sobre as consequências destas práticas na sua saúde.

OBJECTIVOS: Questionar as pressões para se adaptar à aparência "ideal" ditada pela cultura; descrever práticas a que as pessoas (em especial as mulheres e as raparigas) se submetem ao tentar conseguir essa aparência e os danos que tais práticas podem causar; fortalecer as habilidades de pensamento crítico.

\section{INSTRUC̣ÕES}

1 Introduza o tópico com as seguintes perguntas:

- Quais são algumas das pressões que os/as jovens sentem para terem uma determinada aparência?

- Estas aparências desejadas são realistas para a maior parte de nós, ou são idealizadas?

- Como é que as pessoas se sentem se não conseguirem alcançar esse ideal?

- Quais são algumas das coisas que as pessoas fazem (ou a que submetem os seus filhos) para estarem em conformidade com as imagens idealizadas de atracção? Por exemplo, ao cabelo? Pele? Forma do corpo? [Escrever as respostas no quadro.]

2 Acrescente práticas que pretenda discutir, por exemplo: Dieta de engorda ou dieta extrema

Musculação extrema

Bronzear ou clarear a pele

Aplicação de maquilhagem, hena, ou verniz ao unhas

Piercing (furar), escarificação, ou tatuagens

Rapar ou arrancar o cabelo

Desfrisar, encaracolar, ou pintar o cabelo

Cirurgia plástica

Mutilação genital feminina ou circuncisão*

- Qual a importância de pôr termo às práticas

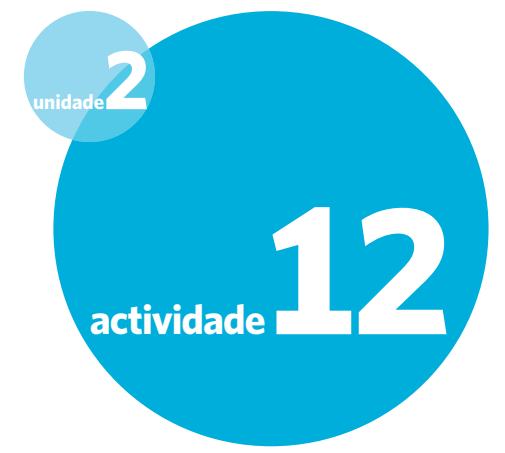

DURAÇÃO:

45 minutos

MATERIAL:

Quadro + giz

3 Pergunte:

- Qual a vossa opinião em relação às práticas contidas nesta lista? Quais as que são lúdicas ou apenas expressivas, e quais é que podem ser prejudiciais?

- O que as pessoas de outras culturas pensariam acerca das práticas aqui enumeradas?

- De onde vêm estas ideais? As mulheres estão sob maior pressão do que os homens para estarem em conformidade com um tipo de corpo idealizado? Quem beneficia e quem é prejudicado neste processo? De que forma esta pressão afecta a auto-estima? prejudiciais que envolvem alterações do corpo? Que prática, caso exista, gostariam que cessasse?

- Quando cresciam, alguém vos disse que esta prática era perigosa e devia cessar?

- Partilharam os vossos próprios conhecimentos e sentimentos em relação a ela com mais alguém?

- Como é que o fariam?

\section{PREPARAC̄̃̃O:}

Pensar em formas que as pessoas - na sua comunidade - usam para mudar a sua aparência. Considerar quais dessas práticas têm consequências para a saúde. Analisar a lista a seguir e ver que práticas quer que a sua turma discuta.

* A circuncisão masculina é também uma prática comum que envolve uma mudança do corpo. Todavia, foi demonstrado que este procedimento traz benefícios à saúde. Proporciona aos homens uma protecção parcial das ITS, incluindo o HIV. 


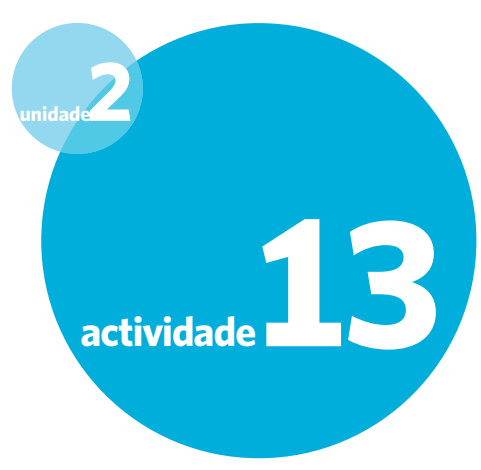

DURAC̄̃O:

90 minutos (pode ser dividida em duas sessões)

\section{MATERIAL:}

Quadro + giz

\section{PREPARAC̣ÃO:}

Pensar e/ou ler sobre a violência no seu contexto. Estar ciente de que falar sobre a violência doméstica é difícil para muitas pessoas por causa das suas experiências pessoais, ou da sua convicção de que é uma questão particular. Nunca colocar os alunos numa situação difícil.

\section{da violência ao respeito em relacionamentos íntimos}

VISÃO GERAL: Os alunos criam peças dramáticas que exploram o respeito e a violência no relacionamento íntimo, discutem como promover o respeito nos seus próprios relacionamentos

OBJECTIVOS: Facilitar que os alunos discutam atitudes sobre a violência no relacionamento íntimo e formas de promover uma relação baseada no respeito; fortalecer as habilidades de escrita criativa e de atuação/desempenho.

\section{INSTRUC̣ÕES}

1 Apresente este tópico como sendo bastante sério. Explicar:

- Nesta actividade iremos discutir e analisar os vários tipos de violência que as pessoas por vezes usam no relacionamento íntimo.

- Terão cerca de 15 minutos para preparar uma breve peça dramática relacionada com uma relação íntima — casados, indivíduos do sexo masculino-feminino não casados, ou casal do mesmo sexo.

- As vossas mini-dramas devem ajudarnos a pensar sobre como garantir que os relacionamentos se baseiem no respeito.

2 Divida os alunos em quatro grupos (ou menos, dependendo do número total de alunos), com cinco ou seis membros em cada grupo.

Dizer a dois dos grupos: Preparem uma breve peça de teatro (de 3-5 minutos) que demonstre um relacionamento íntimo com violência. Esta violência pode ser física ou psicológica. Tentem ser realistas, utilizando exemplos de incidentes que tenham testemunhado, ou de que tenham ouvido falar na vossa comunidade.
Dizer aos outros dois grupos: Preparem uma breve peça de teatro (de menos de cinco minutos) que demonstre um relacionamento íntimo baseado no respeito mútuo. Mostrem como as duas pessoas enfrentam uma situação de conflito ou diferença de opinião sem recorrer à violência.

3 Circule pela sala enquanto os grupos preparam as suas sátiras; ofereça a ajuda de que possam necessitar.

4 Começando pelas peças de teatro que demonstram violência, peça a cada grupo que apresente o seu drama à turma. Depois de cada apresentação, pergunte se os que estiveram a assistir têm alguma pergunta. Em seguida, pergunte que características de uma pessoa ou de um relacionamento levam à violência.

5 Siga o mesmo procedimento em relação aos dramas que demonstrem respeito, mas pergunte que características de uma pessoa ou de um relacionamento o tornam saudável e não violento. 
6 Dinamize uma discussão com base nas seguintes perguntas:

- Quais são as diferentes formas de violência em relacionamentos íntimos? [Sondar: controlo coacção, gritos e ameaças, assim como violência física].

- Quais são as características de um relacionamento violento? [Escrever as respostas no quadro sob o título "Relacionamentos Violentos"].

- Porque muitas pessoas, especialmente jovens, se sentem impotentes para fazer alguma coisa contra a violência doméstica? Elas são realmente impotentes?

- Que características tornam um relacionamento saudável? O que é necessário para conseguir uma relação baseada no respeito? [Escrever as respostas sob o título "Relacionamentos de Respeito"].

- Os exemplos usados nas peças de teatro são realistas? Testemunham estas situações no vosso dia-a-dia? Os exemplos de relacionamentos saudáveis apresentados nas histórias são realistas? Testemunham estas situações no vosso dia-a-dia?

- A violência física é usada essencialmente por homens contra as mulheres, ou as mulheres são igualmente violentas contra os homens? Quais acham que são as causas da violência numa relação? Quando testemunham este tipo de violência, o que fazem normalmente? O que poderiam fazer?

- Acham que é possível formar um relacionamento íntimo com base no respeito? O que podemos fazer individualmente para construir relacionamentos íntimos saudáveis? 


\section{medidas contra a violência baseada no género}

\section{DURACÃO:}

Etapas 1-4: 1 hora

Etapas 5-7: 1 hora

\section{MATERIAL:}

Quadro + giz

\section{PREPARAC̣ÃO:}

Os estudantes devem possuir um conhecimento prévio sobre a questão da violência contra as mulheres.
VISÃO GERAL: Em pequenos grupos, os estudantes desenvolvem estratégias para eliminar a violência contra as mulheres e apresentam as suas estratégias sob a forma de noticiários de TV ou de apresentação formal para o governo.

OBJECTIVOS: Permitir que os estudantes apresentem pelo menos duas ideias de medidas contra a violência de género; fortalecer as habilidades de resolução de problemas e de falar em público.

\section{INSTRUÇÕES}

1 Divida os estudantes em grupos de quatro ou cinco. Explicar que metade dos grupos deve preparar um noticiário para a televisão e a outra metade deve preparar uma apresentação para o governo.

2 Pergunte: “Quem é responsável por pôr termo à violência contra as mulheres e as raparigas?"

3 Explique:

- Imaginem algumas estratégias ou programas destinados a reduzir a violência contra as mulheres.

- Têm 40 minutos para preparar uma apresentação de cinco a dez minutos (um noticiário para a televisão ou uma apresentação para o governo local ou nacional, dependendo do grupo em que se encontram).

- A vossa apresentação deve partir do pressuposto de que a vossa audiência já conhece o problema da violência. A vossa tarefa é mostrar que medidas positivas estão a ser tomadas para responder ao problema.
- Tentem incluir o que foi feito (ou pode ser feito) por jovens e por adultos na vida quotidiana; pelas organizações locais e pelas comunidades; pelo governo ou pelas agências das Nações Unidas.

- Devem também considerar como envolver os

Para as apresentações ao governo local/nacional, explicar: Devem informar os funcionários do governo sobre as medidas que foram tomadas por grupos e pessoas singulares. Esclarecer como o governo deve responder. Alguns alunos podem desempenhar o papel de funcionários do governo e outros podem agir como peritos ou cidadãos interessados na questão.

Para a apresentação dos noticiários de televisão, explicar: Lembrem-se que devem centrar a atenção das pessoas e ser o mais breve e conciso possível. Usem histórias de interesse humano para demonstrar o trabalho que está a ser realizado com vista a resolver o problema da violência em relacionamentos pessoais. Mantenham a vossa apresentação pessoal e envolvente. homens e os rapazes neste esforço. 
4 Certifique-se de que todos entendem a tarefa. Diga aos grupos que têm 45 minutos para a preparação. Circule pelos grupos enquanto trabalham.

5 Antes do início das apresentações, dê aos grupos cinco minutos para reverem as suas apresentações e aperfeiçoarem o seu plano.

6 Peça a todos os grupos que façam as suas apresentações. Tome notas das ideias contidas nos seus programas.

7 Depois de todas as apresentações terem sido ouvidas, pergunte:

- Foi difícil pensar em formas de reduzir a violência contra as mulheres?

- Quais são alguns dos temas ou ideias comuns que diferentes grupos tinham para trabalhar com as mulheres?

- E para trabalhar com os homens e os rapazes?

- Que ideias acham que são melhores e porquê?

- Todos têm a responsabilidade de trabalhar para pôr termo à violência contra as mulheres?

- Vocês, como jovens, ha algo que possam fazer agora para pôr termo à violência contra as mulheres e as raparigas nas famílias, escolas e comunidade? 


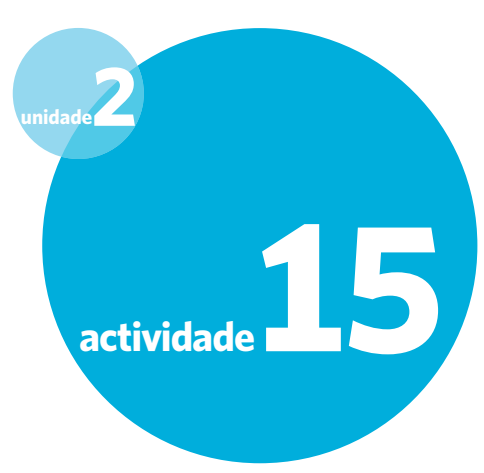

DURAC̄ÃO:

Etapas 1-3: 15 minutos

Trabalho de Casa: 1 hora

Paso 4: 30 minutos

\section{MATERIAL:}

Quadro + giz (para a etapa 3);

Ficha do mapa de entrevistas.

\section{PREPARAC̄ÃO:}

Se alguns alunos não tiverem uma pessoa mais velha para entrevistar, identificar pessoas mais velhas que estejam dispostas a serem entrevistadas. Se possível, fazer cópias do mapa para cada aluno.
Adaptado de Gendering Prevention Practices: A Practical Guide to Working with Gender in Sexual Safety and HIV/AIDS Awareness Education. (Jill Lewis. 2003. Oslo: NIKK-The Nordic Institute for Women's Studies and Gender Research.) $<w w w . n i k k$ uio.no>.

\section{imagens de papéis e normas de género em mudança}

VISÃO GERAL: Os alunos entrevistam um avô (ou alguém dessa geração) sobre os papéis e normas de género quando eram jovens, comparam-nos com as suas próprias experiências e discutem como os papéis de género mudam.

OBJECTIVOS: Facilitar que os alunos indiquem pelo menos três formas como os papéis ou normas de género mudaram ao longo do tempo; fortalecer as habilidades de pesquisa.

\section{INSTRUC̣ÕES}

1 Explique que esta actividade explora como as normas de género mudaram ao longo do tempo.

- Vão entrevistar separadamente duas pessoas da geração dos avós (vossos avós ou outra pessoa). Se possível, devem ser do mesmo sexo que o vosso. Se não conhecerem outras pessoas mais velhas, a vossa família (ou eu) pode ajudar-vos a identificar uma pessoa mais velha para entrevistarem.

- Perguntem a cada pessoa mais velha como eram os papéis masculinos e femininos durante a sua juventude e adolescência. Procurem saber o que acham que mudou desde então. Perguntem sobre a educação, passatempo, amizades, romance, costumes relacionados com o casamento e trabalho. Deixem que a pessoa diga tudo o que quiser descrever.

2 Desenhe o mapa de entrevistas no quadro, ou se tiver tirado cópias do mapa, distribua-as. Fazer a revisão do mapa e de como usá-lo, explicando:

- Na coluna esquerda, registem as respostas que a pessoa der às vossas perguntas.

- Depois da entrevista, escrevam na coluna direita como estes papéis são hoje em dia.
3 Certifique-se de que todos entendem a tarefa e que têm alguém para entrevistar. Diga aos alunos quando as suas entrevistas e mapas devem ser concluídos.

4 Depois de os alunos concluírem as suas entrevistas, discutir:

- A quem entrevistaram?

- Como se sentiram ao entrevistar pessoas mais velhas sobre os papéis de género? Houve algo que fuera incomodo ou difícil de abordar para vocês o para as pessoas entrevistadas?

- O que disseram que vos surpreendeu? Com base neste exercício, acham que os papéis de género são inalteráveis ou que mudaram?

- Em que áreas da vida os papéis e normas de género mais mudaram? Que mudanças acham que são para o melhor? E para o pior? Porquê?

- Muitos factores desencadeiam a mudança. De que forma os órgãos globalizados de mídia podem afectar os papéis de género? E a tecnologia e a Internet? As acções de líderes individuais? As acções dos movimentos de base em prol da justiça social?

- Acham que os papéis de género continuarão a mudar na próxima geração? De que maneira? 


\section{MAPA DE ENTREVISTAS}

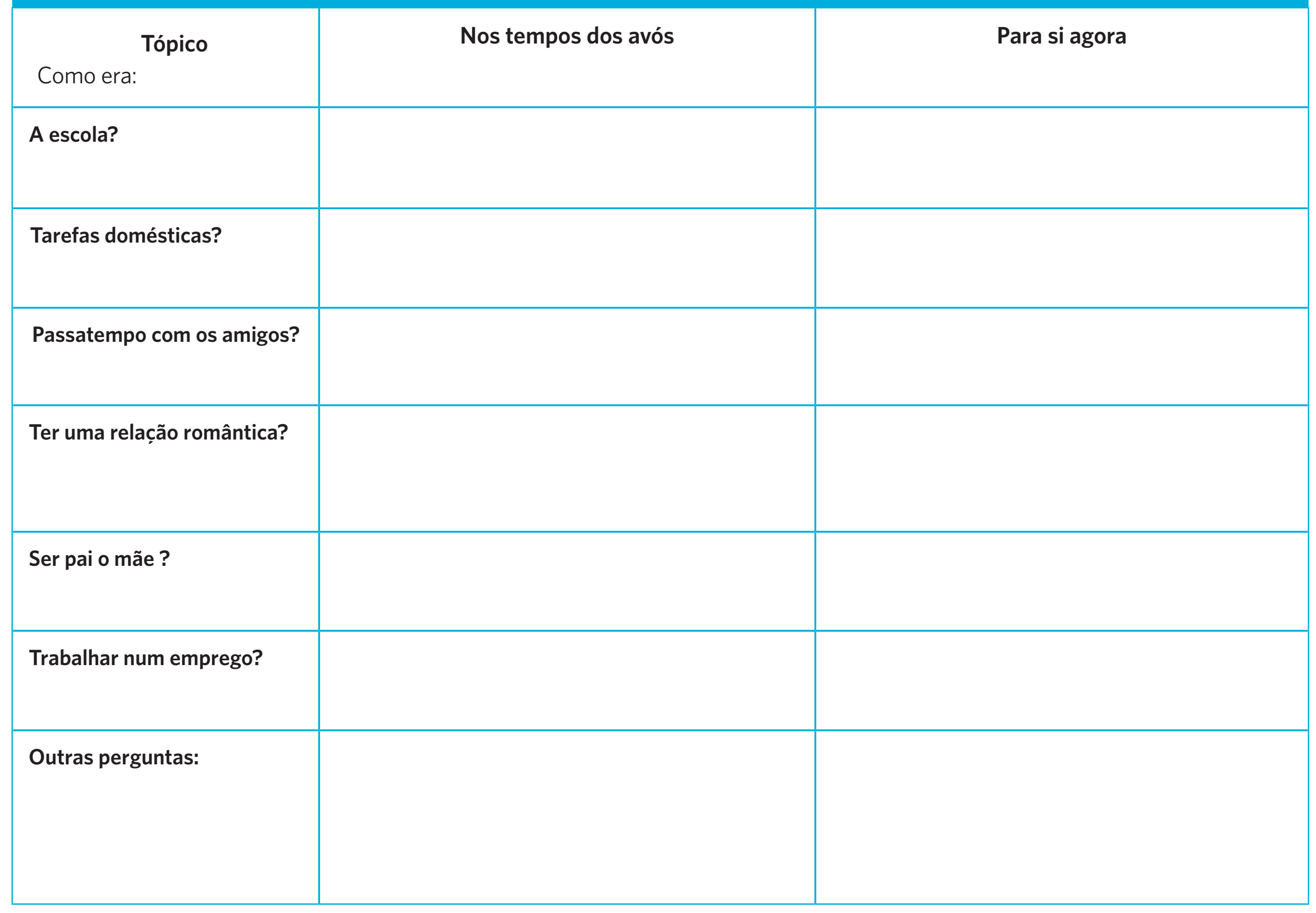




\section{dizer a verdade ao poder}

\section{DURAĈ̣̃O:}

Etapas 1-7: 45 minutos

\section{Etapa 8: 45 minutos}

\section{MATERIAL:}

Poder-se-á mostrar aos alunos alguns exemplos de canções, letras de rap, ou poemas.

\section{PREPARAC̄ÃO:}

Familiarizar-se com a música popular dos alunos. Para a Etapa 4, considerar se deve acrescentar quaisquer cenários que sejam adequados ao seu contexto. Incentivar os alunos a pensarem nos seus próprios cenários e descrevê-los. Decidir se deve indicar alguns alunos para juízes (ver a etapa 6)
VISÃO GERAL: Ao escreverem canções e poemas, os alunos praticam como falar a favor da igualdade de género nos relacionamentos. Antes de iniciar esta actividade, cada grupo deve ter realizado e concluído pelo menos uma das seguintes actividades deste livro: 1, 3, 5 ou 6.

OBJECTIVOS: Ajudar os alunos a analisar e identificar poder desigual em relacionamentos masculinos-femininos.

\section{INSTRUC̣ÕES}

1 Explique que esta actividade deve explorar como os papéis de género por vezes levam a diferenças de poder nos nossos relacionamentos. Perguntar:

- Quais são algumas das coisas que aprendemos sobre os papéis e igualdade de género?

- Como podem os papéis de género afectar se as pessoas têm, ou não, poder igual nos seus relacionamentos interpessoais? [Dar cinco a dez minutos para as respostas.]

2 Explique aos alunos que devem explorar este tópico escrevendo poemas ou canções. Podem utilizar os estilos hip-hop, palavra falada, rap ou outros estilos.

3 Pedir aos alunos que formem pares (de um único sexo ou rapaz-rapariga) e discutam com o seu parceiro como pretendem dividir o trabalho, por exemplo, para escrever e representar a sua peça em conjunto ou decidir que uma pessoa assuma a tarefa de orientar a parte de escrever e a outra de representar.
4 Sugira exemplos de cenários que os alunos possam utilizar como base para a sua canção ou poema.

- Um rapaz a defender o seu amigo gay

- Um homem a dizer ao amigo que não tem o direito de forçar a sua esposa a ter relações sexuais

- Um banqueiro a explicar a um marido renitente por que motivo está a conceder um empréstimo à sua esposa (ou uma mulher a dizer por que necessita e merece ter o seu próprio dinheiro)

- Uma rapariga adolescente que enfrenta o assédio sexual de homens mais velhos

- Um homem que insiste que a sua esposa deve fazer todo o trabalho de casa, cozinhar e cuidar das crianças, embora os dois trabalhem em tempo inteiro

- Uma rapariga que enfrenta estigma quando regressa à sua comunidade depois de ter sido vendida para fazer trabalho sexual

- Uma esposa jovem que está a ser punida pelo marido porque o seu dote é pequeno

- Um rapaz que está a ser ridicularizado por outros rapazes porque o seu comportamento não é de macho 
- Uma esposa ou namorada que tenta convencer o marido / namorado a usar o preservativo quando ele não quer

- Um rapaz que defende a sua mãe quando o pai se torna violento com ela

- Um tipo de ideia diferente: a declaração do antigo Secretário-Geral das Nações Unidas, Kofi Annan: "Sabemos o que é preciso para virar a maré contra esta epidemia (SIDA)... É necessária uma mudança real e positiva que dará maior poder e confiança às mulheres e às raparigas e transformará as relações entre mulheres e homens a todos os níveis da sociedade."

- Uma outra ideia que tenham de vós próprios, mas que requer a aprovação do professor.

5 Dar aos alunos instruções sobre como realizar a tarefa:

- Passem alguns minutos com o vosso parceiro para decidir sobre que cenário pretendem escrever.

- Passem o resto da aula a escrever a vossa canção ou poema.

- Pensem nos argumentos que as várias pessoas destes cenários poderão apresentar e o que poderão dizer para provar o que quiserem provar.

- Pensem também em como se sentiriam se fossem uma pessoa da história e como essa pessoa havia de querer manifestar os seus sentimentos através de palavras.

- Lembrem-se que isto não é uma piada e que este não é o momento de menosprezar a violência.
6 Explique quando devem apresentar os resultados do seu trabalho. Se decidir ter um painel de juízes, peça a três ou quatro estudantes para seleccionarem as suas três apresentações favoritas. Poderá escolher os alunos que se sintam pouco à vontade para cantar ou desempenhar.

7 Dê aos alunos 25-30 minutos para escreverem a sua canção ou poema. Se for necessário, dê-lhes tempo para concluírem este projecto como trabalho de casa.

8 Quando as apresentações começam (esta pode ser uma sessão diferente), reúna alunos-juízes e esclareça os critérios a serem aplicados na selecção dos vencedores (por exemplo, melhor mensagem, melhor apresentação, melhor canção, melhor poema). Peça aos alunos para fazerem a sua apresentação.

Trabalho de Casa: Escolher duas das perguntas a seguir e escrever um parágrafo completo sobre cada uma delas no vosso diário ou caderno.

- Quem normalmente tem mais poder num relacionamento íntimo homem-mulher?

- Quais são os custos dos desequilíbrios de poder nos relacionamentos?

- O poder desigual pode também existir em relacionamentos entre pessoas do mesmo sexo?

- Quais são algumas formas que as pessoas podem tentar para obter uma maior igualdade nesses relacionamentos íntimos? 


\section{debate sobre a educação sexual}

\section{DURAC̣ÃO:}

45 minutos

\section{MATERIAL:}

Quadro + giz

\section{PREPARAC̣̃̃O:}

Reflectir sobre a forma como o debate irá decorrer. Rever com atenção a Informação para os

Professores na página a seguir. Se for possível, convidar um outro professor para assistir ao debate e representar o papel de juiz (determinar que lado vence o debate). Se mais nenhum professor estiver disponível, seleccionar dois estudantes para serem juízes consigo. Considerar a possibilidade de atribuir um prémio à equipa vencedora.
VISÃO GERAL: Os alunos debatem se os jovens devem aprender sobre a sexualidade, género e saúde sexual - ou se devem aprender apenas a abster-se de relações sexuais até ao casamento.

OBJECTIVOS: Permitir que os alunos descrevam perspectivas de políticas sobre a educação sexual e considerem os seus próprios pontos de vista; fortalecer as suas habilidades analíticas e de falar em público.

\section{INSTRUC̣ÕES}

1 Apresente a actividade nos seguintes moldes:

- Temos a tendência de pensar na sexualidade como uma questão muito pessoal e particular. Porém, na realidade, muitos aspectos da sexualidade tornaram-se questões de políticas públicas. Por exemplo, muitos legisladores, políticos e cidadãos comuns defendem as suas opiniões sobre a educação sexual e HIV.

- Hoje vamos realizar o nosso próprio debate sobre a educação sexual e HIV. Vamos realizar um debate formal, o que significa que devemos preparar e apresentar argumentos sobre os dois lados da questão.

2 Divida o grupo em duas equipas. Se não tiverem um juiz de fora, peça a dois voluntários para o ajudarem a avaliar o debate, e não participarem numa equipa.

3 Apresente o tópico do debate: "Educação sexual: As escolas devem ensinar os jovens que estes devem abster-se de relações sexuais até ao casamento; não devem ensinar sobre preservativos, contracepção ou relações de género."
4 Explique os procedimentos do debate:

- Uma equipa prepara argumentos a favor desta afirmação e a outra prepara argumentos contra. esta posição. Pensem em todas as razões com que alguém pode concordar com este lado. Pensem em factos e argumentos para apoiar o outro lado. Abordem todos os aspectos da afirmação.

- Seleccionem dois oradores da vossa equipa para apresentarem argumentos para a equipa. [Grupos de sexo misto devem seleccionar 1 rapaz, 1 rapariga.]

- Os que foram escolhidos como primeiros oradores: Cada um de vocês deve apresentar um argumento básico de 3 minutos. Os vossos colegas de equipa devem ajudar a desenvolver o vosso argumento. Segundos apresentadores: Devem responder à apresentação básica do lado oposto, pelo que escutem com atenção e tomem notas para poderem preparar uma resposta de três minutos.

- Em seguida, teremos ums minutos de perguntas e respostas entre os que não apresentaram: Os membros da equipa podem apresentar os seus comentários ou colocar uma pergunta à equipa Devem representar o papel de alguém que assume 
adversária. Qualquer pessoa da equipa adversária que não tenha apresentado pode responder.

- Cada equipa terá 10 minutos para discutir as questões e preparar um argumento para o debate. Após o debate, um lado será considerado vencedor. A equipa vencedora será seleccionada não com base no lado com que o(s) juiz(es) concorda $(\mathrm{m})$, mas no lado que apresentou um melhor trabalho de fazer argumentos eficazes.

5 Anuncie a equipa que apoiará a afirmação e a equipa que se deve opor à afirmação. Dê às equipas dez minutos para prepararem as suas observações; circule para ajudá-las e garantir que toda a esquipa esteja envolvida. Se tiver alunos-juízes, também aproveite este tempo para pedir-lhes para cronometrar as apresentações e informar os apresentadores quando o tempo tiver expirado. Dar orientação aos alunos-juízes sobre como devem avaliar os debates (por exemplo, devem procurar analisar factos sólidos dos participantes no debate).

6 O primeiro apresentador de cada equipa deve expor um argumento introdutório ( 3 minutos cada; 6 minutos no total). Em seguida, o segundo apresentador de cada equipa deve responder ao argumento da equipa adversária (3 minutos cada; 6 minutos no total). Por último, cada dos outros membros da equipa faz perguntas e comentários (6 minutos). Informar ao grupo quando chegar a altura de um último comentário breve de cada lado.

7 Conferencie com o(s) juiz(es) e decida que equipa venceu o debate. Em conjunto com os alunosjuízes, apresente feedback positivo concreto a cada grupo sobre o que fez bem.
8 Depois de anunciar o vencedor, discuta os seguintes aspectos:

- Quantos de vocês foram integrados num lado com que concordavam? [braços erguidos] Com que não concordavam? [braços erguidos] Foi fácil ou difícil argumentar a favor de algo contra as vossas convicções?

- A educação sexual é o único aspecto da sexualidade que se tornou numa questão de políticas públicas? Ou a sociedade exerce algum controlo sobre muitos aspectos da sexualidade? Quais são algumas questões relacionadas com a sexualidade sobre as quais existem leis, costumes e normas sociais que influenciam o que as pessoas pensam ou se sentem livres para fazer? [Sondar o seguinte: sexo forçado; diferentes padrões de comportamento sexual permissiveis para rapazes e raparigas (o "padrão duplo"); as mulheres que têm que ocultar sempre o seu corpo em público (em alguns contextos); pressão para os rapazes se tornarem sexualmente activos; estigmatização (ou criminalização) da homossexualidade.]

- Todos concordam com as atitudes culturais dominantes sobre a sexualidade? Algumas pessoas optam por viver de acordo com uma atitude ou crença diferente? As atitudes relacionadas com a sexualidade são as mesmas em todo o lado ou variam? As atitudes mantêmse as mesmas para sempre, ou mudam? Então, a sexualidade é apenas uma questão particular? Ou é também uma questão que deve preocupar a sociedade em geral?
INFORMAC̣ÃO PARA OS

\section{PROFESSORES}

As escolas devem ensinar os jovens que estes devem abster-se de relações sexuais até ao casamento; não devem ensinar sobre preservativos, contracepção ou relações de género.

SIM ou NÃO?

Em muitos países, está a decorrer um debate sobre a educação sexual. Os que acreditam que os jovens devem receber informação apenas sobre a abstinência de relações sexuais muitas vezes pensam que ensinar os jovens sobre o sexo seguro os incentiva a praticar a actividade sexual mais cedo do que se não tivessem recebido essa informação. No entanto, pesquisas efectuadas revelam que uma educação sexual abrangente não conduz à antecipação da idade do primeiro acto sexual. Os que acreditam na educação sexual abrangente (incluindo a informação sobre sexo seguro) defendem que proporciona aos jovens as ferramentas que Ihes permitem tomar decisões salutares e seguras sobre a sua vida sexual. 


\section{primeiras impressões}

\section{DURAC̣ÃO:}

40 minutos

\section{MATERIAL:}

Quadro + giz; cópias de "A História de Maya" para metade dos alunos e cópias de "A

História de Rasul" para a outra metade; espaço físico adequado para que os dois grupos possam conversar sem ouvir o que o outro grupo diz.

\section{PREPARAC̄̃O:}

Estar preparado para explicar o que é um adjectivo. Considerar como garantir que a discussão seja respeitosa. Estar preparado para desafiar a utilização de gírias locais que sejam desrespeitosas, em particular para as raparigas sexualmente activas. Rever a informação sobre o duplo padrão do comportamento sexual na Unidade 3 do livro de DIRECTRIZES (acessível em $<$ www.itsallone.org>) ou no seu próprio programa.
VISÃO GERAL: Os alunos analisam a sua resposta a um personagem de uma história com base na sua suposição de que o personagem é do sexo masculino ou feminino.

OBJECTIVOS: Aumentar o conhecimento dos estudantes sobre as suposições e percepções sobre uma pessoa com base no seu sexo; fortalecer as habilidades de pensamento crítico.

\section{INSTRUC̣ÕES}

1 Explique:

- Hoje vamos ler e discutir uma história sobre as experiências, sentimentos e desafios com que os adolescentes se confrontam.

- Vamos formar dois grupos; os membros de cada grupo devem ler uma história, discutir as suas opiniões e escrever as suas respostas no papel.

2 Divida a classe ao meio. Distribua "A História de Maya" a um grupo e "A História de Rasul" ao outro grupo. (Não explicar nada sobre as histórias). Dê aos grupos tempo para ler, responder às perguntas e comparar as respostas dentro de cada grupo. Certifique-se de que os dois grupos estão suficientemente afastados um do outro para não ouvirem o que cada um diz.

3 Passados 15 minutos, peça ao grupo que leu a história de Rasul que apresente, de forma resumida, as suas respostas a cada uma das perguntas que se encontram no fim da história sem explicar, nem discutir o seu raciocínio. Escreva algumas das respostas principais (adjectivos, substantivos) no quadro.
4 Proceda da mesma forma com o grupo que leu a história de Maya.

5 No topo da lista de palavras criadas pelo grupo que leu a história de Rasul, escreva "Rasul." No topo da lista de palavras criadas pelo grupo que leu a história de Maya, escreva "Maya."

6 Revele que as duas histórias são idênticas, à excepção do sexo da pessoa. Em seguida, pergunte:

- O que notamos em relação às respostas relativas à história de Maya comparativamente à de Rasul?

- O que isto nos diz acerca dos padrões para as raparigas em comparação com os padrões para os rapazes?

- Este duplo padrão afecta as raparigas da nossa comunidade?

- O que acham deste duplo padrão? 


\section{A História de MAYA}

Maya teve a sua primeira relação sexual aos 16 anos. As duas amigas dela gracejavam com ela por nunca ter tido um namorado e incentivaram-na a convidar um certo rapaz para sair e ter relações sexuais com ele. Ela estava curiosa, mas principalmente sentiu-se pressionada pelas amigas e, por essa razão, convidou o rapaz e tiveram relações sexuais. Quase todos na escola ficaram a saber que Maya e o rapaz tinham tido relações sexuais.

Nos dois anos seguintes, Maya teve relações sexuais com outros quatro rapazes. Um era colega de escola, um era vizinho, um era alguém que conheceu no local de trabalho e um que conheceu através de uma amiga. Ela gostava de ter relações sexuais. Maya sabia que não queria casar com nenhum deles, mas foi simpática para cada um deles e nunca mentiu sobre os seus sentimentos. Ter parceiros sexuais é algo que fazia Maya sentir-se atraente e importante.

A maioria das vezes, Maya tinha cuidado em relação ao uso do preservativo, mas uma vez engravidou e fez o aborto. Uma outra vez contraiu uma infecção transmitida sexualmente de um parceiro, mas foi tratada imediatamente.

Agora Maya está comprometida com um jovem com quem a família quer que ela se case. Ela gosta deste jovem, mas sabe que se deve abster do acto sexual com ele até se casarem daqui a dois anos. Quando visitava um primo numa outra cidade, encontrou-se com um dos antigos namorados que quis voltar a ter relações sexuais com ela e Maya decidiu aceitar só desta vez antes do casamento. Achava que “Afinal, dois anos sem sexo é muito tempo.” Depois disso, confidenciou com a sua melhor amiga, que se mostrou compreensiva.

Após a leitura da história, pensem nas seguintes perguntas e discutam-nas no vosso grupo:

1 O que acham que os colegas de Maya pensam dela? Que "rótulo" poderão usar para descrever Maya?

2 Qual a vossa opinião sobre Maya?

3 Elaborem uma lista de pelo menos três ou quatro adjectivos que acham que descrevem Maya. Por exemplo, ela é feliz ou infeliz? Autoconfiante ou insegura? Honesta ou desonesta? Realista ou irrealista? Atraente ou não atraente? Respeitável ou não respeitável? Típica para uma rapariga ou atípica? Moral ou imoral? 


\section{A História de RASUL}

Rasul teve a primeira relação sexual aos 16 anos. Os seus dois amigos gracejavam com ele por nunca ter tido uma namorada e incentivaram-no a convidar uma certa rapariga para sair e ter relações sexuais com ela. Ele estava curioso, mas principalmente sentiu-se pressionado pelos amigos e, por essa razão, convidou a rapariga e tiveram relações sexuais. Quase todos na escola ficaram a saber que Rasul e a rapariga tinham tido relações sexuais.

Nos dois anos seguintes, Rasul teve relações sexuais com outras quatro raparigas. Uma era colega de escola, uma era vizinha, uma era alguém que conheceu no local de trabalho e uma que conheceu através de um amigo. Ele gostava de praticar relações sexuais. Rasul sabia que não queria casar com nenhuma delas, mas foi simpático para cada uma delas e nunca mentiu sobre os seus sentimentos. Ter paceiros sexuais é algo que fazia Rasul sentir-se atraente e importante.

A maioria das vezes, Rasul tinha cuidado em relação ao uso do preservativo, mas engravidou uma rapariga, que fez o aborto. Uma outra vez contraiu uma infecção transmitida sexualmente de uma parceira, mas foi tratada imediatamente

Agora Rasul está comprometido com uma mulher jovem com quem a família quer que ele se case. Ele gosta desta jovem, mas sabe que se deve abster do acto sexual com ela até se casarem daqui a dois anos. Quando visitava um primo numa outra cidade, encontrou-se com uma das antigas namoradas que quis voltar a ter relações sexuais com ele e Rasul decidiu aceitar só desta vez antes do casamento. Achava que "Afinal, dois anos sem sexo é muito tempo." Depois disso, confidenciou com o seu melhor amigo, que se mostrou compreensivo.

\section{Após a leitura da história, pensem nas seguintes perguntas e discutam-nas no vosso grupo:}

\section{O que acham que os colegas de Rasul pensam dele? Que "rótulo" poderão usar para descrever Rasul?}

\section{Qual a vossa opinião sobre Rasul?}

3 Elaborem uma lista de pelo menos três ou quatro adjectivos que acham que descrevem Rasul. Por exemplo, ele é feliz ou infeliz? Autoconfiante ou inseguro? Honesto ou desonesto? Realista ou irrealista? Atraente ou não atraente? Respeitável ou não respeitável? Típico para um rapaz ou atípico? Moral ou imoral? 


\section{a verdade sobre o desejo}

VISÃO GERAL: Os alunos concluem um exercício verdadeiro/falso sobre o desejo sexual e género.

OBJECTIVOS: Permitir que os alunos identifiquem informação correcta sobre o desejo sexual.

\section{INSTRUÇÕES}

1 Diga aos alunos:

- Hoje vamos discutir o tópico de desejo sexual. Vamos dissipar alguns mitos comuns sobre este assunto.

- Primeiro, vamos realizar um exercício verdadeiro/falso.

2 Distribua o mapa e diga aos alunos para o preencherem rapidamente.

3 Peça a um voluntário para ler a primeira afirmação e em seguida incentive a discussão perguntando:

- Quantos de vós acham que a afirmação é verdadeira?

- Quem acha que é falsa?

Se ninguém der a resposta certa, faça perguntas para ajudar o grupo a chegar à resposta certa. Apresente a resposta certa apenas se ninguém no grupo chegar a ela. Procure saber se alguém ainda tem uma pergunta ou comentário a fazer.
4 Repita este processo para cada afirmação.

5 Use os últimos dez minutos para perguntar:

- Quais são algumas das coisas que acharam que eram verdadeiras no início da sessão e que acabaram sendo mitos?

- Que efeito pode este tipo de desinformação ter nos vossos sentimentos sobre vós próprios e a vossa sexualidade?

- O que notam em relação às mensagens da sociedade sobre o desejo masculino em comparação com as suas mensagens sobre o desejo feminino?

- Que efeito acham que estes mitos bastante enraizados podem ter no relacionamento sexual?

- Porque acham que recebemos diferentes mensagens sobre o desejo masculino e feminino? Deve ser assim?

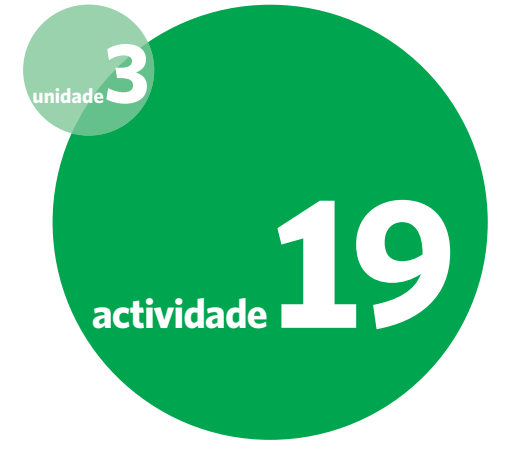

DURAC̣ÃO:

45 minutos

\section{MATERIAL:}

Quadro + giz; número de cópias suficientes do "Mapa sobre o Desejo Sexual" para cada aluno ou escrever as perguntas verdadeiro/ falso no quadro; chave de respostas.

\section{PREPARAC̣̃̃O:}

Rever e adaptar o mapa consoante as necessidades. Procurar ter a informação necessária para esclarecer as respostas. 


\section{FICHA TÉCNICA SOBRE O DESEJO SEXUAL - QUAL É A VERDADE?}

\section{Ler cada afirmação. Decidir se é verdadeira (V) ou falsa (F). Assinalar a sua resposta no espaço à direita.}

V ou F?

\begin{tabular}{|c|c|}
\hline 1 & A maioria das mulheres realmente não deseja o sexo. \\
\hline 2 & Se deseja ter relações sexuais, tem que tê-las. \\
\hline 3 & A expectativa social de que as mulheres não devem querer ter relações sexuais pode afectar o seu nível de desejo. \\
\hline 4 & $\begin{array}{l}\text { Se um rapaz tiver uma erecção, significa que quer ter relações sexuais; se a vagina de uma rapariga lubrificar, significa que } \\
\text { quer ter relações sexuais. }\end{array}$ \\
\hline 5 & Algumas mulheres querem ter relações sexuais mais do que os seus parceiros sexuais. \\
\hline 6 & As pessoas têm fantasias sexuais sobre coisas que não desejam viver na vida real. \\
\hline 7 & O receio de engravidar ou de contrair uma ITS pode afectar o desejo sexual. \\
\hline 8 & O nível de desejo sexual de todos muda com o tempo e com circunstâncias diferentes. \\
\hline 9 & Se você for do sexo masculino, então quer ter sempre relações sexuais. \\
\hline 10 & A maioria das pessoas mais velhas ainda sente desejo sexual. \\
\hline 11 & Se um homem não tiver uma erecção numa situação sexual, não deseja a pessoa com quem está. \\
\hline 12 & Alguns medicamentos afectam o desejo sexual. \\
\hline 13 & Uma pessoa pode sentir desejo sexual por alguém que não ama. \\
\hline 14 & É normal que os homens por vezes não queiram ter relações sexuais. \\
\hline 15 & Se tiver desejo sexual, ficará sexualmente excitado. \\
\hline
\end{tabular}




\section{respostas ao "mapa sobre o desejo sexual: qual é a verdade?"}

1 Falso A maioria das mulheres deseja ter relações sexuais. Contudo, se uma mulher não tiver prazer, pode perder o interesse.

2 Falso O desejo sexual não tem que necessariamente levar à actividade sexual. Na verdade, as pessoas podem gostar de se sentir "excitadas" sem pretenderem ter relações sexuais.

3 Verdadeiro O desejo sexual é afectado pelas expectativas sociais. Se uma mulher acha que não devia querer ter relações sexuais, ela poderá suprimir ou negar o seu desejo.

4 Falso As erecções e a lubrificação podem ocorrer sem nenhum motivo aparente, ou por razões não relacionadas com o desejo. Por exemplo, a maioria dos homens acorda com uma erecção porque a sua bexiga está cheia. Os rapazes adolescentes muitas vezes têm erecções espontâneas que não estão relacionadas com o desejo sexual, nem com a excitação.

5 Verdadeiro Os níveis de desejo sexual variam de pessoa para pessoa e com as circunstâncias. Em alguns casais, em algum momento da sua vida, uma mulher pode desejar ter mais relações sexuais do que o seu parceiro.

6 Verdadeiro As fantasias usualmente são apenas fantasias. Uma pessoa pode não querer viver a fantasia.

7 Verdadeiro Os estados emocionais como o medo podem afectar o desejo sexual de uma pessoa.

8 Verdadeiro Os níveis "normais" de desejo sexual variam imenso e mudam. O desejo sexual é afectado por factores de ordem física, emocional e social. Se o nível de desejo de uma pessoa estiver a causar-lhe problemas, essa pessoa pode conversar com um profissional de saúde sexual.

9 Falso Os homens nem sempre desejam ter relações sexuais. Eles registam variações dos níveis de desejo, assim como todas as pessoas.

10 Verdadeiro O desejo sexual pode diminuir com a idade. Se uma sociedade desaprova a sexualidade das pessoas mais velhas, o seu nível de desejo pode ser afectado pelo estigma. Muitas pessoas sentem algum desejo sexual ao longo das suas vidas.

11 Falso Um homem pode não ter uma erecção numa situação sexual por muitas razões, incluindo factores médicas (como diabetes ou doença cardíaca), uso de certos medicamentos e factores emocionais (como ansiedade sobre desempenho sexual, fúria em relação à outra pessoa ou a qualquer outra pessoa ou porque está preocupado.

12 Verdadeiro Uma diminuição do desejo sexual é um efeito secundário de certos medicamentos. Alguns medicamentos como o Viagra aumentam a função eréctil e são tomados especificamente para esse fim. Os médicos normalmente não discutem os efeitos secundários sexuais dos medicamentos com os seus pacientes. Se os efeitos secundários constituem motivo de preocupação, consultar um médico ou farmacêutico.

13 Verdadeiro As pessoas muitas vezes confundem desejo sexual com amor. A pessoa pode amar alguém e não desejar ter relações sexuais com ela e pode desejar ter relações com alguém que não ama.

14 Verdadeiro Ninguém, seja do sexo masculino ou feminino, quer ter sempre relações sexuais.

15 Falso Algumas pessoas desejam ter relações sexuais, mas não ficam sexualmente excitadas. Esta situação acontece com a maior parte das pessoas em algum momento. É algo sobre que não se devem preocupar. 


\section{sentir-se diferente}

\section{DURAC̣̃̃O:}

35-40 minutos

\section{MATERIAL:}

Quadro + giz

\section{PREPARAĈ̣̃O:}

Ler toda a actividade; pensar em como discutir o tópico referente às minorais na sociedade com sensibilidade e respeito.

VISÃO GERAL: Os alunos identificam qual a sensação de se ser semelhante ou diferente das outras pessoas e reafirmam os direitos humanos dos grupos minoritários, incluindo as minorias sexuais.

OBJECTIVOS: Permitir que os alunos identifiquem emoções que associam com o facto de se ser diferente dos outros; reafirmar os direitos humanos de todas as pessoas, incluindo as minorias sexuais; fortalecer as habilidades de reflexão afectiva e de diálogo.

\section{INSTRUC̣ÕES}

1 Apresente o tópico obedecendo às seguintes etapas:

- Pensem em duas coisas importantes sobre vocês (que não seja a idade) que vos tornem muito semelhantes a muitos dos que estão aqui sentados convosco.

- Agora pensem em duas coisas que façam com que se sintam muito diferentes dos outros. Não vão partilhar estes aspectos. Podem escrever o que quer, mas algo que achem que é verdadeiro.

- Pensem sobre como as duas coisas que vos tornam semelhantes aos outros vos fazem sentir por dentro. Peguem nos vossos cadernos e escrevem quatro palavras de emoção que descrevam os sentimentos.

- Em seguida, voltem a pensar nas coisas que fazem com que se sintam diferentes. Qual é a emoção? Escrevam quatro palavras referentes a vossos sentimentos ou emoções.

2 Oriente uma discussão nas seguintes perguntas:

- Sem nomear o aspecto que vos faz sentiremse iguais ou diferentes, quais são alguns dos sentimentos que associam ao facto de serem semelhantes aos outros [Escrevam as respostas no quadro numa coluna.]

- Quais são as emoções que associam ao facto de serem diferentes? [Escrevam as respostas numa outra coluna.]
3 Lembre ao grupo que todos se sentem diferentes ou não se "enquadram" de alguma maneira e que é comum sentir isso. Dê os últimos 15 minutos para discutir as seguintes questões:

- Quando é que ser diferente dos outros é uma experiência positiva? Quais são os benefícios de ser único?

- Quando é que ser diferente é uma experiência negativa?

- Como é que as pessoas que são consideradas diferentes tendem a ser tratadas pelos outros? O que acha disso? [Sondar: Este tipo de tratamento é correcto?]

- Como quer ser tratado quando se sente diferente? As pessoas que são diferentes (e não fazem mal a ninguém) têm os mesmos direitos que os outros? Importa que sejam diferentes?

Trabalho de Casa: Pensar num grupo minoritário da sociedade. [Sondar o seguinte: pessoas portadoras de deficiência, pessoas de castas sociais inferiores, minorias étnicas ou raciais, minorias sexuais.] Como são tratadas na sua comunidade? Os seus direitos são por vezes violados? Alguém desse grupo já alguma vez se levantou para defender os direitos desse grupo? 


\section{sentir-se sexualmente atraído por alguém do mesmo sexo: histórias pessoais}

VISÃO GERAL: Os alunos lêem histórias de adolescentes que se apercebem que são homossexuais e discutem os sentimentos, as experiências e as reacções destes adolescentes. A desinformação deve ser corrigida.

OBJECTIVOS: Permitir que os alunos descrevam duas experiências comuns de jovens que são atraídos por outros do mesmo sexo, ter empatia com eles e corrigir a desinformação; fortalecer o pensamento crítico e as habilidades de parafrasear.

\section{INSTRUC̣ÕES}

1 Divida a turma em três grupos. Explique:

- Hoje vamos aprender sobre experiências sociais e sentimentos de jovens que são gays, ou seja, pessoas que são atraídas exclusiva ou primeiramente por outras do mesmo sexo. Vão ler estudos de caso reais sobre jovens gays.

- Cada grupo tem uma história diferente. Vão discutir e escrever a vossa resposta às três perguntas a seguir.

2 Escreva as seguintes perguntas no quadro e leia-as em voz alta:

Que sentimentos tem a pessoa de que a história fala? Enumerem o maior número de sentimentos que notarem.

Quais são algumas das coisas em que a pessoa da história acredita sobre as pessoas homossexuais? O que a pessoa da história faz sobre os seus sentimentos?

3 Distribua as fichas. Dê aos grupos dez minutos para ler, discutir e escrever respostas às perguntas. Digalhes que vão partilhar as suas respostas escritas com todo o grupo.
4 Passados dez minutos, peça a dois alunos do grupo de Nia que parafraseiem (não ler), de forma resumida, a história de Nia e que em seguida apresentem as suas respostas às três perguntas. Escreva os sentimentos de Nia no quadro. Repita este processo em relação às histórias de Lee e de Mo.

5 Reserve 15 minutos para discutir as seguintes perguntas com todo o grupo: têm em relação ao facto de serem gays? Quais foram as principais razões desses sentimentos? Como é que se aperceberam que eram gays ou lésbicas? Aconteceu algo com ele que os tenha "tornado gays?"

- O que sentiram ao ler estas histórias? O que vos surpreendeu? O que aprenderam sobre as pessoas que são gays?

- As atitudes e ideias sobre a diversidade sexual na sociedade estão a mudar?
- No geral, que tipos de sentimentos Nia, Lee e Mo

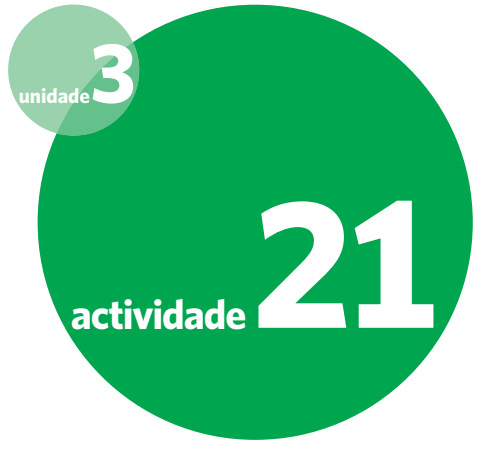

DURAC̣ÃO:

45-50 minutos

\section{MATERIAL:}

Quadro + giz; cópias de "Estudos de Caso sobre Crescer Gay."

\section{PREPARAÇÃO:}

Preparar-se meticulosamente para poder responder às perguntas sobre as histórias ou sobre o tema. Procurar garantir que os estudantes abordem este tópico como uma questão séria e que você se sinta à vontade para dar a aula. Se for necessário, procurar obter informação de uma organização com competência em diversidade sexual ou de uma outra fonte fiável. Se os termos aqui utilizados ("gay" e "lésbica") tiverem conotações negativas no seu contexto, usar outros termos que não tenham uma conotação negativa. 


\section{estudos de caso sobre crescer gay}

\section{FICHA DO GRUPO 1: A História de Nia:}

Sou uma lésbica de 25 anos de idade. Quando era criança, era boa aluna e tinha muitos amigos. Quando atingi a puberdade, comecei a sentir-me diferente. Tinha alguns sonhos em que beijava alguém. Não conseguia ver a cara da pessoa, mas conseguia sentirlhe o corpo, um corpo de mulher. Senti-me confusa e comecei a odiar-me. Aos 15 anos, de repente apercebime que me sentia realmente atraída por uma rapariga mais velha que conhecia. Parecia uma verdadeira paixão. Associando isto aos meus sonhos, apercebi-me lentamente e admiti para mim própria que me sentia atraída por mulheres. Mas a primeira vez que vi a palavra "homossexual" foi no artigo de uma revista sobre um polícia do sexo feminino que alegadamente violara uma rapariga de 17 anos. Lembro-me da maneira como a revista descrevia a homossexualidade como uma perversão e uma doença. Houve um outro artigo sobre homens gays e SIDA. Os dois artigos retratavam pessoas homossexuais como pervertidas e doentes. Constatei que seria banida, seria considerada uma "dessas pessoas." Todos querem ser amados e fazer parte da sociedade — ninguém quer ser banido. Pensei que houvesse algo de errado comigo, que eu estivesse doente. A palavra "lésbica" tornou-se uma enorme ameaça na minha mente. Era um tabu; eu era um tabu. Tive medo, considerei-me esquisita e anormal. Para poder enfrentar esta situação, refugieime nos meus estudos e fiquei conhecida por "traça".

\section{FICHA DO GRUPO 2: A História de Lee:}

Sou um homem gay de 23 anos de idade; cresci no campo. Quando tinha cerca de 11 anos, comecei a reparar que gostava de ver corpos de homens. Fiquei surpreendido e não sabia porquê. Havia um homem onde eu vivia que parecia e se comportava como uma mulher; a sua alcunha era "Rapariga." Eu tinha medo dele e sabia que não queria ser como ele. Lembro-me também de um momento em que um exemplar de uma revista sobre sexo chegou à nossa vila e continha alguma informação sobre gays, que eu li. Senti medo quando li o artigo. Depois mudámo-nos para a cidade, onde os meus amigos diziam que queriam ter relações sexuais com raparigas. Menti e disse-lhes que eu estava interessado numa rapariga especial, mas sempre a pensar em homens. Para encobrir esta situação, mostrei-me mais duro do que os outros rapazes e envolvi-me no desporto. Esperava que ninguém adivinhasse que eu era gay, e ninguém adivinhou. Mas odiava-me porque não conseguia entender por que razão eu era assim. Pensei "Porque não experimento?" Andei com cinco raparigas diferentes. Dava-lhes presentes, saíamos, às vezes íamos ao cinema. Continuei a tentar, mas não resultou. Cheguei a ter relações sexuais quatro vezes com uma rapariga, mas não me senti satisfeito. 


\section{estudos de caso sobre crescer gay}

\section{FICHA DO GRUPO 3: A História de Mo:}

Sou um homem gay de 22 anos. Quando era miúdo, tínhamos vizinhos que eram gays e os meus pais tinham outros amigos gays. Então cresci a saber que os gays eram pessoas como quaisquer outras - tal como os meus pais, tinham filhos, e emprego e animais de estimação. Quando tinha 15 anos, constatei que gostava do meu melhor amigo Benno mais do que apenas como amigo. Não sabia como lhe dizer, por isso fui visitar o amigo gay da minha mãe; ele vivia com o parceiro há 20 anos. Primeiro, ele disse que às vezes era preciso muita reflexão honesta para descobrirmos quem somos. Depois perguntou-me sobre as atitudes de Benno e incentivoume a ser honesto com ele. Explicou que Benno podia não sentir o mesmo em relação a mim e que, na verdade, Benno podia distanciar-se de mim. No dia seguinte, depois de praticar futebol, declarei os meus sentimentos a Benno. No início, ficou aborrecido e disse-me que achava que já não podíamos ser amigos. Fiquei arrasado. Alguns dias depois, Benno veio à minha casa. Disseme que não nutria sentimentos sexuais por mim, nem por qualquer pessoa do sexo masculino, mas queria continuar a ser meu amigo. Fiquei muito contente por ter o meu amigo de volta, embora não pudéssemos estar romanticamente envolvidos. Ser gay na adolescência nem sempre foi fácil e muitas vezes conheci pessoas que não se sentiam à vontade com o meu estilo de vida. Sei que tenho muita sorte de ter tanto apoio familiar; muitos jovens não têm. É por isso que agora trabalho numa linha directa para jovens que questionam a sua sexualidade e não têm a quem recorrer. 


\section{comportamento sexual - mitos e factos}

VISÃO GERAL: Os alunos jogam um jogo e decidem se as afirmações sobre o comportamento sexual são verdadeiras ou falsas. As ideias erradas são corrigidas durante a discussão.

OBJECTIVOS: Permitir que os alunos identifiquem informação correcta sobre o comportamento sexual.

\section{INSTRUC̣ÕES}

\section{DURAC̣̃O:}

Etapas 1-4: 45-50 minutos

Etapas 5-6 (caso se preveja uma sessão de perguntas e respostas): 10 minutos

\section{MATERIAL:}

Quadro + giz; uma cópia da ficha do aluno para cada equipa; pedaços de papel em branco e (se incluir a etapa 6); um saco ou envelope grande; chave de respostas.

\section{PREPARAC̣ÃO:}

Rever as afirmações contidas na ficha e certificar-se de que consegue explicar por que são verdadeiras ou falsas. Decidir se pretende incluir as etapas 5 e 6. Nesse caso, arranjar uma fonte de informação segura para responder às perguntas escritas.
1 Diga aos alunos que vão discutir mitos comuns sobre o comportamento sexual e distinguir mitos de factos.

2 Divida o grupo em duas equipas. No quadro, faça um mapa para registar a pontuação com uma coluna para cada equipa. Distribua as fichas e explique:

- Nas vossas equipas, discutam cada afirmação contida nesta folha e decidir se é verdadeira ou falsa. A vossa equipa tem sete minutos para preencher o mapa.

- No fim, iremos analisar todas as perguntas. Cada equipa deve dar a sua resposta. Registarei um ponto sempre que uma equipa der a resposta correcta. [Pedir que comecem o trabalho; dar 7 minutos.]

3 Peça a um voluntário que leia a afirmação em voz alta para ser analisada. Em seguida, pergunte a cada equipa se indicou Verdadeiro ou Falso. Esclareça qual é a resposta certa, registe um ponto na coluna da(s) equipa(s) que tiver(em) respondido correctamente e esclareça qualquer confusão ou perguntas. Repita este procedimento para cada afirmação. Dê um minuto a cada uma das equipas.

4 Depois de 20 minutos (no fim das 17 afirmações), anuncie qual foi a equipa vencedora. Pergunte por que razão existem tantos mitos sobre o sexo e o comportamento sexual.
Se prevê uma sessão de perguntas / respostas de seguimento:

5 Distribua folhas de papel em branco e explique:

- A maior parte das pessoas tem perguntas ou dúvidas sobre o sexo e o comportamento sexual. Nos vossos pedaços de papel podem escrever quaisquer perguntas que tenham sobre estes tópicos. Não escrevam o vosso nome, mas sejam suficientemente maduros para fazer perguntas sérias. Se não tiverem perguntas, escrevam "Neste momento não tenho nenhuma pergunta."

- Quando terminarem, dobrem o papel ao meio.

- Mais tarde, irei responder a todas as perguntas sérias. Confio que não vão submeter perguntas imaturas ou impróprias que sejam piadas; essas perguntas não serão respondidas.

6 Após alguns minutos, peça aos alunos que dobrem o papel e depois circule pela sala para recolhê-los num envelope grande ou caixa. Depois de os alunos terem saído, analise as perguntas. As que não conseguir responder com confiança, obtenha as respostas de uma fonte digna de confiança para que possa dar a informação correcta na sessão de respostas.

Reserve tempo numa sessão posterior para responder às perguntas dos alunos. 


\section{COMPORTAMENTO SEXUAL - VERDADEIRO OU FALSO?}

\section{Ler as afirmações e decidir se são verdadeiras (V) ou falsas (F). Assinalar a sua resposta no espaço à direita.}

V ou F?

\begin{tabular}{|c|c|}
\hline 1 & A masturbação é prejudicial. \\
\hline 2 & Se uma rapariga não sangrar a primeira vez que tiver relações sexuais, significa que não é virgem. \\
\hline 3 & Cabe ao homem iniciar as relações sexuais. \\
\hline 4 & As pessoas podem fazer amor e ter orgasmo sem praticar o acto sexual. \\
\hline 5 & A masturbação é frequentemente um problema. \\
\hline 6 & Muitas mulheres não têm orgasmos apenas do sexo vaginal. \\
\hline 7 & A primeira vez que uma mulher tiver relações sexuais será doloroso. \\
\hline 8 & A masturbação ajuda as pessoas a conhecer e a entender a resposta do seu corpo ao estímulo sexual. \\
\hline 9 & Uma pessoa homossexual quer ter relações sexuais com qualquer pessoa do mesmo género. \\
\hline 10 & Logo que um homem fica excitado sexualmente, não consegue controlar-se e deve ejacular. \\
\hline 11 & A maneira mais simples de agradar o seu parceiro/a sua parceira é conversar sobre o que ele/ela gosta e o que é bom para ele/ela. \\
\hline 12 & Uma pessoa pode contrair uma infecção transmitida sexualmente (ITS) a partir do sexo oral. \\
\hline 13 & Muitos homens perdem a sua erecção durante uma experiência sexual em algum momento das suas vidas. \\
\hline 14 & Se um homem tiver um pénis grande, o seu parceiro sentirá mais prazer. \\
\hline 15 & Uma mulher que goste muito de praticar relações sexuais não pode merecer a confiança de que é fiel ao seu parceiro. \\
\hline 16 & A idade certa para ter relações sexuais é 18 anos. \\
\hline 17 & Se um homem puder manter o acto sexual vaginal durante tempo suficiente, a mulher chegará ao orgasmo. \\
\hline
\end{tabular}




\section{respostas a "comportamento sexual - verdadeiro ou falso?"}

1 Falso A masturbação não é prejudicial; pelo contrário, é segura e uma boa maneira de conhecer o seu próprio corpo. Contudo, é uma escolha pessoal. A maior parte das pessoas masturba-se, mas algumas optam por não fazê-lo e outras ainda não se sentem à vontade com a ideia.

Algum sangramento é causado pelo rompimento do hímen. No entanto, o hímen pode facilmente esticar-se ou romper-se durante a actividade física normal ou a prática de desporto e pode ser esticado até se abrir pelos dedos ou tampões. A ausência de hímen ou sangramento não significa que uma rapariga teve relações sexuais.

Em muitas culturas, os homens têm o papel de iniciar as relações sexuais e é suposto as mulheres serem mais passivas sexualmente. Porém, este padrão reflecte certas atitudes culturais sobre os papéis de género. Com efeito, as mulheres também podem iniciar o acto sexual. Até as mulheres que seguem papéis de género tradicionais muitas vezes desenvolvem uma forma indirecta de comunicar o seu desejo sexual aos seus parceiros.

4 Verdadeiro Fazer amor pode traduzir-se em muitos comportamentos (acariciar, beijar, massajar, estímulo manual). As pessoas podem atingir o orgasmo tocando ou friccionando um no outro sem que haja acto sexual.

5 Falso

Não há problemas em masturbar-se com frequência. A única altura em que a masturbação pode ser considerada um problema é se interferir com outras coisas que a pessoa devia estar a fazer, ou se a pessoa perturbar os outros, ou de outro modo causar danos em si própria.

6 Verdadeiro A maioria das mulheres não atinge o orgasmo apenas através do acto sexual vaginal. Pelo contrário, elas atingem o orgasmo através do estímulo do clítoris. É mais provável que as mulheres atinjam o orgasmo se elas (ou o parceiro) estimularem o clítoris directamente antes, durante ou depois do acto sexual vaginal.

7 Falso

A primeira vez que uma mulher tiver relações sexuais pode, ou não, ser doloroso. Para minimizar o desconforto ou a dor, os parceiros devem dedicar algum tempo a explorar os corpos um do outro e ficar totalmente excitados antes da penetração para que a vagina da mulher esteja bem lubrificada. Se a mulher se sentir nervosa ou com medo, o casal poderá esperar.

8 Verdadeiro A masturbação é uma das melhores formas de conhecer e entender como o corpo responde ao estímulo sexual. Pode ajudar as mulheres e as raparigas a aprender como atingir o orgasmo.

9 Falso Todas as pessoas, sejam elas heterossexuais, homossexuais ou bissexuais, são sexualmente atraídas apenas por certas pessoas. A atracção sexual baseia-se em muitos factores. 


\section{respostas a "comportamento sexual - verdadeiro ou falso?"}

10 Falso Alguns homens acreditam que se estiverem realmente excitados sexualmente têm que atingir o orgasmo, mas isto não é verdade. Interromper pode causar algum desconforto, mas o desconforto diminuirá por si. Qualquer pessoa - homem ou mulher - pode interromper a qualquer momento da experiência sexual.

11 Verdadeiro Todas as pessoas têm as suas próprias preferências no que diz respeito à excitação sexual. Ao invés de adivinhar o que o parceiro de alguém gosta ou acha agradável, é mais rápido e mais seguro perguntar-lhe. A comunicação é fundamental para se ter um relacionamento sexual positivo que traga prazer para ambos os parceiros.

12 Verdadeiro O sexo oral pode resultar na transmissão de várias ITS. Esta lista de ITS inclui herpes, gonorreia, vírus do papiloma humano (que provoca verrugas ou cancro), sífilis, clamídia, hepatite B e cancróide, assim como o HIV.

13 Verdadeiro Muitos homens passarão por esta experiência em algum momento das suas vidas. É normal e nada de preocupante. A ansiedade em relação a essa situação aumenta a probabilidade de voltar a ocorrer.

14 Falso Um pénis grande não dá à mulher mais prazer durante o acto sexual. Embora as mulheres sejam diferentes, a maioria diz que o que importa é o que o homem faz, não o seu tamanho. Com efeito, um pénis muito grande pode ser desconfortável ou até doloroso para a mulher.

15 Falso Apreciar o sexo é natural tanto para homens e mulheres. A maneira como a pessoa aprecia o sexo não tem nada a ver com a sua idoneidade. A ideia por detrás deste mito de que as mulheres não deviam gostar do sexo reflecte o padrão duplo de que é aceitável e esperado que os homens, não as mulheres, gostem de sexo. A ideia é injusta, incorrecta e um estereótipo.

16 Falso Não existe idade certa para ter relações sexuais. Cada pessoa tem de determinar quando se sente pronta para tal. A prontidão depende do nível de maturidade da pessoa, do seu relacionamento, valores e sentimentos. Os países têm leis sobre a idade em que uma pessoa é considerada com idade suficiente para poder consentir o sexo.

17 Falso O acto sexual vaginal não leva ao orgasmo para muitas mulheres, independentemente de quanto tempo o homem continua; mais frequentemente, as mulheres atingem o orgasmo em resultado do estímulo directo do clítoris. Uma comunicação honesta entre os parceiros contribuirá para que sintam que a actividade sexual é uma fonte de prazer. 


\section{porque fazemos (ou não fazemos): exercício de escolha forçada sobre a tomada de decisão sexual}

VISÃO GERAL: Os estudantes devem escolher se concordam ou não concordam com uma série de afirmações sobre as razões que levam as pessoas a escolher ter - ou não ter - relações sexuais.

OBJECTIVOS: Permitir que os estudantes reflictam de maneira crítica sobre o seu poder de decisão

(e dos outros) relacionado com o sexo; fortalecer as habilidades pessoais de reflexão e escrita.

\section{INSTRUC̣ÕES}

RACAO:

35-40 minutos

\section{MATERIAL:}

Quadro + giz; lista de

"Afirmações de Escolha

Forçada."

\section{PREPARAC̣̃̃O:}

Apagar quaisquer afirmações sobre escolha forçada que sejam inadequadas e acrescentar quaisquer que tenham significado. De um lado do quadro, escrever "Concordo" e do outro escrever "Discordo."

1 Apresente a actividade:

- Hoje vamos discutir algumas das razões que fazem com que as pessoas decidam ter, ou não, relações sexuais. Muitas circunstâncias e sentimentos diferentes influenciam as decisões das pessoas sobre se devem ter relações sexuais ou não. Por vezes, as pessoas podem ter sentimentos mistos.

- Para explorar este tópico, vou ler algumas afirmações. Trata-se de afirmações sobre valores e não existe resposta certa ou errada para qualquer uma delas. Em relação a cada afirmação, caso concordem, dirijam-se para o lado que diz "Concordo." Se não concordarem, dirijam-se para o lado que diz "Discordo." "Forcem-se" a escolher um lado ou o outro, mesmo que a vossa opinião esteja algures entre os dois lados. Em seguida, algumas pessoas podem apresentar os seus pontos de vista. [Verificar se todos entendem as regras.]

2 Leia cada afirmação. Depois de cada uma delas, dê tempo aos alunos para se dirigirem ao seu "lado." Peça dois comentários de cada lado e depois avance para a afirmação seguinte, mesmo que a conversa não tenha chegado ao fim. Leia as afirmações que o tempo permitir.
3 Reserve cinco a dez minutos para resumir, fazendo as seguintes perguntas:

- Porque é importante que um jovem pense claramente sobre as razões da sua escolha de ter, ou não, relações sexuais? [Sondar o seguinte: sensação de conforto, segurança, voluntariedade e prazer, assim como proteger a saúde.]

- Os jovens têm muitas razões diferentes quando escolhem ter, ou não, relações sexuais. Que tipo de mal-entendidos ou problemas podem resultar destas diferenças de razões?

- Muitas vezes as pessoas não estão cientes de todas as suas motivações e sentimentos, ou não analisaram as suas circunstâncias. Quais são algumas formas que nos podem tornar mais cientes do que se passa, de como nos sentimos e do que queremos e não queremos? [Sondar o seguinte: escrever num diário, conversar com alguém de confiança, pensar honestamente.]

Trabalho de Casa: Escrever dois ou três parágrafos sobre qualquer tópico (não necessariamente sobre sexo) em relação ao qual tenham uma mistura de sentimentos, ou que tenham dificuldades em decidir. 


\section{afirmações de "escolha forçada"}

1 Sinto pelos rapazes porque eles têm que agir como se quisessem sempre ter relações sexuais, mesmo que não queiram.

2 Se uma rapariga gostar do seu namorado, deve demonstrá-lo tendo relações sexuais com ele.

3 Acho que a maior parte dos adolescentes tem sentimentos contraditórios em relação ao sexo; querem e não querem ter relações sexuais ao mesmo tempo.

4 Acho que não há problema em dar algum dinheiro ou presente a alguém em troca de sexo.

5 Acho que não há problema em aceitar dinheiro em troca de sexo se a pessoa precisar do dinheiro.

6 Acho que um homem que é homem assume riscos e é sexualmente agressivo.

7 As imagens da televisão e das revistas fazem com que os jovens sintam que devem ter relações sexuais.

8 Pressionar alguém a praticar o acto sexual contra a sua vontade, mesmo que não seja usada força física, é mais ou menos o mesmo que violação.

9 Algumas raparigas agem como se estivessem apenas à procura de prazer sexual, sem envolvimento, emocional, mas bem lá no fundo, não é o que elas querem; elas realmente querem uma ligação emocional.

10 Muitas raparigas que conheço praticam relações sexuais porque se sentem obrigadas a fazê-lo.

11 As pessoas que se sentem atraídas por outras do mesmo sexo devem esperar mais tempo (com mais idade) do que os seus pares heterossexuais para começarem a viver experiências sexuais.

12 Muitos jovens simplesmente não querem ter relações sexuais. O seu sentimento não tem nada a ver com o SIDA ou a gravidez, nem com o que os adultos Ihes dizem. Pura e simplesmente não querem praticar relações sexuais, mesmo que tenham um namorado ou namorada.

13 O acto sexual é sempre uma experiência extremamente íntima e pessoal para as duas pessoas envolvidas.

14 Muitas pessoas que decidem ter relações sexuais lamentam mais tarde.

15 Muitas pessoas que decidem não ter relações sexuais lamentam mais tarde.

16 Antes de ter relações sexuais, a maioria dos adolescentes fala cuidadosamente com o parceiro sobre se os dois se sentem à vontade e querem ter relações sexuais, e também sobre como se devem proteger das infecções e da gravidez. 


\section{onde se estabelece a fronteira? continuum entre a escolha e a coacção sexual}

VISÃO GERAL: Os alunos colocam os estudos de caso no continuum entre o sexo forçado e o sexo voluntário e desejado e discutem o direito de dizer não. (Nota: Eles devem ter algum grão de compreensão sobre a violência sexual e o consentimento antes da realização desta actividade).

OBJECTIVOS: Permitir que os alunos descrevam o continuum de escolhas sexuais; reconhecer casos em que as relações sexuais são voluntárias, mas não desejadas; entender com clareza o direito de dizer "não" ao sexo; fortalecer as habilidades de pensamento abstracto.

DURACÃO:

45 minutos

\section{MATERIAL:}

Quadro + giz; cópias

dos estudos de caso seleccionados; uma corda comprida ou fita resistente; clips de papel (ou fita-cola); marcadores coloridos, se houver.

\section{PREPARAC̣ÃO:}

Alterar a ficha conforme indicado (ver "Estudos de Caso sobre a Escolha Sexual e a Coacção Sexual"). Tirar quatro cópias do conjunto de estudos de caso que forem seleccionados. Alterar a

ficha conforme indicado (ver "Estudos de Caso sobre a Escolha Sexual e a Coacção Sexual"). Tirar quatro cópias do conjunto de estudos de caso que forem seleccionados.

\section{INSTRUCÕ̃ES}

1 Prenda a fita horizontalmente na sala. Numa extremidade coloque o rótulo: "Totalmente forçado, não desejado" e na outra o rótulo: "Totalmente voluntário, desejado."

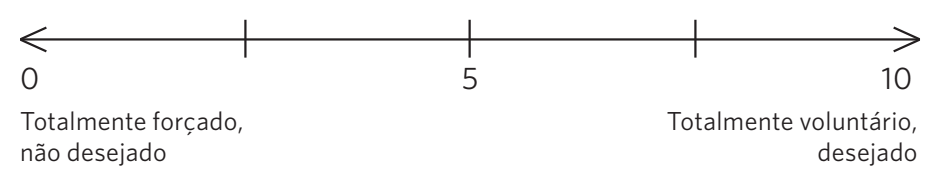

2 Introduza o tópico e explique que existe um continuum entre o sexo que é forçado e totalmente indesejado e o sexo que é totalmente voluntário e desejado. Pergunte:

- Como chamamos o sexo que é forçado? Depois de responderem, acrescente a palavra "estupro" nessa extremidade do continuum.

- Se uma pessoa aceitar relações sexuais, será que isso significa que ele ou ela realmente quer ter relações sexuais? Depois de os alunos responderem, pergunte: Quando o sexo é voluntário, mas não realmente desejado, essa situação estaria numa extremidade da fita ou algures entre as duas extremidades?

3 Divida os alunos em quatro grupos. Dê a cada grupo a ficha e um conjunto de clips de papel. Explique:

- Leiam cada cenário no vosso grupo.

Seguidamente, conversem sobre o assunto e decidam onde na fita - o continuum de $0-10-$ acham que o estudo de caso se enquadra.

- Marquem o caso com os vossos nomes [com um marcador colorido, se possível]. Em seguida, fixem com um clip no lugar da fita onde decidiram que se enquadra.

4 Circule pelos grupos e ofereça ajuda. Deixe que levem mais tempo a discutir os seus pontos de vista, mesmo que não concluam todos os estudos de caso. 
5 Passados 15 minutos, peça a alguém de um grupo que leia o primeiro estudo de caso e explique onde no continuum de 0-10 o grupo o colocou e porquê. Dê dois a três minutos aos outros grupos para indicarem onde o colocaram no continuum; incentive a discussão de quaisquer diferenças de opinião. Repita este processo com cada estudo de caso.

6 Reserve dez minutos no fim para discutir as seguintes questões:

- Forçar alguém a ter relações sexuais não desejadas é uma violação dos direitos humanos dessa pessoa. Erguendo os braços, quem acredita que o sexo forçado é comum entre os jovens? Quem acha que é raro?

- Discutimos que uma pessoa que não queira ter relações sexuais, e não é para tal forçada, pode voluntariamente praticar relações sexuais. Quem acredita que esta é uma experiência bastante comum entre os jovens? Quem acha que é raro? [Anotar se os rapazes respondem a esta pergunta de forma semelhante à das raparigas.]

- As raparigas e os rapazes têm igual probabilidade de ter relações sexuais numa situação que não seja forçada, mas também não desejada? [Sondar o seguinte: Acham que as raparigas e os rapazes normalmente partilham o mesmo poder no relacionamento sexual? E os homense mulheres adultos?] [Nota: Sublinhar que mesmo que uma situação não se enquadre na extremidade "forçado" do espectro, pode, não obstante, ser inaceitável.]
- Uma pessoa sabe sempre se o seu parceiro realmente pretende ter relações sexuais? Quais são algumas formas de se certificar? [Sondar o seguinte: Perguntar a pessoa! Conversar antes é melhor. E se perguntarem e o vosso parceiro não tiver a certeza do que quer?] 


\section{estudos de caso sobre a escolha sexual e a coacção sexual}

INSTRUÇÕES PARA O PROFESSOR: Seleccione seis a oito dos seguintes estudos de caso (ou escreva os seus próprios estudos de caso). Certifique-se de que a sua selecção final inclui pelo menos um caso em que um rapaz se sinta pressionado a ter relações sexuais. Modifique-os de modo a que sejam adequados e tenham significado para os seus alunos.

MOHAMMED e AMMA: Mohammed quer ter relações sexuais, mas a mulher, Amma, não está com vontade esta noite. Ela foi ensinada que é dever da esposa ter relações sexuais sempre que o marido desejar, a menos que se sinta doente ou que esteja a menstruar, pelo que ela tem relações sexuais com Mohammed.

NINA e CARL: Nina, de 22 anos, namora com Carl há cerca de seis meses. Ele disse-lhe várias vezes que realmente quer ter relações sexuais, mas só se ela quiser. Nina sente-se insegura, mas acha que devia fazer o que o namorado quer. Ela sabe que outras jovens têm relações sexuais com os seus namorados e está preocupada que ele a possa deixar se ela não o fizer, embora Carl nunca tenha ameaçado fazê-lo. A próxima vez que se encontrarem numa situação íntima, têm relações sexuais.

JACOB e GRACE: Jacob e a namorada, Grace, estão sozinhos em casa dos pais dele. Jacob, que está embriagado e a balbuciar as palavras, está deitado no chão. Grace, que também bebeu um pouco, está deitada perto dele. Sentindo-se desinibida, ela toma a iniciativa e pratica o sexo oral com ele. Jacob sente-se confuso e não sabe o que dizer. No dia seguinte, não se lembra de nada.
HENRY e MARIA: Henry e Maria estão a beijar-se apaixonadamente. Quando Henry começa a despir Maria, ela tenta travá-lo e diz "Não." Henry pensa que ela quer mais mas tem receio de admiti-o. Então continua a tentar. Depois de tentar afastar Henry e de dizer "não" durante cinco minutos, ela acaba por parar de resistir e limita-se a ficar deitada. Henry avança e tem relações sexuais com ela.

AJIT e ANILA: Ajit e Anila encontraram-se umas poucas vezes, sempre com supervisão. Ajit parece ser uma boa pessoa, pelo que Anila concorda quando os pais lhe dizem que Ajit quer se casar com ela. Anila foi ensinada que tudo o que está relacionado com o sexo é vergonhoso. Ouviu dizer que a primeira vez é dolorosa e provoca sangramento. Ela está com medo. Ela mal conhece Ajit e sente-se envergonhada só com a ideia de ele tocar o seu corpo. Não está interessada em ter relações sexuais e não se sente animada, mas sabe que quando a pessoa se casa, deve praticar o acto sexual na noite de núpcias. Ela deixa que Ajit tenha relações sexuais com ela. 


\section{estudos de caso sobre a escolha sexual e a coacção sexual}

SELAH e JAMES: A última vez que Selah se recusou a ter relações sexuais com o marido, James, ele ameaçou-a e bateu-lhe muito, deixando-a com um olho negro. Ela não quer ter relações sexuais com James hoje, mas ele poderá voltar a bater-lhe e, por essa razão, não se recusa.

LIN e YANG: O namorado de Lin, Yang, está realmente a pressioná-la a ter relações sexuais. Ela sabe que realmente não quer, mas veio com Yang sozinha para este local isolado. Pensando que é inevitável, limita-se a deixar que Yang faça o que quer, sem dizer nada.

TEO e HELENA: Teo e Helena são colegas de turma na universidade. Namoram há alguns meses e sentem-se muito atraídos um pelo outro. Não estão profundamente apaixonados, mas concordam que querem praticar relações sexuais. Depois de Teo aceitar usar o preservativo, eles têm relações sexuais.

GINA e AHMED: Gina vem de uma família pobre. Ela trabalha numa loja para Ahmed e o seu salário é o principal rendimento da família. Um dia, Ahmed começa a tocá-la e depois de a loja fechar, empurra-a para o armazém nas traseiras e levanta o vestido dela. Gina está confusa e assustada com a possibilidade de perder o emprego. Ela começa a resistir, mas quando Ahmed diz "O quê? Não gostas de trabalhar aqui?", ela cede.
JULIA e OSCAR: Oscar não tem a certeza se realmente quer praticar o acto sexual com Julia, mas Julia sugeriu e ele receia que os amigos descubram e façam troça dele se disser que não. Ele avança.

PETER e LAURA: Peter muitas vezes compra presentes para Laura e outras coisas de que ela necessita. Esta noite foram jantar fora e ele pagou. Embora Laura não se sinta preparada para ter relações sexuais, ela sente que o deve a Peter. Não recusa.

VERA e WILLIAM: Vera e William já tiveram relações sexuais antes. Esta noite, William diz a Vera que a desejou todo o dia. Vera prefere antes passear e conversar, mas acha que uma vez que já o fizeram uma vez, não há como voltar para trás. Quando William começa a despir-se, Vera não diz nada e eles têm relações sexuais.

EMMA e ROBERT: Uma noite, Emma bebeu muito. Robert encontra-a deitada na cama desmaiada e com frio. Ele tira-lhe a roupa e tem relações sexuais com ela. Ela não acorda. 


\section{a questão do consentimento}

\section{DURAC̣ÃO:}

Etapas 1-6: 45 minutos

Etapas 7-8: 45 minutos

\section{MATERIAL:}

Quadro + giz; estudos de caso seleccionados; informação para o mapa dos professores; chave de respostas.

\section{PREPARAC̄̃̃:}

Seleccionar 4-6 estudos de caso que reflectem situações comuns no seu contexto e adaptá-las mudando os nomes ou outros detalhes. Ou então criar estudos de caso alternativos. Usar alguns estudos de caso em que os personagens conseguem dar consentimento livre e informado e alguns em que não conseguem. Se for necessário, rever a

informação contida no mapa dos professores. Escrever instruções no quadro com antecedência. Procurar saber o que a lei do país diz em relação à idade de consentimento da actividade sexual.
VISÃO GERAL: Os alunos aprendem sobre o conceito de consentimento sexual. Exploram este conceito nos estudos de caso, em breves peças de teatro e nas discussões que realizam.

OBJECTIVOS: Ajudar os alunos a entender e a valorizar a importância do consentimento em qualquer situação sexual; fortalecer as habilidades de pensamento abstracto.

\section{INSTRUC̣ÕES}

1 Apresentar a actividade com a seguinte explicação e perguntas:

- Todos nós temos responsabilidades, por exemplo, em casa, na escola e no nosso trabalho. No entanto, por vezes é-nos solicitado ou dito para fazer algo (pelos pares ou até pelos adultos) que não faz parte das nossas responsabilidades, o que nos pode confundir ou perturbar.

Opção: Para apresentar este conceito mais detalhadamente, alargar a discussão como se segue abaixo:

O que significa consentir algo? [Sondar o seguinte: concordar, indicar ou manifestar uma vontade.] Consentimos fazer coisas por razões diferentes: por vezes, consentimos fazer alguma coisa porque queremos fazê-la, por exemplo, se um amigo vos convida a jogar futebol e vocês querem jogar. Ou podemos consentir fazer algo que realmente não queremos fazer, mas concordamos porque é importante para nós por qualquer motivo, por exemplo, quando o professor vos dá trabalho de casa que não querem fazer, mas fazem porque querem ter um bom aproveitamento na escola.
Porém, por vezes fazemos coisas que não queremos apenas porque é difícil defendermonos, ou então não queremos ser indelicados. Esta situação pode estar relacionada com algo que não é muito importante, como por exemplo, comer algo que uma pessoa não gosta porque alguém a cozinhou para nós. Outras vezes pode tratar-se de uma questão mais séria, com consequências graves. Quais são alguns exemplos de coisas sérias que um jovem pode consentir ou não consentir fazer? [Se os alunos não mencionarem sexo, sugerir que se adicione à lista.]

- Levantem os braços se alguma vez aceitaram fazer algo que não era da vossa responsabilidade e que realmente não queriam fazer. Quem pode dar um exemplo?

- Quais são algumas razões que podem levar uma pessoa a aceitar fazer alguma coisa que realmente não queira fazer? Escrever as respostas no quadro.

- Hoje vamos começar a olhar para o significado de dar um consentimento verdadeiramente livre e informado numa situação que envolve relações sexuais. 
2 Pergunte (e escreva as respostas no quadro):

- O que significa a palavra "consentimento"?

- O que significa "consentimento livre e informado"?

3 Peça aos alunos que leiam em voz alta as orientações para se dar um consentimento livre e informado numa situação sexual.

4 Constitua pequenos grupos para que cada um tenha um estudo de caso diferente. Dê a cada grupo o respectivo estudo de caso e explique:

- Têm 10 minutos. Analisem o vosso estudo de caso, preparem uma breve peças de teatro (de 2-3 minutos) e considerem qual das orientações para o consentimento foram, ou não, seguidas nesta situação.

- Uma pessoa deve ler o estudo de caso para toda a turma, outras duas podem representá-lo, e uma ou duas pessoas devem explicar que orientações para o consentimento foram seguidas e quais não foram. [Dar 10-20 minutos para esclarecer a tarefa e para os grupos prepararem. Circular pelos grupos para ajudar, se for necessário.]

5 Peça a um grupo que apresente a) o seu estudo de caso; b) a sua peça de teatro e c) a sua opinião colectiva sobre se a pessoa deste estudo de caso conseguiu dar um consentimento livre e informado.

6 Pergunte quem concorda, ou não, com a opinião do grupo de que as orientações sobre o consentimento foram observadas. Discutir até que se chegue a um acordo sobre a resposta correcta.

7 Repita as etapas 5 e 6 para cada grupo/estudo de caso. Dar 10-12 minutos por caso.
8 Encerrar dinamizando uma discussão: Sabemos que existem circunstâncias em que uma pessoa não tem o controlo nem o poder para dizer não. Esta é uma violação dos direitos humanos.

- Em muitos casos, o grau de controlo ou de poder que uma pessoa tem não está claro ou pode estar aberto à negociação. Em certas situações, pode fazer a diferença apenas entenderem nos vossos corações que têm o direito de consentir ou não nas relações sexuais. Este é um exemplo de conhecimento como poder.

- Uma pessoa pode ter a certeza se o seu parceiro consente sem falar com essa pessoa? Porquê ou porque não? O que se pode fazer para ter a certeza que a pessoa que está a "consentir" no acto sexual está a fazê-lo livremente e de maneira informada?

Trabalho de Casa: Coloquem-se no lugar de alguém que teve relações sexuais indesejadas por se sentir pressionado. Esta pode ser a pessoa de um estudo de caso que leram ou de que ouviram falar hoje, ou pode ser alguém que conheçam que se tenha encontrado numa situação em que o consentimento no acto sexual foi inadequado (não usar o seu nome verdadeiro). Escrevam um discurso na voz dessa pessoa, focalizem nos seus sentimentos, e não precisamente no que aconteceu sexualmente. Pensem em quaisquer diferenças de poder no relacionamento que tenham feito com que a pessoa se sentisse pressionada. $\mathrm{O}$ vosso objectivo ao escrever o discurso deve ser ajudar a pessoa a "reconquistar" o seu sentido de controlo e de poder igual. Se preferirem, poderão escrever o discurso em forma de poema. 


\section{orientações sobre como dar o consentimento numa situação que envolva o acto sexual}

Acreditem que têm o direito de decidir por vós próprios se querem, ou não, participar numa determinada actividade sexual.

Tenham um sentido de poder suficiente e controlo adequado da vossa própria vida para conseguirem comunicar e implementar a vossa decisão.

Tenham a maturidade necessária para entender o que uma actividade implica e que consequências podem advir dela, bem como a maturidade para comunicar com o vosso parceiro sobre estas questões.

Estejam numa situação ou relacionamento em que a vossa decisão será reconhecida e respeitada pelo vosso parceiro.

Saibam o que a actividade implica e quais são os vossos sentimentos em relação a ela; quais são os riscos; como se podem proteger e o vosso parceiro da gravidez indesejada e da infecção.

Tenham mente clara, não prejudicada pelo álcool ou drogas na altura da tomada de decisão.

Tenham informação exacta sobre o actual estado de saúde sexual do vosso parceiro (incluindo sobre qualquer exposição sexual anterior ou consumo de drogas que possa representar um risco).

Tanto quanto for possível, evitem situações em que exista a probabilidade de pressão para a prática de relações sexuais não desejadas por razões materiais ou financeiras. 


\section{estudos de caso: esta pessoa pode dar o seu consentimento?}

A Ana tem 19 anos e o namorado, Al, 22. Namoram há seis meses e têm relações sexuais há cerca de um mês. Ana normalmente gosta de sexo, mas por vezes não tem vontade. Nessas alturas, Al muitas vezes diz-lhe coisas como "Se realmente me amasses, havias de querer" ou "Se não quiseres ter relações sexuais comigo, talvez tenha que arranjar alguém que queira". Ela não quer perdê-lo, por isso muitas vezes cede. Ana pode dar um consentimento livre?

B Beni sabe que está infectado pelo HIV, mas não disse a ninguém. Tem saído com a Bea e recentemente têm conversado sobre a prática de relações sexuais. Beni tem planos de usar o preservativo, em vez de dizer a Bea que é seropositivo. Bea pode dar um consentimento livre e informado?

C Carlo e Clea estão na casa dos vinte anos. Namoram há cerca de um ano e conversaram honestamente sobre os seus relacionamentos no passado. Gostariam de praticar relações sexuais um com o outro. Conversaram sobre o assunto e concordaram em ir a uma clínica para obter informação e depois decidir como manter-se seguros e evitar quaisquer consequências indesejadas. Clea pode dar um consentimento livre e informado?

D Dom e Deenah têm 18 anos e decidiram ter relações sexuais. Deenah diz que tem medo de engravidar, mas Dom garante-lhe que não é possível engravidar na primeira relação sexual. Deenah pode dar um consentimento livre e informado?

E Eva tem 14 anos e está na escola secundária. Edo tem 18 anos e trabalha com o pai de Eva. Edo conheceu Eva quando visitou a casa dela. Edo e Eva também começaram a encontrar-se fora da casa dela. Às vezes, Edo oferece presentes e dinheiro a Eva, se ela precisar. Ultimamente, ele começou a dizer-lhe o quanto a amava e que realmente queria ter relações sexuais com ela. Eva pode dar um consentimento livre e informado?

F Finn tem 18 anos e gostaria de ter relações sexuais com a namorada, Fatima, que tem 17. Conversaram sobre o facto de que nenhum deles tinha tido relações sexuais antes. Ele decide ler um livro que a mãe, que é médica, tem sobre o crescimento, sexo, planeamento familiar e ITS. Ele pergunta à namorada o que ela acha e oferece-se para lhe emprestar o livro. Ela lê o livro e voltam a conversar sobre o assunto. Ela diz que prefere esperar e Finn concorda. Fatima pode dar um consentimento livre e informado? 


\section{estudos de caso: esta pessoa pode dar o seu consentimento?}

G Gia, de 24 anos, está numa festa em casa de alguns estudantes e está a beber muito. O parceiro dela, com quem já teve relações sexuais, puxa-a para um quarto e começa a despi-la. Gia ora está consciente, ora está inconsciente. Gia pode dar um consentimento livre e informado?

H Halle foi ensinada pela mãe que é importante que uma mulher faça o que quer que o marido exija dela, se não quiser perdê-lo. Ela está comprometida para se casar com Hugh e ele diz que agora que estão noivos, podem ter relações sexuais. Halle acredita fortemente que devia esperar e quer casar virgem, mas pensa: "Ele será meu marido e a minha mãe diz que devo obedecê-lo". Halle pode dar um consentimento livre e informado?

I Isaac já teve vários parceiros, mas deixa que Ivan, o seu novo namorado, acredite que ele ainda é virgem, tal como Ivan. Quando têm relações sexuais, Ivan aceita não usar o preservativo, pensando que não existe risco de infecção. Ivan pode dar um consentimento livre e informado?

J Jin tem 20 anos e Josef 19. Há cerca de seis meses, Jin perguntou a Josef, seu namorado, se queria ter relações com ela. Eles são abertos e honestos um para com o outro, então ele disse-lhe que receava as consequências e que não se sentia pronto. Ele disse que gostaria apenas de beijá-la e que se tocassem por agora. Jin realmente queria experimentar o acto sexual, mas concordou com Josef. Agora Josef acha que está pronto. Pergunta a Jin onde podem obter mais informações para evitar qualquer risco. Josef pode dar um consentimento livre e informado? 


\section{respostas a "estudos de caso: esta pessoa pode dar o seu consentimento?"}

Nota: Devem saber se a lei do seu país estabelece uma idade mínima para dar o consentimento para a actividade sexual de modo a que possam avaliar se as pessoas em cada cenário têm idade suficiente para consentir no acto sexual. Altere os cenários ou as respostas com base nessa informação.

A Não Al não respeita a decisão de Ana quando ela diz que não quer ter relações sexuais. Ela também não acredita com firmeza que tenha o direito de decidir por si própria e não tem o sentido de poder suficiente no relacionamento para conseguir implementar a sua escolha.

B Não Bea não tem informação exacta sobre o estado de saúde sexual do seu parceiro.

C Sim Ambos decidiram por si próprios e estão de acordo; estão a tomar a decisão com mente clara; nenhum motivo material ou financeiro os está a influenciar; conseguem comunicar a sua decisão, sabem quais são as implicações e sabem que precisam de ter protecção; conversaram honestamente sobre o seu comportamento no passado; e têm idade suficiente, por lei, para consentir no acto sexual.

D Não Deenah não sabe quais são os riscos, nem como se proteger.

E Não O consentimento sexual de uma pessoa de 14 anos raramente é significativo por causa da sua maturidade ainda em desenvolvimento. Preocupações em relação à maturidade e direitos da criança levaram à criação de legislação que define uma idade mínima para o consentimento sexual e proíbe o casamento infantil.

F Sim Fatima acredita que tem o direito de decidir por si própria se deve ter relações sexuais e o parceiro respeita a sua decisão. Ela está a tomar a decisão com mente clara; não tem um motivo económico ou material que a pressione; consegue comunicar e implementar a sua decisão; sabe o que está em causa, quais são os riscos e como se proteger. Tem informação exacta sobre o comportamento sexual anterior do seu parceiro. Na maioria dos países, ela seria considerada com idade suficiente para tomar a decisão de ter relações sexuais se assim decidir, mas consultem as leis em vigor onde vivem.

G Não Gia está embriagada e quase inconsciente. Não consegue decidir por si própria e o seu parceiro não está a comunicar com ela.

H Não Halle sabe o que quer, mas não parece acreditar no seu direito de decidir por si própria, ou não tem um sentido de poder e controlo suficiente sobre a sua vida para conseguir implementar a sua decisão.

I Não Ivan não tem informação exacta sobre o comportamento sexual anterior do seu parceiro.

J Sim Josef acredita que tem o direito de decidir por si próprio; consegue comunicar e implementar a sua decisão e o seu parceiro respeita essa decisão. Ele não tem um motivo económico ou material imperioso; está ciente dos riscos e pretende informa-se sobre eles e sobre a protecção; legalmente, tem idade suficiente para tomar a decisão. Embora não saibamos se os parceiros discutiram o seu comportamento sexual anterior ou o uso de drogas, sabemos que são abertos e honestos um com o outro. 


\section{tópicos políticos quentes e respostas pessoais}

DURAC̣̃̃:

45 minutos

\section{MATERIAL:}

Quadro + giz; "'Títulos' sobre

Temas Ligados à Política de

Sexualidade."

\section{PREPARAC̣ÃO}

Eliminar certos títulos, caso seja necessário. Copiar os outros

títulos no quadro.
VISÃO GERAL: Os estudantes seleccionam o título de uma notícia que reflicta as normas em mudança sobre a sexualidade e escrevem uma resposta pessoal.

OBJECTIVOS: Ajudar os alunos a entender que as normas sexuais mudam com o tempo; esclarecer os seus próprios valores sobre um tema seleccionado; fortalecer as habilidades de pensamento crítico e de escrita.

\section{INSTRUÇÕES}

1 Apresente a actividade explicando o seguinte:

- As atitudes sobre a sexualidade diferem de uma sociedade para outra. Elas também estão sempre a mudar dentro de qualquer sociedade. Hoje vamos identificar e pensar em algumas das formas como estas atitudes estão a mudar.

- Leiam a lista de títulos no quadro; a maioria foram adaptadas de acontecimentos reais em todo o mundo. Seleccionem um e escrevam uma resposta pessoal de cerca de uma página. Poderão escrever quaisquer pensamentos ou sentimentos que tenham sobre o tópico, mas tentem reflectir profundamente sobre esse tópico. Terminem dizendo qual pensam que será a situação em relação a essa questão dentro de 10 ou 15 anos. Levem cerca de 5 minutos para analisar a lista e 15 minutos para escrever. Em seguida, alguns de vós podem ler a vossa resposta escrita.

2 Para cada título, peça a um voluntário que leia o que escreveu. Depois de cada leitura, agradeça ao aluno. Se for necessário, esclareça qual era a questão e corrija qualquer desinformação flagrante. Incentive a discussão com base em qualquer das seguintes perguntas:
- Quais sentimentos têm após esta leitura?

- Que respostas têm?

- Esta questão é relevante no nosso país?

- Outros comentários?

[Prever dois ou três minutos por título. Alguns títulos podem não ter sido seleccionados; isto permitirá mais tempo para discutir os títulos que foram seleccionados.]

3 Encerre lembrando aos alunos que as normas estão constantemente a mudar. Perguntar:

- As mudanças são sempre para normas mais flexíveis, ou podem tornar-se normas rígidas ou restritivas?

- As normas sociais - sobre a sexualidade ou sobre qualquer outra questão- mudam só por si de forma mágica? O que ou quem leva a uma mudança nas normas sexuais? [Sondar fenómenos sociais alargados (tais como o nível de escolarização superior e órgãos de informação globalizados) e o papel dos indivíduos (líderes públicos e membros da comunidade).]

- As pessoas introduzem estas mudanças sendo modelos, educando os outros e defendendo mudanças de políticas. 


\section{"títulos" sobre temas ligados à política de sexualidade}

Mulher que Instaurou Processo de Assédio Sexual Ganha a Causa; Primeira Vitória desta Natureza nos Tribunais

Abre Clínica do Adolescente; Primeira do Género no Estado

Homens Locais Organizam uma Marcha Contra a Violência Sexual; Homem que é Homem não Viola

Entra em Vigor Lei que Autoriza o Casamento de Homossexuais; Primeiro Casal Contrai Matrimónio às 8:00

Rapariga de Catorze Anos Foge de Casamento Forçado

Raparigas Queixam-se do Código de Vestuário que Exige que Estejam Totalmente Cobertas Permanentemente

Sessenta Jovens do Sexo Masculino Assinam um Compromisso de que Só se Casarão com Raparigas não Circuncidadas

Polícia Prende Homem Seropositivo que Procurava a "Cura” Através de Relações Sexuais com Cinco Virgens

Novo Estudo Mostra que os Pais Continuam a Vender as suas Filhas aos Traficantes Sexuais

Presidente Afirma que a sua Atitude em Relação à Homossexualidade Mudou Depois de saber que a sua Filha era Lésbica

Lei do Aborto Mais Restritiva, Provedores de Serviços de Aborto Presos 


\section{meus relacionamentos}

\section{DURAC̣̃̃O:}

45 minutos

\section{MATERIAL:}

Quadro + giz

\section{PREPARAC̣ÃO:}

Revisão das instruções.
VISÃO GERAL: Os alunos criam uma representação visual dos seus relacionamentos.

OBJECTIVOS: Ajudar os alunos a identificar os diferentes relacionamentos nas suas vidas e apresentar qualidades que prezam em si próprios e que procuram nos relacionamentos próximos; fortalecer as habilidades de pensamento crítico dos alunos.

\section{INSTRUC̣ÕES}

1 Explique aos alunos que vão identificar os vários relacionamentos que têm com as pessoas. Peça aos alunos que elaborem uma lista pessoal dos seus relacionamentos e ligações com outras pessoas.

2 Convide alguns alunos para partilharem as suas listas voluntariamente. Registe no quadro os diferentes tipos de relacionamentos que eles mencionarem, por exemplo os que têm com familiares, amigos ou vizinhos.

3 No quadro, desenhe quatro círculos concêntricos (como o apresentado a seguir).

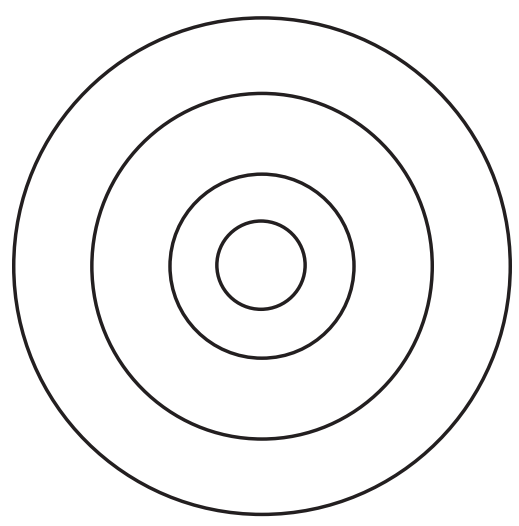

4 Peça aos alunos que tirem uma folha de papel em branco. Explicar:

- Desenhem uma série de quatro círculos, de pequeno a grande, como o que eu desenhei. Utilizem toda a vossa folha para o círculo maior.

- No círculo mais pequeno, escrevam o vosso próprios).

- Pensem em diferentes pessoas na vossa vida. Um pouco fora do círculo mais pequeno, escrevam os nomes (ou desenhem imagens simples) dos que estão mais próximos de vós.

- Nos dois círculos exteriores, coloquem os nomes (ou as imagens) dos que não são tão próximos.

5 Peça aos alunos que constituam grupos de três ou quatro elementos com os que estão sentados mais perto e dê cerca de dois minutos a cada um para explicar o desenho aos outros elementos do seu grupo. nome (ou desenhem uma imagem de vós 
6 Dinamize a discussão com as seguintes perguntas:

- Todos no vosso grupo indicaram o mesmo tipo de relacionamentos ou houve diferenças? Todos colocaram os membros da sua família, amigos, vizinhos, professores, líderes religiosos ou outros no mesmo círculo ou em círculos diferentes?

- Indiquem algumas palavras que descrevam o que prezam nas pessoas de que se sentem mais próximos [Sondar o seguinte: honesto, respeitoso, espírito de partilha, carinhoso, de confiança, divertido, seguro, compreensivo, interessante, amoroso. Escrever estas palavras no quadro.]
7 Reserve dez minutos para os alunos explorarem as qualidades que prezam nos seus relacionamentos:

- Pensem numa pessoa que esteja na vossa página e que gostariam que estivesse mais próxima do interior do círculo. Escolham uma palavra que melhor descreva o que prezam nessa pessoa.

- Agora pensem numa ou duas palavras do quadro que acham que as pessoas diriam que vos descreve.

- Celebrem uma qualidade que mais prezam (em vós próprios ou nos outros) escrevendo-a na vossa folha com letras decorativas ou num estilo criativo.

- À medida que forem escrevendo ou desenhando, pensem no que essa palavra significa para vocês. 


\section{o que se passa com estes dois?}

\section{DURAC̣ÃO:}

45 minutos

\section{MATERIAL:}

Quadro + giz; um estudo de caso por cada grupo pequeno.

\section{PREPARAC̣ÃO:}

Rever os estudos de caso nas FICHAS DO ALUNO e adaptálos ou substituí-los consoante as necessidades de modo a garantir que reflictam formas comuns de desigualdade na vossa sociedade. Fotocopiar cada estudo de caso numa folha de papel diferente.
VISÃO GERAL: Os alunos lêem estudos de caso sobre relacionamentos caracterizados por desigualdades sociais; identificam as desigualdades e discutem o seu efeito nos relacionamentos.

OBJECTIVOS: Ajudar os alunos a identificar como a desigualdade social pode afectar as relações íntimas; fortalecer as habilidades de pensamento analítico.

\section{INSTRUC̣ÕES}

1 Explique:

- Hoje vamos explorar como a desigualdade e as diferenças de poder entre as pessoas podem afectar os nossos relacionamentos. Que formas de desigualdade existem na nossa sociedade entre grupos diferentes? [Sondar o racismo; casta; $e$ desigualdade com base em variáveis como o género, a idade, a classe, a etnicidade, a preferência sexual e a capacidade física.]

- Vão constituir quatro grupos e cada grupo deve ler um estudo de caso. Essa actividade será seguida de perguntas de discussão. Posteriormente, devem dar as vossas respostas às perguntas.

2 Distribua a cada grupo um estudo de caso e uma cópia das perguntas de discussão. Dê-lhes dez minutos.
3 Peça a cada grupo que leia o seu estudo de caso e apresente as suas respostas às perguntas de discussão em cinco a sete minutos. Em seguida, dê alguns minutos para comentários dos outros.

4 Proceda da mesma forma com os outros três estudos de caso.

5 Encerre incentivando os alunos a pensar numa desigualdade na sociedade que se manifesta nas suas próprias relações pessoais e a reflectir nas suas consequências.

Trabalho de Casa: Escrever um postal a uma das pessoas do estudo de caso. Aconselhar a pessoa sobre o que deve fazer para reduzir o impacto da desigualdade na sua relação. 


\section{FICHA DO GRUPO 1:}

Senti-me atraída pelo meu namorado porque ele era mais velho e ninguém o conhecia. Ele parecia misterioso e empolgante. Apaixonámo-nos e agora passamos a maior parte do tempo juntos. Vocês sabem como é. Realmente gosto de ouvir as suas histórias sobre todas as suas experiências. Quando saímos, normalmente ele é quem decide para onde devemos ir porque ele é que paga e conhece todos esses lugares fantásticos. Influenciou-me muito. Nunca me senti interessada em desporto, mas ele adora futebol e, portanto, passo grande parte dos meus tempos livres com ele nos jogos ou a assistir desporto na televisão.

Depois de nos conhecermos há alguns meses, disse-me que queria fazer amor comigo. Eu hesitei, mas achei que me podia deixar se eu não aceitasse. Afinal, ele tem 23 anos e é experiente. Hoje em dia mal vejo os meus amigos. Eles reclamam e dizem que mudei. Sinto a sua falta e, às vezes, penso nos momentos em que eu estudava mais e como gostava de ler. Mas sabem, acho que é o que acontece quando se está apaixonado.

\section{Perguntas:}

1 Existem diferentes tipos de desigualdade entre os grupos da sociedade (por exemplo, as pessoas podem ter um maior ou menor estatuto com base nos seus grupos étnicos ou raciais, classe económica, sexo, idade ou outras características). Que formas de desigualdade estão presentes nesta relação?

2 Que pessoa tem uma posição de mais poder nesta relação em resultado do seu estatuto na sociedade? Qual é a base desta desigualdade? Como é demonstrada a posição mais poderosa?

3 Que pessoa tem a posição inferior nesta relação por causa do seu estatuto social? De que forma é demonstrada esta posição inferior?

4 Que efeito, se houver algum, esta desigualdade tem em cada pessoa? Como afecta a relação?

5 Acham que este tipo de questões existe na nossa comunidade? Favor comentar. 


\section{FICHA DO GRUPO 2:}

No ano passado, comecei a sair com um indivíduo da equipa de rugby da nossa vila. As coisas começaram a ficar sérias entre nós. Numa destas noites, numa reunião no município, fez-me um sinal para me encontrar com ele nas traseiras do edifício. Os meus pais estavam lá, mas eu sabia que eles iriam pensar que estou com as outras raparigas. Eu e ele saímos e fomos dar um passeio nos arbustos das traseiras do município. Quando lá chegámos, beijámo-nos e ele começou a apalpar os meus seios. Eu sabia que íamos ter relações sexuais. Eu realmente não queria. Só queria conversar com ele, beijá-lo, nada mais, mas ele queria e como eu tinha ido com ele, acabamos tendo relações sexuais.

Mais tarde chorei porque sabia que tinha desrespeitado os meus pais e que acabava de perder a minha virgindade. Já tinha ouvido falar de preservativos e que eles podem prevenir a gravidez da rapariga e doenças, mas na altura eu só pensava noutras coisas, como por exemplo a reaç̧ão dos meus pais se soubessem o que eu andava a fazer. Eu estava mais preocupada com o facto de ter perdido a minha virgindade. Quando engravidei, os meus pais ficaram furiosos e proibiram-me de voltar a ver o meu namorado.

\section{Perguntas:}

1 Existem diferentes tipos de desigualdade entre os grupos da sociedade (por exemplo, as pessoas podem ter um maior ou menor estatuto com base nos seus grupos étnicos ou raciais, classe económica, sexo, idade ou outras características). Que formas de desigualdade estão presentes nesta relação?

2 Que pessoa tem uma posição de poder mais forte nesta relação em resultado do seu estatuto na sociedade? Qual é a base desta desigualdade? Como é demonstrada a posição mais poderosa?

3 Que pessoa tem a posição inferior nesta relação por causa do seu estatuto social? De que forma é demonstrada esta posição inferior?

4 Que efeito, se houver algum, esta desigualdade tem em cada pessoa? Como afecta a relação?

5 Acham que este tipo de questões existe na nossa comunidade? Favor comentar. 


\section{FICHA DO GRUPO 3:}

Quando fiz 35 anos, achei que era melhor casar. Finalmente tinha arranjado um emprego e podia sustentar uma família. Tinha concluído a universidade, mas porque havia tanto desemprego, era difícil arranjar um trabalho na minha cidade. Acabei emigrando para arranjar emprego. Quando regressei para visitar a minha mãe, decidi procurar uma mulher na nossa vila. Encontrei-me com várias mulheres jovens e gostei muito de uma delas. Tinha 20 anos na altura e era uma pessoa reservada. Tinha terminado o ensino primário, mas nunca saíra para longe da vila. Embora eu lhe tivesse dito que teria que viver com a minha mãe até eu poder levá-la, ela aceitou casar-se comigo.

Depois de termos o nosso primeiro filho, eu não queria que ela usasse contraceptivos, então passei a usar o método de interrupção. Faço o melhor que posso para cuidar dela e do nosso filho. Ela continua a viver com a minha mãe, mas nunca cria problemas nem diz que precisa de alguma coisa. Amo-a, mas existem coisas sobre as quais não posso falar com ela. Algumas coisas que ela não conseguiria entender. É que ela realmente não sabe muita coisa sobre este mundo.

\section{Perguntas:}

1 Existem diferentes tipos de desigualdade entre os grupos da sociedade (por exemplo, as pessoas podem ter um maior ou menor estatuto com base nos seus grupos étnicos ou raciais, classe económica, sexo, idade ou outras características). Que formas de desigualdade estão presentes nesta relação?

2 Que pessoa tem uma posição de mais poder nesta relação em resultado do seu estatuto na sociedade? Qual é a base desta desigualdade? Como é demonstrada a posição mais poderosa?

3 Que pessoa tem a posição inferior nesta relação por causa do seu estatuto social? De que forma é demonstrada esta posição inferior?

4 Que efeito, se houver algum, esta desigualdade tem em cada pessoa? Como afecta a relação?

5 Acham que este tipo de questões existe na nossa comunidade? Favor comentar. 


\section{FICHA DO GRUPO 4:}

Fui para o estrangeiro para trabalhar durante algum tempo e acabei apaixonando-me por um dos homens que trabalha comigo. Quando engravidei, decidimos casar. Os meus pais estavam contra o casamento porque ele vem de uma família pobre. Disseram-me "Achamos que não sabes quais são as implicações de casar com alguém que não é igual a ti. Porque não voltas para casa e tens o bebé aqui? Nós vamos ajudar-te." Mas nós casámo-nos. Decidimos regressar ao meu país para que ele obtivesse um diploma universitário enquanto eu trabalhava. Mas para poder estudar, tinha que aprender a língua.

Infelizmente, ele achou difícil. Ele estava em casa com o bebê e tentando estudar, mas sentia-se muito isolado. Sentiu-se cada vez mais deprimido e a sua auto-estima baixou imenso. Dependia de mim para ter dinheiro e sentiase culpado porque regularmente tínhamos que enviar dinheiro para a sua família. Eu não gostava nada do facto de ele não estar a estudar, nem a procurar trabalho, mas tinha reservas em relação a dizer-lhe alguma coisa. Era um tema muito sensível e eu não queria magoar os seus sentimentos. Eventualmente, acabou fazendo amizades com alguns homens do seu país e começou a passar tempo com eles, a frequentar bares e a beber. Uma vez até chegou a ser violento comigo. Esse foi um sinal de alerta real para nós.

\section{Perguntas:}

1 Existem diferentes tipos de desigualdade entre os grupos da sociedade (por exemplo, as pessoas podem ter um maior ou menor estatuto com base nos seus grupos étnicos ou raciais, classe económica, sexo, idade ou outras características). Que formas de desigualdade estão presentes nesta relação?

2 Que pessoa tem uma posição de mais poder nesta relação em resultado do seu estatuto na sociedade? Qual é a base desta desigualdade? Como é demonstrada a posição mais poderosa?

3 Que pessoa tem a posição inferior nesta relação por causa do seu estatuto social? De que forma é demonstrada esta posição inferior?

4 Que efeito, se houver algum, esta desigualdade tem em cada pessoa? Como afecta a relação?

5 Acham que este tipo de questões existe na nossa comunidade? Favor comentar. 


\section{é amor?}

VISÃO GERAL: Os alunos distinguem o amor de emoções relacionadas.

OBJECTIVOS: Permitir que os alunos reflictam sobre o amor, fascínio e ciúmes; fortalecer as habilidades de pensamento analítico.

\section{INSTRUÇÕES}

1 Divida os alunos em cinco grupos. Peça a cada um dos grupos que retire um dos pedaços de papel que preparou. No quadro, escreva "Qual é a diferença entre o amor $\mathrm{e}$ ?"

2 Peça aos grupos que tirem um pedaço de papel e copiem a frase no quadro, preenchendo o espaço vazio com a palavra que se encontra no seu pedaço de papel. Peça que discutam a sua pergunta e escrevam a resposta.

3 Depois de cerca de cinco minutos, peça a um grupo para ler a sua pergunta e apresentar a sua resposta. As seguintes perguntas podem orientar uma breve discussão:

- Alguém quer discordar ou comentar?

- A cultura dá às raparigas e rapazes a mesma autorização para viver este sentimento?

- Podem dar um exemplo de quando uma pessoa confunde este sentimento com o amor? O que acontece se este sentimento for confundido com o amor?

- Este sentimento pode fazer parte do amor?
4 Repita a etapa 3 com os restantes quatro grupos.

5 Reserve dez minutos para discutir os seguintes aspectos: impressões sobre o amor e o romance?

- Os filmes e os romances apresentam um retrato realista destes sentimentos? Caso não, que efeitos acham que têm nas expectativas dos jovens?

- Porque é importante que entendam as vossas próprias convicções sobre a diferença entre o amor e estes outros sentimentos?
- Onde é que os jovens desenvolvem as suas

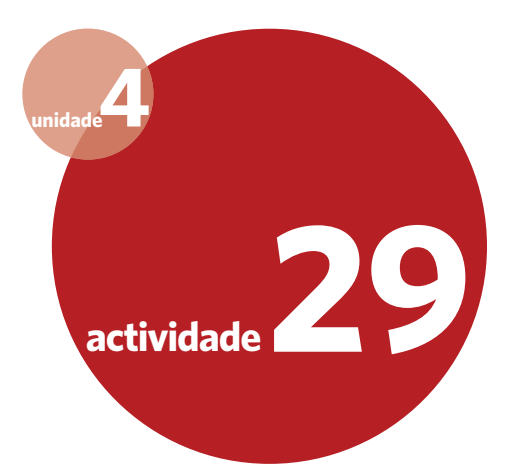

\section{DURAC̣ÃO:}

45 minutos

\section{MATERIAL:}

Quadro + giz; pedaços de papel com frases escritas.

\section{PREPARAC̣ÃO:}

Alterar a actividade conforme for necessário para que se enquadre na cultura, conjuntura e língua dos alunos. Escrever em cinco pedaços de papel uma das seguintes frases em cada um deles:

- FAsCínIO

- ESTAR "APAIXONADO"

- ROMANCE

- atraccĩa sexual

- CIÚMES 


\section{decidir se pratica relações sexuais}

actividade

\section{0}

\section{DURACÃO:}

45 minutos

\section{MATERIAL:}

Quadro + giz; cópias das instruções da ficha "Estou Pronto? Como Devo Decidir?"; ficha técnica do aluno Sentindose 'Pronto' para Ter Relações Sexuais."

\section{PREPARAC̄̃O:}

Rever a lista de condições contida no mapa e certificarse de que se sente preparado para responder a quaisquer perguntas que os alunos possam colocar.
VISÃO GERAL: Os estudantes analisam os indicadores de maturidade, consciência, auto-eficácia e capacidade de comunicar, que fazem parte do que uma pessoa jovem necessita para negociar um relacionamento sexual seguro e confortável. (Nota: Antes desta sessão, os seus alunos devem ter aprendido sobre comportamento sexual e coacção sexual.)

OBJECTIVOS: Ajudar os estudantes a identificar as habilidades de que necessitarão para conseguir negociar um relacionamento sexual seguro e confortável; fortalecer as habilidades de pensamento crítico.

\section{INSTRUC̣ÕES}

1 Apresente a actividade explicando o seguinte:

- As pessoas jovens utilizam critérios diferentes para decidir se e quando se devem tornar sexualmente activos. Alguns esperam até atingirem uma certa idade; outros optam por esperar até estarem noivos ou casados. Outros ainda iniciam a actividade sexual porque uma outra pessoa mais ou menos toma a decisão por eles. Muitas pessoas jovens consideram como se sentem sobre seu relacionamento quando ponderam a decisão de iniciar a actividade sexual.

- É difícil para muitos jovens determinar se estão prontos para a actividade sexual. Este exercício irá ajudar-vos a pensar nos papéis que a maturidade, a consciência e as habilidades de comunicação representam para uma pessoa estar pronta para a actividade sexual. Também vos ajudará a identificar o que é mais importante para vocês.
2 Peça aos alunos que formem pares; distribua uma ficha (com instruçôes) a cada par. Explicar:

- Olhem para a lista contida nesta ficha. Estes são alguns dos sentimentos e condições que de conforto e segurança num relacionamento sexual. Se uma pessoa quiser ter relações sexuais e muitas ou todas estas condições existirem no seu relacionamento, é mais provável que essa pessoa se sinta à vontade e segura com o acto sexual.

- Se muitas destas condições não existirem num relacionamento, é provável que a pessoa não se sinta à vontade e corra um risco maior de ter relações sexuais não seguras. podem ser importantes para se ter uma sensação 
3 Leia em voz alta as instruções para o uso da ficha. Verifique se todos entendem a actividade. Diga-

lhes que vão verificar diferentes itens em resposta a várias perguntas. Devem tentar chegar a acordo sobre as suas respostas, mas se não conseguirem, podem acrescentar outros itens. Dar 15 minutos para os alunos discutirem as perguntas e registarem as respostas

4 Reúna o grupo. Rever as perguntas $1-5$ da ficha e peça algumas respostas. Pergunte se a tendência dos alunos foi de concordar ou discordar dos seus parceiros.

5 Em relação à pergunta 6 da ficha, leve mais tempo a analisar as respostas dos estudantes. Anote as suas respostas no quadro. As seguintes perguntas podem orientar a discussão:

- Que condições os rapazes parecem considerar prioritárias?

- Quais são as mais importantes para as raparigas?

- Como explicam e qual a vossa opinião em relação a quaisquer diferenças nas prioridades dos rapazes e das raparigas'?
6 Encerre com uma discussão das perguntas 7 e 8 da ficha. Em seguida, pergunte:

- Algumas destas condições não são importantes para vocês, que decididamente não considerariam como um factor na decisão sobre se devem, ou não, ter relações sexuais?

- Independentemente de serem sexualmente activos na adolescência ou se decidem esperar até serem adultos ou estarem casados, estabelecer estas condições pode tornar a vossa experiência sexual mais segura e mais confortável. [Informar ao grupo se tem planos de tratar de algumas das outras questões como parte do programa. Por exemplo, o primeiro volume de Um Só Currículo inclui unidades sobre a comunicação, o corpo e a anatomia, a saúde sexual/HIV e questões de género.] 


\section{estou pronto? como devo decidir?}

Para este exercício, um jovem da vossa idade está a tentar decidir se deve iniciar a actividade sexual. Esse jovem quer tomar a decisão certa e faz a pergunta: "Ao decidir se estou pronto para ter relações sexuais, quais são os dois sentimentos ou condições mais importantes que devo tomar em consideração?" Ele faz esta pergunta a três pessoas: o seu melhor amigo, um conselheiro (ou psicólogo) e um doente de SIDA.

\section{Agora sigam estas etapas:}

1 Leiam a lista do vosso mapa.

2 Discutam e decidam como cada uma destas pessoas iria responder a esta pergunta.

3 Melhor amigo: Na caixa ao lado dos dois sentimentos ou condições que acham que o melhor amigo diria que são mais importantes, desenhar um rosto sorridente ((i)).

4 Conselheiro: Na caixa ao lado dos dois sentimentos ou condições que acham que um conselheiro ou psicólogo diria que são mais importantes, assinalar com o símbolo $(\mathcal{})$.

5 Na caixa ao lado dos dois sentimentos ou condições que acham que alguém com SIDA diria que são mais importantes, desenhar uma cópia do símbolo global de Sensibilização sobre o SIDA ( $\mathbf{X}$.

6 Discussão: Acham que algum destes sentimentos ou condições são mais importantes para os rapazes do que para as raparigas? Ao lado de todas as condições que achem que são mais importantes para os rapazes do que para as raparigas, desenhem a figura de um rapaz. Ao lado de todos os sentimentos e condições que achem que são mais importantes para as raparigas, desenhem a figura de uma rapariga.

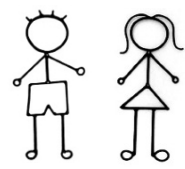

7 Agora pensem nos dois sentimentos ou condições que os jovens mais ignoram ou com que têm dificuldades ao decidir ter relações sexuais pela primeira vez. Na caixa ao lado destes itens, desenhem um "rosto triste" (i)).

8 Existem outros sentimentos ou condições que acham que são importantes e que, portanto, devem ser tomados em consideração antes de praticar relações sexuais pela primeira vez? 


\section{SENTIR-ME "PRONTO" PARA TER RELAÇÕES SEXUAIS}

\begin{tabular}{|c|c|c|c|}
\hline $\begin{array}{l}\text { Um Sentimento ou Condição para } \\
\text { Ter Relações Sexuais }\end{array}$ & Desenhar aqui & $\begin{array}{l}\text { Um Sentimento ou Condição para } \\
\text { Ter Relações Sexuais }\end{array}$ & Desenhar aqui \\
\hline $\begin{array}{l}\text { Sentir que você está a honrar os seus próprios valores } \\
\text { e os do seu parceiro }\end{array}$ & & $\begin{array}{l}\text { Sentir-se à vontade para perguntar o que é bom para ele } \\
\text { ou ela }\end{array}$ & \\
\hline Sentir-se próximo da outra pessoa & & $\begin{array}{l}\text { Sentir-se à vontade para falar com a outra pessoa sobre o } \\
\text { uso do preservativo }\end{array}$ & \\
\hline $\begin{array}{l}\text { Sentir que você e a outra pessoa se respeitam } \\
\text { mutuamente }\end{array}$ & & $\begin{array}{l}\text { Ter preservativos (e/ou outros contraceptivos e saber } \\
\text { usá-los) }\end{array}$ & \\
\hline Sentir que você e a outra pessoa confiam um no outro & & Conhecer o seu estado em relação ao HIV & \\
\hline $\begin{array}{l}\text { Sentir que você e a outra pessoa tomaram a decisão } \\
\text { juntos e que os dois querem ter relações sexuais }\end{array}$ & & $\begin{array}{l}\text { Sentir-se à vontade para falar sobre o seu próprio estado } \\
\text { em relação ao HIV e o do seu parceiro }\end{array}$ & \\
\hline Sentir-se à vontade com o seu próprio corpo & & $\begin{array}{l}\text { Cada um de vós sente-se seguro para dizer a qualquer } \\
\text { altura que quer parar }\end{array}$ & \\
\hline $\begin{array}{l}\text { Sentir-se confiante em relação ao facto de que } \\
\text { sabe o que o/a faz sentir-se bem sexualmente }\end{array}$ & & Ter privacidade & \\
\hline Sentir-se sexualmente atraído/a pela outra pessoa & & $\begin{array}{l}\text { Sentir que não está em risco de ser ridicularizado } \\
\text { ou estigmatizado a seguir }\end{array}$ & \\
\hline $\begin{array}{l}\text { Sentir-se à vontade para dizer à outra pessoa } \\
\text { o que o/a faz sentir-se bem sexualmente }\end{array}$ & & Outro? & \\
\hline
\end{tabular}




\section{como vivemos juntos em relacionamentos}

\section{DURAC̣ÃO:}

45 minutos

\section{MATERIAL:}

Quadro + giz

\section{PREPARAC̣ÃO:}

Rever a lista de práticas abaixo indicadas para se certificar de que todas elas são adequadas para os estudantes discutirem de forma resumida. Certificar-se também de que você está em condições de dar uma definição simples de cada uma delas. Algumas destas práticas podem ser relativamente raras no seu contexto, mas os alunos poderão ter aprendido sobre elas noutras aulas ou em filmes, ou ainda na internet.
VISÃO GERAL: Os alunos analisam se os costumes relacionados com o casamento e a estrutura familiar estão a mudar e como estão a mudar.

OBJECTIVOS: Ajudar os alunos a clarificar as suas próprias expectativas e valores sobre relacionamentos de longa duração; entender que as normas sociais mudam com o tempo; fortalecer as habilidades de pensamento analítico e de escrita.

\section{INSTRUC̣ÕES}

1 Escreva a seguinte lista no quadro:

\section{Casamento infantil}

Relacionamentos ou casamentos entre pessoas do mesmo sexo

Casais que têm relações sexuais ou vivem juntos antes do casamento

\section{Casamento arranjado}

Um homem que bate na sua mulher se ela the desobedecer

Aconselhamento marital

Famílias alargadas que vivem juntas

Homens que se envolvem mais como pais

Homens com várias esposas

Divórcio

Preço da noiva / dote
2 Explique:

- Esta é uma lista de costumes relacionados com o amor e o casamento que são praticados em diferentes culturas. Alguns deles - como o divórcio, o casamento entre pessoas do mesmo sexo ou a idade mínima para o casamento - são questões previstas na lei. Outras práticas tais como famílias alargadas que vivem juntas, casais que vivem juntos antes do casamento ou padrões de paternidade — normalmente estão estabelecidas de uma maneira menos formal. Vocês provavelmente aprovam algumas destas práticas e talvez não aprovem outras.

- Revejam a lista e seleccionem uma prática que acham que mudará na próxima geração. Pode ser uma mudança que considerem que seja para melhor ou para pior. 
3 Peça aos estudantes que abram os cadernos. Digalhes para escreverem pelo menos meia página sobre esta mudança. Faça as seguintes perguntas para estimular o seu pensamento:

- Que prática da lista acham que irá mudar na próxima geração?

- Acham que a mudança ocorrerá na nossa cultura ou num outro local?

- Prevêem uma mudança nas atitudes das pessoas? Uma mudança na forma como a prática é comum? Uma mudança na forma como esta prática ocorre? Que mais?

- Acham que algumas leis que regulam a prática irão mudar?

- Procurem discutir se concordam com as mudanças que esperam ver. Estão a basear os vossos pontos de vista na experiência pessoal ou no que leram ou ouviram?

4 Analise a lista. Em relação a cada prática, peça a um voluntário que tenha escrito sobre essa mesma prática para ler o que escreveu. Em seguida, peça um ou dois comentários breves; varie o tempo que concede para os comentários dependendo de cada tópico ter, ou não, um voluntário.
5 Reserve os últimos cinco minutos para discutir os seguintes aspectos:

- O que acham que faz com que comunidades inteiras, ou até países, mudem as suas perspectivas em relação ao amor e ao casamento?

- Onde é que as pessoas obtêm novas ideias e como é que estas ideias se popularizam? [Sondar o seguinte: Pessoas que fazem escolhas para viverem de maneira diferente; órgãos de informação; intercâmbio intercultural; mudanças na economia que afectam onde os membros da família vivem; movimentos políticos].

- Imaginem que têm um amigo com que se correspondem a viver numa cultura muito diferente. As práticas em que este amigo vive são muito diferentes das nossas. Ao deixarem a sala de aula, pensem no que iriam descrever ao vosso amigo sobre como as pessoas daqui encontram parceiros de longa duração, que entendimentos temos para vivermos juntos e quais são as nossas práticas comuns para começar ou terminar um casamento. 


\section{o que eu procuro}

\section{DURAC̣̃̃O:}

Etapas 1-3: 40 minutos

Paso 4: 5 minutos (este trabalho deve ser dado pelo menos um dia antes das Etapas 5-6)

Etapas 5-6: 40 minutos

\section{MATERIAL:}

Quadro + giz

\section{PREPARAC̄̃O:}

Esta é uma actividade composta por duas partes (Etapas

1-3 e Etapas 4-6); pode ser apresentada apenas uma ou as duas partes. Decidir se va fazer uma ou as duas partes. Se estiver a fazer as Etapas 4-6, procurar concluir a Etapa 4 pelo menos um dia antes das Etapas 5-6.
VISÃO GERAL: Os alunos enumeram as qualidades que procurariam num parceiro de longa data e analisam as suas respostas sob uma perspectiva de género. Os alunos consolidam o que aprenderam numa carta ou canção para um futuro parceiro imaginário.

OBJECTIVOS: Permitir que os alunos identifiquem e reflictam sobre que características mais prezam num parceiro de longa data; clarificar os seus valores e fortalecer as suas habilidades de pensamento abstracto e de escrita criativa.

\section{INSTRUC̣ÕES}

1 Explique:

- Hoje vamos analisar as qualidades ou as características que procuramos num parceiro de longa data ou para toda a vida.

- Peguem nos vossos cadernos e escrevam pelo menos cinco qualidades ou características que consideram importantes num cônjuge ou parceiro de longa data.

- Classifiquem estas características, em que '1' é a mais importante.

2 Peça aos alunos que formem dois grupos, um constituído só por rapazes e outro apenas por raparigas (a menos que a turma seja toda ela constituída por indivíduos só do sexo masculino ou só do feminino). Se tiver muitos alunos, poderá ter que constituir dois grupos de raparigas e dois de rapazes. Explicar:

- Comparem a vossa lista com outras do vosso grupo. Identifiquem que qualidades ou características que no vosso grupo obtiveram mais frequentemente a classificação '1' ou '2' (ou seja, muito importantes). [Poderão constatar que diferentes pessoas usam diferentes palavras para a mesma qualidade, por exemplo generoso / bondoso; divertido / cómico. Circule pela sala e ofereça ajuda se for necessário].

- Peça a uma pessoa de cada grupo para vir ao quadro e escrever as três ou quatro qualidades mais importantes identificadas pelo seu grupo. Registar se a lista é do grupo das raparigas ou dos rapazes.

3 Analise cada lista e dinamize uma discussão com base nas seguintes perguntas:

- O que notam nestas duas listas?

- Quais são as suas semelhanças?

- Quais são as suas diferenças?

- Porque acham que existem diferenças?

- As raparigas têm perguntas a fazer aos rapazes sobre a sua lista?

- Os rapazes têm perguntas para as raparigas?

- Constatam alguns estereótipos de género nas listas? Em caso afirmativo quais? 
4 (Esta etapa deve ocorrer pelo menos um dia antes das Etapas 5-6. Se for possivel, escrever o trabalho no quadro). Explique o trabalho de escrita criativa. Esclareça se deve ser realizado na sala ou em casa.

- Imaginem o tipo de pessoa com quem gostariam de passar o resto das vossas vidas, ou de ter como parceiro de longa data.

- Escrevam uma carta, um poema ou uma canção para essa pessoa imaginária.

- Escrevam sobre o que procuram nessa pessoa e num relacionamento de longa duração. Incluam quais são as vossas expectativas, como gostariam de ser tratados e o que não tolerariam.

- Como alternativa, se acharem que preferem não ter um relacionamento de longa duração na vossa vida, podem escrever ou cantar sobre isso.

- Amanhã (ou numa sessão posterior) terão a oportunidade de ler ou representar o que escreveram.
5 Defina um dia para as representações / recitais em que os estudantes partilham as suas cartas, poemas e canções. Se não tiverem tempo suficiente para todos lerem ou representarem, escolha um dos voluntários. Também poderá pedir aos alunos que entreguem os seus trabalhos para que os leia sem indicar o nome do autor.

6 Reserve dez minutos para uma discussão com base nas seguintes perguntas:

- O que ouviram que vos tocou de forma particular?

- Como é que as diferenças naquilo que os rapazes e as raparigas procuram nos seus parceiros afectam os relacionamentos?

- Como explicam estas diferenças? Ou seja, como é que as pessoas chegam a priorizar certas características?

- Será que todos têm que constituir um relacionamento de longa duração para serem felizes?

- Porque acham que é importante pensar agora sobre o tipo de relacionamento que poderão (ou não) querer? 


\section{problemas de amor}

\section{DURAC̣ÃO:}

Etapas 1-3: 30 minutos

Paso 4-6: 50 minutos

\section{MATERIAL:}

Quadro + giz; quatro histórias sobre relacionamentos (extraídas de "Estudos de Caso sobre Relacionamentos em Problemas"), cada uma escrita numa folha diferente.

\section{PREPARAĈ̣̃O:}

Dos estudos de caso, seleccionar quatro situações de relacionamento que sejam mais adequadas aos seus alunos. Adaptá-las consoante as necessidades e copiar cada uma delas numa folha de papel diferente. Procurar saber onde uma pessoa que pretenda obter conselhos sobre um relacionamento atribulado, ou que esteja a enfrentar o risco de violência num relacionamento, pode procurar ajuda. (Ver a última pergunta da Etapa 6).
VISÃO GERAL: Os alunos concluem histórias sobre relacionamentos que mostrem sinais de problemas e reflectem sobre o que os faria terminar uma relação. (Nota: Antes desta actividade, os alunos devem ter aprendido sobre o direito de estarem livres da violência em relacionamentos íntimos).

OBJECTIVOS: Permitir que os alunos identifiquem estratégias para enfrentarem problemas nos relacionamentos e para terminarem uma relação; identificar comportamentos que não tolerariam numa relação; esclarecer os seus valores sobre a dignidade num relacionamento; incentivar a aprendizagem colectiva e aumentar o conforto ao falar em público.

\section{INSTRUC̣ÕES}

1 Explique:

- Hoje vamos explorar problemas existentes nos relacionamentos.

- Quais são alguns dos problemas que as pessoas normalmente enfrentam nos seus relacionamentos românticos? [Escrever as respostas no quadro. Alguns exemplos: envolvimento da família, comunicação, expectativas ou empenho desiguais, ciúmes e conflitos em relação a dinheiros ou ao poder de decisão].

2 Divida a turma em quatro grupos. Explique:

- Vou dar a cada grupo o início de uma história sobre um relacionamento. Cada grupo deve decidir como concluir a história. Decidam o que este casal deve fazer, tendo em conta o que seria possível.

- Preparem-se para representar o fim da vossa história numa peça teatral com uma duração inferior a cinco minutos. Enquanto trabalham, imaginem e representem a conversa do casal.
- Duas pessoas de cada grupo devem desempenhar o papel dos dois parceiros, e os outros alunos devem dar o seu contributo ou podem representar outros papéis, por exemplo de membros da família.

3 Dê a cada grupo uma situação de um relacionamento e tempo de preparação.

4 Peça a um grupo para representar a sua história. Dê alguns minutos para os alunos discutirem:

- Que problemas ou conflitos tem o casal?

- Como enfrentaram os seus problemas?

- O que acham da maneira como o grupo resolveu a situação? Este resultado é realista?

- Alguém quer sugerir outra opção? 
5 Proceda da mesma maneira com as outras peças teatrais. Cada grupo deve ter cerca de dez minutos (peça teatral mais discussão).

6 Conclua dinamizando a discussão com base nas seguintes perguntas:

- Quais são alguns sinais que podem alertar para a existência de problemas num relacionamento?

- Que circunstâncias podem manter uma pessoa num relacionamento problemático ou violento? (Por exemplo, filhos, necessidade económica, vergonha do divórcio.)

- Por vezes, as pessoas terminam os relacionamentos, incluindo os casamentos. As pessoas tratam os homens divorciados e as mulheres divorciadas da mesma maneira ou diferente da forma como tratam as pessoas casadas? [Se houver diferenças, perguntar: Porque são vistas de maneira diferente? O que acham disso?]

- Que circunstâncias ou comportamentos fariam com que vocês terminassem uma relação?

- Para onde uma pessoa que está em risco de ser vítima de violência num relacionamento se pode dirigir para obter apoio? Para onde uma pessoa pode procurar apoio e aconselhamento sobre um relacionamento problemático? 


\section{estudos de caso sobre relacionamentos problemáticos}

Adey e Beto iniciaram o seu relacionamento na escola secundária e agora frequentam universidades diferentes. Os dois estão de regresso à casa para as férias. Ontem à noite saíram com alguns amigos e Beto fez alguns comentários sobre Adey que feriram os seus sentimentos. Quando ela se mostrou aborrecida, ele disse que estava a brincar. Mais tarde, quando Adey perguntou a Beto sobre uma mulher que ele estava sempre a mencionar, ele admitiu que tinha tido relações sexuais com ela...

Cala e Daoud estão casados há um ano. Muitas vezes têm discussões acaloradas, mas nunca andaram aos socos até há cerca de um mês. Tiveram uma discussão muito grande sobre a família de Cala e Daoud deu-lhe um par de bofetadas. No dia seguinte, pediu-lhe muitas desculpas e trouxe-lhe um presente, prometendo que isso não voltaria a acontecer. Mas ontem à noite aconteceu. Esta manhã, Cala acordou com o olho negro e inchado. . .

Elena e Fritz iniciaram o seu relacionamento há vários anos. Costumavam passar bons momentos juntos — riamse muito, conversavam sobre tudo mais alguma coisa e tinham uma relação física intensa. Agora parece que estão demasiado habituados um ao outro. Praticamente passam o tempo a ver televisão e mal conversam. Até a sua vida sexual tornou-se rotineira e infrequente. Elena pergunta-se "O que aconteceu com o amor que eu sentia?"

Grete e Henri começaram o seu relacionamento há cerca de um ano. Grete tem 18 anos e acaba de começar os seus estudos universitários e Henri tem 25 e trabalha. Grete está realmente animada com a ideia de ir para a universidade e está ansiosa por fazer novas amizades, estudar muito e desfrutar a vida no campus. Henri sente que está pronto para se estabelecer na vida e começar uma família. Acha que gostaria de se casar com Grete. Mencionou recentemente a ideia de casar e ficou chocado com a reacção de Grete. Ela olhou para ele como se estivesse maluco e disse "Acabo de começar os meus estudos. Quero gozar a vida agora e procurar ter sucesso, não casar!” 


\section{estudos de caso sobre relacionamentos problemáticos}

Ivan e Josefa são parceiros há mais de um ano. Os dois trabalham e gostam de sair com os amigos. Ontem à noite foram a um clube. Josefa conversou, riu-se e dançou com as amigas. Ivan dançou com muitas pessoas e teve uma conversa interessante com uma mulher que acabava de conhecer. Achou que ele e Josefa tinham passado uns bons momentos, mas quando foram para casa, Josefa estava zangada. Ela disse "Eu vi a maneira como olhavas para aquela mulher. Não me digas que não estavas interessado nela! E a maneira como vocês dançavam! A tentar chamar a atenção de todos naquele sítio!”

Kiki, uma estudante universitária, trabalha em tempo parcial, mas não ganha muito. Lisa tem um trabalho profissional e aufere um bom salário, pelo que ela paga a maior parte das despesas. Kiki e Lisa combinaram que, quando fosse possível, Kiki faria o rancho ou contribuiria para a renda, mas isto raramente acontece. Quando Kiki compra roupa para ela, tem a tendência de comprar coisas caras. Isto aborrece Lisa, porque ela acha que essa despesa é desnecessária. Há uns dias, Kiki foi remunerada por um trabalho que fez durante as férias e ontem saiu e gastou mais de metade do dinheiro na compra de um computador, sem discutir o assunto com Lisa. Quando ela voltou para casa com o computador, Lisa ficou muito zangada.

Mika e Nobu são casados e têm três filhos de um, três e seis anos. Quando o período menstrual de Mika atrasou, ela foi à clínica e soube que estava grávida de cinco semanas. Quando recebeu a notícia, Mika ficou desesperada. Ela e Nobu mal se aguentam na situação como está e o dinheiro é escasso. Também estava zangada. Suspeitava que engravidara na noite em que Nobu voltou para casa embriagado e não usou o preservativo. Ela disse a Nobu que queria fazer o aborto. Nobu ficou chocado. Ele disse "Sei que é difícil, mas não quero que faças isso. ..." 


\section{eu disse isso? diferentes estilos de comunicação}

\section{DURAC̣ÃO:}

45-60 minutos

\section{MATERIAL:}

Cópias das duas fichas ("Autoavaliação" e "Analisar esta Resposta") para cada estudante, se for possível.

\section{PREPARAC̄̃O:}

Tirar cópias das fichas, se for possível. Caso contrário, preparar-se para ler.
VISÃO GERAL: Os alunos analisam formas alternativas de responder verbalmente numa situação desconfortável e discernem entre comunicação agressiva, assertiva e passiva. Preenchem um questionário sobre o seu próprio estilo de resposta em situações desconfortáveis.

OBJECTIVOS: Aumentar a compreensão dos alunos de diferentes estilos de comunicação e a sua capacidade de formular respostas assertivas; melhorar as suas habilidades analíticas e de diálogo.

\section{INSTRUCÕ̃ES}

1 Apresente a actividade:

- Hoje vamos aprender diferentes estilos de comunicação.

- Em especial quando nos sentimos particularmente desconfortáveis numa situação, podemos não comunicar com clareza e da maneira que pretendemos.

- Quais são algumas das razões que podem fazer com que tenhamos problemas em manifestar da melhor maneira o que queremos? [Sondar as seguintes razões e escrevê-las no quadro]:

Não sei como me expressar com clareza.

Receio que a outra pessoa tenha uma má impressão de mim se eu não concordar.

Receio não ser ouvido, que o que eu digo não seja importante.

Receio perder a paciência.

Acho que é mais fácil se intimidar a outra pessoa.

\begin{abstract}
- Primeiro, vamos olhar para a diferença entre a comunicação agressiva, passiva e assertiva. Em seguida, devem preencher um questionário sobre o vosso próprio estilo de responder numa situação desconfortável.

- Qual acham que é a diferença entre comunicar passivamente e comunicar agressivamente? $\mathrm{O}$ que significa comunicação "assertiva"? [Sondar o seguinte: ser honesto; ser directo; falar sobre os seus sentimentos e necessidades; usar linguagem corporal assertiva; falar para si próprio; comunicar claramente, mas sem agressividade]. O que significa comunicar indirectamente [Sondar o seguinte: não ser totalmente passivo, mas não ser directo].
\end{abstract}


2 Peça aos alunos que formem pares e distribua (ou prepare-se para ler em voz alta) a ficha "Analisar esta Resposta”. Explicar:

- Com o vosso parceiro, leiam a descrição da situação de conflito na coluna da esquerda. Em seguida, leiam as várias respostas na coluna seguinte. Para cada resposta, verifiquem se ela é agressiva, passiva ou assertiva. Em relação ao Conflito 5, produzam uma afirmação de uma situação de conflito e diferentes tipos de respostas.

3 Analise cada conflito e peça aos alunos que dêem as respostas correctas e comentem sobre como se sentem ao ouvir a resposta agressiva em comparação com a assertiva. (Chave de Respostas: As respostas a, f, i e k são agressivas. As respostas c, d e h são passivas. As respostas b, e, g e j são assertivas.)
4 Distribua a ficha sobre "auto-avaliação" e peça aos estudantes que a preencham por si mesmos. (Uma alternativa seria escrever no quadro as afirmações e as respostas possíveis, ler em voz alta e pedir aos alunos que anotem em seus cadernos as próprias respostas.

5 Termine a discussão com as seguintes perguntas:

- O que aprenderam sobre o vosso próprio estilo de comunicação?

- Seria útil aprender como comunicar de forma assertiva? 


\section{auto-avaliação: como comunico quando me sinto desconfortável?}

Quando me encontro numa situação desconfortável com um rapaz, tendo a ser:
$\square$ Passiva
$\square$ Assertiva, respeitosa
$\square$ Agressiva
$\square$ Indirecta ou manipuladora

Quando me encontro numa situação desconfortável com uma rapariga, tendo a ser:
$\square$ Passivo
$\square$ Assertivo, respeitoso
$\square$ Agressivo
$\square$ Indirecto ou manipulador

Quando me encontro numa situação desconfortável com um homem adulto, tendo a ser:
$\square$ Passiva
$\square$ Assertiva, respeitosa
$\square$ Agressiva
$\square$ Indirecta ou manipuladora

Quando me encontro numa situação desconfortável com uma mulher adulta, tendo a ser:
$\square$ Passivo
$\square$ Assertivo, respeitoso
$\square$ Agressivo
$\square$ Indirecto ou manipulador

Quando me encontro numa situação desconfortável com alguém que não considero igual a mim, tendo a ser:
$\square$ Passivo
$\square$ Assertivo, respeitoso
$\square$ Agressivo
$\square$ Indirecto ou manipulador

$\square$ Não posso responder a esta pergunta porque considero a todos iguais a mim.

Para mim, manifestar sentimentos de ira é:

$\square$ Bastante fácil (mas por vezes respondo agressivamente)

$\square$ Bastante fácil (e nunca respondo agressivamente ou com violência)

$\square$ Não é fácil nem difícil

$\square$ Um tanto ou muito difícil

Para mim, manifestar quando me sinto vulnerável ou fraco é:

$\square$ Bastante fácil (mas por vezes respondo agressivamente)

$\square$ Bastante fácil (e nunca respondo agressivamente ou com violência)

$\square$ Não é fácil nem difícil

$\square$ Um tanto ou muito difícil 
ANALISAR ESTA RESPOSTA

\begin{tabular}{|c|c|c|c|c|}
\hline CONFLITO & RESPOSTA & Agressivo & Passivo & Assertivo \\
\hline \multirow{3}{*}{$\begin{array}{l}\text { Um rapaz e uma rapariga vão ter } \\
\text { relações sexuais pela primeira vez, } \\
\text { mas não têm preservativos. } \\
\text { Um deles diz: }\end{array}$} & a. Que eu saiba, tens HIV! És um idiota e estúpido. & & & \\
\hline & $\begin{array}{l}\text { b. Também quero fazer sexo, mas só se usarmos o preservativo. } \\
\text { Sei onde os podemos arranjar. }\end{array}$ & & & \\
\hline & c. Oh. Está bem, acho que sim. & & & \\
\hline \multirow{3}{*}{$\begin{array}{l}2 \text { Um rapaz está aborrecido porque a } \\
\text { rapariga com que ele foi à festa estava } \\
\text { a conversar com um outro rapaz. Ele diz: }\end{array}$} & d. Foi uma festa aborrecida, chata. & & & \\
\hline & $\begin{array}{l}\text { Q. Quando estavas a falar com esse fulano, pensei que quisesses } \\
\text { ficar com ele, e não comigo. Isso faz-me sentir mal. }\end{array}$ & & & \\
\hline & $\begin{array}{l}\text { f. Eu vi! Como te atreves a falar com aquele fulano quando vieste } \\
\text { para a festa comigo? }\end{array}$ & & & \\
\hline \multirow{3}{*}{$\begin{array}{l}3 \text { Um rapaz pede a uma rapariga para sair } \\
\text { com ele. Ela não quer. Ela diz: }\end{array}$} & g. Obrigada, mas não quero. Desculpa. & & & \\
\hline & h. Hum... Está bem. & & & \\
\hline & i. Nunca sairia com uma pessoa como tu. Deixa-me em paz. & & & \\
\hline \multirow{2}{*}{$\begin{array}{l}4 \text { Uma rapariga está aborrecida porque } \\
\text { a sua amiga Lulu tem estado a fazer } \\
\text { troça dela com Amina. Ela diz: }\end{array}$} & j. Lulu, estou aborrecida contigo por estares a fazer troça de mim. & & & \\
\hline & $\begin{array}{l}\text { k. És a pessoa mais estúpida do mundo e eu vou contar a todos as } \\
\text { tuas histórias. }\end{array}$ & & & \\
\hline \multirow{3}{*}{$\begin{array}{l}5 \text { Pensem numa outra situação de conflito. } \\
\text { Escrevam aqui e em seguida escrevam } \\
\text { três respostas na coluna da direita. }\end{array}$} & & X & & \\
\hline & & & X & \\
\hline & & & & X \\
\hline
\end{tabular}




\section{escuta activa}

VISÃO GERAL: Os estudantes praticam comportamentos que melhoram (ou prejudicam) a comunicação.

OBJECTIVOS: Permitir que os estudantes adoptem comportamentos destinados a melhorar a comunicação.

\section{DURAC̣̃̃O:}

50-60 minutos

\section{MATERIAL:}

Quadro + giz; fichas com sugestões

\section{PREPARAC̣ÃO:}

Analisar a informação sobre a comunicação na Unidade 5 do livro de DIRECTRIZES (ou no seu próprio currículo). Analisar a lista de comportamentos específicos na Etapa 6 e alterar se os comportamentos aceitáveis forem diferentes na sua cultura

(por exemplo, o contacto visual não é considerado correcto em alguns contextos; abanar a cabeça de um lado para outro pode ter significados diferentes). Identificar um par (ou dois) de voluntários que possam ser eficazes na representação da situação e preparar cartões com sugestões (ver amostra). O ideal seria preparar os voluntários no dia anterior para que possam ensaiar. Atenção às suas próprias habilidades de escuta especialmente durante esta aula!

\section{INSTRUC̣ÕES}

1 Distribua pelos voluntários que vão representar uma sugestão para cada script. Se for necessário, dê-lhes alguns minutos para preparar ou ensaiar enquanto você apresenta a Etapa 2.

2 Apresente o tema ao resto da turma dando a seguinte explicação:

- Nós dizemos que a comunicação é um processo recíproco. Quando uma pessoa está a falar, o que é que a outra pessoa está a fazer? [Ouvir / escutar]. Então a escuta faz parte da comunicação? [Sim]. Hoje vamos explorar o que comunicamos quando estamos a escutar. Vamos aprender a grande diferença que a "escuta activa" faz na comunicação entre as pessoas.

- Vamos começar por uma demonstração. Peguem nos vossos cadernos. Observem o ouvinte e anotem cada comportamento que acham que interfere na comunicação eficaz.

3 Peça que os voluntários representem o escenario sobre a comunicação "negativa" (script \#1).
4 Reflictam sobre o escenario perguntando:

- Como avaliariam esta conversa? Foi satisfatória e eficaz?

- Que comportamentos verbais e não-verbais foram apresentados pelo "ouvinte"? [No quadro, escrever cada comportamento negativo que os estudantes tiverem mencionado. Sondar o seguinte]:

\section{Comportamentos não-verbais: \\ Franzir a testa}

Demonstrar falta de consideração, revirar os olhos para o céu

Abanar a cabeça como se estivesse a dizer "não" Olhar para o lado ou afastar-se, mostrar-se enfastiado ou desinteressado, Bocejar

\section{Comportamentos Verbais:}

Interromper a pessoa que está a falar, mostrar impaciência, indicar que o falante está a levar demasiado tempo

Expressar opiniões negativas sobre o falante, tais como "está errado" ou "isso é um disparate"

- Pergunte ao "falante" como se sentiu ao não ser ouvido. 
5 Peça a voluntários que representem o escenario sobre a comunicação "positiva" (script \#2).

6 Reflictam sobre o escenario perguntando:

- Como avaliariam esta conversa? Foi mais satisfatória?

- Que comportamentos verbais e nãoverbais tornaram essa conversa mais eficaz do que a anterior? [No quadro, escrever cada comportamento positivo que os alunos mencionarem. Sondar o seguinte]:

\section{Comportamentos não-verbais:}

Manter o contacto visual

Acenar com a cabeça (como a dizer "sim")

Inclinar-se um pouco em direç̧ão ao falante para mostrar que está a ouvir

Oferecer um sorriso ou uma palmadinha nas costas

\section{Comportamentos verbais:}

Pedir esclarecimento para se certificar de que entende o falante

Mostrar interesse em ouvir mais (por exemplo, "Diga-me mais sobre... ")

Validar os sentimentos do falante (por exemplo, "Posso imaginar como se sente.")

Validar as ideias do falante (por exemplo, " $E$ interessante.")

Evitar fazer quaisquer afirmações que façam com que o falante sinta que está a ser considerado inconveniente

Agradecer o falante por confiar em si para partilhar o que lhe vai na mente.
7 Pedir aos estudantes que formem grupos de três para a prática da escuta activa. Explicar:

- Em cada grupo, uma pessoa deve falar durante dois minutos. Quando for a vossa vez de falar, devem falar sobre alguma coisa que vos preocupa ou aborrece. Para efeitos deste exercício, seleccionem um tema que não seja confidencial e sobre o qual possam falar à vontade com os vossos colegas. Poderão sentir-se esperançosos, zangados, preocupados, magoados ou ansiosos. Se não conseguem pensar em algo para falar, pratiquem pedindo à pessoa para votar em vós para se tornarem chefes do vosso conselho da juventude.

- A segunda pessoa deve praticar a escuta activa e a terceira deve observar e fazer comentários (dar feedback). Essencialmente, deverão dar feedback ao ouvinte, mas também podem dar feedback ao falante. Passados dois minutos, devem trocar os papéis. Depois teremos uma terceira ronda. Desta forma, cada um de vocês tem a sua vez para representar cada papel.

8 Inicie a 1a Ronda:

- Falantes, comecem a dizer ao ouvinte algo que vos preocupa na vossa vida.

- [Passados 2 minutos]: Parem. Observadores, dêem 60 segundos de feedback. 
9 Depois de um minuto: Inicie a 2a Ronda:

- Falantes, vocês passam a ser ouvintes. Ouvintes, passem a representar o papel de observadores. Observadores, vocês serão falantes.

- [Passados 2 minutos]: Parem. Observadores, dêem um minuto de feedback.

10 Depois de um minuto: Inicie a $3^{\text {a }}$ Ronda. Enquanto os estudantes concluem esta ronda, poderá escrever a seguinte frase do médico-escritor Karl Menninger no quadro, apenas para inspirar o seu pensamento: "Ouvir é uma coisa magnética e estranha, uma força criativa. Os amigos que nos escutam são para quem nos dirigimos. Quando somos ouvidos, isso cria-nos, faz com que nos revelemos e cresçamos."

- Troquem os personagens mais uma vez e recomecem.

- [Passados 2 minutos]: Parem. Observadores, dêem feedback.

11 Reserve dez minutos para a discussão, com base em qualquer das seguintes perguntas:

- Como se sentem quando vocês são os falantes e a pessoa não está a ouvir devidamente?

- O que acontece quando as duas pessoas têm um conflito real e ambas estão aborrecidas? É mais difícil ou é mais fácil comunicar bem?

- Alguns pesquisadores observaram que as pessoas do sexo masculino e as do feminino têm diferentes estilos de comunicação. $\mathrm{O}$ que se ensina às raparigas e às mulheres sobre como se devem expressar quando estão aborrecidas?

- O que se ensina aos rapazes e aos homens sobre como se devem expressar quando estão aborrecidos? As pessoas podem aprender a comunicar de uma forma que não seja violenta ou agressiva?

- Como acham que a agressão ou a violência afecta a comunicação entre adolescentes do sexo masculino e do feminino num relacionamento íntimo?

- O que as pessoas podem fazer para melhorar a comunicação entre indivíduos do sexo masculino e do feminino, especialmente quando têm um conflito?

- Quantos de vocês conseguiram dar um feedback construtivo quando eram observadores?

- [Se o tempo permitir]: O que pensam sobre a citação na parede? Comentários?

- Pensem numa coisa que gostariam de melhorar no vosso estilo de comunicação. Pratiquem esse comportamento esta noite e durante a semana com os outros. Reparem também como as pessoas escutam quando vocês estão a tentar expressar-se. 


\section{sugestão para o script "o mau ouvinte" (\#1):}

\section{Um de vocês será o "falante" e um será o "ouvinte."}

FALANTE: Elabore um script com base numa situação imaginária. Seleccione: (1) algo que (está a fingir) aconteceu consigo e que acha que foi injusto; ou (2) uma ideia ou plano ousado que (está a fingir) o deixa animado. Para o escenario, você pretende expressar a sua experiência ou ideias e os sentimentos que tem de uma forma muito clara. Deve passar vários minutos a tentar falar com o seu parceiro sobre isso, tentando ser ouvido. Deverá falar durante dois a três minutos.

Responda de acordo com a maneira como o seu parceiro está a ouvi-lo. Se achar que esse parceiro não está a ouvilo, mostre a sua frustração, eleve a voz ou responda de uma forma que possa parecer natural numa situação desta natureza. Se a outra pessoa estiver a ouvir atentamente e com respeito, o comportamento deve ser em conformidade com a situação.

OUVINTE: Você é um MAU OUVINTE. Quando o falante tenta falar consigo, demonstre más habilidades de escuta. A sua tarefa é usar o máximo de comportamentos negativos verbais e não-verbais que puder da lista a seguir:

\section{Comportamentos não-verbais:}

- Franzir a testa

- Demonstrar falta de consideração, revirar os olhos para o céu

- Abanar a cabeça como se estivesse a dizer "não"

- Mostrar impaciência - olhar para o lado ou afastar-se, mostrar-se enfastiado ou desinteressado, bocejar

\section{Comportamentos verbais:}

- Interromper a pessoa que está a falar, começar a falar sobre si próprio ou mudar de assunto

- Expressar opiniões negativas sobre o falante (tais como “Errado!” ou "Isso é um disparate.") 


\section{sugestão para o script "o bom ouvinte" (\#2):}

Um de vocês será o "falante" e um será o "ouvinte."

FALANTE: (As instruções são as mesmas que as da sátira \#1): Elabore um script com base numa situação imaginária. Seleccione: (1) algo que (está a fingir) aconteceu consigo e que acha que foi injusto; ou (2) uma ideia ou plano ousado que (está a fingir) o deixa animado. Para o escenario, você pretende expressar a sua experiência ou ideias e os sentimentos que tem de uma forma muito clara. Deve passar vários minutos a tentar falar com o seu parceiro sobre isso, tentando ser ouvido. Deverá falar durante dois a três minutos.

Responda de acordo com a maneira como o seu parceiro está a ouvi-lo. Se achar que esse parceiro não está a ouvilo, mostre a sua frustração, eleve a voz ou responda de uma forma que possa parecer natural numa situação desta natureza. Se a outra pessoa estiver a ouvir atentamente e com respeito, o comportamento deve ser em conformidade com a situação.

OUVINTE: Você é um OUVINTE ACTIVO. Quando o falante tenta falar consigo, demonstre habilidades de escuta activa. A sua tarefa é usar o máximo de comportamentos positivos verbais e não-verbais que puder da lista a seguir:

Comportamentos não-verbais:

- Manter o contacto visual

- Acenar com a cabeça (como a dizer "sim")

- Inclinar-se um pouco em direcção ao falante para mostrar que está a escutar.

- Oferecer um sorriso ou uma palmadinha nas costas

Comportamentos verbais:

- Pedir esclarecimento para se certificar de que entende o falante

- Mostrar interesse em ouvir mais (por exemplo, "Diga-me mais sobre...")

- Validar os sentimentos do falante (por exemplo, "Posso imaginar como se sente.")

- Validar as ideias do falante (por exemplo, "É interessante.")

- Evitar fazer quaisquer afirmações que façam com que o falante sinta que está a ser considerado inconveniente

- Agradecer o falante por confiar em si para partilhar o que lhe vai na mente. 


\section{praticando a comunicação assertiva}

VISÃO GERAL: Os estudantes analisam os comportamentos assertivos, discutem as implicações culturais e praticam a utilização da comunicação assertiva em situações em que os direitos estejam a ser violados.

OBJECTIVOS: Permitir que os estudantes comuniquem de maneira mais assertiva sempre que necessitarem; fortalecer as suas habilidades de diálogo.

\section{INSTRUÇÕES}

1 Comece por estas perguntas orientadoras:

- Vamos aprender mais sobre a comunicação assertiva. Por vezes é difícil dizer claramente o que querem (por exemplo, que querem ser considerados para um papel de liderança na escola). Também pode ser difícil dizer o que não querem (por exemplo, que não querem comer o que alguém preparou para vocês).

- Quem se pode lembrar de um momento em que não tinha a certeza de como manifestar os seus desejos ou vontades com clareza? [Reparar se as raparigas e os rapazes respondem a esta pergunta].

- Falar com franqueza pode ser difícil, mesmo quando a situação é realmente importante para nós, ou quando podem estar em causa consequências físicas ou emocionais reais. É útil praticar uma comunicação respeitosa, mas assertiva.

- Peguem nos vossos cadernos. Vou passar a ler uma série de perguntas ou afirmações que são "estímulos." Para cada um desses estímulos, escrevam uma resposta que seja assertiva, mas não agressiva. Usem frases completas.

- O primeiro estímulo é o seguinte: "Diga-me por que razão devo votar em si para chefe da turma.”
- Quem pode dar uma resposta assertiva?[Ajudar os estudantes a chegar à resposta certa, por exemplo: "Acredito que sou o candidato mais qualificado para chefe de turma. Espero poder contar com o seu apoio." As respostas devem ser frases completas].

2 Repita o processo para cada estímulo (ver a lista).

3 Encerre com a discussão das seguintes questões:

- Algumas pessoas podem pensar que ser assertivo vai contra a sua cultura ou é indelicado. Qual é a situação em que uma pessoa deve ser assertiva, mesmo que essa resposta seja considerada indelicada? [Sondar o seguinte: quando sentimos que os nossos direitos estão a ser violados].

- As raparigas que são assertivas são tratadas da mesma maneira que os rapazes que são assertivos? Uma pessoa que seja assertiva é vista de maneira diferente se essa pessoa pertencer a um grupo étnico ou racial minoritário? Como é que estes preconceitos podem limitar a capacidade das pessoas se defenderem?

Trabalho de Casa: Praticar ser mais assertivo pelo menos uma vez nos próximos dois dias. Escrever o que acontece e como se sentem.

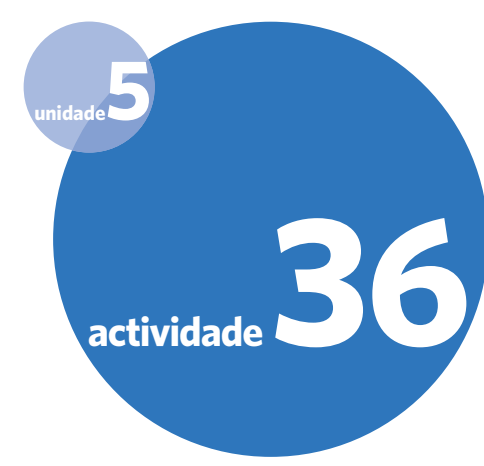

DURAC̣ÃO:

30-40 minutos

\section{MATERIAL:}

A sua cópia da lista de estímulos e exemplos de respostas

\section{PREPARAC̣ÃO:}

Voltar a ler as estímulos e exemplos de respostas; poderá alterar algumas delas para que estejam mais adequadas do ponto de vista cultural. 


\section{lista de estímulos e exemplos de respostas assertivas}

Utilizar as seguintes afirmações para obter respostas assertivas. A seguir estão incluídos exemplos de respostas, caso os estudantes tenham dificuldades em chegar à resposta certa.

1 Estímulo: "Deixas-me copiar o teu teste? O professor não vai saber." Exemplo de Resposta: "Desculpa, mas não acredito em deixar copiar respostas de testes."

2 Estímulo: Você vê o seu supervisor do trabalho e quer pedir-Ihe um aumento. Exemplo de Resposta: "Supervisor, preciso de falar consigo sobre o aumento que acho que mereço."

3 Estímulo: Diga ao seu pai que pretende continuar na escola no próximo ano, apesar das pretensões dele. Exemplo de Resposta: "Pai, eu respeito a sua opinião, mas para mim é extremamente importante continuar a estudar. Gostaria de discutir os meus motivos consigo."

4 Estímulo: "Porque não gostas de desporto como qualquer outra pessoa? O que se passa contigo?" Exemplo de Resposta: "As pessoas são diferentes. Eu gosto mais de ler e de música."

5 Estímulo: "Vem ficar connosco atrás da antiga fábrica; a polícia nunca vai para lá." Exemplo de Resposta: "Não, obrigado. Não estou interessado."

6 Estímulo: "Eu sou o Presidente do Município. Soube que estão a pedir autorização para usar um dos edifícios da cidade para as reuniões do vosso clube depois das aulas."

Exemplo de Resposta: "Sim, Sr. Presidente do Município. Nós somos responsáveis e vamos utilizar o espaço correctamente. Gostaria de ter mais informação sobre os nossos planos?"

7 Estímulo: "Se conseguir convencer os dois colegas ao seu lado a trabalharem consigo no mural, vamos deixá-lo pintar a parede." (Resposta aos colegas de turma).

Exemplo de Resposta: "Temos autorização para pintar um mural se mais dois alunos se juntarem a mim. Gostariam de o fazer?"

8 Estímulo: "Vamos fazer uma visita de campo. Para onde acha que devemos ir?"

Exemplo de Resposta: "Gostaria de ir para e acho que seria interessante também para os outros."

9 Estímulo: "Aquele miúdo novo da outra turma vem para este lado. Vamos pregar-Ihe uma rasteira." Exemplo de Resposta: "Deixa-o em paz. Não nos fez mal nenhum."

10 Estímulo: Agora pensem na situação de que se lembraram no início desta actividade, quando vos foi perguntado sobre o momento em que queriam ter manifestado os vossos desejos de uma forma mais directa. Escrevam o que poderiam ter dito nessa situação. Não terão que partilhar esta resposta. 


\section{cinco etapas para comunicar sobre um conflito}

VISÃO GERAL: Os alunos aprendem e praticam um modelo de cinco etapas para comunicar um conflito interpessoal com clareza e respeito. (Nota: Esta actividade destina-se ao desenvolvimento de habilidades de comunicação mais avançadas.)

OBJECTIVOS: Ajudar os alunos a desenvolver as suas habilidades na comunicação de um conflito num relacionamento íntimo; fortalecer as habilidades analíticas e de diálogo.

\section{INSTRUÇÕES}

1 Explique:

- Hoje vamos aprender e praticar técnicas para comunicar sobre um conflito. Vamos analisar uma situação juntos. Em seguida, vamos formar pares e todos terão a ocasião de praticar.

- Aqui está uma situação imaginária que vamos praticar todos em conjunto: Ron acha que Kirin tem estado a fazer troça dele com outros amigos. Ron está muito aborrecido. Ele vai confrontar Kirin.

2 No quadro, escreva o primeiro estímulo (“QUANDO TU .") e discutam o seguinte:

- Pensem no comportamento específico que está a aborrecer Ron. Em vez de fazerem uma acusação generalizada como "Tu és um mau amigo ...," falem sobre o comportamento específico que esteve na origem do aborrecimento neste caso. [Sondar: "Quando fizeste troça de mim ..." ou "Quando ouvi que fizeste troça de mim ...”. No quadro, escrever o resto do estímulo com o comportamento, usando as palavras sugeridas pelo grupo.]

- Porque é importante comunicar especificamente o comportamento que provocou o aborrecimento?
- Tambem é importante reconhecer se não tiverem a certeza de que a vossa percepção do comportamento é exacta. Por exemplo, poderão dizer "Talvez eu esteja errado, mas ouvi dizer que estavas a fazer troça de mim perante outras pessoas." Porque seria importante criar a possibilidade de ajustar o vosso entendimento sobre o que aconteceu?

3 Escreva o segundo estímulo: "IMAGINO QUE ." e discutam o seguinte:

- Muitas pessoas saltam esta etapa, mas é extremamente importante. Exige que reflictamos sobre as nossas respostas e reacções.

- O que poderá (Ron) imaginar ou começar a pensar? "Quando fizeste troça de mim perante outras pessoas, imagino que (começo a pensar) ..." não te preocupas com os meus sentimentos. Ou: já deves ter falado de mim às outras pessoas antes. $\mathrm{Ou}$ :

não deves sentir-te tão bem contigo próprio. Ou: todos estão a rir-se de mim.

Outras respostas?

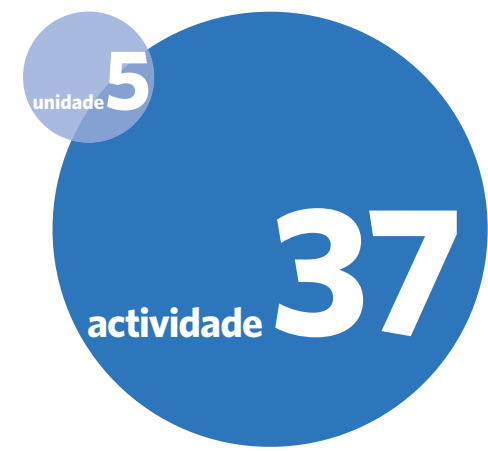

DURAC̣ÃO:

45-60 minutos, dependendo da facilidade de entendimento dos conceitos por parte dos alunos

\section{MATERIAL:}

Quadro + giz

\section{PREPARAC̣̃̃O:}

Familiarizar-se com as 5 etapas para resolver conflitos, pensando em como as mesmas poderiam ser aplicadas a uma situação na sua própria vida. Poderá mudar o exemplo de conflito para uma situação diferente que seja mais adequada ao seu grupo. Neste caso, procurar um exemplo simples e pensar em como apresentar cada etapa com esse exemplo. No início, pode ser um pouco complicado para os alunos usar estas etapas, mas os exemplos simples e a prática tornarão a actividade mais simples. (Até mesmo as crianças mais jovens podem ser orientadas para seguirem estas etapas, mas se achar que a actividade é demasiado extensa, ela poderá ser adaptada de modo a centrar-se apenas nas Etapas 2 e 4.) 
[Reconhecer que várias respostas podem estar certas e preencher um dos exemplos dos alunos para concluir o segundo estímulo].

- Dizer "Imagino (ou receio) que não te preocupes com os meus sentimentos" é diferente de dizer "Tu não te preocupas com os meus sentimentos?

4 Peça a um estudante para ler os primeiros dois estímulos, incluindo as palavras que foram preenchidas. Em seguida, escreva o terceiro estímulo: "E ISSO FAZ COM QUE ME SINTA Discutir o seguinte:

- Prestem atenção exactamente a que emoção Ron poderá estar a sentir. Isto não é o que ele pensa; é o que ele sente.

- Quais são alguns sentimentos que poderão ter se acharem que o vosso amigo tem estado a fazer troça de vocês com outras pessoas? [Sondar o seguinte: Magoado, traído, zangado, embaraçado, só, humilhado].

[Completar o terceiro estímulo escrevendo no quadro duas ou três das palavras sugeridas que descrevem os sentimentos]

5 Peça a um estudante que leia toda a comunicação que escreveu até agora no quadro. Escreva o quarto estímulo: “E ISSO FAZ COM QUE EU TENHA VONTADE DE ." Discutam o seguinte:

- Quais são algumas das coisas que Ron poderá querer fazer: [Sondar quaisquer respostas viáveis, tais como "Tenho vontade de: dizer às pessoas coisas más sobre ti; gritar;

deixar de ser teu amigo; ou

ficar em casa e não ver ninguém."]

[Completar o quarto estímulo por escrito com uma ou duas das respostas dadas. Lembrar aos estudantes que o que podemos querer fazer num determinado momento muitas vezes não é o mesmo que planificamos fazer].

6 Peça a um estudante que leia toda a comunicação escrita no quadro e em seguida escreva o estímulo final:

“MAS EU AINDA ___. Discutam o seguinte:

- Em algumas situações, uma pessoa pode sentirse tão violada que nunca mais queira voltar a comunicar com a outra pessoa. Mas muitas vezes, o falante ainda quer manter o relacionamento com a outra pessoa. Como é que o "ouvinte" se sente depois de ouvir tudo isto?

- Como é que Ron pode tranquilizar de uma forma simples e directa em relação a como se sente no geral? [Sondar respostas como: "Eu ainda...

me preocupo contigo"; ou quero ser teu amigo."]

[No quadro, preencher uma resposta adequada para o último estímulo].

7 Leia toda a comunicação. Peça que os alunos façam comentários. 
8 Peça aos alunos que formem pares e em seguida explique:

- Agora terão a oportunidade de praticar sozinhos estas etapas. Pensem num conflito que acham que não resolveram correctamente. [Se ninguém conseguir apresentar uma situação que possa ser usada, sugerir uma das seguintes:

O seu pai fica muito doente e o seu melhor amigo não manifesta muita simpatia.

O seu primo contou aos amigos a verdade sobre o seu pai, isto é, que ele está na prisão.

O seu amigo nunca lhe empresta o livro escolar, embora você tenha perdido o seu e não tenha condições para o substituir.

O seu amigo está sempre atrasado quando vocês devem fazer alguma coisa juntos.

A sua namorada passou a maior parte do tempo a conversar com um outro rapaz na festa.

O seu namorado disse que se você realmente o amasse, teria relações sexuais com ele.

As suas amigas estão a pressioná-la a "perder a sua virgindade."

A sua namorada fica aborrecida quando você quer usar o preservativo].

- A primeira pessoa diz ao seu parceiro que conflito vão resolver.

- Utilizem as cinco etapas para resolver o conflito. Têm cinco minutos para analisar todas as etapas, uma de cada vez. Não se preocupem se, no início, se sentirem pouco à vontade. Vejam como se sentem no fim.
- Quando você for o ouvinte, ajude o seu parceiro a lembrar-se o que foi discutido sobre cada etapa.

9 Reveja as cinco etapas até se certificar de que os alunos podem referir-se a elas com facilidade:

Quando tu (comportamento específico)

Imagino (ou começo a pensar) que

$E$ isso faz com que me sinta (uma palavra de emoção)

E tenho vontade de

Mas eu ainda ______ de ti.

10 Controle o tempo de modo a que cada parceiro tenha cinco minutos.

11 Incentive a discussão em grupo:

- Conseguiram expressar-se de maneira diferente desta vez em comparação com o momento em que enfrentaram tal conflito pela primeira vez?

- Estas palavras ajudam-vos a expressar os vossos sentimentos reais?

- Qual a sensação de identificar e declarar os vossos sentimentos?

- Lembrem-se que têm o direito de ser tratados com respeito. Quando sentem que não estão a ser tratados com respeito, devem dizê-lo. Se não disserem, quem o fará? 


\section{falar sobre o sexo e a saúde sexual}

\section{DURACÃO:}

Etapas 1-4: 40 minutos

Etapas 5-6: 30 minutos

\section{MATERIAL:}

Quadro + giz; fita-cola e marcadores; cartaz ou folhas de papel grandes; trabalho de preparação e dos grupos dos cartazes.

\section{PREPARACÃO:}

Rever o trabalho das apresentação e dos cartazes e fazer as alterações necessárias para que estejam adequadas ao seu contexto. Se pretender dividir esta actividade em duas sessões, decidir onde interromper a primeira sessão. Escrever cada script e o texto dos cartazes num pedaço de papel diferente para distribuir durante a sessão. Pensar em como poderá aumentar o drama nas apresentações interrompendo após a primeira versão, por exemplo, bater as mãos e depois dizer "tentem de novo!"
VISÃO GERAL: Através da discussão e da representação, os alunos praticam habilidades verbais e não-verbais que são necessárias para comunicar sobre o comportamento sexual, decisões e questões de saúde.

OBJECTIVOS: Fortalecer as habilidades verbais e não-verbais necessárias para comunicar sobre decisões sexuais e questões de saúde; fortalecer habilidades analíticas e de diálogo.

\section{INSTRUÇÕES}

1 Apresente a actividade perguntando:

- Os jovens poderão falar sobre o sexo com os amigos e os órgãos de informação podem referirse ao sexo. Mas é fácil ou difícil para a maior parte dos jovens falar sobre o sexo com o seu próprio namorado ou namorada?

- É fácil ou difícil responder a uma pessoa que está fazendo avanços sexuais?

- Quais são algumas das razões que seja importante conseguir comunicar com a pessoa envolvida sobre questões ligadas ao comportamento sexual e à saúde sexual? [Sondar o seguinte: Deixar claro se a pessoa quer, ou não, ter contacto sexual; com que tipo de contacto se sente à vontade e o que deixa a outra pessoa à vontade; proteger contra as ITS (incluindo o HIV); esclarecer intenções relacionadas com a gravidez; e proteger contra a gravidez indesejada].
- Vamo-nos dividir em pares e em pequenos grupos. Oito alunos (em quatro pares) preparam apresentações de um minuto para praticar como lidar com estas questões em diferentes tipos de situações, usando a comunicação assertiva. Os restantes alunos devem formar quatro grupos pequenos e devem fazer e apresentar cartazes; cada cartaz deve apresentar três maneiras de iniciar um tipo específico de conversa difícil.

2 Constitua os pares e pequenos grupos e distribua as tarefas de preparação de apresentações e de cartazes.

3 Peça a cada par que represente a sua apresentação de um minuto. Em cada par, assim que a Pessoa A "ceder" primeiro, diga "PAREM! TENTEM DE NOVO!” Esta é a deixa para os actores representarem a segunda versão (assertiva) da sua sátira. 
4 No fim das quatro apresentações, incentive uma discussão. Pergunte aos alunos:

- Que versão (passiva ou assertiva) acham que é mais comum?

- O que viram que foi útil?

- Que outras sugestões têm para lidar com esta conversa?

- Onde é que esta conversa poderia levar?

5 Peça a cada grupo que trabalhou nos cartazes para apresentar o seu cartaz. Peça a cada pessoa do grupo para apresentar o cartaz e uma segunda pessoa para anotar as perguntas e peça comentários e sugestões. (Poderá deixar os cartazes na parede durante mais alguns dias.)

6 Encerre a actividade com os seguintes pontos de discussão:

- Vimos que falar por si próprios numa situação sexual pode ser mais difícil se a outra pessoa tiver um estatuto mais elevado ou mais poder. Lembrem-se que têm sempre o direito de consentir ou recusar o consentimento numa situação sexual.
- Como podemos preparar ou ensaiar a maneira de iniciar uma conversa difícil relacionada com a sexualidade? [Sondar o seguinte: Ensaiar em frente ao espelho; escrever com antecedência o que se pretende dizer].

Trabalho de Casa: Pensem numa conversa (sobre qualquer coisa) que tiveram dificuldade de iniciar. Escrevam um script para iniciar essa conversa. Lembrem-se que alguém pode ler e pensar erradamente que realmente tiveram essa conversa. Então, se tiverem quaisquer preocupações acerca da confidencialidade, devem destruir o script depois de acabarem de escrever. Mas primeiro concluam vós próprios esta tarefa; provavelmente sentir-se-ão melhores depois de escrever. 


\section{tarefas de preparação de apresentações}

\section{PAR 1 (PAR MASCULINO/FEMININO):}

Mostre uma conversa de um minuto sobre a prevenção de infecções transmitidas sexualmente. A Pessoa A levanta a questão. A Pessoa B, que é mais velha, não está a colaborar. Poderão decidir qual personagem é do sexo masculino e qual é do sexo feminino. Devem representar a cena duas vezes. Na primeira representação, mostrem a Pessoa A a ceder e a aceitar não usar o preservativo. Depois de o professor interromper, parem a representação e voltem a representar uma segunda vez mostrando como a Pessoa A pode insistir no assunto.

\section{PAR 2 (PAR MASCULINO/FEMININO):}

A Pessoa A inicia uma conversa sobre a prevenção da gravidez. A Pessoa B quer ter um filho e está a resistir à ideia de contracepção. Poderão decidir que personagem é do sexo masculino e qual é do sexo feminino. Devem representar a cena duas vezes. Na primeira representação, mostrem a Pessoa A a ceder e a aceitar não usar contraceptivos. Depois de o professor interromper, parem a representação e voltem a representar uma segunda vez mostrando como a Pessoa A pode insistir no assunto.

\section{PAR 3 (PAR MASCULINO/FEMININO):}

A Pessoa A e a Pessoa B são colegas de turma; poderão decidir que personagem é do sexo masculino e qual é do sexo feminino. A Pessoa A repetidamente abraça a Pessoa B ao caminharem para a escola juntos. A Pessoa B não gosta disso. Devem representar a cena duas vezes. Na primeira representação, a Pessoa B não está feliz, mas não responde. Depois de o professor interromper, repitam a cena mostrando como a Pessoa B pode responder de maneira assertiva.

\section{PAR 4 (PAR MASCULINO/FEMININO):}

A Pessoa A (um líder adulto do sexo masculino do centro comunitário) está a abraçar uma rapariga (Pessoa B) quando ela se dirige ao centro comunitário. Devem representar a cena duas vezes. Na primeira representação, a Pessoa B não está feliz, mas não responde. Depois de o professor interromper, repitam a cena mostrando como a Pessoa B pode responder de maneira assertiva. 


\section{trabalhos dos grupos dos cartazes}

\section{GRUPO DE CARTAZES 1:}

Discutam formas de dizer a um parceiro íntimo que acham que têm uma infecção transmissível sexualmente. Façam um cartaz que mostre três formas de iniciar a conversa. O cartaz pode incluir um desenho.

\section{GRUPO DE CARTAZES 2:}

Discutam formas de dizer ao vosso namorado ou à vossa namorada que querem ter relações sexuais e pretendem saber se a pessoa sente o mesmo ou não. Façam um cartaz que mostre três formas de iniciar a conversa. O cartaz pode incluir uma ilustração de duas pessoas a conversarem sobre esta situação.

\section{GRUPO DE CARTAZES 3:}

Discutam como uma pessoa pode iniciar uma conversa para denunciar o abuso sexual a um pai / mãe ou adulto de confiança. Façam um cartaz que mostre três formas de iniciar a conversa. O cartaz pode incluir uma ilustração de duas pessoas a conversarem sobre esta situação.

\section{GRUPO DE CARTAZES 4:}

Discutam como uma pessoa que tem vindo a praticar relações sexuais pode dizer ao seu parceiro que pretende continuar com o relacionamento, mas não se sente à vontade em relação ao acto sexual. Façam um cartaz que mostre três formas de iniciar a conversa. O cartaz pode incluir uma ilustração de duas pessoas a conversarem sobre esta situação. 


\section{tomar decisões difíceis}

\section{DURAC̣ÃO:}

Etapas 1-5: 40 minutos

Etapa 6: 80 minutos (pode ser feito em casa ou na aula)

\section{MATERIAL:}

Quadro + giz; as duas fichas; papel e quaisquer materiais de arte disponíveis (lápis de cor, marcadores, canetas).

\section{PREPARAC̄̃O:}

Rever a secção sobre a implementação de decisões na Unidade 5 das DIRECTRIZES (o livro que acompanha o presente volume), ou no seu programa. Ler a ficha "Exemplo de Decisões Difíceis" e seleccionar as que pretende usar ou elaborar outras adequadas ao seu contexto. Se for possível, produzir cópias de "Oito

Etapas para Implementar uma Decisão Difícil" e "Exemplo de Decisões Difíceis" para cada aluno (podem ser compiladas numa única ficha).
VISÃO GERAL: Os alunos aprendem etapas para implementar uma decisão e criam bandas desenhadas que retratam uma pessoa a implementar uma decisão difícil.

OBJECTIVOS: Fortalecer a capacidade dos alunos de implementar decisões difíceis tranquilamente e de maneira pensada; fortalecer as habilidades analíticas e de diálogo.

\section{INSTRUC̣ÕES}

1 Para introduzir o tema, diga:

- Pensem numa altura em que tenham tomado uma decisão, mas tiveram problemas em fazê-lo. [Dar exemplos, tais como decidir: terminar o trabalho de casa assim que chegam à casa; usar o preservativo; terminar uma relação infeliz; pedir a alguém para sair convosco; falar a um pai / mãe sobre uma questão sensivel; dizer a um amigo quando se sentiram feridos nos vossos sentimentos; ou fazer o teste do HIV].

- Escrevam qual foi a decisão. Em seguida, pensem em todos os factores que tornaram a decisão difícil de tomar. Anotem todos esses factores.

- Quais são algumas coisas que podem interferir na implementacão de uma decisão?

2 Distribua a ficha "Oito etapas..." e diga ao grupo (use uma alternativa ao exemplo da bolsa de estudos apresentado a seguir, se for mais apropriado):

- Vamos tomar uma decisão imaginária.

- Imaginem que decidiram candidatar-se a uma bolsa de estudos para frequentar a universidade num outro país. Este é o vosso sonho.
3 Usando o exemplo da bolsa de estudos (ou outro exemplo), ajude os alunos a analisar as oito etapas da ficha:

PRIMEIRA ETAPA: O que pode facilitar a tomada da vossa decisão? [Sondar o seguinte: Procurar saber que bolsas estão disponiveis, ter boas notas, voltar a verificar as instruções da candidatura, ter acesso a um computador ou a uma máquina de escrever para submeter a candidatura].

SEGUNDA ETAPA: Quais são as barreiras mais prováveis que poderão enfrentar ao tomarem esta decisão? [Sondar o seguinte: Não há forma de saber o que está disponível, oposição dos pais, problemas de língua na candidatura, falta de tempo para preencher correctamente os formulários, receio de pedir uma carta de recomendação ao professor, as notas podem não ser suficientemente boas, preocupações relacionadas com os custos de transporte].

TERCEIRA ETAPA: Como poderão ensaiar a vossa decisão em privado e em segurança? [Sondar o seguinte: Rascunhar um pedido a um professor, praticar a maneira de abordar os pais, ler com atenção as instruções para o pedido da bolsa e pensar por que razão seriam um bom candidato]. 
QUARTA ETAPA: Discutam a decisão e planifiquem com uma pessoa solidária, que possa prestar apoio. Quem poderá ser? [Sondar o seguinte: um amigo, professor, familiar, pai / mãe, alguém do sector de bolsas, alguém que valorize o ensino universitário, uma outra pessoa que tenha beneficiado de uma bolsa de estudos].

\section{QUINTA ETAPA: Pensem em como}

implementar a vossa decisão da maneira mais segura possível. Que riscos possíveis poderão surgir neste exemplo? [Sondar o seguinte: levantar a questão pode originar um conflito grave com o pai I mãe; qualquer desonestidade numa candidatura pode acarretar graves consequências; ir para um outro país (se a bolsa tiver sido concedida) pode acarretar alguns riscos].

SEXTA ETAPA: Implementem a vossa decisão de acordo com o vosso plano. O que realmente fariam? [Sondar o seguinte: conversar com um amigo, preparar bem o contacto com um professor, pensar na melhor maneira de abordar um pai / mãe que se mostre relutante, trabalhar arduamente para melhorar as notas - em seguida, preencher o formulário de candidatura].
SÉTIMA ETAPA: Se surgirem barreiras na implementação desta decisão, elaborem um plano de acção diferente ou repensem a vossa decisão. Por exemplo: Se os vossos pais não se sentirem à vontade com a ideia de irem estudar num outro país, o que poderão fazer? [Candidatar-se a uma bolsa de estudos dentro do vosso próprio país]. Se as vossas notas não forem suficientemente altas para esta bolsa em particular, o que poderiam fazer? [Procurar uma outra oportunidade de bolsa].

OITAVA ETAPA: Atenção que mesmo que não enfrentem qualquer barreira, têm o direito de reavaliar as decisões e de mudar de ideias. Que factores poderão influenciar-vos a reconsiderar a vossa decisão de se candidatarem a uma bolsa de estudos nesta altura, mesmo que não enfrentem quaisquer obstáculos? [Sondar o seguinte: procurar saber se a universidade local pode oferecer o mesmo programa, decidir se é importante permanecer perto da família, ter receio de viajar para um outro país, necessidade de trabalhar em tempo parcial durante a frequência da universidade, decidir adiar o plano por um ano].

[Poder-se-á enfatizar o valor da educação dizendo algo como "Se qualquer de vós alguma vez tiver uma tal oportunidade de formação académica, espero que a aproveite."] 
4 Distribua a ficha "Exemplo de Decisões Difíceis". Explicar:

- Para praticarem a utilização destas etapas, cada um de vocês deve escolher uma decisão desta lista. A vossa tarefa é criar uma banda desenhada (história em série de quadrinhos ilustrados) com base num personagem que tenha tomado esta decisão. Mostrem como o personagem passa pelas oito etapas do modelo, para a implementação de uma decisão difícil. Poderão avançar por algumas das etapas muito rapidamente; por exemplo, o personagem pode referir-se apenas ao que ele / ela está a fazer. Devem abordar com algum detalhe pelo menos uma ou duas das etapas na vossa banda desenhada.

- Poderão passar o resto desta sessão a iniciar a banda desenhada. Em seguida, devem passar pelo menos uma hora a trabalhar na sua conclusão. [Nota: A segunda hora pode ser trabalho de casa, ou pode ser planificada como uma segunda sessão. Verificar se os alunos entenderam a tarefa].
5 Peça aos alunos que comecem a elaborar as suas bandas desenhadas. Circule pela sala para verificar se todos entenderam a tarefa e ajudá-los a aplicar o modelo de oito etapas.

6 (Pode ser dado como trabalho de casa): Dê mais tempo aos alunos para concluírem a tarefa. Dêlhes a oportunidade de trocar ideias no decurso do trabalho. Quando todas as bandas desenhadas tiverem sido concluídas, considere a possibilidade de pendurá-las na parede ou de colocá-las em livro. 


\section{oito etapas para implementar uma decisão difícil}

PRIMEIRA ETAPA: Considerar o que tornaria a decisão mais fácil de implementar.

SEGUNDA ETAPA: Pensar em obstáculos prováveis que se colocam à implementação de uma decisão.

TERCEIRA ETAPA: Ensaiar a decisão em segurança ou em privado.

QUARTA ETAPA: Discutir a decisão e planificar com uma pessoa solidária.

QUINTA ETAPA: $\quad$ Pensar em como implementar a decisão da maneira mais segura possível.

SEXTA ETAPA: Implementar a decisão de acordo com o plano.

SÉTIMA ETAPA: Se surgirem barreiras na execução da decisão, elaborar um plano de acção diferente, ou repensar a decisão.

OITAVA ETAPA: $\quad$ Atenção ao facto de que mesmo quando as pessoas não enfrentam qualquer barreira, elas têm o direito de reavaliar as decisões e de mudar de ideias. 


\section{exemplos de decisões difíceis}

Você decidiu tentar obter uma bolsa de estudos para se matricular numa universidade num outro país.

Você decidiu não se casar com alguém escolhido pelos seus pais.

Você decidiu casar-se com alguém contra a vontade dos seus pais.

Você decidiu usar o preservativo sempre que tiver relações sexuais.

Você decidiu não ter relações sexuais com o seu parceiro, embora esse parceiro tenha ameaçado deixá-la se você não aceitar.

Você decidiu romper com um parceiro íntimo (namorada ou namorado).

Você decidiu dizer aos seus pais que você (ou sua namorada) está grávida.

Você decidiu deixar de fumar (ou de beber).

Você decidiu deixar um parceiro violento.

Você decidiu dizer aos seus pais que é homossexual.

Você decidiu fazer o teste do HIV.

Você decidiu dizer ao seu parceiro que não sente prazer (ou não alcança o orgasmo) durante as relações sexuais.

Você decidiu dizer ao cônjuge, parceiro sexual ou pais que está infectado pelo HIV.

Você decidiu não seguir uma prática que é comum na sua comunidade (por exemplo, submeter-se à mutilação genital feminina, abandonar a escola numa certa idade ou juntar-se a uma quadrilha).

Você decidiu dizer ao seu parceiro ou cônjuge que você sabe que ele / ela tem um relacionamento sexual com uma outra pessoa.

Você decidiu dizer ao seu parceiro ou cônjuge que tem sido infiel.

126 


\section{o que vocês vêem em mim}

VISÃO GERAL: Os alunos discutem as pressões relacionadas com a aparência física e escrevem sobre um aspecto da sua própria aparência com que se sentem bem. Em pequenos grupos, cada estudante ouve as características não relacionadas com a aparência que os outros admiram em si.

OBJECTIVOS: Permitir que os alunos descrevam os obstáculos enfrentados no uso do preservativo e como estes podem ser ultrapassados; descrever o uso correcto do preservativo; fortalecer as habilidades de pensamento crítico.

\section{INSTRUÇÕES}

1 Inicie a discussão recorrendo às seguintes perguntas orientadoras:

- Muitos factores influenciam a maneira como nos sentimos em relação ao nosso corpo. O nosso corpo é forte e saudável? A sociedade em geral e os órgãos de informação retratam todos os tipos de corpo como sendo atraentes? Como se sentem quando têm que se habituar a muitas mudanças no vosso corpo durante um período de tempo relativamente curto? É dada demasiada ênfase à aparência e não o suficiente às nossas outras qualidades? Hoje vamos explorar algumas destas questões.

- Pensem no momento em que tinham nove anos de idade. Como é que a maior parte das pessoas de nove anos se sente em relação ao seu corpo e à sua aparência? A maior parte das crianças preocupa-se muito com a sua aparência? [Poderá pedir aos alunos que expressem as suas respostas em números entre 1 e 10, onde 1 = não estão nada preocupados e 10 = preocupam-se muito / a maior parte do tempo com isso].
- O que acontece durante a adolescência? A maior parte dos adolescentes sente-se despreocupada e à vontade com a sua aparência, ou ela é motivo de preocupação? [De novo, as respostas podem ser expressas numa faixa de 1-10].

- Que tipo de mensagens e imagens os adolescentes recebem dos filmes e dos anúncios publicitários sobre a sua aparência e qual deve ser a aparência dos seus corpos? Esta pressão é mais intensa nas raparigas ou nos rapazes?

- Os adolescentes são muitas vezes julgados pela sua aparência? A maior parte das pessoas quer ser julgada nesta base? Que outras qualidades positivas as pessoas querem que os outros o seguinte: inteligente, honesto, bom sentido de humor, trabalhador, corajoso, simpático, artístico, músico, atlético, generoso, justo, bom ouvinte, leal e outras qualidades de carácter deste tipo. Produzir uma lista de pelo menos oito a dez qualidades e escrevê-las no quadro. Destacar que ambos os sexos - as raparigas e os rapazes - querem ser apreciados por essas qualidades]. apreciem? [Convidar raparigas e rapazes. Sondar

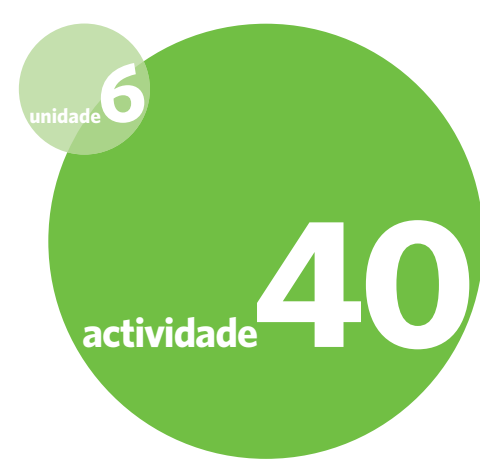

DURAC̣ÃO:

45 minutos

\section{MATERIAL:}

Quadro + giz; uma folha de papel em branco por estudante (se possível, usar papel colorido, de cartaz grande ou outro especial).

\section{PREPARAC̄̃O:}

Se tiver conhecimento de estudantes que tenham um relacionamento hostil, constituir pequenos grupos (Etapa 3) de modo a que esses estudantes não fiquem juntos. É crucial controlar o tempo, nomeadamente durante a Etapa 3, para que cada estudante tenha a sua vez para se elogiado antes do fim da sessão. Se pretender explorar ainda mais a influência da publicidade e das órgãos de informação na imagem corporal, consultar também a Actividade 9. 
2 Pedir aos alunos que peguem numa caneta e papel. Dizer-lhes:

- Pensem em algo sobre a vossa aparência ou corpo com que se sentem bem. Pode ser o vosso sorriso, os olhos, a maneira como andam, os vossos músculos, o cabelo ou a altura. Pode ser o formato do vosso corpo, o nariz, a maneira como dançam ou se mexem, o formato da vossa cara, os vossos braços ou pernas, as vossas mãos, a pele, as vossas covinhas ou lábios. Ou pode ser uma outra coisa qualquer.

- Só para vocês - não terão que partilhar esta informação - escrevam isto. Em seguida, escrevam uma frase poética que descreva essa característica, como por exemplo "O meu sorriso ilumina toda a sala." Ou "Os meus olhos são profundos como o oceano."

- Têm dez minutos. Quando terminarem, guardem o que tiverem escrito num local privado.

3 Depois de os alunos guardarem o que escreveram, divida-os em grupos de cinco. Distribua cinco folhas de papel em branco e um marcador por cada grupo. Explicar:

- Lembrem-se que todos nós queremos ser apreciados por qualidades que não sejam apenas a nossa aparência.

- Começando por uma pessoa no vosso grupo, alguém deve escrever o nome dessa pessoa no canto superior de uma folha em branco. Em seguida, cada um dos membros do grupo deve dizer a essa pessoa algo que admira nela que não esteja relacionado com a sua aparência física. Pode ser uma das qualidades que foram anteriormente mencionadas [consultar o quadro] ou uma outra característica positiva. Pode ser algo que seja imediatamente óbvio, ou poderão considerar alguma coisa sobre a pessoa em relação à qual não tenham prestado muita atenção até agora.

- Quando mencionarem esta qualidade, escrevamna na folha que tenha o nome da pessoa.

- Depois de escreverem a vossa palavra, passem a folha para um outro elemento do vosso grupo. Continuem até que a folha tenha percorrido o círculo.

- Em seguida, repitam o processo para cada um dos restantes membros do grupo. Não se esqueçam de fazer o vosso elogio verbalmente e por escrito. Devem levar apenas alguns minutos para percorrer o círculo referente a cada pessoa. Irei ajudar-vos a controlar o tempo para que cada um tenha a sua vez. [Procurar dividir o tempo restante em cinco segmentos iguais. Circular para verificar se os grupos avançam de uma forma atempada - e respeitosa].

- Antes de começarmos, quais são algumas regras que todos devemos observar ao realizar esta actividade? [Sondar o seguinte: Ser respeitoso; pensar em novos comentários, em vez de repetir o que os outros já disseram; não saltar a vossa vez. Mesmo que haja alguém no grupo de quem não gostem muito, lembrar que todos têm boas qualidades. Tratar os outros da maneira como gostariam de ser tratados].

- Quando tiverem terminado, poderão guardar a vossa "página de elogios.” Mereceram-na! 


\section{mudanças corporais}

VISÃO GERAL: Os alunos criam livros e canções que explicam as mudanças físicas que ocorrem na puberdade.

OBJECTIVOS: Permitir que os alunos descrevam as mudanças físicas básicas da puberdade; fortalecer as habilidades de trabalhar em equipa e de apresentação.

\section{INSTRUCÕ̃ES}

1 Explique que esta aula é sobre as mudanças físicas que ocorrem na puberdade. Perguntar:

- Qual é uma boa idade para aprender sobre os efeitos da puberdade no corpo - depois de atingir a puberdade ou antes? A maior parte das crianças aprende o suficiente sobre o que esperar na puberdade?

- Vão criar materiais sobre a puberdade para os jovens que atingirão essa fase dentro de um ou dois anos. Devem trabalhar em grupos de três. O vosso grupo deve ser constituído apenas por raparigas ou apenas por rapazes. Se o vosso grupo for de raparigas, devem apresentar as mudanças relacionadas com a puberdade nas raparigas. Os grupos de rapazes devem fazer uma apresentação sobre a puberdade nos rapazes.

- Apresentem a informação como preferirem. Por exemplo, podem criar letras de hip-hop, um livro infantil, um cartaz ou inventar e responder a uma carta de uma criança mais nova para a coluna "Caro Doutor" do jornal. Sejam criativos! Podem usar humor, rima, dança, ou ilustrações. Contudo, a informação que apresentarem deve ser exacta e útil. [Se tiverem sido feitos preparativos nesse sentido, explicar aos alunos que vão apresentar as suas criações a um grupo de alunos mais novos].

- Para vos ajudar, vou distribuir uma ficha técnica que diz respeito à puberdade (sobre rapazes ou raparigas) a cada grupo.

2 Forme grupos de três elementos e distribua fichas técnicas. Disponibilize artigos de arte. Diga aos grupos que têm 25 minutos.

3 Se tiver preparado uma apresentação para alunos mais novos: Use o resto da sessão para circular e conversar com cada grupo sobre o trabalho que tiver terminado antes de aprovar esta apresentação. Ajude a corrigir ou a preencher qualquer informação que esteja incorrecta ou em falta.

Se as apresentações forem entre pares na sua própria turma: Peça aos grupos que apresentem o seu trabalho durante esta sessão até ao fim da aula e peça aos restantes que apresentem na aula seguinte. Envolva outros alunos para ajudarem a preencher ou a corrigir informação que esteja em falta ou incorrecta.

4 No fim da sessão, distribua as restantes fichas técnicas sobre a puberdade para que cada aluno tenha um exemplar referente a "Puberdade e Raparigas” e outro a "Puberdade e Rapazes."

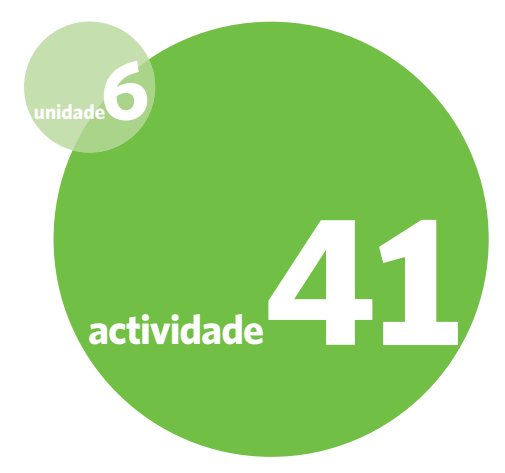

DURAC̣ÃO:

60 minutos (uma ou duas sessões)

\section{MATERIAL:}

Artigos de trabalhos de arte para fazer e "encadernar" um livro (por exemplo, papel, marcadores, papel de cartazes ou folhas grandes, agulha / linha ou agrafador). Fichas técnicas fiáveis sobre a puberdade nos rapazes e raparigas, como as que podem ser encontradas nas DIRECTRIZES

(volume que acompanha o presente livro); acessível em $<w w w . i t s a l l o n e . o r g>$

\section{PREPARAC̣ÃO:}

Rever e familiarizar-se com as fichas técnicas para que possa suplementar ou corrigir as criações dos estudantes.

Fotocopiar as suas fichas técnicas sobre a puberdade nos rapazes e sobre a puberdade nas raparigas. Se for viável, explorar mecanismos para que os seus alunos possam apresentar as suas criações a estudantes préadolescentes. 


\section{puberdade: que mais esperar}

\section{DURACIÓN:}

45 minutos

\section{MATERIAL:}

Quadro + giz; tiras de papel;

Informação e Chave de

Respostas para os Professores

("Mudanças Associadas à

Puberdade e à Adolescência").

\section{PREPARACÃO:}

Copiar cada uma das

"mudanças" na Informação

e Chave de Respostas para

os Professores para uma tira

de papel diferente; dobrar

e colocá-la num envelope.

Rever as mudanças na Etapa

3 e modificar ou adicionar

mudancas que descrevam como

a vida dos jovens muda quando

se aproximam da adolescência

no vosso contexto.
VISÃO GERAL: Os estudantes analisam as mudanças sociais que os rapazes e as raparigas vivem durante a adolescência. (Nota: antes de concluir esta actividade, os estudantes devem concluir a Actividade 41 ou uma outra aula sobre as mudanças físicas que ocorrem durante a puberdade.)

OBJECTIVOS: Permitir que os alunos indiquem três maneiras como os papéis de género mudam durante a adolescência e avaliar, de forma crítica, o impacto destas mudanças nas raparigas, rapazes e relações de género; fortalecer as habilidades de pensamento crítico.

\section{INSTRUCOÕES}

1 Apresente o tema explicando:

- Todos passam por mudanças na puberdade e adolescência. Algumas destas mudanças são desenvolvimentos físicos naturais. Outras não são físicos; são mudanças na maneira como as pessoas vos tratam.

- Vou circular pela sala e pedir a alguns de vocês que retirem uma tira de papel, leiam em voz alta o que nela está escrito e nos digam se o que estão a ler é um desenvolvimento físico que acontece aos jovens de todo o mundo, ou é uma mudança na maneira como a sociedade trata os jovens quando atingem a puberdade e a adolescência. [Se não tiver preparado tiras de papel com estas mudanças, leia as mudanças que se encontram na lista "Mudanças Associadas à Puberdade e à Adolescência", seleccionando aleatoriamente mudanças das duas listas].

- Agora vamos analisar mais detalhadamente as mudanças na forma como os jovens são muitas vezes tratados quando atingem a adolescência. Não estou a falar de mudanças no vosso corpo.
2 Escreva MUDANCAS NA FORMA COMO AS PESSOAS VOS PODERÃO TRATAR na parte de cima do quadro. Por baixo dessa frase escreva RAPAZES num lado do quadro e RAPARIGAS no outro. Explicar:

- O que acontece jovens aos rapazes e as raparigas quando chegam à adolescência? As pessoas tratam-nos de maneira diferente? Ao analisarmos estas mudanças mais detalhadamente, quero que me digam se elas se aplicam às raparigas ou aos rapazes. Se elas se aplicarem a ambos, digam-me se afectam as raparigas e os rapazes da mesma maneira, ou de maneira diferente (e como).

3 Leia cada item da lista a seguir (depois de a terem analisado /modificado) e peça aos estudantes que digam se se aplica a rapazes, a raparigas, ou a ambos. Se não estiverem de acordo, pare, analise em grupo e escreva Rapazes, Raparigas, ou ambos. 
Adolescência: Mudanças na Forma Como as Pessoas Vos Poderão Tratar

- Maior liberdade de movimento em espaços públicos (ruas, parques, centros comunitários, zonas comerciais)

- Menor liberdade de movimento em espaços públicos

- Maior responsabilidade doméstica (por exemplo, tarefas domésticas ou cuidar de crianças)

- Maior responsabilidade para começar a ganhar dinheiro

- Maior pressão para se vestirem de uma forma que cubra o corpo ou que mostre o corpo

- Maior mistura social entre rapazes e raparigas, ou menor mistura social entre rapazes e raparigas

- Rituais de passagem de idade com práticas prejudiciais (como mutilação genital feminina)

- Rituais de passagem de idade sem práticas prejudiciais

- Maior pressão social para se obter experiência sexual

- Maior pressão social para se preparar para o casamento

- Maiores oportunidades de liderança na escola e na comunidade

- Pressão social para ser bem-sucedido no desporto

- Maior chance de ser tirado da escola pela família

- Exposição ao assédio sexual

- Pressão para se juntar a uma quadrilha

- Pressão para cumprir os papéis de género por correr riscos perigosos

- Pressão para trocar o sexo por ofertas, dinheiro ou propinas escolares
4 Divida os alunos em pequenos grupos do mesmo sexo. Peça-lhes que discutam como os papéis de género e a vida dos jovens mudam com a puberdade e a adolescência; perguntar especificamente:

- As mudanças nas expectativas sociais e na experiência que os jovens vivem na puberdade podem ser dramáticas ou pouco importantes?

- O que notam em relação ao que os rapazes enfrentam na puberdade? No geral, a sua liberdade está a aumentar ou a diminuir? Estas experiências perdem importância após a puberdade, ou podem afectar a vida da pessoa até à idade adulta?

- O que notam em relação ao que as raparigas enfrentam na puberdade? No geral, a sua liberdade está a aumentar ou a diminuir? Estas experiências perdem importância após a puberdade, ou podem afectar a vida da pessoa até à idade adulta?

5 Volte a reunir o grupo e pergunte:

- As coisas poderiam ser diferentes? É possível viver de uma forma que seria melhor ou mais justa? Qual é a vossa visão?

- Indiquem uma forma em que a sociedade pode permitir aos jovens uma melhor experiência da puberdade e da adolescência.

Trabalho de Casa: Escrevam duas breves cartas: "Promessa à minha futura filha" e "Promessa ao meu futuro filho." Devem escrever com base no tema de discussão de hoje. 


\section{mudanças associadas à puberdade e à adolescência}

INSTRUÇÕES PARA O PROFESSOR: Copie cada item num pedaço de papel diferente. Dobre e coloque num envelope. Se for necessário, use esta página como chave de respostas para garantir que os alunos distingam correctamente se cada mudança é biológica (no corpo) ou social (na maneira como as pessoas são tratadas por género).

\section{MUDANCAAS NO CORPO}

Crescimento de pêlos no corpo

Maior transpiração

Crescimento dos seios (nas raparigas)

Sonho húmido (nos rapazes)

Mudanças na voz (nos rapazes)

Maior crescimento geral; necessidade de nutrição adicional;

Aumento dos sentimentos sexuais

Sangramento menstrual / secreção de muco (nas raparigas)
MUDANCAS NA MANEIRA COMO AS PESSOAS VOS TRATAM

Novas oportunidades de liderança na escola e na comunidade

Rituais de passagem de idade

Mudança de responsabilidades

Novas pressões relacionadas com a actividade sexual

Novas pressões relacionadas com o casamento

Novas regras sobre como vestir

Novas regras sobre a mistura social entre rapazes e raparigas

Mudança no grau de liberdade permitido 


\section{factos divertidos sobre o corpo}

VISÃO GERAL: Através de palavras cruzadas e de um exercício, os estudantes revêm e aprendem "factos fascinantes" sobre o corpo e a reprodução. (Nota: Esta actividade destina-se a complementar uma palestra básica ou leitura sobre a reprodução; não faz uma apresentação completa do tópico).

OBJECTIVOS: Alargar o conhecimento dos alunos sobre a reprodução humana; aumentar o seu interesse pela biologia reprodutiva.

\section{INSTRUÇÕES}

1 Distribua as palavras cruzadas e explique:

- Temos estado a aprender as etapas básicas da reprodução humana. Para fazermos uma revisão, leiam cada dica (pista) e preencham a resposta correcta nas palavras cruzadas.

- Cada resposta deve caber no número correcto de espaços.

- Nos casos em que uma resposta vertical se cruze com uma resposta horizontal, essas palavras partilham um espaço com a mesma letra.

2 Passados 10-15 minutos, analise as respostas certas circulando pela sala.

3 Distribua a ficha "Factos Divertidos". Explique:

- Agora vamos aprender mais factos sobre o corpo humano. A maior parte desses factos diz respeito à reprodução, mas alguns são apenas factos divertidos sobre o corpo.

- Têm cerca de cinco minutos para ler a lista de factos fascinantes. Em seguida, coloquem um círculo à volta do facto que consideram mais interessante
- Virem-se para duas pessoas sentadas ao vosso lado e vejam se assinalaram o mesmo facto ou outro diferente.

- Quantos constataram que assinalaram o mesmo facto? Factos diferentes? [Levantar as mãos].

- Quantos aprenderam pelo menos uma nova informação?

4 Peça aos alunos que apresentem o facto que consideraram particularmente interessante. Em seguida, forneça mais informação sobre esse facto extraída do Material para os Professores. Se for possível, utilize as perguntas para tentar obter mais informação dos alunos.

5 Se o tempo permitir: Quando chegarem ao facto número 15, peça aos alunos que formem pares para que cada um compare a envergadura e a altura. Explique que isto não está directamente relacionado com a reprodução, mas faz parte de conhecer o nosso próprio corpo.

\section{DURAC̄̃̃:}

Etapas 1-2: 20 minutos

Etapas 3-5: 25 minutos

\section{MATERIAL:}

Cópias das palavras cruzadas para cada aluno; ficha sobre "Factos Fascinantes" e Material para os Professores; uma fonte de informação digna de confiança sobre a biologia reprodutiva, como por exemplo a Unidade 6 e as respectivas fichas técnicas contidas nas DIRECTRIZES (volume que acompanha o presente livro).

\section{PREPARAC̣ÃO:}

Rever o material com atenção, em especial no que diz respeito ao ciclo menstrual, ao sistema sexual e reprodutivo masculino e feminino, à reprodução e gravidez e à infertilidáde e reprodução assistida. Decidir se deve incluir todos os "factos fascinantes" ou eliminar qualquer deles por razões de tempo ou de conteúdo. 


\section{palavras cruzadas sobre o sistema reprodutivo}

Ler cada dica e preencher a resposta correcta. A resposta deve caber no número correcto de espaços. Nos casos em que uma resposta vertical se cruze com uma resposta horizontal, essas palavras partilham um espaço com a mesma letra.

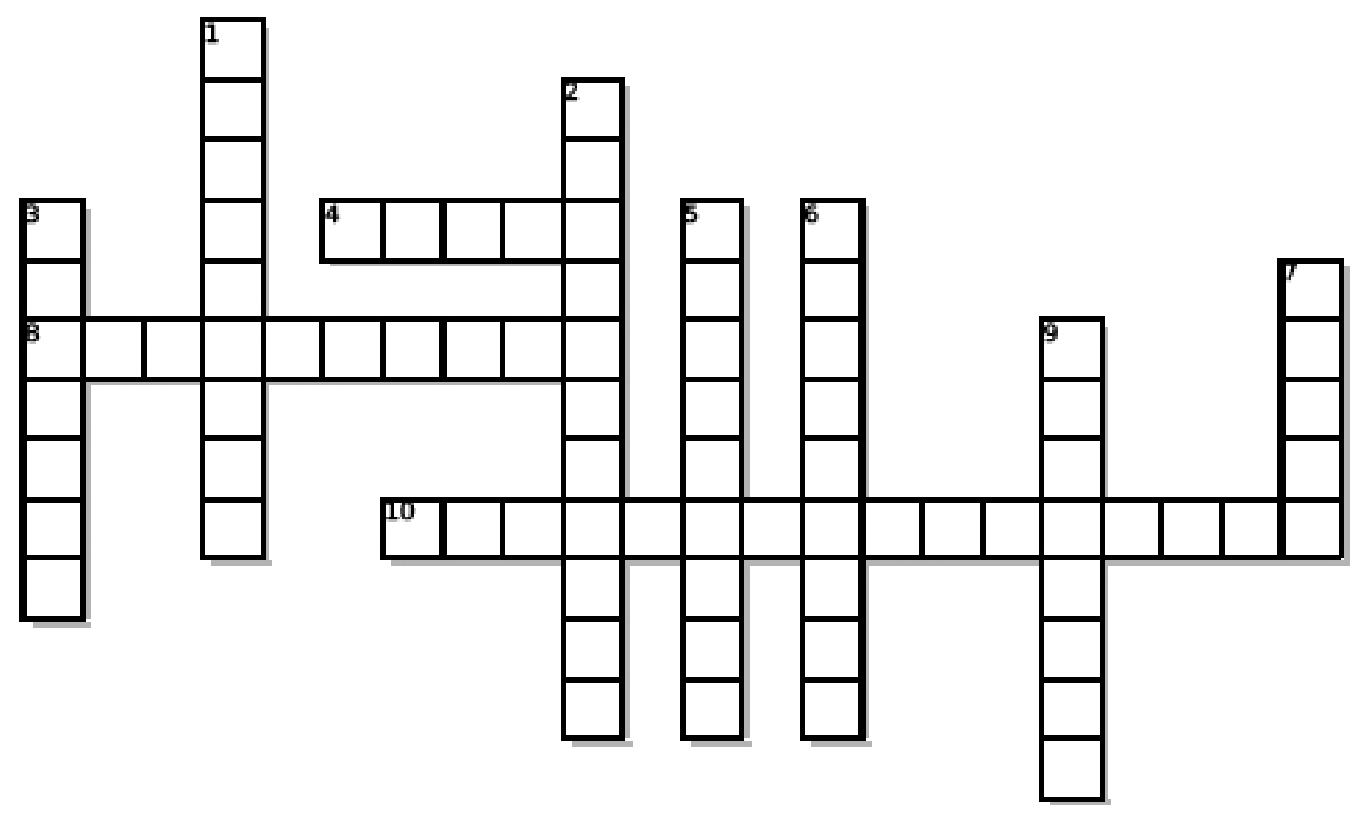

\section{vertical}

1. Local onde o esperma é produzido

2. Expelir sémen durante o sono (duas palavras)

3. Endurecimento do pénis

5. Tempo na vida em que a menstruação da mulher cessa

6. Processo através do qual o corpo de uma criança se desenvolve rapidamente e se torna um corpo adulto e capaz de reproduzir

7. O local onde um bebé se desenvolve

9. Libertação de um ovo do ovário

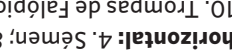

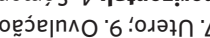

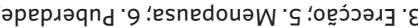
'opluny oyuos ' $Z$ 'o sezsodsay

\section{horizontal}

4. Um fluido espesso que é expelido do pénis durante a ejaculação

8. Libertação vigorosa do sémen do pénis

10. Canais que ligam os ovários ao útero; a fertilização ocorre aqui 


\section{factos fascinantes sobre o nosso corpo}

Que facto consideram mais surpreendente e interessante? Leiam a lista de factos surpreendentes. Assinalem o que acham que realmente vale a pena conhecer.

1 Muitas mulheres sentem que estão mais interessadas no sexo durante os dias férteis do ciclo menstrual.

2 Nos casais que não conseguem ter filhos, a probabilidade de a causa da infertilidade ser de origem masculina é a mesma que ser de origem feminina.

3 O intestino delgado do corpo humano tem cerca de sete metros de comprimento.

4 O desenvolvimento do esperma ocorre nos testículos (que se encontram no escroto). O desenvolvimento adequado do esperma requer uma temperatura do corpo mais baixa que o normal. Porque o escroto se localiza fora do corpo, mantém esta temperatura mais baixa.

5 Embora as mulheres sejam férteis apenas durante alguns dias de cada ciclo menstrual, os homens são férteis continuamente a partir da puberdade.

6 O número normal de espermatozóides é de dezenas de milhões em cada ejaculação.

7 O corpo humano produz cerca de um litro de saliva durante 24 horas.

8 Uma mulher ou uma rapariga pode aprender a identificar quando está a ovular observando mudanças simples no muco que sai da sua vagina. Desta forma, ela pode saber quando está no período fértil (quando pode engravidar) e consegue prever em que dia o seu período menstrual começa.

9 Mais de 50 por cento do corpo humano é constituído por água.

10 A forma da barriga de uma mulher grávida não tem qualquer relação com o sexo do bebé.

11 Perto do fim da gravidez, as articulações das ancas da mulher alargam. Isto permite a expansão da pélvis, possibilitando o movimento do bebé pela região pélvica.

12 Em circunstâncias raras, uma mulher liberta dois óvulos em vez de um. Se os dois forem fertilizados, desenvolver-seão gémeos falsos (não idênticos). Se for fertilizado apenas um óvulo e seguir-se mais uma divisão da célula logo numa fase inicial, desenvolver-se-ão gémeos idênticos.

13 A maior parte dos rapazes tem "sonhos húmidos" durante a puberdade.

14 O sexo de um feto é determinado pelo esperma (do pai), não pelo óvulo (da mãe).

15 O comprimento da envergadura é igual ao comprimento de todo o corpo. 


\section{"FACTOS FASCINANTES" - INFORMAÇÃO ADICIONAL}

\section{Facto Fascinante}

Muitas mulheres sentem que estão mais interessadas no sexo durante os dias férteis do ciclo menstrual.

Nos casais que não conseguem ter filhos, a probabilidade de a causa da infertilidade ser de origem masculina é a mesma que ser de origem feminina.

O intestino delgado do corpo humano tem cerca de sete metros de comprimento.

O desenvolvimento do esperma ocorre nos testículos (que se encontram no escroto). O desenvolvimento adequado do esperma requer uma temperatura do corpo mais baixa que o normal. Porque o escroto se localiza fora do corpo, mantém esta temperatura mais baixa.

Embora as mulheres sejam férteis apenas durante alguns dias de cada ciclo menstrual, os homens são férteis continuamente a partir da puberdade.

O número normal de espermatozóides é de dezenas de milhões em cada ejaculação.

7

O corpo humano produz cerca de um litro de saliva durante 24 horas.

Uma mulher ou uma rapariga pode aprender a identificar quando está a ovular observando mudanças simples no muco que sai da fértil (quando pode engravidar) e consegue prever em que dia o seu período menstrual começa.

\section{Informação Adicional}

Este aumento do desejo sexual ajuda a garantir que o acto sexual ocorra no momento mais propício para perpetuar a espécie. (Discutir no contexto da evolução).

Em alguns lugares, as mulheres são culpadas pela infertilidade porque os homens não percebem que o problema pode ser deles. Muitas vezes é difícil determinar a causa exacta da infertilidade. (Consultar também a ficha técnica sobre Infertilidade).

No corpo, o intestino delegado está enrolado e ocupa uma pequena área.

O calor constante à volta do escroto (por exemplo, trabalhar perto de uma fornalha, ou até usar calças e roupa interior apertadas que aumentam a temperatura do corpo do escroto / testículos) pode reduzir o número de espermatozóides. (Consultar também a ficha técnica sobre os Sistemas Sexual e Reprodutivo).

Com a idade, a sua fertilidade diminui gradualmente. (Consultar também a ficha técnica sobre o Ciclo Menstrual).

O esperma amadurece nos testículos em cerca de 75 dias. (Consultar também a ficha técnica sobre os Sistemas Sexual e Reprodutivo - sexo masculino).

Além de água, a saliva contém produtos químicos, incluindo enzimas, usados para decompor os alimentos.

Se uma mulher souber quando está a ovular, ela pode usar esta informação para tomar medidas com vista a evitar a gravidez ou então para engravidar. (Consultar também a ficha técnica sobre o Ciclo Menstrual) 


\section{"FACTOS FASCINANTES" - INFORMAÇÃO ADICIONAL}

\begin{tabular}{|c|c|c|}
\hline \multicolumn{2}{|r|}{ Facto Fascinante } & Informação Adicional \\
\hline 9 & Mais de 50 por cento do corpo humano é constituído por água. & E o vosso maior órgão é a vossa pele! \\
\hline 10 & $\begin{array}{l}\text { A forma da barriga de uma mulher grávida não tem qualquer } \\
\text { relação com o sexo do bebé. }\end{array}$ & $\begin{array}{l}\text { Um estudo sobre as mulheres grávidas não encontrou qualquer relação entre o } \\
\text { formato da barriga e o sexo do bebé. }\end{array}$ \\
\hline 11 & $\begin{array}{l}\text { Perto do fim da gravidez, as articulaç̃os das ancas da mulher } \\
\text { alargam. Isto permite a expansão da bacia, permitindo o } \\
\text { movimento do bebé pela região pélvica. }\end{array}$ & $\begin{array}{l}\text { Por vezes, uma mulher tem de ter cuidado em relação a movimentar-se já no } \\
\text { fim da sua gravidez, uma vez que as articulações alargadas podem fazer com } \\
\text { que ela se sinta trémula. (Consultar também a ficha técnica sobre o Parto e } \\
\text { Amamentação). }\end{array}$ \\
\hline 12 & $\begin{array}{l}\text { Em circunstâncias raras, uma mulher liberta dois óvulos em vez de } \\
\text { um. Se os dois forem fertilizados, desenvolver-se-ão gémeos falsos } \\
\text { (não idênticos). Se for fertilizado apenas um óvulo e seguir-se mais } \\
\text { uma divisão da célula logo numa fase inicial, desenvolver-se-ão } \\
\text { gémeos idênticos. }\end{array}$ & $\begin{array}{l}\text { Os gémeos falsos têm genes como quaisquer dois irmãos. Mas os gémeos } \\
\text { idênticos são provenientes do mesmo núcleo. O seu ADN (genes) é quase } \\
\text { idêntico. (Consultar também a ficha técnica sobre a Reprodução e Gravidez). }\end{array}$ \\
\hline 13 & $\begin{array}{l}\text { A maior parte dos rapazes tem "sonhos húmidos" durante a } \\
\text { puberdade. }\end{array}$ & $\begin{array}{l}\text { O sonho húmido (ou ejaculação nocturna) ocorre quando um rapaz ou um } \\
\text { homem ejacula enquanto dorme. Os sonhos húmidos são completamente } \\
\text { normais e não são de todo prejudiciais. }\end{array}$ \\
\hline 14 & $\begin{array}{l}\text { O sexo de um feto é determinado pelo esperma (do pai), não pelo } \\
\text { óvulo (da mãe). }\end{array}$ & $\begin{array}{l}\text { Em alguns locais, as mulheres estão sob pressão cultural para gerar filhos } \\
\text { homens. Porém, é o esperma do pai que determina o sexo da criança. } O \\
\text { embrião recebe um cromossoma } X \text { do óvulo da mãe e um cromossoma } X \text { ou } \\
\text { cromossoma } Y \text { do esperma do pai. Se o esperma tiver um cromossoma } X, 0 \\
\text { embrião terá XX e será do sexo feminino; se o esperma tiver um cromossoma Y, } \\
\text { o embrião terá XY e será do sexo masculino. (Consultar também a ficha técnica } \\
\text { sobre a Reprodução e Gravidez. }\end{array}$ \\
\hline 15 & $\begin{array}{l}\text { O comprimento da envergadura é igual ao comprimento de todo o } \\
\text { corpo. }\end{array}$ & Confirmem! \\
\hline
\end{tabular}




\section{reprodução: mais do que uma questão particular}

\section{DURAC̄ÃO:}

Etapas 1-6: 45 minutos

Etapa 7 (trabalho de casa): 40 minutos

Etapas 8-11 (facultativo): 40 minutos

\section{MATERIAL:}

Cópias das fichas do aluno. Para os alunos que abordam os temas A-F da ficha: cópias de fichas técnicas sobre a Selecção do Sexo; Infertilidade e Reprodução Assistida; Parto e Amamentação; e Aborto nas DIRECTRIZES (o volume que acompanha o presente livro).

\section{PREPARAC̄ÃO:}

\section{Rever e alterar (consoante as} necessidades) os tópicos na ficha. Fotocopiar a ficha ou escrever a lista final de tópicos no quadro antes do início da aula. Fotocopiar as fichas técnicas seleccionadas. Explorar onde os alunos poderiam submeter uma compilação do seu trabalho final (por exemplo, um jornal local, como uma série de "comentários de um minuto" num programa de rádio, na assembleia de uma escola ou como um livro).

VISÃO GERAL: Os alunos ficam a conhecer 15 questões contemporâneas de saúde e políticas públicas relacionadas com a reprodução (desde a paternidade na adolescência até à escolha do sexo). Escrevem respostas pessoais num diário e compilam / editam resumos num artigo simples para o ensino público.

OBJECTIVOS: Aumentar o conhecimento e a preocupação dos alunos em relação a aspectos de saúde e políticas públicas relativos à reprodução; fortalecer as suas habilidades de escrita e de edição; aumentar a sua convicção de que podem ter algo a dizer na comunidade.

\section{INSTRUCÕES}

1 Explique:

- Temos estado a estudar a reprodução humana. A reprodução é sempre uma questão particular, de interesse apenas para as pessoas envolvidas? $\mathrm{Ou}$ existirão alguns aspectos da reprodução que sejam de interesse público, por exemplo para os profissionais de saúde, comunidades e outros? [Sondar: como financiamento aos serviços de saúde, leis sobre o aborto, regulamentos nos hospitais, etc.].

- Com efeito, a saúde reprodutiva é uma questão pública importante. Muitas vezes é fonte de controvérsia. No mundo moderno - com novas tecnologias, HIV e normas culturais em mudança é importante conhecer as questões relacionadas com a reprodução. Elas podem afectar as vossas vidas.

- Hoje vamos começar um projecto em que cada um de vós vai explorar um tema que seja de interesse, ou que tenha um significado pessoal para vós. Os produtos finais serão partilhado com a comunidade. [Explicar, por exemplo, produzindo um artigo para o jornal local].
2 Percorra a lista de tópicos e peça aos alunos que se ofereçam para dar definições ou explicações breves. Esta medida irá garantir que todos tenham pelo menos um conhecimento básico do tópico. Em seguida, explicar:

- Cada um deve escolher um tópico que tenha algum significado pessoal, importância ou interesse para vós. Não se trata de um grande projecto de pesquisa! Devem escrever não mais do que dois parágrafos grandes e terão perguntas simples de orientação para cada parágrafo. Mas estes parágrafos devem ser o melhor que conseguirem escrever.

- Hoje vão inscrever-se no vosso tópico e aprender um pouco sobre o mesmo. Em relação a alguns tópicos, dar-vos-ei um parágrafo ou uma página para lerem. Quanto aos outros tópicos, terão que entrevistar três pessoas da turma e registar as suas opiniões. 
3 Reveja as instruções relativas ao trabalho de casa que se encontram na ficha. Se não tiver cópia da ficha para distribuir pelos alunos, copie para o quadro as instruções referentes ao parágrafo "flash noticioso".

4 [Se estiver a incluir a actividade opcional de edição]: Amanhã vão trocar apenas o vosso segundo parágrafo (clip de notícias) com outro aluno. Devem trabalhar em conjunto para editar o que escreveram de modo que seja claro, gramaticalmente correcto, organizado e interessante. Iremos compilar estes clips de notícias num artigo sobre "Questões Contemporâneas na Gravidez e Parto", a ser partilhado na exemplo, um jornal ou estação de rádio local].

5 Certifique-se de que a tarefa está clara. Distribua uma folha em que os alunos se inscrevem nos seus tópicos. Incentive-os a falarem consigo caso necessitem de esclarecimento de qualquer dos tópicos. Peça-lhes que se inscrevam num tópico que não tenha sido escolhido por mais ninguém.
6 Reserve o tempo que resta para os alunos começarem:

Para os alunos que seleccionem os tópicos A-F: Dêlhes cópias do material de leitura e peça-lhes para começarem a ler. (Se eles puderem levar as cópias do material escrito para casa, poderão terminar a leitura em casa).

Para os alunos que seleccionem os tópicos G-N: Peçalhes que comecem a entrevistar os colegas na aula e a tomar notas. Incentive-os a procurar opiniões diferentes, se puderem. (As entrevistas também podem ser concluídas em casa, por exemplo, com os membros da família.)

7 Reserve cinco minutos para esclarecer o trabalho de casa.

\section{Trabalho de Casa:}

Se ainda não tiverem terminado a leitura, podem concluir em casa. Podem também entrevistar pessoas em casa. Em seguida, escrevam os vossos dois parágrafos. Lembrem-se de responder às perguntas na ficha e de escrever cada parágrafo numa página diferente.

Ver as Etapas 8-11 na página seguinte (actividade de edição opcional). 


\section{ACTIVIDADE OPCIONAL:}

\section{EDITAR, PARTILHAR E PRODUZIR}

8 Peça aos alunos que formem pares para editar o seu segundo parágrafo (clip de notícias). Se dois ou mais alunos estiverem a trabalhar no mesmo tópico, junte-os e estimule-os a sintetizar o que escreveram num único clip para que os leitores não fiquem confusos ou entediados.

9 Pergunte aos alunos:

- O que caracteriza a boa escrita? [Sondar o seguinte: clareza; evitar a repetição; boa organização; bom uso do vocabulário; poder emocional, se for apropriado; gramática correcta. Escrever no quadro].

- Qual é uma boa forma de dar feedback sobre o estilo de escrita de uma outra pessoa? [Sondar o seguinte: mencionar alguns aspectos positivos de que gostaram; ser sensivel e respeitoso ao fazer uma crítica; oferecer algumas sugestões, mas não rescrever o trabalho da pessoa].

- Qual é uma boa forma de aceitar feedback? [Sondar o seguinte: agradecer a pessoa pelas boas sugestões; reconhecer onde têm dificuldades ou necessitam de ajuda; pedir mais feedback na vossa tentativa seguinte].
10 Peça aos alunos que dêem feedback uns aos outros; têm dez minutos para o parágrafo da primeira pessoa, dez minutos para o parágrafo da segunda pessoa e dez minutos para que cada um deles possa fazer quaisquer revisões finais. Anuncie sempre que cada segmento de dez minutos tiver terminado.

11 Recolha os parágrafos revistos (assim como as declarações pessoais). Coloque todos os clips de notícias na parede para que todo o grupo possa ler. Se o tempo permitir (ou no dia seguinte): Convide alguns alunos para partilharem o seu parágrafo de resposta pessoal ou o seu clip de notícias final.

Situação ideal: Envolver os alunos na compilação de clips de notícias. Peça-lhes que agrafem os clips de notícias, ou que os editem num único ficheiro e envie-os para um jornal ou para um outro destino para educar as pessoas. Incentive-os a usarem a sua criatividade ao compilar os clips, produzindo um título e elaborando uma carta de apresentação para enviar o produto final. 


\section{temas contemporâneos sobre a gravidez e parto}

INSTRUCCÕES SOBRE COMO ESCREVER O SEU TEMA: Devem escrever dois parágrafos. Coloquem-nos em folhas de papel diferentes. O primeiro parágrafo é uma resposta pessoal. Devem escrever apenas os vossos sentimentos em relação ao tema. Caso o desejem, poderão escrever sobre quaisquer experiências que tiveram que estejam relacionadas. O segundo parágrafo deve ser um "resumo ou clip de notícias." O objectivo deste clip de notícias é educar outras pessoas.

\section{PREPARAC̣ÃO DO VOSSO CLIP DE NOTÍ́CIAS:}

1 Recolham informação sobre o vosso tema. Para os temas A-F, a informação pode ser obtida dos materiais indicados. No caso dos temas G-N, a informação deve ser recolhida de breves entrevistas com três pessoas; podem ser colegas de turma mas, se for possível, procurem opiniões variadas.

2 Expliquem qual é o assunto.

3 Descrevam por que este assunto é "notícia" ou por que a questão é controversa ou motivo de preocupação pública.

4 Terminem o parágrafo com uma conclusão ou com perguntas de reflexão para o vosso leitor. Ao escreverem este parágrafo, lembrem-se que se destina a uma audiência pública, por exemplo leitores de jornais ou ouvintes de rádio.

5 Por último, no fundo da página indiquem se obtiveram a vossa informação através de leituras ou de entrevistas a pessoas. 


\title{
gravidez e parto: temas contemporâneos e perguntas de orientação
}

\author{
TEMAS ‘LER E PENSAR’ (A-F)
}

A Selecção de sexo em locais onde se dá preferência a filhos do sexo masculino Ver: Ficha técnica sobre Selecção do Sexo.

Pensar no seguinte: Qual é a solução para este problema a longo prazo?

B Reprodução Assistida (tecnologias para ajudar casais inférteis) Ver: Ficha técnica sobre Infertilidade e Reprodução Assistida.

Pensar no seguinte: Como se sente em relação a recrutar e pagar a uma outra pessoa para levar a cabo uma gravidez (maternidade de substituição)?

C Parto por cesariana: Por vezes, esta cirurgia é efectuada sem necessidade; outras vezes não está disponível quando é necessária. O que é certo?

Ver: Ficha técnica sobre Parto e Amamentação (secção sobre parto por cesariana).

Pensar no seguinte: De que forma os factores económicos influenciam o número de cirurgias de cesariana?

D Quando o aborto não é opção: Aborto forçado ou maternidade forçada. Ver: Ficha técnica sobre o Aborto.

Ver: Secção da Unidade 7 sobre gravidez indesejada e aborto.

Pensar no seguinte: Alguém deve ser forçado a praticar o aborto? Alguém deve ser forçado a levar a cabo uma gravidez indesejada?

\section{E Fístula obstétrica}

Ver: Ficha técnica sobre Parto e Amamentação (secção sobre fístula obstétrica).

Pensar no seguinte: Porque mais pessoas não estão informadas sobre este problema?

$\mathrm{O}$ que pode ser feito em relação a isso?

\section{F Estar grávida e ser seropositiva}

Ver: Ficha técnica sobre Parto e Amamentação (secção sobre ser seropositiva e estar grávida).

Ver: Ficha técnica sobre Reprodução e Gravidez (secção sobre como promover uma gravidez saudável).

Pensar no seguinte: Quais são os seus sentimentos em relação a este assunto? 


\section{gravidez e parto: temas contemporâneos e perguntas de orientação}

\section{TEMAS PARA ENTREVISTAR Y REFLEXIONAR (G-O)}

\section{G Paternidade na adolescência}

Entrevistar três pessoas. Perguntar: Os rapazes adolescentes estão prontos para ser pais? A maior parte dos pais adolescentes mantém-se responsável e activo na vida dos seus filhos? Que responsabilidade os rapazes têm na prevenção da gravidez indesejada?

\section{H Facilitar a gestão da menstruação para as raparigas}

Entrevistar três raparigas. Perguntar: $\mathrm{O}$ que faz a maior parte das raparigas para se manter limpa e absorver o fluxo de sangue durante a menstruação? O custo constitui um problema? As cólicas menstruais constituem um problema?

| Adopção: Conhecer ou não conhecer o pai-mãe / filho biológico

Muitos bebés são adoptados por alguém que não conhece os seus pais biológicos. Por vezes, a criança recebe informação sobre um ou os dois pais biológicos, ou pode até ter contacto com um dos pais biológicos. Por vezes, há informação disponível, ou o contacto é possível. Entrevistar três pessoas. Perguntar: O que acha que é melhor? Uma criança deve receber informações sobre um pai biológico? Uma criança deve ter a oportunidade de contactar o seu pai biológico?

JAulas de parto: Preparar os pais e as mães para o parto e dotá-los de competências parentais.

Em alguns locais, os casais (pais e mães juntos) recebem aulas para se prepararem para ter um filho. Aprendem sobre o parto e como cuidar do bebé. Entrevistar três pessoas. Perguntar: Estas aulas são necessárias na nossa comunidade? Que diferença poderia fazer se os pais tivessem este tipo de informação?

K A presença do pai durante o parto do seu filho

Entrevistar três pessoas. Perguntar: O pai deve estar presente na sala de parto quando o seu filho nasce? Esta experiência pode afectar a sua ligação com os filhos?

L Políticas sobre licença de maternidade e licença de paternidade

Entrevistar três pessoas. Perguntar: Quanto tempo de licença acha que as novas mães precisam após o parto? Em alguns países, os pais têm licença; o que acha desta ideia? Quanto tempo de licença os pais devem ter?

M Quem vos ensinou sobre a reprodução e quando?

Entrevistar três pessoas. Perguntar: Quem lhe ensinou sobre de onde vêm os bebés? Que idade tinha? Qual acha que é a melhor maneira de aprender sobre a reprodução humana?

N Políticas do governo que oferecem incentivos para influenciar o tamanho da família

Alguns governos que querem que a sua população cresça oferecem dinheiro aos casais que têm mais filhos. Alguns governos estão preocupados que a sua população esteja a crescer demasiado rápido e oferecem dinheiro ou presentes para as pessoas que tenham feito uma operação para deixarem de ter filhos. Entrevistar três pessoas. Perguntar: Concorda com algumas destas políticas? Porquê ou porque não?

\section{O Grávida e na escola?}

Todos os dias, raparigas adolescentes que ainda frequentam a escola engravidam. Em alguns lugares, elas estão autorizadas a continuar a frequentar a escola, mas noutros elas são obrigadas a desistir. Entrevistar três pessoas.

Perguntar: Qual é a melhor política para apoiar as adolescentes e os seus bebés? Qual é o papel e a responsabilidade do pai? 


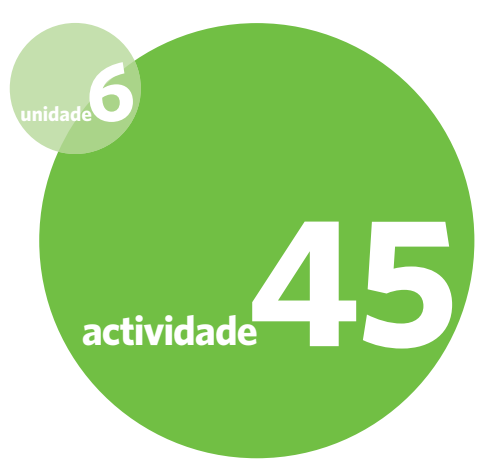

DURAÇÃO:

60-85 minutos, dependendo do número de estudos de caso usados

\section{MATERIAL:}

Quadro + giz; uma cópia de cada estudo de caso.

\section{PREPARAC̄̃̃:}

Rever os oito estudos de caso apresentados. Modificar

ou substituir consoante as necessidades para que sejam adequados e autênticos para o vosso contexto. Rever o conteúdo relevante (secção da Unidade 6 sobre "Quando a gravidez continua" e fichas técnicas sobre a Reprodução e Gravidez e sobre Parto e Ámamentação) em DIRECTRIZES, volume que acompanha o presente livro) e que esta disponível em www.itsallone. org. Ou consultar uma outra fonte de informação fiável.

\section{a cada minuto de cada hora: histórias de mortes relacionadas com a gravidez}

VISÃO GERAL: Os estudantes lêem os estudos de caso sobre a mortalidade materna. Através de presentações teatrais e de discussão, exploram como estas mortes podiam ter sido evitadas.

OBJECTIVOS: Permitir que os estudantes descrevam as principais maneiras como a pobreza e a desigualdade de género levam à morte (e a graves problemas de saúde) nas mulheres grávidas; identificar como estes resultados podiam ser prevenidos; aumentar a sua preocupação em relação à mortalidade materna como um problema; fortalecer as suas habilidades analíticas.

\section{INSTRUCÕES}

1 Escreva "Mortalidade Materna" no quadro. Faça as seguintes perguntas e escreva as respostas no quadro:

- O que acham que o termo "mortalidade materna" significa? [Sondar uma definição semelhante a: "a morte de uma mulher por uma causa relacionada com a gravidez ou o parto."]

- Aqui estão alguns quebra-cabeças: Quantas vezes acham que uma mulher ou rapariga morre em algum lugar do mundo por causas relacionadas com a gravidez? Uma por semana? A cada dez minutos? Todos os dias? [Permitir algumas suposições]. A resposta é a cada dois minutos de cada dia, cada dia do ano. Durante a hora que passámos a aprender sobre a questão da mortalidade materna, 35 mulheres e raparigas morrerão desta causa. Todos os anos, isto equivale a 300,000 mortes. Um número muito maior de mulheres e raparigas não morre, mas sofre outros problemas relacionados com a gravidez.

- Acham que estas mortes estão espalhadas uniformemente em todo o mundo? Por exemplo, que percentagem de mortes maternas advinham que ocorre nos países em "desenvolvimento" (países que não são tão industrializados ou ricos)? Um décimo? Metade? Dois terços? [Permitir algumas suposições]. A resposta é 99 por cento. A mortalidade materna é extremamente rara nos países mais "desenvolvidos".

- As raparigas adolescentes mais jovens estão também em maior risco. Comparativamente às mulheres adultas, as raparigas menores de 15 anos apresentam uma probabilidade significativamente maior de morrer durante o parto.

- Quantas mortes maternas acham que são evitáveis? Uma pequena proporção? Mais de metade? Um terço? [Permitir algumas suposições]. Os peritos indicam que "quase todas" estas mortes são preveníveis.

- Hoje vamos aprender mais sobre estes assuntos. Constatarão como podem ajudar a fazer a diferença nas vossas próprias vidas e nas vidas dos outros. 
2 Divida a turma em grupos de acordo com o número de estudos de caso que estiver a usar. Dê a cada grupo um estudo de caso para ler, dobrado para que não o leiam ainda. Explicar:

- Cada grupo está a receber um estudo de caso diferente sobre uma morte materna. Depois de lerem o vosso estudo de caso, discutam no grupo, fazendo as seguintes perguntas: O que correu mal? (Quais são as coisas principais que contribuíram ou conduziram à morte da mulher ou da rapariga?) O que devia ter acontecido? (O que podia ter sido feito de diferente e salvo a sua vida?) [Escreva as duas perguntas principais no quadro].

- Vão representar a história da mulher em breves peças teatrais (de dois ou três minutos). Primeiro, vão representar a vossa peça como está escrita no caso. Em seguida, devem voltar a representá-la, incorporando as medidas que deviam ter sido tomadas para salvar a vida da mulher. As mesmas pessoas podem representar uma segunda vez, ou podem escolher membros diferentes do vosso grupo para representar na segunda presentação.

3 Peça que todos os grupos representem as suas duas peças teatrais.
4 Reserve 15 minutos depois da apresentação das presentações para discutir os seguintes aspectos:

- Como se sentiram depois de ouvirem estas histórias? O que foi que vos fez sentir assim no estudo de caso?

- Pessoas singulares, membros de famílias, comunidades, profissionais de saúde e governos todos podem agir para prevenir estas mortes. Que coisas importantes podem ser feitas antes de uma mulher engravidar para proteger a sua saúde (e a saúde do seu recém-nascido)? [Escrever as respostas no quadro; completar o que for necessário].

- O que pode ser feito durante a gravidez? [Escrever as respostas no quadro; completar o que for necessário].

- O que pode ser feito durante o parto? [Escrever as respostas no quadro; completar o que for necessário].

- Como podemos prevenir as mortes maternas de raparigas menores de 15 anos?

- Como utilizarão a informação que aprenderam hoje? 


\section{estudos de caso sobre a mortalidade materna}

HISTÓRIA DE RANI: Quando Rani tinha 13 anos, a mãe morreu durante o parto. O pai dela explicou-lhe que tinha que deixar de frequentar a escola para poder cozinhar e ajudar a cuidar dos irmãos mais novos. O irmão mais velho, que ainda estava na escola, tentou ajudar Rani para que ela continuasse com os seus estudos, mas ela logo desistiu porque as suas outras tarefas deixavam-lhe pouco tempo para estudar. Aos 19, Rani casou-se com Ramesh e foi viver com ele e com os pais dele. A família de Ramesh, que dava valor ao conhecimento que Rani tinha de cuidar de crianças, queria que ela tivesse filhos imediatamente.

Quando Rani engravidou, o marido estava sempre a falar sobre ter um rapaz. Mas, em segredo, Rani imaginava que teria uma menina e prometeu a si própria que a sua filha iria concluir os estudos, coisa que ela não conseguiu fazer. Depois de oito meses, e de acordo com os costumes locais, Rani regressou à aldeia dos pais para dar à luz. Quando as dores do parto começaram, um médico local veio para vê-la . Quando depois de um dia inteiro e uma noite de trabalho de parto o bebé ainda não tinha nascido, ele aconselhou-a ir ao hospital mais próximo, situado a 100 quilómetros de distância. Por causa da hora tardia, ninguém conseguiu organizar transporte para Rani, o que veio a acontecer no dia seguinte de manhã. Quando Rani finalmente chegou exausta ao hospital distrital, conseguiu dar à luz o seu bebé. Embora o marido tivesse ficado desiludido por não ser um rapaz, Rani sussurrou a sua promessa à filha recém-nascida. Entretanto, ela começou a sangrar mais abundantemente. Embora o pessoal de saúde tivesse rapidamente organizado uma transfusão de sangue, Rani entrou em coma. Apesar dos esforços do pessoal do hospital, Rani tinha perdido muito sangue e morreu da mesma maneira que a mãe.

HISTÓRIA DE CHARITY: Charity tinha 15 anos. Passava o tempo na escola, a estudar em casa e a realizar tarefas domésticas. Algumas vezes saiu com um homem que conhecera perto da escola. Ele deu-lhe presentes e algum dinheiro, que ela usou para pagar os livros, e teve relações sexuais com ele. Ela perguntou-lhe sobre o uso de preservativos, sobre os quais ela tinha aprendido na escola, mas ele disse-lhe para não se preocupar. Ela não gostava muito dele, pelo que decidiu não voltar a vê-lo. Porém, Charity logo constatou que estava grávida. Quando disse aos pais, o pai bateu-lhe, mas não foi expulsa de casa. Ela desistiu de ir à escola depois de alguns meses e passou a viver com uma tia numa outra cidade. A família tinha acordado que a tia devia criar a criança para que ninguém soubesse da gravidez de Charity. Quando ela entrou em trabalho de parto, a tia disse-lhe para ser forte, que o bebé nasceria por si. Porém, o bebé ficou preso no canal do parto. A tia chamou uma parteira local, que veio e cortou Charity com uma lâmina para aumentar a abertura da vagina para que o bebé pudesse sair. O bebé saiu rapidamente e Charity pensou que logo voltaria à sua antiga vida, mais triste, porém mais madura. Contudo, ao fim de alguns dias, ela reparou que o local onde tinha sido cortada infectara. Passados mais alguns dias, Charity teve febre alta. A tia queria levá-la ao hospital, mas ela recusou-se. Tinha receio que alguém no hospital descobrisse que tinha estado grávida. Quando a febre piorou no dia seguinte de manhã, a tia chamou uma ambulância, mas era demasiado tarde. Charity morreu algumas horas depois de chegar ao hospital. 


\section{estudos de caso sobre a mortalidade materna}

HISTÓRIA DE ANA: Ana vivia com o marido numa vila remota dos Andes, na Bolívia. Nunca aprendeu a ler e a escrever. Durante algum tempo, tomou a pílula contraceptiva, mas parou porque o marido opunha-se à contracepção. Quando Ana engravidou, foi uma vez ao centro de saúde local para cuidados pré-natais. Sentiu-se envergonhada no centro de saúde porque não sabia falar espanhol e o pessoal não falava quechua. Sentiu que o médico não estava interessado no caso dela e só queria que se fosse embora. No nono mês de gravidez, Ana começou a sentir dores no baixo-ventre. Uma vizinha que era parteira disse à família de Ana que o bebé estava mal posicionado e que deviam levar Ana ao centro de saúde. Porém, Ana tinha receio de ir por causa da maneira como tinha sido tratada na consulta pré-natal. Além disso, o marido tinha ouvido dizer que os pacientes do posto de saúde tinham que pagar algumas taxas e a família dela não tinha condições de o fazer. Ana ficou em casa. Depois de dez dias, as dores tinham piorado. A parteira persuadiu a família de Ana a levá-la ao centro de saúde. Não tinham acesso a um carro, pelo que fizeram a viagem na sua carroça puxada por cavalos. O centro de saúde situava-se a 15 quilómetros da aldeia, uma viagem longa de carroça. No meio do caminho, Ana começou a sangrar profusamente e morreu.

HISTÓRIA DE FATIMA: Fatima queria ser professora. Todavia, quando tinha 15 anos, os pais casaram-na e ela foi viver com o marido, Ali, um camionista. Os pais de Ali pressionaram o casal a ter filhos, então Fatima deixou de usar contraceptivos. Deu à luz três crianças em cinco anos. Em cada parto, foi ajudada por uma parteira local. Quando estava grávida de oito meses do quarto filho e Ali se encontrava a fazer entregas, Fatima começou a sentir-se muito mal. Porque Ali era quem geria o dinheiro da família, Fatima não tinha dinheiro para pagar transporte até ao posto de saúde. Então ficou à espera que ele regressasse à casa. Quando Ali chegou, Fatima tremia com febre alta e sentia-se muito fraca. Ali preparou a sua ida ao hospital, mas quando lá chegaram, Fatima tinha morrido.

HISTÓRIA DE MARIA CLARA: Maria Clara vivia com o marido, Pedro, e com o sobrinho (filho do irmão que tinha morrido num acidente). Viviam numa aldeia da montanha longe da vila mais próxima, uma viagem de sete horas de burro até ao hospital mais próximo. Quando Maria Clara engravidou, foi ao controlo. O médico disse-lhe que se devia dirigir ao hospital duas semanas antes da data prevista para o parto para que não enfrentasse quaisquer complicações perigosas de última hora, longe dos cuidados de saúde. Quando a gravidez estava a chegar ao fim, Maria Clara ficou nervosa em relação ao facto de ter de deixar a sua casa. Pedro reclamava o facto de ela vir a estar fora tanto tempo, dizendo que não sabia cozinhar. Ela também sabia que Pedro bebia muitas noites e por vezes ficava violento, pelo que temia que ele batesse o sobrinho. Receava também que Pedro passasse tempo com uma mulher que trabalhava no bar que frequentava depois do trabalho; uma vizinha tinha-lhe alertado que a servente do bar fora vista com Pedro. Maria Clara decidiu viajar até ao hospital apenas uma semana antes da data que o médico lhe dissera que o bebé devia nascer. Porém, no dia anterior ao que ela ia partir para o hospital, o bebé nasceu e Maria Clara começou a sangrar. Pedro não pôde transportá-la até ao centro de saúde a tempo de salvá-la e ela morreu. 


\section{estudos de caso sobre a mortalidade materna}

HISTÓRIA DE YERUKNESH: Yeruknesh nasceu numa comunidade remota da Etiópia. Quando tinha 13 anos, enquanto apanhava lenha, foi raptada pelo Sr. Zena, um viúvo de 32 anos com dois filhos, com quem veio a casar-se. Pouco tempo depois, ela engravidou. Yeruknesh não tinha ninguém a quem pedir conselhos, ou com quem conversar sobre os seus problemas. Quando o trabalho de parto dela começou, ficou aterrorizada. Apertando a almofada com força, ela chamou pela mãe, as lágrimas a escorrerem pelo rosto abaixo. Estava com muitas dores, febre alta e a transpirar profusamente. Algumas vizinhas vieram, acenderam uma vela e rezaram por Yeruknesh. O Sr. Zena chamou a parteira tradicional da aldeia, mas esta não estava qualificada para resolver tais situações. Então, o Sr. Zena pediu aos homens da aldeia para levá-la ao hospital. Quando ela chegou ao hospital, o feto era prematuro e Yeruknesh morreu aos 15 anos.

HISTÓRIA DE HUSAN: Saeeda Bibi, que vive em Mardan na província fronteiriça do Noroeste do Paquistão, conta como a sua única filha, Husan Pari, morreu durante o parto com 13 anos. "Quando Husan tinha oito anos, o pai morreu num acidente de automóvel. Receei que se eu também morresse, não haveria ninguém para cuidar da minha filha. Queria que ela se casasse, fosse feliz e protegida. Descobri um par para ela, um agricultor de uma aldeia vizinha. Husan Pari estava muito animada com o seu casamento. Ao fim de três meses, estava grávida e levei-a à parteira tradicional, que lhe deu medicamentos para os vómitos. Nós conseguíamos pagar a Dai em pequenas prestações e gostávamos das suas orações e ervas. Husan trabalhava muito e a sua dieta era de má qualidade — a superstição impedia-a de comer ovos e peixe - e ela emagreceu terrivelmente. Preocupei-me porque não sabia como é que ela iria suportar as dores do parto. Fomos ajudá-la quando ouvimos os seus gritos, mas o bebé não saía. A parteira enervouse, recusou-se a continuar a ajudar e disse que a devíamos levar ao hospital. No caminho, Husan Pari ficou azul, fria como gelo e morreu nos meus braços. Não pude salvá-la, nem ao bebé. Não consigo lembrar-me como chegámos à nossa casa, nem como foi o funeral. A dor era insuportável.”

A história de Yeruknesh e a história de Husan foram adaptadas de White Ribbon Alliance for Safe Motherhood e Stories of Mothers Lost e foram usadas com permissão. Ver <www. whiteribbonalliance.org/exhibit/ default.cfm>. A história de Yeruknesh foi uma contribuição da Medico Socio Development Assistance of Ethiopia. A história de Husan foi submetida pela Blue Veins - Women Welfare and Relief Service of Pakistan. Várias das restantes histórias são relatos multifacetados baseados em situações reais. Os nomes de algumas mulheres foram alterados.
HISTÓRIA DE FLORENCE: Florence era uma mulher solteira de 24 anos que produzia e vendia legumes. Uma noite, ela foi violada ao regressar do mercado. Teve receio de contar a quem quer que fosse e quando o seu período menstrual não apareceu nesse mês, ela descobriu que tinha engravidado em consequência da violação. Embora o aborto fosse legalmente restringido no seu país e fosse normalmente feito em condições não higiénicas, Florence estava determinada a não levar a gravidez a termo. Contactou alguém que introduziu alguma coisa na vagina e lhe disse que o sangramento cessaria dentro de uma semana. No fim dessa semana, Florence continuava a sangrar e também tinha febre alta. Foi ao hospital, onde um médico a internou e lhe receitou antibióticos. No princípio, Florence tinha receio de revelar que tinha feito um aborto porque temia ser castigada, ou até presa. Por fim, acabou dizendo ao médico. O médico, que acreditava que o aborto devia ser seguro e acessível, sentiu imenso por Florence e fez o melhor que pôde para salvar a sua vida. Ele chorou quando ela morreu dez dias depois. 


\section{factos sobre infecções transmitidas sexualmente (ITS)}

VISÃO GERAL: Os alunos fazem cartazes contendo informação importante sobre ITS, incluindo o HIV e SIDA.

OBJECTIVOS: Permitir que os alunos descrevam como as ITS são transmitidas, como prevenir a sua transmissão e onde fazer o teste e obter tratamento; aumentar a sua consciência em relação à importância de procurar fazer o teste e tratamento.

\section{INSTRUÇÕES}

1 Explique que esta aula trata de infecções transmitidas sexualmente - também chamadas ITS — incluindo o HIV e SIDA.

2 Divida a turma em quatro grupos constituídos por elementos de ambos os sexos. Atribua a cada grupo um tópico da lista (ou deixe que sejam eles a escolher; tente abranger todos os tópicos). Explicar:

- No vosso grupo, criem um cartaz informativo sobre o vosso tema. Usem a vossa imaginação!

- O cartaz deve ser o mais minucioso possível. Incluam informação sobre testagem, tratamento e prevenção. Podem utilizar os materiais de recurso. Em alguns casos (por exemplo, em relação aos cartazes sobre "mitos"), poderão entrevistar colegas para a recolha de ideias.

3 Distribua material factual para a elaboração de cartazes. Lembre aos alunos que têm 10 minutos para recolher a sua informação, 10 minutos para discutila e planificar a elaboração de um cartaz e 15 para produzir o cartaz. Circule pela sala para apoiar os grupos enquanto pesquisam, discutem e produzem os seus cartazes. Se não conseguirem concluir os cartazes, dê-lhes mais tempo, ou diga-lhes quando terão mais tempo para concluírem o trabalho.
Numa sessão posterior

4 Se for necessário, dê aos grupos algum tempo para a conclusão dos seus cartazes.

5 Peça a cada grupo que apresente o seu cartaz e responda às perguntas da turma.

6 Exponha os cartazes na sala de aula o máximo tempo possível.

Mitos sobre as ITS

Mitos sobre o HIV e SIDA

Dupla protecção

Cinco factos importantes sobre o HIV e SIDA

O que é clamídia?

ITS e género

De que forma a clamídia e a gonorreia afectam a futura fertilidade?

HPV e herpes: duas ITS importantes

O que é uma infecção do tracto reprodutivo?

\section{TEMAS DE CARTAZES}

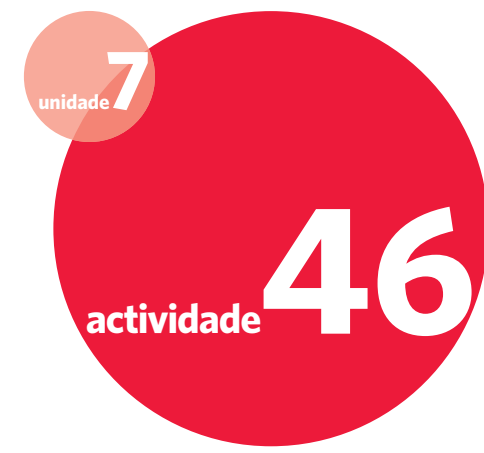

\section{DURACÃO:}

Etapas 1-3: 40 minutos

Etapas 4-6: 40 minutos

\section{MATERIAL:}

Papel de cartazes + marcadores; um exemplar de DIRECTRIZES

(volume que acompanha o presente livro) ou cópias das seguintes páginas desses livros: fichas técnicas sobre Infecções Transmitidas Sexualmente, sobre o HIV e SIDA e sobre Infeccões do Tracto Reprodutivo; e secções da Unidade 7 sobre ITS e HIV. O livro DIRECTRIZES está disponível em $<$ www.itsallone.org>. Ou usar uma outra fonte de informação fiável sobre ITS e HIV.

\section{PREPARAC̄ÃO:}

Se for possível, tirar várias cópias dos materiais acima mencionados. Procurar obter informação sobre onde os jovens podem fazer o teste e ser tratados na sua comunidade. Escrever os tópicos do cartaz no quadro. 


\section{género e uso do preservativo}

\section{DURACÃO:}

Etapas 1-4 (Por que razão algumas pessoas não usam preservativos): 40 minutos

Etapas 5-7 (Uso correcto do preservativo): 15 minutos

\section{MATERIAL:}

Quadro + giz; chaves de respostas dos professores; para as Etapas 1-4: cópias da ficha técnica. Para as Etapas 5-7: cartões (flashcards). Se for apropriado, amostras de preservativos masculinos e femininos para efeitos de demonstração.

\section{PREPARAC̣ÃO:}

Confirmar se existem preservativos femininos localmente e onde podem ser obtidos. Rever a informação sobre os preservativos masculinos e femininos na ficha técnica sobre contraceptivos no fim das DIRECTRIZES Para as Etapas 1-4: rever a ficha técnica e as duas chaves de respostas dos professores. Para as Etapas 5-7: Preparar os flashcards (ver "Etapas Correctas do Uso do Preservativo").

VISÃO GERAL: Os alunos analisam as barreiras (incluindo normas de género) que se colocam ao uso do preservativo e formas de ultrapassar essas barreiras e aprendem como usar o preservativo. Esta actividade destina-se aos alunos que já possuam informação básica sobre o preservativo como método de protecção contra as ITS, o HIV e a gravidez indesejada.

OBJECTIVOS: Permitir que os alunos descrevam os obstáculos enfrentados no uso do preservativo e como estes podem ser ultrapassados; descrever o uso correcto do preservativo; fortalecer as habilidades de pensamento crítico.

\section{INSTRUC̣ÕES}

1 Explique (e escreva as respostas principais):

- Hoje vamos discutir o uso do preservativo. O que sabemos sobre os preservativos? [Sondar o seguinte: Protegem das ITS/HIV e da gravidez indesejada; são usados pelo homem].

- Quem pode usar o preservativo? Existe um preservativo para as mulheres, ou apenas existe para os homens? [Sondar o seguinte: Existe também um preservativo feminino. Oferecer informação básica sobre este método].

- Porque é importante estar informado sobre preservativos? [Sondar o seguinte: Todos os dias as pessoas morrem de SIDA ou de complicações resultantes do aborto inseguro; estas são mortes que podiam ter sido evitadas se as pessoas tivessem usado o preservativo. Os preservativos protegem contra a gravidez, o HIV e outras infecções].

- Se as pessoas sabem da existência do preservativo, isso significa que os usam?
2 Peça à turma que forme pares e distribua a ficha técnica. Explicar:

- Existem muitas razões que fazem com que as pessoas não usem o preservativo, ou que não o usem correctamente. A vossa ficha técnica descreve a experiência de nove casais reais. Também dá sugestões sobre o que podia ter ajudado estes casais.

- Com o vosso parceiro, leiam a situação de cada casal. Em seguida, decidam que solução, ou soluções, correspondem à situação destes casais: o que poderia ajudá-los a usar o preservativo correctamente da próxima vez?

3 Volte a juntar a turma para discutir a situação de cada casal descrito na ficha técnica. Para os casais C, F e I (que envolvem a desigualdade de género), suscite uma maior discussão, se o tempo o permitir.

4 Após analisar a situação de todos os nove casais, dinamize a discussão recorrendo às seguintes perguntas: 
- Quem é responsável pelo uso do preservativo?

- Por que razão as raparigas ou mulheres poderão necessitar de ter acesso ao preservativo feminino? [Sondar o seguinte: Para assumirem a protecção elas próprias se os seus parceiros não usarem o preservativo masculino].

- Como é que as pessoas podem garantir que estão preparadas para usar o preservativo quando precisarem dele?

5 Divida a turma em duas ou três equipas (de aproximadamente 12 a 16 pessoas por equipa). Apresente o tema:

- Uma das razões que fazem com que as pessoas não usem o preservativo é que não sabem como usá-lo. Essa é uma razão pouco válida para se enfrentar um grave problema de saúde; portanto, nós agora vamos aprender a usar correctamente o preservativo masculino. Ter idade suficiente para aprender a usar o preservativo NÃO significa que já estejam prontos para ter relações sexuais, mas é melhor saber usar o preservativo ANTES de precisarem dele, e não depois do acto sexual, quando já é demasiado tarde. Quando se usa o preservativo, podem tomar algumas medidas com antecedência, ou seja, antes de se encontrarem numa situação íntima. Algumas medidas podem ser tomadas quando já se encontram numa situação íntima, mas imediatamente antes da ocorrência do acto sexual. Devem saber o que fazer em relação ao uso do preservativo durante as relações sexuais e devem saber o que fazer com o preservativo depois de usá-lo. [No quadro, escrever "com bastante antecedência," "imediatamente antes," "durante o acto sexual," e "depois do acto sexual."]
6 Explique a actividade:

- Eu dividi todas as etapas inerentes ao uso correcto do preservativo masculino e coloquei cada etapa num cartão diferente. Vou distribuir um conjunto de cartões (flashcards) a cada grupo. [Procurar baralhar os cartões para que não estejam por ordem ao distribuí-los]. Cada equipa deve trabalhar em conjunto para colocar as etapas na ordem correcta.

- Se for possível, cada cartão deve ser segurado por uma pessoa diferente do grupo. Em seguida, organizem o vosso grupo em quatro subgrupos. [Apontar para as quatro opções escritas no quadro]. O primeiro subgrupo deve incluir os que têm os cartões com as primeiras etapas - as que devem ser realizadas com muita antecedência. $\mathrm{O}$ subgrupo seguinte deve ter os cartões referentes às etapas a terem lugar imediatamente antes do acto sexual. O terceiro subgrupo de cartões deve incluir as etapas que podem ocorrer durante o acto sexual. O quarto subgrupo deve mostrar as etapas após o acto sexual. Dentro do vosso subgrupo, tentem também pôr cada etapa por ordem. Depois façam uma fila por ordem do vosso cartão. [Nota: No primeiro subgrupo, isto pode ser um pouco mais difícil].

- Têm cinco minutos. Comecem!

7 Interrompa o processo após cinco minutos e junte todo o grupo. Peça aos alunos que expliquem a ordem das etapas. Interrompa para lhes questionar sobre quaisquer etapas que não estejam na ordem certa (ver chave de respostas). Responda a quaisquer perguntas que possam surgir. 


\section{soluções para habilitar as pessoas a usar o preservativo}

A seguir são apresentadas histórias de nove casais que não usaram correctamente o preservativo. Pensem no que teria ajudado a esta pessoa ou casal em cada uma dessas histórias. Seleccionem uma ou mais "soluções" da lista a seguir e assinalem o número que corresponde a uma das soluções abaixo. Por exemplo, assinalar "2" para indicar "Maior igualdade e poder partilhado entre a rapariga e o rapaz." (Poderão assinalar mais do que um número, se acharem que o casal necessita de mais do que uma solução.)

$\begin{array}{ll}\text { Solução } 1 & \text { Informação sobre o uso correcto do preservativo } \\ \text { Solução } 2 & \text { Maior igualdade e poder partilhado entre a rapariga e o rapaz } \\ \text { Solução } 3 & \text { Melhores habilidades de comunicação } \\ \text { Solução } 4 & \text { Informação sobre onde obter preservativos } \\ \text { Solução } 5 & \text { Uma ideia mais realista do risco de HIV e gravidez } \\ \text { Solução } 6 & \text { Um local seguro para discutir as preocupações sobre o desempenho sexual }\end{array}$

Casal A: Estes dois jovens têm relações sexuais usando o preservativo. Após a ejaculação, o rapaz fica inerte durante cinco minutos. O seu pénis torna-se flácido e mais pequeno e quando se mexe um pouco, fica chocado ao constatar que algumas gotas do seu sémen caem do preservativo para a abertura da vagina da sua namorada.
O Casal A precisa:
2
3
4
5
6

Casal B: Estes dois jovens decidiram ter relações sexuais e usar o preservativo. Um parceiro procura no mercado local, mas não encontra à venda preservativos masculinos, nem femininos. O outro pensa que preservativos podem estar disponíveis na escoa, mas o enfermeiro diz que não. Cada um deles espera que o outro tenha arranjado preservativos. Nesse fim-de-semana, começaram a ter relações sexuais. Os dois estão demasiado embaraçados para contar o que aconteceu, então ignoram o assunto e avançam e têm relações sexuais sem usar o preservativo.
O Casal B precisa:
1
2
3
4
5
6

Casal C: Estes dois jovens querem ter relações sexuais. A rapariga diz ao namorado que trouxe preservativos, mas ele diz "Nem pensar... Esses são péssimos!" Ela tenta insistir, mas ele fica irritado, diz que ela está a agir como uma criança e pergunta se ela realmente o ama ou não. Ela acaba desistindo de discutir e eles têm relações sexuais sem o preservativo.

$\begin{array}{lllllll}\text { O Casal C precisa: } & 1 & 2 & 3 & 4 & 5 & 6\end{array}$




\section{soluções para habilitar as pessoas a usar o preservativo}

Casal D: Estas duas pessoas querem ter relações sexuais e concordaram em usar o preservativo. Mas quando chega o momento de usá-lo, o rapaz fica todo atrapalhado com o pacote do preservativo e perde a erecção. Desta vez, decidem não ter relações sexuais. Mas a vez seguinte que estão juntos, fica ansioso com a ideia de voltar a perder a sua erecção. Ele diz à namorada que os preservativos prejudicam o clima e, por isso, concordam em ter relações sexuais sem usar o preservativo.
O Casal D precisa:
2
3
4
5
6

Casal E: Estas duas pessoas decidiram ter relações sexuais. Os dois acham que é uma boa ideia usar o preservativo, mas receiam que o parceiro pense que são "porcos" se sugerirem o uso do preservativo. No fim, nenhum deles sabe como levantar a questão, então têm relações sexuais sem usar o preservativo.
O Casal E precisa:
1
2
3
4
5
6

Casal F: Este rapaz, que tem 16 anos, está numa quadrilha. Quer abandoná-la, mas isso é difícil e pode ser perigoso. Porém, a sua quadrilha deixa-o sair se ele for pai. O rapaz explica à namorada, que tem 15 anos, que se tiverem um bebé, isso poderia salvar a sua vida e que ele será um bom pai. Ela sente-se confusa e não sabe o que fazer. Quer terminar os estudos e não se sente pronta para ser mãe. Por outro lado, acha que deve ajudar o namorado. Têm relações sexuais sem usar o preservativo.
O Casal F precisa:
2
3
4
5
6

Casal G: Estas duas pessoas decidem ter relações sexuais. O rapaz pergunta se deviam usar protecção, mas a rapariga diz que acaba de ter o período menstrual, portanto não pode engravidar.
O Casal G precisa:
2
3
4
5
6

Casal H: Estas duas pessoas decidem ter relações sexuais. Discutem se devem usar o preservativo para os proteger contra o HIV, mas concordam que já saberiam se estivessem doentes. Por isso, avançam e têm relações sexuais sem usar o preservativo.
O Casal H precisa:
1
2
3
4
5
6

Casal I: Uma rapariga de 17 anos está a ter relações sexuais com um homem de 25 anos que lhe dá presentes, e por vezes dinheiro, para ajudá-la nas suas despesas. Há vezes em que ele usa o preservativo, mas desta vez não tem nenhum. Ela acha que devem esperar por uma outra ocasião, mas ele promete que estará tudo bem sem o preservativo. Ela já recebeu dinheiro dele esta semana, então acha que não deve recusar. Têm relações sexuais sem usar o preservativo.

O Casal I precisa:

1
3
5
6 


\section{chave de respostas para "soluções para habilitar as pessoas a usar o preservativo"}

NOTA PARA OS PROFESSORES: A lista a seguir identifica as principais "soluções" para o casal de cada história. Para qualquer das histórias, os seus alunos poderão sugerir mais soluções. Seja flexível ao responder, mas no mínimo procure garantir que as soluções adiante indicadas estejam incluídas nas respostas finais.

Casal A Solução 1 (informação sobre o uso correcto do preservativo)

Casal B Solução 4 (informação sobre onde obter preservativos); e:

Solução 3 (melhores habilidades de comunicação)

Casal C Solução 2 (maior igualdade e poder partilhado entre a rapariga e o rapaz); e:

Solução 3 (melhores habilidades de comunicação)

Casal D Solução 6 (um local seguro para o rapaz discutir a sua ansiedade em relação ao desempenho sexual)

Casal E Solução 3 (melhores habilidades de comunicação); e:

Solução 5 (uma ideia mais realista sobre o risco de HIV e de gravidez)

Casal F

Solução 2 (maior igualdade e poder partilhado entre a rapariga e o rapaz)

Casal G

Solução 5 (uma ideia mais realista do risco de engravidar)

Casal H

Solução 5 (uma ideia mais realista do risco de HIV)

Casal I

Solução 2 (maior igualdade e poder partilhado entre a rapariga e o rapaz) 


\section{etapas correctas do uso do preservativo}

NOTA AOS PROFESSORES: Prepare 16 cartões (flashcards). Em cada cartão, escreva uma etapa da lista a seguir. Não inclua o "número da etapa." (Os números são indicados a seguir como a sua chave de respostas). Lembre-se que a ordem das Etapas 1-5 é flexível.

\section{(Com muita antecedência)}

1 Discutir o sexo seguro com o seu parceiro.

2 Comprar preservativos (e lubrificante, se assim o desejar) ou identificar uma clínica ou outro centro da comunidade que os ofereça gratuitamente.

3 Manter os preservativos num local seco e fresco (não na carteira).

4 Verificar o prazo de validade do preservativo e se a data não expirou.

5 Praticar o uso do preservativo para que esteja à vontade ao usá-lo mais tarde.

(Imediatamente antes do acto sexual)

6 Realizar os preliminares. Os preliminares, que incluem tocar o clítoris, podem ajudar a lubrificar a vagina.

7 Abrir o preservativo com jeito, tendo o cuidado de não rasgá-lo (não usar os dentes!).

8 Quando o pénis está erecto... Apertar a ponta do preservativo e colocá-lo na ponta do pénis.

9 Segurar a ponta do preservativo e desenrolá-lo até que o pénis esteja totalmente coberto.

10 Se a vagina continuar seca, realizar mais preliminares ou molhar a parte exterior do preservativo com um lubrificante à base de água ou com saliva. Nunca usar Vaseline ${ }^{\circledR}$ ou outros produtos à base de óleo porque podem enfraquecer o preservativo e rasgar-se.

(Durante $o$ acto sexual)

11 Se o preservativo se rasgar, o homem deve retirar o pénis imediatamente. [Lembrar aos alunos sobre a contracepção de emergência se a ejaculação já tiver acontecido].

12 Após a ejaculação, enquanto o pénis ainda está erecto ...

13 Segurar a abertura do preservativo na base do pénis.

\section{(Imediatamente após o acto sexual)}

14 Segurando o preservativo na base do pénis, retirar suavemente o pénis.

15 Retirar o preservativo com cuidado sem deixar cair sémen segurando a sua borda.

16 Amarrar o preservativo ou embrulhá-lo com papel higiénico e deitar fora num local seguro. 


\section{iniciar uma conversa sobre sexo e protecção}

\section{DURAC̄ÃO:}

Etapas 1-3: 40 minutos

Etapas 4-10: 40 minutos

\section{MATERIAL:}

Quadro + giz

\section{PREPARAC̄ÃO:}

Rever e modificar os cenários consoante as necessidades (por exemplo, o casal pode estar noivo). Planificar o seu tempo com cuidado e garantir que a representação seja breve.

VISÃO GERAL: Os alunos praticam a forma de iniciar conversas sobre temas importantes ligados à segurança e saúde sexuais, que muitas vezes são ignorados. (Nota: Esta actividade tem alguma sobreposição com a actividade 38; os educadores poderão implementar uma ou as duas actividades para ensinar estas importantes habilidades.)

OBJECTIVOS: Permitir que os alunos pensem e pratiquem como iniciar e ter conversas sobre temas relacionados com o sexo e a segurança; fortalecer as habilidades de pensamento crítico.

\section{INSTRUÇÕES}

1 Introduza a actividade com base nas seguintes perguntas:

- Vamos praticar conversas sobre a segurança sexual. Para efeitos deste exercício, vamo-nos concentrar em conversas sobre a interacção heterossexual.

- É fácil falar sobre coisas relacionadas com o sexo? Porquê? O que pode facilitar as coisas?

2 Peça aos alunos que formem pares (de preferência masculino-feminino). Escreva os seguintes temas no quadro:

Ter ou não ter relações sexuais

Experiência sexual anterior

Infecções transmitidas sexualmente, HIV e SIDA

Uso de drogas anterior

Uso do preservativo

3 Explique:

- Nos vossos pares, vão praticar como iniciar conversas sobre assuntos difíceis, mas importantes. Para cada um dos tópicos no quadro, discutam como iniciar uma conversa com um possível parceiro sexual. Escrevam pelo menos uma maneira específica de iniciar a conversa.

- Decidam também em que momento deve ter lugar uma primeira conversa- quando se encontram? Depois do primeiro beijo? Quando já se encontram numa situação sexual? Lembremse que as pessoas não precisam falar tudo imediatamente.

4 Para cada tópico, peça a um grupo que partilhe as suas ideias; escreva as respostas no quadro. Perguntar:

- Alguém quer apresentar uma sugestão diferente? (Adicioná-las à lista.)

- Que ideias acham que resultariam e porquê? Existem algumas sugestões que acham que podem não ser uma boa abordagem? Porquê?

- Quando numa relação é que esta primeira conversa deve acontecer? Porquê? 
5 Depois de analisarem os cinco tópicos, perguntar:

- O que pode tornar mais fácil iniciar este tipo de conversas?

- Agora vamos praticar pensar como estas conversas aconteceriam na vida real.

\section{Explique:}

- A primeira pessoa deve começar a conversa; porém, a segunda pessoa deve dificultar a conversa. A segunda pessoa pode mostrar-se embaraçada, pode discordar ou tentar evitar a conversa.

- A tarefa da primeira pessoa é tentar manter a conversa a decorrer, pelo menos um pouco.

7 Peça a dois voluntários que representem uma conversa sobre o primeiro tópico (ter ou não ter relações sexuais). Explicar:

- Arranjem nomes para os vossos personagens e tentem ser realistas.

- Aqui está o vosso cenário [Introduzir os novos nomes ao ler o seguinte cenário]:

- "Ali e Lia namoram há já algum tempo e começaram a sentir-se próximos fisicamente. Ainda não tiveram relações sexuais. Nenhum deles está certo sobre o comportamento sexual ou de consumo de drogas do outro antes de começarem a namorar. Ali acredita que podem envolver-se mais sexualmente e está mesmo preocupado com o HIV. Neste momento, estão a passear a pé."

- Todos os outros devem tomar notas sobre como os dois voluntários estão a comunicar.

8 Dinamize uma breve discussão com base nas seguintes perguntas:

- O que correu bem? O que podia ter sido tratado de maneira diferente?
- A conversa foi realista?

- Têm algum conselho para Ali ou Lia?

9 Repita as Etapas 6-8 para o maior número de cenários a seguir que o tempo permitir:

- Anjali começa uma conversa com Mo sobre se devem, ou não, ter relações sexuais. Podem, ou não, chegar a acordo sobre o que fazer.

- Carlo inicia uma conversa com Mar sobre a sua anterior experiência sexual e de consumo de drogas;

- Henry e Mia já conversaram e acham que querem ter relações sexuais. Henry inicia uma conversa com Mia sobre o uso do preservativo. [Instruir Henry em privado que ele não quer ter relações sexuais sem o preservativo e instruir Mia em privado que ela não acha que seja necessário usar o preservativo].

10 Encerre a actividade com as seguinte perguntas, escrevendo as respostas principais no quadro:

- Antes de terem uma conversa como esta, em que devem pensar sobre vós próprios? [Sondar o seguinte: como se sentem, o que querem, o que querem dizer].

- Quais são algumas dicas de uma comunicação bem-sucedida?

- Quais são algumas dicas para dizer "não" com respeito?

- Que direitos tem cada pessoa? [Sondar o seguinte: O direito de manifestar a sua opinião, o direito de dizer não, o direito de proteger a sua própria saúde].

- De quem é a responsabilidade de iniciar tais conversas num relacionamento? Porquê? 


\section{SIDA: aprender dos outros}

\section{DURAC̣̃̃O:}

Etapa 1: 10 minutos (no dia anterior) Etapas 2-4: 40 minutos (flexível)

\section{MATERIAL:}

Quadro + giz; ficha do aluno (se não houver um orador).

\section{PREPARAC̣ÃO:}

Convidar 1-2 oradores que sejam seropositivos (o ideal seria um homem e uma mulher). Se tal não for possível, convidar um membro de um grupo que trabalha na área do HIV e SIDA, ou alguém que cuide de pessoas com HIV. Pedir ao orador que conte a sua história pessoal. Informar o orador sobre a idade dos alunos e sobre o seu conhecimento prévio do SIDA, bem como o tempo atribuído à apresentação / perguntas. Pode pedir ao orador que discuta os

seguintes aspectos:

Enterarse/conhecer o estado em relação ao HIV

Divulgar o estado em relação ao HIV

Estigma / discriminação

Obter apoio

Cuidados de saúde e tratamento

Vida quotidiana

Como viver com o HIV é diferente nos homens e nas mulheres

Fazer a Etapa 1 antes da visita do orador.

VISÃO GERAL: Os alunos ouvem a história de uma pessoa seropositiva.

OBJECTIVOS: Permitir que os alunos entendam e sintam compaixão pelas pessoas que vivem com o HIV e SIDA.

\section{INSTRUÇÕES}

\section{Antes da visita do orador}

1 Informe os alunos que na próxima sessão, um ou mais oradores convidados vão partilhar as suas experiências pessoais de vida com o HIV. Perguntar: "O que gostariam de aprender?" "Que receios têm?" Responda a quaisquer receios revendo a informação sobre o HIV consoante as necessidades. Lembre aos alunos sobre as regras de base; se não tiver nenhumas regras, peçalhes que produzam algumas regras de comportamento correcto para com um orador convidado.

Actividade alternativa: Se não for possível convidar um orador na sua comunidade, poderá usar a ficha "Histórias Verídicas." Peça aos alunos que atribuam nomes locais às pessoas das histórias e que as leiam em voz alta. Dê-lhes tempo para fazerem perguntas e em seguida avance com as Etapas 3 e 4.

\section{$\mathrm{Na}$ altura da visita do orador}

2 Apresente e agradeça o orador convidado. Mencione quanto tempo o orador irá falar.

3 Reserve tempo para os alunos fazerem perguntas. Agradeça o orador e diga adeus.

Um pouco depois de o orador partir

4 Dinamizar uma discussão com base nas seguintes perguntas:

- Que sentimentos ou impressões tiveram durante a(s) apresentação(ões)?

- Que partes da(s) apresentação(ões) foram mais significativas ou mais surpreendentes para vocês?

- O que aprenderam sobre como é ter HIV?

- Que sentimentos o orador disse ter?

- Que mitos ou estereótipos enfrentou?

- Têm mais alguma pergunta?

- Qual é a coisa mais importante que aprenderam ou viveram hoje? De que maneira o que aprenderam fará diferença em vocês? [Sondar o seguinte: Sentirei e passarei a comportar-me de maneira diferente em relação às pessoas que vivem com o HIV e SIDA. Terei mais cuidado em relação à prevenção da transmissão do HIV]. 


\section{histórias verídicas (para usar se não houver orador)}

HISTÓRIA DE MWENZI: Sou uma mulher zambiana de 22 anos e tenho HIV, o vírus que causa o SIDA. Quando era criança, perdi os meus pais por causa do SIDA e fui criada pela minha irmã mais velha. Quando tinha 19 anos, engravidei e comecei a receber cuidados pré-natais no centro de saúde local, onde fiz o teste do HIV. Quando me disseram que o resultado era positivo, não quis acreditar. Sentia-me bem de saúde e tinha um aspecto saudável. Não parecia real, eu não queria morrer. Quando disse ao meu namorado, ele riu-se. E disse, "Não é possível, tu não pareces doente. Estão a tentar assustar-te." Mas depois ele foi fazer o teste e soube que também estava infectado. Felizmente, a minha irmã tem sido muito carinhosa. Ajuda a pagar os meus medicamentos e dá-me apoio de muitas outras formas. Decidi que não vou deixar que o HIV seja um obstáculo total na minha vida. Se eu puder escolher, vou lutar contra esta doença. Ainda bem que fiz o teste porque assim pude iniciar o tratamento anti-retroviral, que me mantém saudável e que protegeu o meu bebé de nascer com o vírus do SIDA. A parte mais difícil é quando as outras pessoas me tratam mal por causa da minha doença. Não sei durante quanto tempo mais estarei saudável, mas estou a viver a vida plenamente. Sou uma boa mãe. E tenho um trabalho: ensinar aos outros jovens sobre como se devem proteger e aos seus parceiros de contrair esta doença.
HISTÓRIA DE BRETT: Aos 18 anos, eu era um garoto esperto e inteligente, com um corte de cabelo "punk", tinha aulas de dia e à noite frequentava os bares no Smart Bar e no Metro. Dois anos mais tarde, eu estava parado à porta do Jewel, numa cabina telefónica, quando soube que tinha o vírus que causa o SIDA. Fiquei chocado. Mas o que me faltava na saúde, eu compensava na juventude. Eu era corajoso e idealista. Acreditava que nós - pacientes, médicos, cientistas e pesquisadores - se realmente tivermos a intenção, conseguiremos curar o SIDA. Sei que soa a idealista, mas na altura precisávamos de inspiração. O idealismo é o que me manteve vivo quando havia pouca esperança. Sempre quis escrever. Depois do meu diagnóstico, sabia exactamente o que queria escrever e mergulhei no tema. Consegui juntar dinheiro suficiente para lançar uma revista chamada Plus Voice. A minha visão era uma revista sobre o estilo de vida destinada às pessoas com o vírus, a primeira do seu género. Por vezes sintome exausto, mas a escrita e os meus amigos fazem-me continuar. Sou seropositivo toda a minha vida adulta. Claro que ainda não temos cura do SIDA, mas agora temos medicamentos excelentes para controlar o vírus. E está a melhorar de ano para ano. Mas este novo medicamento não é fácil não. Os seus efeitos são difíceis no corpo e certamente não nos dá livre-trânsito para não sermos saudáveis de outras maneiras. Usar o cinto de segurança. Não fumar. Beber moderadamente. Obter apoio mental quando necessário. Fazer exercício. Usar sempre, sempre o preservativo. E ser rigorosamente honesto para consigo próprio em relação a todos os aspectos da sua vida. [Adaptado com autorização da Test Positive Aware Network <www.tpan.com>]. 


\section{o que têm para dizer? o que gostariam de saber?}

actividade

\section{DURACÃO:}

Etapas 1-5: 45 minutos

Etapas 5-6: 45 minutos

\section{MATERIAL: \\ Quadro + giz}

\section{PREPARAC̄̃̃:}

Pensar em "perguntas abertas" (não perguntas do tipo sim / não) ao sondar respostas mais profundas na Etapa 1. Se for possível, obter informação sobre a prevalência do HIV no seu contexto. Esta actividade pode suscitar sentimentos fortes nos estudantes; pensar como apoiar devidamente os estudantes.

Respeitar a privacidade de todos e não exigir que ninguém leia a sua história em voz alta.
VISÃO GERAL: Os estudantes discutem qual o grau de responsabilidade que as pessoas têm de revelar o seu estado em relação ao HIV a um parceiro sexual. Analisam o equilíbrio complexo entre o direito à privacidade e o direito de a pessoa se proteger do mal. Exploram os seus sentimentos em relação a este dilema através da escrita criativa. (Nota: Antes da actividade, os estudantes devem ter obtido informação básica sobre os direitos humanos, consentimento informado e HIV e SIDA.)

OBJECTIVOS: Permitir que os estudantes pensem de maneira crítica sobre que responsabilidade ou obrigação as pessoas têm de revelar o seu estado em relação ao HIV a um parceiro sexual.

\section{INSTRUC̣ÕES}

1 Apresente a actividade com base nas perguntas a seguir. [Registar as respostas dos alunos no quadro].

- Hoje vamos discutir um assunto delicado e complicado: se as pessoas são obrigadas a revelar o seu estado em relação ao HIV a um parceiro sexual.

- Acham que as pessoas que sabem que são seropositivas dizem sempre aos seus parceiros sexuais?

- Quais são algumas das razões que fazem com que uma pessoa possa não revelar o seu estado ao seu parceiro? [Sondar o seguinte: Proteger a sua privacidade; receio de estigma, abandono e discriminação].

- Quais são algumas das razões que fazem com que algumas pessoas não procurem fazer o teste do HIV? [Sondar o seguinte: Têm receio de o resultado do teste ser positivo (terem HIV); sentemse embaraçadas em ir fazer o teste a uma clínica; não têm conhecimento da existência de locais onde possam ir fazer o teste gratuitamente; sentem-se saudáveis e têm um aspecto saudável e, portanto, não acreditam que possam estar infectadas; o horário dos testes é incompatível com o da escola ou do trabalho; não confiam que o resultado será mantido em sigilo].

- Quais são algumas das razões que devem levar as pessoas a fazer o teste do HIV? [Sondar o seguinte: Se o teste for negativo, sentir-se-ão aliviadas, se o teste for positivo, podem iniciar o tratamento; proteger os parceiros de infecção no futuro; informar os parceiros actuais e do passado para que essas pessoas possam fazer o teste].

2 Peça aos alunos que abram os seus cadernos. Explicar:

- Tivemos a oportunidade de pensar em algumas das razões que fazem com que as pessoas possam optar por não fazer o teste ou revelar aos seus parceiros o seu estado em relação ao HIV. A vossa tarefa é escrever uma breve história que aprofunde ainda mais este tema. A história não deve ter mais do que três páginas.

- Qual deve ser o tema da vossa história? A vossa história pode tratar de alguém que escolha não fazer o teste. Ou pode dizer respeito a uma pessoa que tenha contraído o HIV de um parceiro e não 
divulgou que era seropositivo. Ou pode ainda ser sobre alguém que saiba que está infectado pelo HIV e revela ao seu parceiro.

- Que questões e sentimentos devem ser explorados na vossa história? A vossa história deve conter alguma tensão. Mostrem como o vosso personagem chegou a uma decisão, como se sentiu em relação a essa decisão e o que aconteceu (como a decisão afectou a vida do vosso personagem e como afectou as vidas das outras pessoas). Pensem em como o personagem se sente (com medo? apoiado? só? aliviado? arrependido? amado? grato? amargo?).

- A história deve ser factual ou fictícia? A história pode ser totalmente inventada, ou podem baseá-la na vossa própria experiência ou na situação de alguém que conheçam. Mas é importante não usar o nome verdadeiro da pessoa. Palavra final: Estas histórias não devem ser longas, mas devem ser sérias. Esta é uma tarefa profunda, e não de humor. A vossa história pode ser concluída fora da aula, se não tiverem tempo de terminar.

3 Peça aos alunos que comecem a pensar e a escrever as suas histórias. Se tiver planos de pedir aos alunos que leiam as suas histórias, diga-lhes antes de começarem a escrever. Informe que podem falar consigo se tiverem dificuldades em inventar uma história. [Pode sugerir: Um rapaz tem medo de fazer o teste porque perdeu os dois pais por causa do SIDA; uma rapariga tem receio de dizer ao seu parceiro que é seropositiva em consequência de uma violação porque o namorado acredita que ela era virgem antes de se conhecerem].

4 Recolha as histórias ou peça aos alunos que as terminem como trabalho de casa. No entanto, antes da segunda sessão (em que os alunos lêem o seu trabalho em voz alta), leia cada história para verificar se elas são apropriadas e anónimas.

5 Convide os alunos a ler as suas histórias. (Não é necessário ler todas elas.)

6 Encerre a actividade discutindo as seguintes perguntas:

- Alguém viu este dilema de maneira diferente depois de ouvir a história de um colega ou de descrever a sua própria história? Em que medida é que acham que as vossas atitudes ou sentimentos mudaram? [Sondar: Acham que fazer o teste do HIV é mais difícil ou mais fácil do que pensavam que era? Revelar a um parceiro é mais ou menos importante do que pensavam que era? Acham que responderiam de maneira diferente a um parceiro romântico ou sexual que vos dissesse que é seropositivo?]

- A questão de revelar o estado em relação ao HIV é sempre uma questão clara e evidente?

- Como nos certificamos de que tomamos a atitude o mais honesta possível com os nossos parceiros e connosco próprios de modo a garantir a nossa própria boa saúde e a deles?

- A testagem e aconselhamento opcional e anónimo devem ser oferecidos ou promovidos activamente sempre que as pessoas se dirigem a uma clínica? Ou os profissionais de saúde devem fazer o teste do HIV apenas quando alguém pede especificamente para o fazer?

- Alguém tem comentários finais? [Procurar encerrar esta sessão com um comentário sobre o facto de a pandemia do SIDA exigir que todos nós sejamos honestos, compreensivos, autodisciplinados, corajosos e optimistas]. 


\section{jogos sobre o conhecimento de contraceptivos}

\section{DURAC̣ÃO:}

45 minutos

\section{MATERIAL:}

Quadro + giz; cópias das palavras cruzadas; e da ficha "Lista de Métodos Contraceptivos";

tiras de papel com nomes de contraceptivos; um saco; quatro exemplares da ficha técnica sobre Métodos Contraceptivos em DIRECTRIZES ou outro texto fiável; se possível, um relógio (para cronometrar intervalos de 30 segundos); um pequeno prémio para a equipa vencedora.

\section{PREPARAC̄̃O:}

Fotocopiar as palavras cruzadas (com ou sem as respostas). Rever a lista de métodos contraceptivos; riscar qualquer método que não seja tratado. Antes desta sessão, os alunos devem aprender sobre estes métodos que se encontram na sua lista. Escrever o nome de cada método da lista numa tira de papel separada. Dobrar as tiras ao meio e colocá-las no saco. Ler a nota da Etapa 3 e planificar em conformidade. Fazer uma revisão da informação sobre contraceptivos.
VISÃO GERAL: Os alunos fazem a revisão da informação sobre métodos contraceptivos através de palavras cruzadas e de um jogo. Discutem a responsabilidade mútua pela contracepção. (Nota: Esta actividade pode ser de introdução ou de revisão dos métodos contraceptivos.)

OBJECTIVOS: Rever e fortalecer os conhecimentos dos alunos sobre métodos contraceptivos; fortalecer as habilidades de escrita.

\section{INSTRUC̣ÕES}

Trabalho de Casa (a ser dado antes desta actividade): Preencher as palavras cruzadas "Métodos Contraceptivos". (Distribuir palavras cruzadas em branco por cada estudante.)

\section{Continuar a Etapa 1 no dia seguinte.}

1 Analisar as respostas às palavras cruzadas em grupo. Responder a quaisquer perguntas.

2 Explique aos alunos que vão fazer um jogo chamado "Cinco Perguntas," que irá testar o seu conhecimento de diferentes métodos contraceptivos. Formar três equipas e explicar:

- Este saco tem tiras de papel e cada tira tem o nome de um método contraceptivo diferente. A Equipa 1 deve começar tirando uma tira de papel.

- As Equipas 2 e 3 devem tentar adivinhar que método contraceptivo se encontra no papel que a Equipa 1 tem. Para descobrirem, só podem fazer perguntas cuja resposta seja "sim" ou "não". [Esclarecer para que todos entendam o que são perguntas "sim" e "não"]. Primeiro, a Equipa 2 deve fazer uma pergunta à Equipa 1.
3 Explique as regras. [Nota: Se os seus alunos tiverem algum conhecimento prévio sobre métodos contraceptivos, podem usar a dica "sim" ou "não" para ajudá-los a identificar a resposta certa (método certo). Se não tiverem sequer conhecimentos básicos sobre contraceptivos, cada equipa pode necessitar da sua própria ficha técnica para usar as dicas com eficácia].

- Para se certificar de que são dadas respostas certas às perguntas, a equipa que responde pode consultar a ficha técnica sobre métodos contraceptivos. [Levantar a ficha técnica]. Lembrem-se que têm apenas 30 segundos para responder "sim" ou "não." Podem discutir em voz baixa a resposta na equipa antes de responderem. Devem mostrar-me o que está na vossa tira de papel para que eu possa corrigir qualquer informação errada. Se derem informação errada sobre o vosso método, a vossa equipa perde meio ponto. E lembrem-se que podem responder dizendo apenas “sim” ou "não." Por último, indiquem alguém na vossa equipa para controlar a quantas perguntas respondem e anunciar quando tiverem sido respondidas cinco perguntas sem que o método tenha sido correctamente identificado. 
- Depois de ouvir a resposta da Equipa 1 à primeira pergunta da Equipa 2, a Equipa 2 pode tentar adivinhar o nome do método contraceptivo. Se a Equipa 2 responder incorrectamente (ou se preferir não responder), a Equipa 3 pode fazer uma pergunta. As Equipas 2 e 3 farão as perguntas alternadamente até que uma delas dê a resposta certa (ganhando um ponto), ou até que as cinco perguntas tenham sido feitas.

- Se depois das cinco perguntas terem sido feitas nenhuma das equipas acertar no método, a Equipa 1 anuncia a resposta certa, esclarece informação importante relacionada com o método e ganha o ponto.

4 Explique como o jogo deve decorrer.

- Em seguida, a Equipa 2 tira um pedaço de papel e as Equipas 1 e 3 fazem as perguntas. Vamos proceder desta maneira até o tempo se esgotar, ou até que todos os pedaços de papel tenham sido tirados.

- Todos entendem as regras?

[Demonstrar com uma tira de papel (método), caso seja necessário].

5 Designar um aluno para controlar o tempo, ou seja, os 30 segundos permitidos para responder a cada pergunta. Indicar um outro aluno para registar a pontuação, marcando os pontos no quadro.
6 Peça à Equipa 1 que escolha uma tira de papel e dê à equipa a ficha técnica sobre contraceptivos. Procure verificar cada tira de papel que é retirada; mantenha uma cópia da ficha técnica sobre os métodos contraceptivos para referência rápida de modo a poder corrigir qualquer informação incorrecta.

7 Assim que a resposta certa for dada, ou que as cinco perguntas tiverem sido respondidas, parem. Atribua o ponto à equipa vencedora e peça à Equipa 2 que escolha uma tira de papel. Peça às equipas que continuem a jogar alternadamente durante cerca de 20 minutos, ou até dez minutos antes do fim da sessão.

8 Declare uma equipa vencedora e ofereça-lhe o prémio, se tiver.

9 Reserve cinco a 10 minutos para discutir os seguintes aspectos:

- O que aprenderam sobre um método contraceptivo hoje que não sabiam e que acharam interessante?

- [A pergunta a seguir pode ser dada como trabalho de casa; ver abaixo]. Todos devem saber sobre a existência de contracepção? De quem é a responsabilidade de proteger da gravidez indesejada?

Trabalho de Casa: Escrever um parágrafo em resposta às seguintes perguntas: Todos devem saber sobre a existência de contracepção? De quem é a responsabilidade de proteger da gravidez indesejada? Podem manifestar a vossa opinião directamente ou responder sob a forma de uma história. 


\section{palavras cruzadas sobre métodos contraceptivos}

Ler cada dica e preencher com a resposta certa. A resposta deve caber no número correcto de espaços. Nos casos em que uma resposta vertical se cruze com uma resposta horizontal, essas palavras partilham um espaço com a mesma letra.

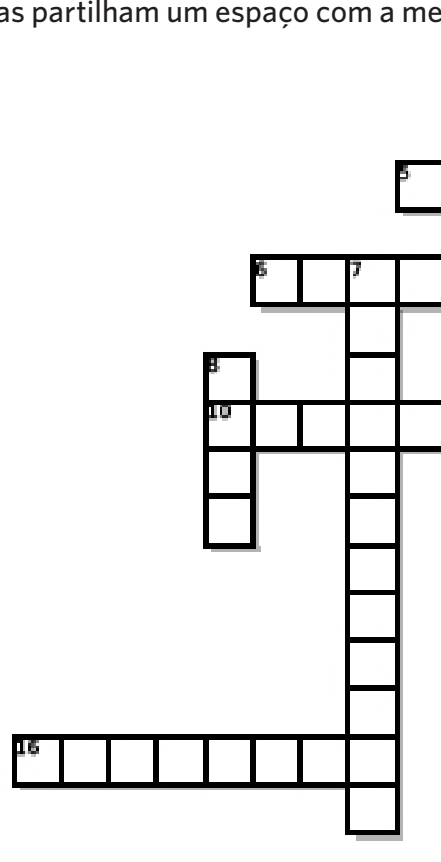

Horizontal

2 Procedimento cirúrgico que previne a libertação de esperma do homem

4 Um invólucro ou bolsa que uma mulher ou rapariga introduz na vagina para impedir a entrada de esperma no seu corpo (duas palavras)

5 Uma mulher ou rapariga consegue dizer quando está no período fértil com base na quantidade e consistência do seu _________(duas palavras)

6 Um homem ou rapaz usa no pénis durante o acto sexual; previne a gravidez e protege das ITS/HIV (duas palavras)

$\cdot e \mid n ! ! 9 \forall \cdot \varepsilon$

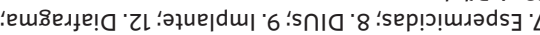

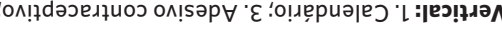

؛

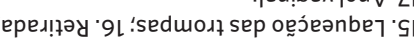

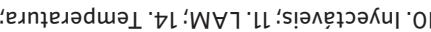

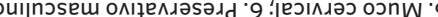

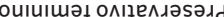

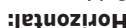

seisodsay әр әмечว
10 Injecções dadas periodicamente a uma mulher ou rapariga para impedir a ovulação e tornar o muco cervical espesso (plural)

11 Método natural resultante da amamentação (abreviatura)

14 O método ______ implica que uma mulher ou rapariga use o termómetro para saber quando não está no período fértil

15 Uma operação em que as Trompas de Falópio da mulher são cortadas ou atadas para impedir que o ovulo e o esperma se encontrem (duas palavras)
16 Retirar o pénis da vagina antes da ejaculação

17 Um dispositivo com a forma de argola inserido por uma mulher ou rapariga na sua vagina; não protege contra as ITS/HIV (duas palavras)

Vertica

1 Uma mulher ou rapariga consegue calcular quando está no período fértil registando os seus ciclos menstruais num

3 Uma mulher ou rapariga aplica à sua pele como adesivo; não protege contra as ITS/HIV (duas palavras)

7 Várias substâncias introduzidas na vagina para matar o esperma (plural)

8 Introduzido no útero, muitas vezes com a forma de um T (abreviatura, plural)

9 Uma pequena haste introduzida no braço da mulher ou da rapariga

12 Uma capa de borracha que é enchida com espermicida e introduzida na vagina, cobrindo o colo do útero

13 Uma mulher ou rapariga toma diariamente para evitar a gravidez (nome comum, duas palavras) 


\section{lista de métodos contraceptivos usados em todo o mundo}

Métodos temporários, controlados pela utilizadora ou utilizador (que impedem que o esperma chegue até ao óvulo) Preservativo masculino

Preservativo feminino

Diafragma

Capa cervical

Espermicidas

Métodos que funcionam dentro do sistema do corpo

De curta duração, controlados pela utilizadora

Contracepção oral (pílula)

Contracepção de emergência

De longa duração

Injectáveis (Depo-provera)

Anel vaginal hormonal

Adesivo hormonal

Implante hormonal

Dispositivo intra-uterino (DIU)

Métodos naturais (que requerem comportamentos específicos e que se entenda o corpo)

Método de amenorreia lactacional (lactational amenorrhea method - LAM)

Retirada (Coito Interrompido)

Método do muco cervical de consciência da fertilidade

Método de temperatura de consciência da fertilidade

Método do Calendário, Dias Padrão, ou "Cycle Beads" de consciência da fertilidade (chamado método do ritmo)

Abstinência

Relações sexuais exteriores (jogos sexuais sem acto sexual)

\section{Métodos cirúrgicos permanentes}

Laqueação das trompas (ou outros métodos de esterilização feminina)

Vasectomia 


\section{pôr-se no lugar dela: a decisão de interromper uma gravidez}

VISÃO GERAL: Os alunos lêem estudos de caso e discutem os motivos que levam as mulheres a fazer o aborto.

OBJECTIVOS: Permitir que os alunos discutam três motivos que levam as mulheres e as raparigas a optar por fazer o aborto; fortalecer as habilidades de pensamento analítico e de diálogo.

\section{INSTRUÇÕES}

60 minutos (podem ser divididos em duas sessões)

\section{MATERIAL:}

Quadro + giz; um estudo de caso da ficha "Casos de Aborto" para cada grupo (ou uma cópia de todos os casos e atribuir um caso a cada grupo); o volume de DIRECTRIZES de Um Só Programa (o volume que acompanha o presente livro, acessível em <www.itsallone.org>), ou uma fotocópia da secção sobre a gravidez indesejada e o aborto da Unidade 7 desse volume.

\section{PREPARAC̣ÃO:}

Rever o material acima mencionado para se informar da lista completa de razões que fazem com que as mulheres optem por fazer o aborto. Rever e, se for necessário, alterar os estudos de caso para torná-los apropriados sob o ponto de vista cultural. Verificar se os casos reflectem as várias razões para escolher fazer o aborto. Familiarizarse com a legislação local sobre o aborto (especialmente no que diz respeito aos jovens) e o apoio à criança.

1 Inicie a actividade com as seguintes perguntas:

- Hoje vamos discutir decisões complicadas que tomamos na vida. Pensem numa altura em que vocês - ou alguém próximo - tiveram que tomar uma decisão difícil que outros possam não ter aprovado. [Esperar um instante].

- Como se sentiram? Vocês (ou a pessoa em quem estão a pensar) tiveram apoio?

- Se não, como é que isso afectou a decisão e como se sentiram?

- Para milhões de mulheres e raparigas, ver-se a braços com uma gravidez indesejada torna-se o momento de decisão. Para alguns, esta decisão é simples e directa, enquanto para outros é difícil e complexa.

- Hoje vamos discutir a decisão de fazer o aborto. Não vamos discutir se o aborto está certo ou errado. Vamos considerar as razões que estão por detrás dessa decisão para tentar entender por que razão alguns optam pelo aborto.

- Que escolhas uma rapariga ou uma mulher tem quando engravida? [Sondar o seguinte: Ter o bebé e criá-lo; dar o bebé para adopção; ou pôr termo à gravidez].
2 Divida os alunos em pequenos grupos de quatro ou cinco. Dê a cada grupo um estudo de caso e peça que leiam, preencham o nome da pessoa que conta a história e posteriormente discutam as seguintes questões [escrevê-las no quadro]:

- Porque razão esta rapariga fez o aborto?

- Que papel tiveram outras pessoas na sua decisão? [Enquanto trabalham, escrever no quadro "Razões que levam as raparigas e as mulheres a optar pelo aborto:"]

3 Volte a juntar o grupo. Peça ao primeiro grupo que leia o seu estudo de caso e dê cinco a sete minutos para discutir as seguintes questões:

- Porque razão esta rapariga optou por fazer o aborto?

- Todos concordam que estas foram as suas razões? Havia outras razões? [Usando as perguntas, sondar as outras razões que são relevantes para este caso].

- Que papel outras pessoas (um parceiro, familiares, amigos ou outros) tiveram na sua decisão, seja directamente ou na sua mente?

- Mais alguém quer comentar? 
4 Repita este procedimento para cada caso. Atribua sete minutos para cada caso.

5 Reserve 10-15 minutos para analisar as questões que se seguem abaixo:

- Na vossa opinião, estas são razões (no quadro) que levam as mulheres jovens a fazer o aborto? Que outras razões conseguem encontrar que levam as mulheres a fazer o aborto? [Acrescentá-las à lista que está no quadro].

- Em todo o mundo, a maioria das mulheres que pratica o aborto são casadas. Conseguem pensar em algumas situações em que uma mulher casada pode optar por fazer o aborto?

- Em alguns países, o aborto é feito em várias circunstâncias, enquanto noutros países é legalmente restringido (ou é permitido apenas em algumas circunstâncias).

- Porque razão as mulheres e as raparigas fazem o aborto, mesmo quando o procedimento é ilegal e pode não oferecer segurança?
Trabalho de Casa: Seleccionar uma das citações que se segue:

Quando julga uma outra pessoa, você não define essa pessoa. Você define-se a si próprio. — Wayne Dyer

Nunca podemos julgar a vida dos outros, porque cada pessoa só conhece a sua própria dor e renúncia. Uma coisa é a pessoa sentir que está no caminho certo, outra coisa é pensar que o seu caminho é o único.

— Paulo Coelho

Lembrem-se que sou Humano. Antes de me julgarem ou de decidirem o que vão fazer comigo, ponham-se um pouco no meu lugar. Se o fizerem, acho que constatarão com maior compreensão que nos podemos encontrar no meio e fazer o resto da caminhada juntos.

— Eric Harvey e Steve Ventura

Gostaria de satisfazer a todos se pudesse; mas ao tentar satisfazer a todos, acabarei por não satisfazer a ninguém. Por isso, cheguei à conclusão que a melhor maneira é a pessoa satisfazer a sua própria consciência e deixar que o mundo forme o seu juízo próprio, favorável ou não.

$$
\text { - Mohandas K. Gandhi }
$$

Em seguida, copiar a citação e responder às seguintes perguntas:

- Como se sente após a leitura desta citação?

- Concorda ou não com o autor?

- De que forma o significado desta citação se relaciona com a situação de uma rapariga que opte por pôr termo a uma gravidez indesejada? 


\section{casos de aborto}

\section{FICHA DO GRUPO 1}

O meu nome é Eu e o meu namorado Lu temos 22 anos e namoramos há dois. Eu uso a pílula, embora me tenha esquecido de tomar umas quantas vezes no mês passado. Depois descobri que estava grávida. Acabo de começar um novo emprego, que adoro, mas ainda não paga lá muito bem.

Realmente gosto da minha vida tal como ela é e não quero ter um filho. Fui a uma clínica de planeamento familiar e fui aconselhada por uma enfermeira que insistiu energicamente que eu me casasse e tivesse o bebé. Lu concorda com a enfermeira porque acha que um dia hei-de querer ser mãe, então porque não agora? Estou transtornada porque sinto que estou a ser pressionada a ter um filho que eu não quero. Decidi ir a um sítio onde ouvi dizer que havia um médico que faz abortos sem fazer muitas perguntas.

\section{FICHA DO GRUPO 2}

O meu nome é Tenho 20 anos e fui a primeira pessoa da minha aldeia a ser aceite na universidade da cidade capital. A minha família, os meus amigos e vizinhos têm uma grande esperança de que o meu sucesso será o início de uma mudança real na comunidade. Pouco depois de iniciar as aulas, comecei a namorar com um outro estudante e ao fim de alguns meses, começamos a ter relações sexuais. Usámos o preservativo na maior parte das vezes, mas de vez em quando vimo-nos embrenhados na excitação e não usámos. Quando descobri que estava grávida, procurei conversar com o meu namorado sobre o que devíamos fazer, mas de repente ele tornouse distante e indisponível. Soube de uma amiga comum que ele achava que eu estava a tentar forçá-lo a casar-se comigo. Eu nem sequer quero me casar, mas também não quero ser uma mãe solteira na minha idade. Quero ter a oportunidade de terminar os meus estudos e de realizar os meus sonhos. Gostaria de ter recorrido à minha família para ter apoio, mas receava que se sentissem desiludidos comigo e eu não queria decepcioná-los. Então decidi não dizer a ninguém e usei o valor do meu subsídio para despesas pessoais para fazer o aborto. 


\section{casos de aborto}

\section{FICHA DO GRUPO 3}

O meu nome é . Sou um rapaz de 17 anos. Quando descobri que a minha namorada estava grávida, pensei “O quê? Ah não!” Os meus sentimentos eram um misto de choque, medo, preocupação e espanto. Uma pequena parte de mim até se sentiu um pouco orgulhosa por saber que eu era fértil. Eventualmente tive que lidar com o problema: "E agora - paternidade, adopção, aborto?" Eu e a minha namorada ainda estamos a estudar e sabemos que somos demasiado jovens para sermos pais. Achámos que a melhor decisão era fazer o aborto. Um amigo recomendou uma clínica e fomos juntos. O pessoal da clínica explicou exactamente o que ia acontecer. Antes de deixarmos a clínica, falaramnos da contracepção e deram-nos uma caixa de preservativos. Tive que enfrentar muitas das minhas próprias emoções, mas sinto-me orgulhoso por ter ajudado a minha namorada nesta decisão difícil.

\section{FICHA DO GRUPO 4}

O meu nome é . Tenho 15 anos e vivo com a minha grande família alargada. Todos os anos recebemos a visita da minha tia, do meu tio e do meu primo, que agora tem 18 anos. Um dia, numa altura em que todos estavam fora de casa, ele perguntou-me se me podia tocar e queria que eu fizesse o mesmo com ele. Isto pareceu-me estranho e realmente não gostei nada da ideia, mas ele é o meu primo mais velho e eu não queria aborrecê-lo. Quando começou a despir-me e veio para cima de mim, fiquei com medo e tentei afastá-lo, mas ele era demasiado forte e violoume. Quando descobri que estava grávida, fiquei muito assustada. Queria pedir ajuda à minha mãe, mas tinha muita vergonha de explicar o que tinha acontecido. Finalmente arranjei coragem e contei à minha mãe. Ela levou-me imediatamente para fazer o aborto e recusou-se pura e simplesmente a discutir o assunto. Fiquei aliviada por já não estar grávida, mas gostaria de ter podido conversar com alguém quando passei por esta experiência difícil. 


\section{inspire-se! criando a mudança}

VISÃO GERAL: Os alunos seleccionam uma citação que os inspire e exploram o que significaria aplicar a mensagem da citação nas suas próprias vidas.

OBJECTIVOS: Aumentar a motivação e a confiança dos alunos para mudarem o mundo em que vivem.

\section{DURAC̣ÃO:}

60-90 minutos, dependendo do número de citações

seleccionadas.

\section{MATERIAL:}

Quadro + giz; ficha de duas páginas "Citações sobre a Justiça Social e o Activismo."

\section{PREPARAC̣ÃO:}

Rever as citações e eliminar qualquer que não seja adequada ao seu contexto. Poderão ser acrescentadas outras citações do seu próprio país ou região. Ajustar o número de citações (e de declamações dos alunos) de acordo com o tempo previsto. Fazer cópias das citações que serão usadas ou escrevê-las no quadro.

\section{INSTRUC̣ÕES}

1 Explique:

- Hoje vamos explorar o que significa trabalhar em prol da justiça social ou mudar o mundo em que vivemos, mesmo que seja de uma maneira ínfima. Vamos analisar uma série de citações de pessoas que fizeram a diferença através dos seus próprios esforços.

- Leiam a lista e seleccionem a citação que mais vos inspira. A seguir, nos vossos cadernos e na parte de cima da página, copiem a vossa citação (juntamente com o nome da pessoa a quem a mesma é atribuída).

- Pensem no significado da vossa citação. Escrevam uma resposta de pelo menos três parágrafos. $\mathrm{O}$ primeiro parágrafo deve explicar qual pensam que é a mensagem contida na citação. O segundo parágrafo deve abordar as razões que a tornam significativa para vocês e por que a escolheram. No último parágrafo, analisem quais seriam as implicações de aplicarem a mensagem desta citação às vossas próprias vidas (ou se já estiverem a aplicá-la, analisem esse aspecto). [Dar tempo para os alunos escreverem].
2 Pergunte se alguém escolheu a primeira citação da lista. Se for o caso, peça a esse aluno que leia os seus parágrafos. (Dê autorização aos alunos para não lerem quaisquer secções que queiram manter em sigilo.) Se uma citação tiver sido escolhida por mais do que um aluno, pode da-lhes a opção de ler as respostas. Percorra todas as citações da lista assim. Prever 12 leituras de cerca de dois minutos cada.

3 Conclua a actividade com as seguintes perguntas:

- Quais são algumas das principais mensagens que podem ser tiradas destas citações?

- Quais são alguns dos benefícios pessoais positivos de que os activistas da justiça social gozam?

- Quais são alguns dos desafios e riscos?

- É importante que o cidadão comum tome medidas em relação a questões que o preocupam?

Trabalho de Casa: Arranjar uma forma de partilharem a vossa citação. Poderão discuti-la em casa com os membros da família, redigi-la com cuidado e afixá-la em algum sítio, colocá-la na vossa assinatura de email ou arranjar uma outra forma de partilharem a vossa mensagem inspiradora. Escrevam e informem amanhã como estão a partilhar a vossa citação. 


\section{citações sobre a justiça social e o activismo}

Sejam a mudança que pretendem ver no mundo.

- Mohandas Gandhi, considerado pelos indianos como pai da nação. Inspirou a desobediência civil não violenta, que conduziu à independência da Índia da Grã-Bretanha e inspirou movimentos dos direitos civis e liberdade em todo o mundo.

Lavar as mãos ao conflito entre os poderosos e os sem poder significa estar do lado dos poderosos, não ser neutro.

- Paulo Freire, um educador brasileiro influente que foi pioneiro de práticas educacionais destinadas a aumentar a consciência crítica dos pobres.

O poder não concede nada sem uma exigência. Nunca o fez e nunca o fará. Procurem saber ao que as pessoas se submeterão e saberão a quantidade exacta de injustiça e de mal que lhes será imposta; $e$ isto continuará até enfrente a resistência de palavras ou golpes, ou ambos. Os limites dos tiranos são determinados pela resistência daqueles a quem oprimem.

- Frederick Douglass nasceu escravo e tornou-se líder do movimento antiesclavagista nos Estados Unidos. Ele foi autor, orador e conselheiro do Presidente Abraham Lincoln e acreditava na igualdade universal.

A liberdade não é algo que um povo possa conceder a outro como uma oferta. O povo reivindica-a como sua e ninguém pode tirá-la de si.

- Kwame Nkrumah, fundador e primeiro presidente do Gana moderno e um Pan-africanista influente.

A responsabilidade não recai apenas sobre os dirigentes dos nossos países ou os que foram designados ou eleitos para fazer um determinado trabalho. Recai sobre cada um de nós individualmente.

- Su Santidad, el $14^{\circ}$ Dalai Lama, líder espiritual dos budistas do Tibete e activista da autonomia tibetana.

Nunca duvidem que um pequeno grupo de cidadãos preocupados e comprometidos possa mudar o mundo. Na verdade, é a única coisa que já fez.

- Margaret Mead, antropóloga cultural americana. 


\section{citações sobre a justiça social e o activismo}

O mundo é um local perigoso, não por causa dos que fazem o mal, mas por causa dos que observame não fazem nada.

- Albert Einstein, físico teórico vencedor do Prémio Nobel, mais conhecido pela teoria da relatividade. Sem rodeios contra o nazismo, foi também um activista contra os testes nucleares e o racismo.

Quando os nazis vieram para matar os comunistas, mantive-me em silêncio; eu não era comunista. Quando prenderam os social-democratas, mantive-me em silêncio; eu não era um social-democrata. Quando perseguiram os sindicalistas, não me manifestei; eu não era um sindicalista. Quando vieram para os judeus, mantive-me em silêncio; eu não era judeu. Quando me perseguiram, não havia mais ninguém para protestar.

- Martin Niemöller, famoso teólogo e pastor alemão antinazi, que foi enviado para um campo de concentração, mas sobreviveu. Continuou a ser um activista antiguerra durante toda a sua vida.

A injustiça em qualquer sítio é uma ameaça à justiça em todo o sítio. Somos apanhados numa rede inevitável de mutualidade, amarrados num único tecido do destino. O que quer que afecte uma pessoa directamente, afecta a todos indirectamente.

- Martin Luther King, Jr., ministro da igreja, foi o líder mais famoso do movimento dos direitos civis americano. Um promotor da não-violência e activista do tratamento igual de todas as raças, foi o homem mais novo agraciado com o Prémio Nobel da Paz.

São as pequenas coisas que os cidadãos fazem. É isso que fará a diferença. As minhas pequenas coisas são plantar árvores.

- Wangari Maathai, activista ambiental de género e política queniana. Ela fundou o Green Belt Movement (Movimento Cintura Verde) e recebeu o Prémio Nobel da Paz em 2004 (a primeira mulher africana a recebê-lo). Também foi Deputada do Parlamento queniano. 


\section{uma questão com que me preocupo}

VISÃO GERAL: Os alunos identificam uma questão ou problema na sociedade que seja do seu interesse. Exploram a ideia de advocacia nas suas próprias vidas.

OBJECTIVOS: Ajudar os alunos a considerar e a identificar uma questão com que se preocupam; praticar habilidades de comunicação e fala; pensar em fazer uma mudança positiva nas suas próprias vidas.

\section{INSTRUC̣ÕES}

1 Apresentar o tema:

- Aprendemos sobre várias questões que têm impacto nas nossas vidas - especialmente relativas às questões de género, saúde e direitos. Quais são algumas das questões específicas que estudámos? [Sondar os temas tratados].

- Cada um de vós deve identificar um problema social que vos preocupe. Deve estar relacionado com uma questão que tenhamos discutido.

2 Distribua a lista "Um Problema Com que Me Preocupo" a cada aluno. Explicar:

- Escrevam o vosso nome em ambas páginas desta folha. Em seguida, analisem a lista de questões de justiça social perguntando a si próprios: "Que questões me preocupam?"

- Verão que a lista está dividida em três categorias (género, saúde sexual e direitos sexuais). Assinalem três tópicos que sejam do vosso interesse. Podem ser todos da mesma categoria, ou de categorias diferentes.

- Também poderão acrescentar uma questão ligada à justiça social que vos preocupe e que não esteja na lista.

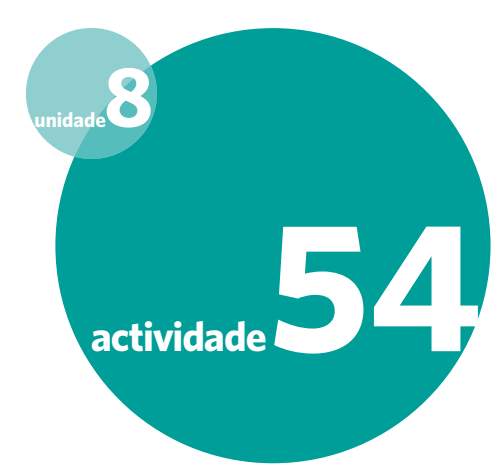

\section{DURAC̣ÃO:}

Etapas 1-4: 45 minutos

Etapas 5-8: 45 minutos

3 Coloque os alunos em pares do mesmo sexo.Explicar:

- Aos pares, têm cerca de 20 minutos para discutir uma ou mais questões do vosso interesse.

- Partilhem o que consideram que é constrangedor em relação às vossas escolhas, ou por que querem saber mais sobre elas. Talvez tenham uma história para partilhar.

- Ouçam com atenção o que os outros dizem e iniciem um diálogo respeitoso.

- Lembrem-se: Tratem todas as preocupações dos otros alunos com respeito. Justiça igual e respeito começam aqui na sala de aula com a maneira como nos comportamos perante os outros.

4 Volte a juntar o grupo e pergunte se alguém quer dizer que problema ou problemas escolheram e as razões. Dê espaço a todos os voluntários para falarem.

5 Apresente aos alunos o conceito de trabalhar em prol da mudança social (advocacia). Explicar:

- Algumas pessoas envolvem-se em grandes campanhas para mudar o mundo. Alguém já ouviu falar de acções realizadas por pessoas para resolver um dos problemas contidos na ficha técnica que vos preocupem?

\section{MATERIAL:}

Quadro + giz; uma ficha técnica ("Um Problema com que Me Preocupo") e uma ficha ("Uma Carta do Coração") para cada estudante; uma cópia da Unidade 8 de DIRECTRIZES (volume que acompanha o presente livro, também disponível em: <www. itsallone.org>).

\section{PREPARAC̄̃O:}

Rever a lista "Um Problema com que Me Preocupo". Apagar as questões que possam ser perigroso para os alunos envolver-se. Acrescentar questões relevantes localmente.

Rever a ficha "Uma Carta do Coração". Caso esteja previsto orientar os estudantes num projecto de advocacia (usando a Unidade 8 das DIRECTRIZES), manter a coluna do lado direito de "acções comuns" na ficha. Caso não, apagar essa coluna para evitar que os alunos iniciem acções de advocacia sem orientação ou apoio. 
- E de acções nas áreas que temos estado a estudar — igualdade de género e saúde, direitos sexuais e reprodutivos? [Apresentar alguns exemplos. Se for necessário, tirar um exemplo da Unidade 8 das DIRECTRIZES ou da sua própria experiência].

- Podem dar um exemplo de uma mudança que tais acções tenham trazido no mundo? [Alguns exemplos que podem mencionar são: pôr fim à prática de mutilação genital feminina, aumentar o número de raparigas na escola, homens que se juntam às campanhas contra a violência baseada no género, legalização do aborto, tornar as escolas mais seguras para os jovens homossexuais (gays) e permitir que as raparigas grávidas continuem a frequentar a escola].

6 Apresente a ideia de pequenas mudanças. Oriente uma discussão com base nos seguintes pontos:

- A advocacia muitas vezes refere-se a grandes mudanças. Mas mesmo um pequeno esforço pode causar uma mudança significativa para o melhor - nas vossas próprias vidas, ou na vida de alguém próximo.

- Imaginem e considerem uma pequena medida que podem tomar para fazer a diferença, especificamente com vista a melhorar a igualdade de género ou a proteger os vossos direitos sexuais ou reprodutivos, ou os de uma outra pessoa.

[Sondar ideias: Não discriminar uma outra pessoa, partilhar responsabilidades que normalmente são segregadas por género, decidir nunca coagir uma outra pessoa a ter relações sexuais, ou escrever um pedido de desculpa por não ter tratado alguém com respeito no passado].
- Podem lembrar-se de uma situação que tenham testemunhado na vossa própria vida em que alguém tenha feito uma mudança positiva, seja ela grande ou pequena?

7 Lembre aos alunos que existem benefícios e riscos pessoais de se envolver em advocacia. Perguntar:

- Que benefícios ou crescimento uma pessoa pode obter ao se envolver em actividades de advocacia ou em acções em prol da justiça social? [Sondar o seguinte: sentir-se com poder por saber que pode ter um impacto nos outros, criar novos relacionamentos, fortalecer habilidades pessoais, tais como falar ou escrever, admiração pelos outros].

- Que riscos uma pessoa pode enfrentar ao se envolver em acções de advocacia ou em acções de justiça social? [Sondar o seguinte: possível censura social; ser desviado do trabalho académico ou de outros aspectos importantes da vida; ficar desiludido se não conseguir as mudanças que pretende; ser preso ou enfrentar outros perigos, mesmo que as suas actividades sejam totalmente legais e não violentas. Lembrar aos alunos que é importante estar seguro].

8 (Pode ser dado como trabalho de casa.) Distribua a ficha do aluno ou escreva as perguntas nela contidas no quadro. Dizer aos alunos:

- Escrevam uma carta do coração sobre uma questão que vos preocupe e o que podem fazer sobre essa mesma questão.

- A carta pode ser-vos endereçada, ou a um pai, um amigo ou parceiro romântico ou um líder comunitário. 


\section{uma questão com que me preocupo}

A lista a seguir inclui alguns dos problemas sociais que preocupam muitas pessoas e que estão a tentar resolver. A lista centra-se em questões de três categorias: género, saúde sexual e direitos sexuais. Pensem nas questões que constituem maior preocupação para vós. Talvez se preocupem com um problema semelhante a um dos que constam na lista abaixo. Ou podem pensar numa questão totalmente diferente.

\section{Assinalar três questões que vos preocupem. Todas elas podem estar numa mesma categoria, ou em categorias diferentes.}

\section{TEMAS DE GÉNERO}

$\square$ Os nossos livros da escola reforçam os estereótipos.

$\square$ Certas políticas da nossa escola discriminam alguns grupos de pessoas.

$\square$ Existe muita provocação, arrelia e intimidação na escola.

$\square$ Os rapazes da nossa comunidade sentem-se pressionados a ser "duros" ou bravos.

$\square$ Os rapazes sentem-se pressionados a juntar-se a uma quadrilha para provarem que são homens.

$\square$ As raparigas faltam a oportunidade de aprender o que devem saber sobre o dinheiro para quando forem mais velhas.

$\square$ As raparigas faltam oportunidades suficientes para praticarem desporto ou fazerem parte das equipas.

$\square$ As raparigas não têm lugares seguros para se encontrarem com as amigas e pares.

$\square$ A publicidade retrata as pessoas do sexo masculino e feminino de uma forma que nos é prejudicial.

$\square$ Muitos jovens do sexo masculino faltam oportunidades de aprender como ser bons pais.

$\square$ A violência baseada no género (violência contra as mulheres e as raparigas) é demasiado comum e até é aceite.

$\square$ Os homens que são violentos com as suas mulheres ou filhos são geralmente mais violentos depois de consumir álcool.

$\square$ As normas de género contribuem para distúrbios alimentares.

$\square$ Demasiadas mulheres e raparigas procuram cirurgia estética para tentarem encaixar-se numa imagem ideal.

$\square$ As raparigas não têm a mesma oportunidade de ir à escola que os seus irmãos.

$\square$ As raparigas grávidas não estão autorizadas a continuar com os seus estudos.

$\square$ Os rapazes e as raparigas não são tratados da mesma maneira em casa.

$\square$ As pessoas da comunidade não entendem o suficiente sobre a desigualdade de género.

$\square$ Muito poucas pessoas estão cientes do problema de assédio sexual.

$\square$ OUTRO 


\section{uma questão com que me preocupo}

\section{QUESTÕES DE SAÚDE SEXUAL}

$\square$ Os adolescentes não têm acesso aos serviços de saúde sexual e reprodutiva amigáveis para jovens.

$\square$ É difícil obter preservativos.

$\square$ Muitos dos meus pares não sabem o que é o HIV.

$\square$ Muitas escolas na nossa zona não ensinam sobre o HIV.

$\square$ Muitas pessoas não conhecem o seu estado em relação ao HIV.

$\square$ Os jovens não têm informação básica sobre o seu próprio corpo.

$\square$ A taxa de infecções transmitidas sexualmente nos jovens é demasiado elevada.

$\square$ Muitas mulheres e raparigas em certas zonas do mundo estão em risco de sofrer de fístula obstétrica.

$\square$ As pessoas não sabem, nem se preocupam o suficiente com a mortalidade materna.

$\square O$ aborto é legalmente restringido - e em consequência disso, perigoso - em muitos lugares.

$\square$ OUTRO

\section{QUESTÕES DE DIREITO SEXUAL}

$\square$ O problema do incesto é amplamente ignorado em muitas sociedades.

$\square$ Muitas raparigas são casadas quando ainda são crianças.

$\square$ As pessoas continuam a praticar a mutilação genital feminina.

$\square$ Muitas raparigas estão a ser sexualmente exploradas por velhos ("sugar daddies").

$\square$ Muitos jovens, especialmente raparigas, são vítimas do tráfico sexual.

$\square$ A violação é demasiado comum, e até tolerada.

$\square$ As pessoas não se apercebem de que os rapazes também correm o risco de abuso sexual.

$\square$ Os homossexuais muitas vezes não são tratados com dignidade.

$\square$ Muitos jovens, especialmente raparigas, não acham que realmente têm o direito de insistir no uso do preservativo.

$\square$ As pessoas que vivem com o HIV e SIDA não obtêm apoio e respeito suficientes.

$\square$ OUTRO 


\section{uma carta do coração}

NOTA: Existem muitas maneiras de fazer uma mudança positiva. Lembrem-se: é importante começar pequeno. Também é importante escolher uma acção que seja segura e legal. Algumas acções que as pessoas realizam:

\section{Nas nossas próprias vidas}

Decidir não discriminar o próximo

Acompanhar um amigo que necessite a um centro de saúde

Prometer não se envolver em acções de violência pessoal

Ouvir alguém que necessite de falar

Saber mais sobre a questão que me preocupa

Conversar com os meus amigos e familiares

\section{No mundo em geral}

Criar um pequeno grupo de acção social

Escrever uma carta a um funcionário público

Escrever um artigo conscientizar meus pares

Juntar-me a uma organização que trabalhe na questão

Pedir que a escola mude uma política (sobre a questão)

Planificar um evento na comunidade

\section{Cara/Caro}

Estou a aprender sobre igualdade de género e sobre saúde e direitos sexuais. Creio que posso dar um passo pequeno, mas importante, para fazer uma mudança positiva. Uma questão que me preocupa é

Uma coisa que eu posso fazer para contribuir para uma mudança positiva é [escolher uma acção da lista acima, ou escrever uma ideia diferente]:

O que eu espero é

Quero ser uma pessoa que

Atenciosamente, 


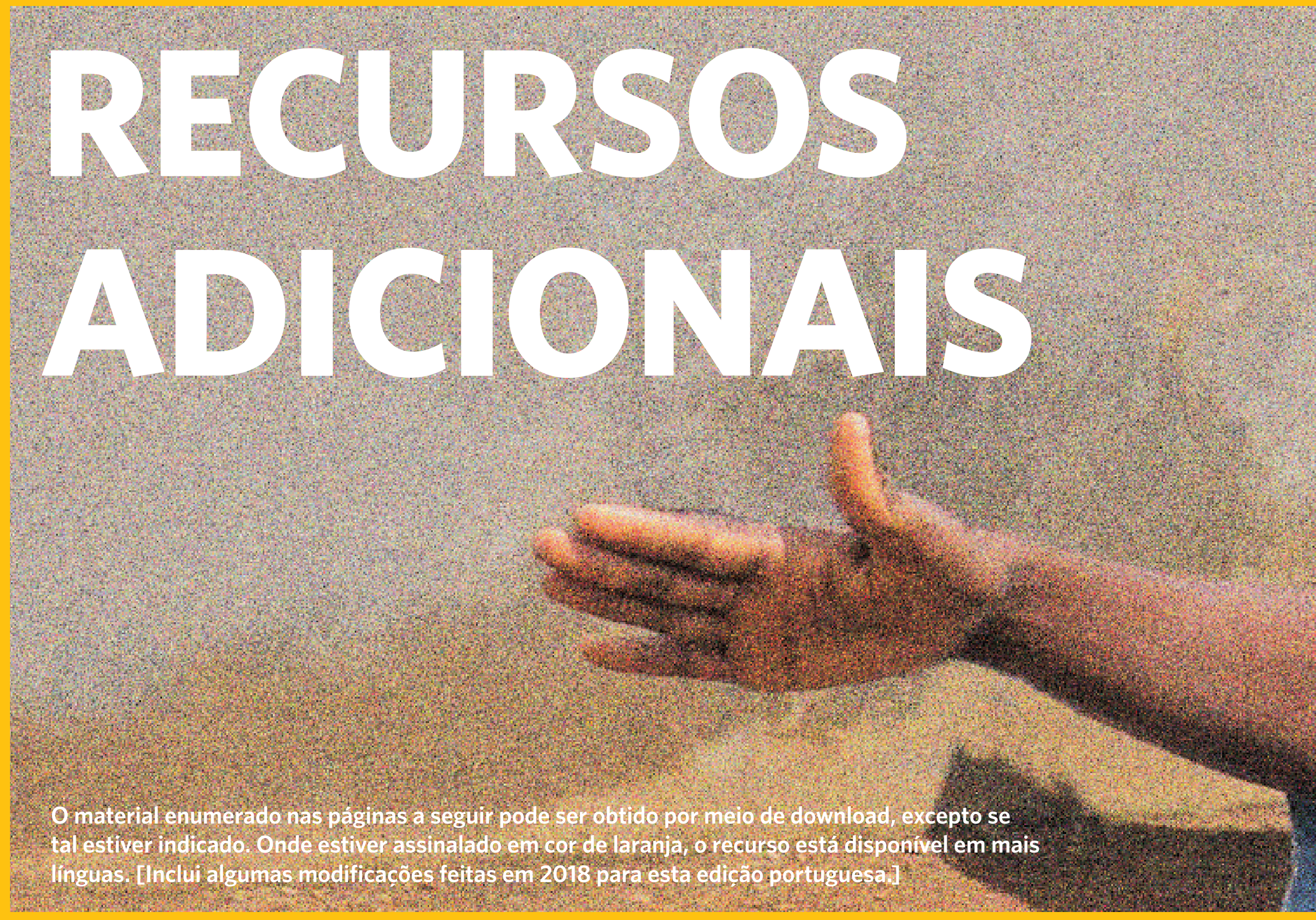




\section{exemplos de programas seleccionados}

Aahung no Paquistão, realiza acções de formação, pesquisa e advocacia com vista a criar um ambiente em que todos os direitos sexuais individuais sejam respeitados, protegidos e cumpridos. <www.aahung.org>.

Conscientizing Male Adolescents na Nigéria, teve como objectivo desenvolver uma consciência crítica dos adolescentes do sexo masculino em relação a preconceitos e práticas sexistas e as atitudes e habilidades para os mudar. Para mais informações, ver Q/C/Q questão 14: < https://xyonline.net/sites/xyonline. net/files/Popul\%20Council\%2C\%20My\%20father\%20didn\%27t.pdf>. Também disponível em francês.

Dance4Life envolve dançarinos, músicos, educadores de pares e jovens que vivem com o HIV na educação e capacitação de jovens na luta contra o HIV e SIDA. $<$ www.dance4life.com>.

Democracia y Sexualidad (DEMYSEX) é uma rede de organizações mexicanas que pretende fortalecer a educação sexual com vista a garantir a equidade de género e o exercício dos direitos sexuais no desenvolvimento de uma cultura democrática.

$<$ www.demysex.org.mx>. Também disponível em espanhol.

Girls Power Initiative na Nigéria tem em vista equipar as raparigas com

informação, habilidades e oportunidades de acção para que venham a ser mulheres jovens competentes e confiantes. <www.gpinigeria.org>.

\section{International Centre for Reproductive Health and Sexual Rights (INCRESE) na}

Nigéria, trabalha para alargar o acesso à informação e serviços de saúde e direitos sexuais. <www.increse-increse.org $>$.

MenEngage é uma aliança global que se destina a envolver homens e rapazes na redução das desigualdades de género e na promoção da saúde e bem-estar das mulheres, homens e crianças. <www.menengage.org>.
Promundo trabalha para promover a equidade de gênero e prevenir violência envolvendo homens e meninos em parceria com mulheres e meninas, desenvolvendo programas, campanhas e esforços de advocacy. Materiais, vídeos e outros recursos educacionais sao disponíveis em: < https://promundo.org.br/> Também disponível em português.

Raising Voices no Uganda, trabalha para prevenir a violência contra as mulheres, debruçando-se sobre causas como os papéis de género tradicionais e $o$ desequilíbrio de poder entre mulheres e homens. <www.raisingvoices.org>.

ReproLatina realiza diversas actividades através de ações pontuais e projetos nas áreas da Saúde Sexual e da Saúde Reprodutiva com adolescentes e jovens, profissionais de saúde, da educação e da promoção social. < http://www. reprolatina.org.br/home> Em português.

Scenarios USA (inicialmente inspirado por Scenarios do Sahel) patrocinou um concurso de programas e de redacção de argumentos com base na reflexão sobre as questões de género. Os argumentos vencedores são transformados em curtasmetragens. Muitos dos seus vídeos podem também ser vistos gratuitamente online. $<$ https://www.youtube.com/user/scenariosusa>.

Sonke Gender Justice Network trabalha com homens, mulheres, jovens e crianças da África Austral com o objectivo de alcançar a igualdade de género, prevenir a violência baseada no género e reduzir a propagação do HIV e o impacto do SIDA. <www.genderjustice.org.za>.

White Ribbon Campaign trabalha para educar homens e rapazes para porem termo à violência contra as mulheres. <www.whiteribbon.ca>. Também disponível em francês. 
ABC: Teaching Human Rights-Practical Activities for Primary and Secondary Schools, Alto Comissariado das Nações Unidas para os Direitos Humanos, 2003. 124 páginas. Este manual ajuda os educadores a criar a consciência e acção na área dos direitos humanos. <www.ohchr.org/EN/PublicationsResources/Páginas/ TrainingEducation.aspx>. Também disponível em árabe, chinês, francês, russo e espanhol.

\section{African Transformation: The Way Forward, Facilitator's Workshop Guide,} Health Communication Partnership, USAID e Communication for Development Foundation Uganda, 2005. 118 páginas. Ferramentas para a realização de workshops comunitários sobre normas de género nas nossas vidas. <www.popline. org/ics-wpd/mmc/media/PLaFr302.pdf>.

\section{Construyendo Derechos: Talleres de Conversación Para Adolescentes, FLACSO} e FNUAP, 2006. 90 páginas. Instruções para discussões orientadas sobre oito aspectos da sexualidade e direitos. <www.issuu.com/flacso.chile/docs/ construyendo_derechos/15>. Disponível apenas em espanhol.

Empowering Young Women to Lead Change: A Training Manual, World YWCA e FNUAP, 2006. 124 páginas. Para os facilitadores que pretendam capacitar as mulheres jovens para se tornarem líderes e catalisar a mudança positiva nas suas vidas e comunidades. <www.worldywca.org/world_ywca/communications/ resources/empowering_young_women_to_lead_change>. Também disponível em espanhol e francês.

\section{Engaging Boys and Men in Gender Transformation: The Group Education}

Manual, EngenderHealth e Promundo, 2008. 356 páginas. Exercícios participativos para abranger homens (e seus parceiros), explorando a socialização do género e o seu impacto na prevenção e cuidados do HIV. <www.acquireproject.org/ archive/ files/7.0_engage_men_as_partners/7.2_resources/7.2.3_tools/Group_ education_Manual_final.pdf>. Também disponível em francês.

\section{Filling the Gaps: Hard to Teach Topics in Sexuality Education, Sexuality} Information and Education Council of the United States, 1998. 193 páginas. Este manual oferece planos de aula em temas como a abstinência, alternativas à gravidez, comportamento sexual e identidade sexual. <www.siecus.org/pubs/ filling_the_gaps.pdf>.
Gendering Prevention Practices: A Practical Guide to Working with Gender in Sexual Safety and HIV/AIDS Awareness Education, Nordic Institute for Women's Studies and Gender Research, 2003. 52 páginas. Este manual pretende desenvolver a consciência de género nos jovens como meio de promover um comportamento sexual mais seguro. <www.nikk.no/filestore/Publikasjoner/Living_for_Tomorrow/ Ift_gendprevpract.pdf>.

Gender or Sex: Who Cares?, Ipas e Health and Development Networks, 2001. 96 páginas. Este recurso de formação tem como objectivo aumentar as aptidões e o conhecimento dos adolescentes e trabalhadores jovens em matéria de género e saúde reprodutiva. <www.ipas.org/Publications/Gender_or_sex_Who_cares. aspx?ht>. Também disponível em Espanhol.

Human Rights Education Series, Human Rights Resource Center, University of Minnesota, 2000. O terceiro livro desta série, constituída por seis livros, publicado pela Amnesty International e a Gay, Lesbian and Straight Education Network, focaliza na diversidade e direitos sexuais. <www1.umn.edu/humanrts/edumat>.

International Programme on Sexuality Publications, Youth Incentives. Este website inclui brochuras, fichas técnicas, planos e resumos sobre questões de advocacia. <youthincentives.org/rutgersnisso_groep/ youthincentives/ Downloads>. Também disponível em Francês.

\section{Keep the Best Change the Rest: Participatory Tools for Working with}

Communities on Gender and Sexuality, International HIV/AIDS Alliance, 2007.

96 páginas. Este kit contém actividades para ajudar os membros da comunidade a explorar como o género e a sexualidade afectam as suas vidas e identificar formas de melhorar os seus relacionamentos e proteger a sua saúde sexual. <http://pdf. usaid.gov/pdf_docs/PNADJ846.pdf>.

MediaLitKit ${ }^{\mathrm{TM}}$ Framework for K-12 Media Literacy, Center for Media Literacy, 2005. 137 páginas. Este kit inclui uma explicação do ensino da literacia para os meios de comunicação e oferece estratégias para implementar a literacia para os meios de comunicação. <www.medialit.org $>$. Biblioteca de planos de aula disponível em <www.medialit.org/reading_room/rr4_lessonplan.php>. Também disponível em espanhol.

The New 'My Changing Body.' Institute for Reproductive Health, para breve. Este programa ensina os jovens sobre a puberdade e os seus corpos em maturação, com ênfase na menstruação e fertilidade. <www.irh.org>. Também disponível em espanhol e francês. 
One Man Can Workshop Activities: Talking to Men about Gender, Domestic and Sexual Violence and HIV/AIDS, Sonke Gender Justice, 2006. 48 páginas. Este manual oferece actividades destinadas a encorajar os homens e os rapazes a reflectir sobre as suas próprias atitudes e comportamento em relação ao género, mulheres, violência doméstica e sexual, HIV/SIDA, democracia e direitos humanos. $<$ www.genderjustice.org.za/ onemancan/complete-one-man-can-toolkit/ download-the-complete-to.html>. Também disponível em afrikaans, francês, isiXhosa e isiZulu.

\section{Our Future: Sexuality and Life-skills Education for Young People, Grades 4-5,} Grades 6-7, and Grades 8-9, International AIDS Alliance. 2006 e 2007.132 páginas, 128 páginas e 150 páginas. Estes três volumes contêm informação e actividades de aprendizagem sobre a puberdade, amizade, género, sexualidade, gravidez, infecções transmitidas sexualmente, HIV, SIDA e consumo de drogas. Também oferecem ideias sobre como preparar os pais e encarregados de educação para discutir a sexualidade com os filhos. <www.aidsalliance.org/ publicationsdetails. aspx?id=211>.

\section{People's Movement for Human Rights Education (PDHRE-International)}

trabalha no desenvolvimento e avanço da educação sobre os direitos humanos. A organização publica manuais de formação e materiais de ensino sobre os direitos humanos. <www.pdhre.org>.

Rights and Desire: A Facilitator's Manual to Healthy Sexuality, Breakthrough, 2006. 106 páginas. O objectivo deste manual é gerar um diálogo positivo sobre relacionamentos, sexo e sexualidade. <www.breakthrough.tv/ images/ downloads/53/rights_and_desire.pdf>.

Sakhi Saheli - Promoting Gender Equity and Empowering Young Women: A Training Manual, CORO for Literacy, Horizons/Population Council e Instituto Promundo, 2008. 136 páginas. O manual promove a reflexão para permitir que as mulheres jovens entendam como as normas de género afectam as suas vidas e aumentam a sua vulnerabilidade ao HIV e a outros problemas de saúde reprodutiva. <www.popcouncil.org/pdfs/horizons/India_SakhiSaheli_eng.pdf>.
Sexuality and Life-skills: Participatory Activities on Sexual and Reproductive Health with Young People, International AIDS Alliance. 2008. 172 páginas.

Fornece actividades para ajudar os jovens a desenvolver o conhecimento, atitudes positivas e habilidades para crescerem e gozarem a saúde e o bem-estar sexual e reprodutivo. <www.ibe.unesco.org/fileadmin/user_upload/HIV_and_AIDS/ publications/Alliance_Sexuality_lifeskills.pdf>.

Stepping Stones: A Training Package on HIV/AIDS, Communication and Relationship Skills, ACTIONAID, 1995. 240 páginas. £11.25. Este manual de formação contém instruções para um workshop destinado a explorar as necessidades sociais, sexuais e psicológicas e a praticar diferentes formas de comportamento nos relacionamentos. <www.steppingstonesfeedback.org>. Pode ser adquirido em <www.talcuk.org/books/bs-stepping-stones.htm>.

Tools for Change: An Educator's Resource Site, Centre for Research and Education on Violence Against Women and Children, University of Western Ontario. Este website contém uma lista de recursos para a 3 $3^{a}-9$ - classes que promovem relacionamentos salutares e iguais. <www.toolsforchange.ca>.

Yaari Dosti - Young Men Redefine Masculinity, Population Council, CORO for Literacy, MAMTA e Instituto Promundo, 2006. 110 páginas. Este manual promove a equidade de género como uma estratégia para a prevenção da infecção pelo HIV. $<$ www.popcouncil.org/pdfs/horizons/yaaridostieng.pdf>. Também disponível em hindi em <www. popcouncil.org/pdfs/horizons/yaaridostihindi.pdf>.

Young Men and HIV Prevention: A Toolkit for Action, Promundo e FNUAP. 2007. Dois documentos, 115 páginas e 38 páginas. Contêm informação conceptual e prática sobre como desenhar, implementar e avaliar as actividades de prevenção do HIV e SIDA que incorporam uma perspectiva de género e envolvem jovens do sexo masculino. < https://www.unfpa.org/publications/engaging-men-and-boysgender-equality-and-health>. Também disponível em francês e espanhol. 


\section{formação e desenvolvimento de professores}

Doorways: School-Related Gender-Based Violence Prevention and Response, USAID, 2009. Este conjunto de três manuais (um do professor, um do aluno e um dos conselheiros comunitários) apoia uma parceria comunidade-escola que se destina a tornar as escolas seguras. <www.usaid.gov/our_work/cross-cutting_ programs/wid/doorways.html>.

Gender, HIV, and Human Rights: A Training Manual, UNIFEM, FNUAP, ONUSIDA, 2000. 213 páginas. Inclui formação de um dia e formação de dois dias cujo objectivo é melhorar a compreensão dos educadores em relação às dimensões de género e direitos humanos da pandemia do HIV. <www.unifem.org/resources/ item_detail.php?ProductiD=5>.

Gender or Sex: Who Cares?: Notes for Training of Trainers, Ipas, 2002. 68 páginas. Estes apontamentos permitem que facilitadores experientes orientem a formação Gender or Sex: Who Cares? (Género ou Sexo: Quem se Importa com Isso?) (ver a secção acima sobre programas). <www.ipas.org/Publications/ Gender_or_sex_Notes_for_Training_of_Trainers.aspx?ht>.Também disponível em crioulo e espanhol.

The Human Rights Education Handbook: Effective Practices for Learning, Action, and Change, the Human Rights Resource Center, University of Minnesota, 2000. Este manual orienta os educadores para que ensinem efectivamente sobre direitos humanos. <www1.umn.edu/humanrts/edumat/hreduseries/hrhandbook/toc.html>.

\section{Our Future: Preparing to Teach Sexuality and Life Skills, An Awareness Training} Manual for Teachers and Community Workers, International AIDS Alliance, 2008. 94 páginas. Prepara os educadores para ensinar o programa Our Future (O Nosso Futuro) (ver programas e actividades na secção acima). <www.aidsalliance.org/ publicationsdetails. aspx?id=293>.

ReproLatina oferece actividades e recurses para a formação de professores e de capacitadores na area de saúde sexual e reproductiva. Em portugues e espanhol. <http://www.reprolatina.org.br/nossos-servicos>

\section{Training of Trainers: Designing and Delivering Effective Human Rights}

Education, Training Manual, Equitas - International Centre for Human Rights Education, 2007. 202 páginas. Resumo de um workshop experimental de seis dias sobre como formar formadores em matéria de educação em direitos humanos.

<www.equitas.org/ englished-manuals/ ed-manuals.php>. Também disponível em russo (edição em francês para breve)

Training Trainers for Development, Centre for Development and Population Activities, 1995. 93 páginas. Este manual oferece um workshop de seis dias para ensinar técnicas de formação participativa. <www.cedpa.org/content/publication/ detail/757>. Também disponível em francês e espanhol.

\section{leituras sobre o ensino e} aprendizagem

Experiential Learning Cycles: Overview of 9 Experiential Learning Cycle Models. Este website analisa nove modelos de aprendizagem experimental e sua aplicação. <www.wilderdom.com/experiential/elc/ExperientialLearningCycle.htm>.

Gold Dust Resources, Quality Improvement Agency. Este website contém recursos, incluindo prospectos e actividades em vídeo destinados a fortalecer as habilidades e conhecimento de professores novos e experientes. <www.goldust.org.uk>

Hesperian Foundation. Publica livros e folhetos informativos sobre as causas sociais subjacentes da má saúde O livro "Health Actions for Women: Practical Strategies to Mobilize for Change" e disponível a < http://en.hesperian.org/hhg/ Health_Actions_for_Women>. Alguns materiais disponíveis em até 152 línguas.

The Learner-centered Teaching Series, Teaching Effectiveness Program, University of Oregon. Este website oferece uma série de quatro partes sobre o ensino centrado no aluno, incluindo uma visão geral, elaboração de programas, conteúdos de ensino e avaliação dos alunos. <http://tep.uoregon.edu/workshops/ teachertraining/learnercentered/learnercentered.html>.

Paulo Freire and Informal Education, Encyclopaedia of Informal Education, 2002 Esta webpage faz uma apresentação básica do trabalho de Paulo Freire e oferece referências e links adicionais. <www.infed.org/thinkers/et-freir.htm>.

Training for Transformation, Volumes 1-3, ITDG Publishing, 2002. 462 páginas. \$50. Este conjunto de três volumes de técnicas de formação inovadoras integra várias abordagens e metodologias de educação participativa, desenvolvimento organizacional e auto-suficiência comunitária. Podem ser encomendados junto à Hesperian Foundation em: <www.hesperian.org/mm5/merchant. mvc?Screen=PROD\&Store_Code $=$ HB\&Product_Code $=$ B803\&Category Code $=\mathrm{HEB}>$ 


\section{ferramentas de implementação de programas}

Canadian Guidelines for Sexual Health Education, Ministério da Saúde do Canadá, 2003. Um exemplo de como o governo aborda a educação sexual. <www. phac-aspc.gc.ca/publicat/cgshe-Idnemss/cgshe_toc.htm>. Também disponível em francês.

CARE. A CARE tem várias publicações relevantes, nomeadamente Addressing the Social Factors that Influence Sexual and Reproductive Health (Abordando os Factores Sociais que Influenciam a Saúde Sexual e Reprodutiva) e ISOFI Toolkit: Tools for Action and Learning on Gender and Sexuality (Ferramentas de Acção e Aprendizagem sobre o Género e a Sexualidade) (para ajudar o pessoal do programa a explorar questões ligadas ao género e sexualidade). <www.care.org/ careswork/whatwedo/health/srh/ publications.asp>. Também disponível em francês e espanhol.

Developing Guidelines for Comprehensive Sexuality Education, Sexuality Education and Information Council of the United States, 1999. 36 páginas. Este manual oferece aos educadores, responsáveis pela definição de políticas e activistas um guia passo-a-passo para a elaboração de directrizes para programas abrangentes de educação sexual. <www.siecus.org/pubs/guidelines/guideintl.pdf >

Dynamic Contextual Analysis of Young People's Sexual Health: A Context Specific Approach to Understanding Barriers to, and Opportunities for, Change Thomas Coram Research Unit, University of Southampton, 2006. 51 páginas. Descreve como realizar uma análise contextual dinâmica dos factores que afectam a vida sexual dos jovens como base para a programação. <www.safepassages. soton.ac.uk/pdfs/DCA2.pdf>.

Facing the Challenges of HIV, AIDS, STDs: A Gender-based Response, Royal Tropical Institute, Southern Africa AIDS Information Dissemination Service e Organização Mundial da Saúde, Amsterdão, 1995. 56 páginas. Informação e lista de verificação para os órgãos decisores e implementadores de programas sobre a incorporação do género nas políticas e programas do HIV e SIDA e outras ITS. <http://data.unaids.org/Topics/Gender/FacingChallenges_en.pdf>. Também disponível em hindi.
HIV/AIDS Education: A Gender Perspective, Tips and Tools, UNICEF, 2002. 24 páginas. Informações gerais, listas de verificação e actividades destinadas a formar educadores em contextos formais e não formais. <www.unicef.org/lifeskills/ index_14927.html> ou <www.ibe.unesco.org/AIDS/doc/UNICEF_Gender_Eng. pdf>. Também disponível em francês e espanhol.

IPPF Framework for Comprehensive Sexuality Education, International Planned Parenthood Federation, 2006. 9 páginas. Uma visão geral da educação sexual abrangente e um quadro de planificação básico para a implementação. <www. ippf.org/en/resources/Guides-toolkits/Framework+for+Comprehensive+ Sexuality+Education.htm>. Também disponível em francês e espanhol.

Key Issues in the Implementation of Programmes for Adolescent Sexual and Reproductive Health, Departamento de Saúde e Desenvolvimento da Criança e do Adolescente, Organização Mundial da Saúde, 2004. 51 páginas. Analisa questões de programação da saúde sexual e reprodutiva do adolescente. <www.who.int/ child_adolescent_health/documents/fch_cah_04_3/en/index.html>.

RHIYA (The Reproductive Health Initiative for Youth in Asia) era uma iniciativa da União Europeia e do FNUAP para os países do Sul e Sudeste Asiático que procurava melhorar a saúde sexual e reprodutiva de jovens dos 10 aos 24 anos. 0 projecto produziu uma série de estudos de caso e relatórios de implementação de programas: <www.unfpa.org/eu_partnership/rhiya>.

Synergising HIV/AIDS and Sexual and Reproductive Health and Rights - A

Manual for NGOs, AIDSNET, 2006. 22 páginas. Apresenta factos e directivas para a integração da saúde e direitos sexuais/reprodutivos e género no trabalho do HIV. $<$ www.aidsnet.dk/Default.aspx?ID=2366>.

Toolkit for Mainstreaming HIV and AIDS in the Education Sector: Guidelines for Development Cooperation Agencies, Programa Conjunto da ONU sobre o HIV/SIDA, 2008. 75 páginas. Recursos e materiais de formação. <http://unesdoc. unesco.org/images/0015/001566/156673E.pdf> 


\section{formação e assistência técnica}

Africa Regional Sexuality Resource Centre (ARSRC), com sede em Lagos, Nigéria, organiza institutos de sexualidade na região de África. <www.arsrc.org/ training/asi/background.htm>.

Creating Resources for Empowerment in Action (CREA) trabalha com a finalidade de capacitar as mulheres para que possam articular, exigir e ter acesso aos direitos humanos através de assistência técnica e formação em direitos humanos das mulheres, género e sexualidade. Com sede na Índia, a CREA realiza vários cursos anuais em todo o mundo. <http://web.creaworld.org>.

Girls Power Initiative, com sede em Calabar, Nigéria, possui um Instituto de Desenvolvimento em Género com o objectivo de sensibilizar para as questões de género, direitos e sexualidade. <www.gpinigeria.org>.

Global Youth Coalition on HIV/AIDS é uma rede liderada por jovens constituída por 4.000 jovens líderes e aliados adultos em 150 países em todo o mundo. A GYCA forma e capacita jovens líderes para incrementarem intervenções na área de HIV e SIDA entre os seus pares. <www.youthaidscoalition.org>. Também disponível em espanhol.

Instituto Promundo, com sede no Brasil, desenvolveu o Projecto $\mathrm{H}$ e o Projecto $\mathrm{M}$ para abordar questões ligadas ao género, direitos e saúde sexual com homens e mulheres jovens. Os projectos prestam assistência técnica e formação em género e educação sexual. <www.promundo.org.br>. Também disponível em português e espanhol.
International School for Humanities and Social Sciences, Universiteit van Amsterdam faz pesquisa e tem um Instituto de Verão sobre Sexualidade, Cultura e Sociedade que explora as dimensões sociais da sexualidade nas culturas. Estão disponíveis bolsas para participantes de países seleccionados. <www.ishss.uva.nl/ Summerlnstitute/index.html>.

\section{National Sexuality Resource Center, San Francisco State University tem um} Instituto de Verão sobre Sexualidade e Cultura. <http://nsrc.sfsu.edu>.

The Pleasure Project, com escritórios em Oxford, GB e Índia, oferece formação e assistência técnica a formadores e conselheiros sobre como adoptar uma abordagem sexual positiva em relação ao seu trabalho. <www.thepleasureproject.org>

Reprolatina, Com sede no Brasil, oferece acções de formação em género e saúde e direitos sexuais e reprodutivos na Bolívia, Brasil, Chile e Paraguai. <www. reprolatina.org.br>. Disponível apenas em português.

Swedish Association for Sexuality Education (RFSU) oferece assistência técnica e formação em saúde e direitos sexuais e reprodutivos dos jovens e diversidade sexual e direitos humanos. <www.rfsu.se/default_en-us.asp>. Também disponível em espanhol, francês e sueco.

Talking about Reproductive and Sexual Health Issues (TARSHI), com sede na Índia, oferece formação em sexualidade, género e direitos na região do Sul e Sudeste Asiático. <www.tarshi.net>. Também disponível em hindi. 
Action Canada for Population and Development (ACPD) promove o desenvolvimento global centrado na saúde e direitos sexuais e reprodutivos. <www.acpd.ca>.

Advocates for Youth defende políticas que permitam aos jovens tomar decisões informadas e responsáveis sobre a sua saúde sexual e reprodutiva nos Estados Unidos e em todo o mundo. <www.advocatesforyouth.org>

Amnesty International, uma organização dos direitos humanos, promove o acesso seguro das raparigas à educação através da campanha Safe Schools (Escolas Seguras). Relatório e fichas técnicas disponíveis em <www.amnesty.org/en/campaigns/stopviolence-against-women/issues/ empowerment-women/safe-schools>.

BRIDGE, Institute for Development Studies, realiza acções de advocacia em género sanando as lacunas existentes entre a teoria, as políticas e a prática com informação sobre género acessível e diversificada em papel e online. 〈www.bridge.ids.ac.uk>.

Catholics for Choice (CFC) trabalha para o avanço da ética sexual e reprodutiva com base na justiça, um compromisso em relação ao bem-estar da mulher e a capacidade moral das pessoas tomarem decisões fundamentadas sobre as suas vidas. <www. catholicsforchoice.org>.

Center for Health and Gender Equity (CHANGE) trabalha para garantir que as políticas e programas dos Estados Unidos promovam os direitos e saúde sexuais e reprodutivos. <www.genderhealth.org/index.php>.

Center for Reproductive Rights é uma organização de advocacia legal que trabalha em todo o mundo. Para publicações sobre os direitos sexuais e reprodutivos do adolescente, consultar: <www.reproductiverights.org/pdf/adolescents\%20bp_FinaL.

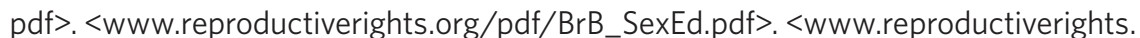
org/pdf/SexualityEducationforAdolescents.pdf>.

CHOICE for Youth and Sexuality é uma organização juvenil com sede na Holanda que promove os direitos e saúde sexuais e reprodutivos dos jovens. <www. choiceforyouth.org>.

Family Care International trabalha na prevenção de lesões e mortes relacionadas com a gravidez e o parto e para garantir os direitos e saúde sexuais e reprodutivos a nível internacional. <www.familycareintl.org/en/home>

Family Violence Prevention Fund trabalha para pôr termo à violência contra as mulheres e as crianças dentro de casa e na comunidade e para ajudar os afectados pela violência nos Estados Unidos e em todo o mundo. 〈www.endabuse.org $>$.
Human Rights Watch trabalha para proteger os direitos humanos das pessoas em todo o mundo, incluindo os direitos das mulheres; direitos das lésbicas, gays, bissexuais e transsexuais; e direitos relacionados com a saúde, incluindo o HIV. $<$ www.hrw.org>.

\section{International Gay and Lesbian Human Rights Commission (IGLHRC) trabalha} para garantir a aplicação plena dos direitos humanos por todas as pessoas, independentemente da sua orientação ou expressão sexual, identidade ou expressão de género ou estado em relação ao HIV. <www.iglhrc.org>.

International Lesbian and Gay Association (ILGA) é uma rede global de organizações empenhadas em alcançar direitos iguais para pessoas lésbicas, gays, bissexuais, transsexuais e intersexuais (LGBTI). <www.ilga.org>.

International Planned Parenthood Federation (IPPF) é uma rede global de associações membros que cuidam e fazem campanha a favor de cuidados de saúde e direitos sexuais e reprodutivos para todos. <www.ippf.org/en>.

International Women's Health Coalition (IWHC) procura produzir políticas, programas e financiamento para a saúde e população que promovam e protejam os direitos e a saúde das raparigas e mulheres em todo o mundo. <www.iwhc.org $>$.

Ipas trabalha a nível mundial para aumentar a capacidade das mulheres de exercer os seus direitos sexuais e reprodutivos e reduzir as mortes e lesões relacionadas com o aborto. <www.ipas.org>.

\section{Sexuality Information and Education Council of the United States (SIECUS)}

trabalha em prol da educação sexual e da saúde e direitos sexuais. <www.siecus.org>

Women's Global Network for Reproductive Rights (WGNRR) reúne grupos e indivíduos empenhados na advocacia dos direitos reprodutivos das mulheres. $<$ www.wgnrr.org>

World Association for Sexual Health (WAS) trabalha na promoção da saúde sexual para todos através do seu órgão internacional das suas federações continentais regionais e de organizações internacionais. <www.worldsexology.org>.

Youth Coalition, uma organização internacional de jovens, trabalha para promover os direitos sexuais e reprodutivos dos jovens a nível nacional, regional e internaciona e para garantir a participação significativa dos jovens na tomada de decisões que os afectam. <www.youthcoalition.org>.

Muitas das organizações contidas nesta página têm materiais disponíveis em várias línguas. 


\section{organizações regionais de advocacia e políticas}

Africa Regional Sexuality Resource Centre, organizado pela Action Health Incorporated na Nigéria, visa contribuir para o desenvolvimento de programas e políticas de sexualidade positiva em África através da educação, do diálogo público informado e da advocacia. <www.arsrc.org/index.htm>

Amanitare: African Partnership for the Sexual and Reproductive Health and Rights of Women and Girls trabalha na área de integridade física das mulheres e dos direitos sexuais e reprodutivos em África, defendendo a atenção para os direitos das mulheres na área do HIV/SIDA, mortalidade materna e contracepção. $<$ www.amanitare.org.za>

\section{Asian-Pacific Resource and Research Centre for Women (ARROW) promove} e protege os direitos e as necessidades de saúde das mulheres, focalizando na sexualidade e saúde reprodutiva. <www.arrow.org.my//index.php?option=com_ content\&task = view\&id=12\&itemid=29>.

\section{ASTRA - Central and Eastern European Women's Network for Sexual and} Reproductive Health and Rights, uma rede de ONG de mulheres e pessoas singulares, é defensora da saúde e direitos sexuais e reprodutivos, especialmente na Europa Central e do Leste. <www.astra.org.pl>.

European Youth Centre Budapest procura promover a unidade europeia e a dignidade dos seus cidadãos, garantindo o respeito pelos direitos humanos, a democracia pluralista e o Estado de Direito. Ver a campanha "all different, all equal" (todos diferentes, todos iguais") <www.coe.int/t/ dg4/eycb/default_en.asp> Também disponível em francês.

Latin American and Caribbean Women's Health Network (LACWHN) é uma rede de organizações e indivíduos que promovem a saúde das mulheres, direitos humanos e cidadania <www.reddesalud.org/index_en.php>. Também disponível em espanhol.

Latin American Center on Sexuality and Human Rights dissemina o conhecimento sobre a sexualidade de uma perspectiva de direitos humanos para ajudar a combater a desigualdade de género e contribuir para a luta contra a discriminação das minorias sexuais na região. <www.clam.org.br>.
National Sexuality Resource Center, San Francisco State University, desenvolve conteúdos, fornece informações e realiza acções de formação nos Estados Unidos com uma perspectiva positiva e de justiça social sobre a sexualidade http://cregs. sfsu.edu/.

SIECCAN (Sex Information and Education Council of Canada) promove a

educação pública e profissional sobre a sexualidade humana através da informação, consulta, pesquisa e publicação <www.sieccan.org/index.html>

South and Southeast Asia Resource Centre on Sexuality, organizado pela Talking About Reproductive and Sexual Health Issues (TARSHI) na Índia <www.tarshi.net> tem como objectivo aumentar o conhecimento sobre a sexualidade, saúde sexual e bem-estar sexual no Sul e Sudeste Asiático. <www.asiasrc.org/plspk/2007_1/at_ resource_centre.asp>.

Women for Women's Human Rights (WWHR), com sede na Turquia, trabalha a nível nacional e internacional para promover os direitos das mulheres. Apoia a Coalition for Sexual and Bodily Rights in Muslim Societies (Coligação pelos Direitos Sexuais e Corporais nas Sociedades Muçulmanas). <www.wwhr.org/index.php>

Women Living Under Muslim Laws (WLUML) é uma rede de solidariedade internacional que visa fortalecer o movimento pela igualdade e direitos das mulheres, cujas vidas são moldadas, condicionadas, ou reguladas por leis e costumes que se diz derivarem do islão. <www.wluml.org/english/index.shtml>

YouAct, European Youth Network for Sexual and Reproductive Health and Rights, uma rede de jovens na Europa que actua na área dos direitos sexuais e reprodutivos, tem como objectivo capacitar os jovens para fazer com que as suas vozes sejam ouvidas. <www.youact.org>.

A maioria das organizações nesta página tem materiais disponíveis em idiomas específicos à sua região. 
Advocacy Kit for Growing Up Global: The Changing Transitions to Adulthood in Developing Countries, Advocates for Youth and Population Reference Bureau, 2005. Este kit contém fichas técnicas que resumem as conclusões de uma análise de peritos da transição dos jovens para a vida adulta; também inclui dicas de advocacia. <www.advocatesforyouth.org/publications/publications-a-z/918advocacy-kit- for-growing-up-global-the-changing-transitions-to-adulthood-indeveloping- countries>. Growing Up Global pode ser comprado ou lido online: $<w w w . n a p . e d u / c a t a l o g . p h p$ ?record_id=11174>.

\section{Deadly Inertia: A Cross-country Study of Educational Responses to HIV/}

AIDS, Global Campaign for Education, Bruxelas, Bélgica, 2005. 52 páginas. Esta publicação analisa a resposta do sector da educação à pandemia do HIV. <www. comminit.com/en/node/218512/38 and www.unesco.org/bpi/aids-iatt/ deadlyinertia.pdf>.

Gender and Sexuality Cutting Edge Pack, BRIDGE, 2006 and 2007. Este pacote contém três documentos que examinam a relação entre género, sexualidade e direitos sexuais: Gender and Sexuality Overview Report (51 páginas); Supporting Resources Collection (70 páginas); e Gender and Development In Brief "Sexuality" (6 páginas). <www.bridge.ids.ac.uk/reports_gend_CEP.html\#Sexuality>.

Também disponível em francês e espanhol.

\section{HIV testing: The mutual rights and responsibilities of partners, Ruth Dixon-} Mueller e Adrienne Germain. 2007. Lancet 370(9602): 1808-1809. Este comentário defende o reconhecimento dos direitos e responsabilidades mútuos de ambos os parceiros num relacionamento ou intercâmbio sexual. <www.ph.ucla. edu/EPI/seaids/lancet370_1808_1809_2007.pdf>.

International Technical Guidance on Sexuality Education: An evidence informed approach for schools, teachers, and health educators, UNESCO, Junho de 2009 (versão preliminar). Este documento não é um programa. Pelo contrário, explica o que é a educação sexual e por que é importante. $O$ seu foco é em questões de "porquê" e "o quê" que requerem atenção em estratégias para introduzir ou fortalecer a educação sexual. <http://unesdoc.unesco.org/ images/0018/001832/183281e.pdf> Também disponível em francês e espanhol.
Ministerial Declaration-“Preventing Through Education." 2008. Esta declaração reflecte o compromisso partilhado pelos Ministros da Saúde e da Educação da América Latina e Caraíbas para fortalecer os esforços de prevenção do HIV, garantindo o acesso à educação sexual e a serviços de saúde sexual e reprodutiva abrangentes e de qualidade. Procura promover a equidade entre todos os povos e combater a discriminação. <http://data.unaids.org/pub/ BaseDocument/2008/20080801_minsterdeclaration_en.pdf>.

Também disponível em espanhol em: <http://data.unaids.org/pub/ BaseDocument/2008/20080801_minsterdeclaration_es.pdf>.

Sexuality and relationships education: Toward a social studies approach, Deborah Rogow e Nicole Haberland. 2005. Sex Education 5(4): 333-344. Este artigo argumenta que a educação sexual e sobre relacionamentos deve estar alicerçada num quadro de estudos sociais, com ênfase no género, contexto social e direitos humanos. <www.popcouncil.org/pdfs/Se_5_4.pdf>.

Também disponível em francês em <www.popcouncil.org/pdfs/Se_5_4_fr.pdf>.

Também disponível em espanhol em <www.popcouncil.org/pdfs/Se_5_4_esp.pdf>.

Triple Jeopardy: Female Adolescence, Sexual Violence and HIV/AIDS,

International Women's Health Coalition, 2008. 6 páginas. Esta nota

informativa fornece dados relevantes e uma explicação sobre a ligação entre a violência sexual e a vulnerabilidade das raparigas ao HIV; sugere respostas de políticas e programas. $<w w w$.iwhc.org/index.php?option=com content\&task=view\&id=2693\& itemid=824>. Também disponível em espanhol, francês e portugês.

Yogyakarta Principles. Este documento trata da aplicação dos direitos humanos a questões de orientação sexual e identidade de género. <www.yogyakartaprinciples. org/ index.html>. Também disponível em árabe, chinês, francês, russo e espanhol. 